\title{
Dietary proteins and energy balance
}

Citation for published version (APA):

Veldhorst, M. A. B. (2009). Dietary proteins and energy balance. [Doctoral Thesis, Maastricht University]. Datawyse / Universitaire Pers Maastricht. https://doi.org/10.26481/dis.20091030mv

Document status and date:

Published: 01/01/2009

DOI:

10.26481/dis.20091030mv

Document Version:

Publisher's PDF, also known as Version of record

\section{Please check the document version of this publication:}

- A submitted manuscript is the version of the article upon submission and before peer-review. There can be important differences between the submitted version and the official published version of record.

People interested in the research are advised to contact the author for the final version of the publication, or visit the DOI to the publisher's website.

- The final author version and the galley proof are versions of the publication after peer review.

- The final published version features the final layout of the paper including the volume, issue and page numbers.

Link to publication

\footnotetext{
General rights rights.

- You may freely distribute the URL identifying the publication in the public portal. please follow below link for the End User Agreement:

www.umlib.nl/taverne-license

Take down policy

If you believe that this document breaches copyright please contact us at:

repository@maastrichtuniversity.nl

providing details and we will investigate your claim.
}

Copyright and moral rights for the publications made accessible in the public portal are retained by the authors and/or other copyright owners and it is a condition of accessing publications that users recognise and abide by the legal requirements associated with these

- Users may download and print one copy of any publication from the public portal for the purpose of private study or research.

- You may not further distribute the material or use it for any profit-making activity or commercial gain

If the publication is distributed under the terms of Article $25 \mathrm{fa}$ of the Dutch Copyright Act, indicated by the "Taverne" license above, 
Dietary proteins and energy balance 


\section{itution}

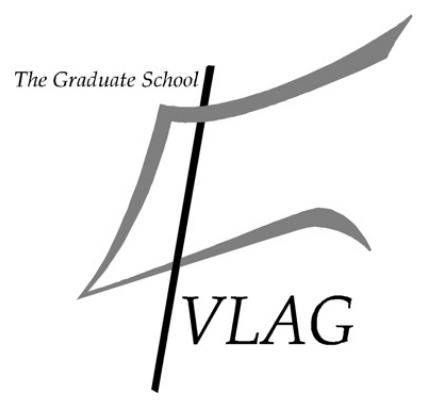

The studies presented in this thesis were performed at the Nutrition and Toxicology Research Institute Maastricht (NUTRIM), which participates in the graduate school VLAG (Food Technology, Agrobiotechnology, Nutrition and Health Sciences), accredited by the Royal Netherlands Academy of Arts and Sciences.

Cover design: Margriet Veldhorst and Datawyse

Layout:

Margriet Veldhorst

Printed by:

Datawyse, Universitaire Pers Maastricht

(C) Margriet Veldhorst, Maastricht 2009

ISBN 9789052788654 


\title{
Dietary proteins and energy balance
}

\author{
PROEFSCHRIFT
}

ter verkrijging van de graad van doctor

aan de Universiteit Maastricht

op gezag van de Rector Magnificus

Prof. mr. G.P.M.F. Mols

volgens het besluit van het College van Decanen

in het openbaar te verdedigen

op vrijdag 30 oktober 2009 om 12.00 uur

door

Margaretha Adeleida Bernadette Veldhorst

Geboren te Boekel op 26 september 1981

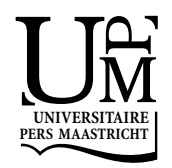




\section{PROMOTOREN}

Prof. dr. M.S. Westerterp-Plantenga

Prof. dr. K.R. Westerterp

\section{BEOORDELINGSCOMMISSIE}

Prof. dr. ir. A.M.W.J. Schols (voorzitter)

Prof. dr. J.B. van Goudoever (Erasmus Medisch Centrum/Sophia Rotterdam)

Prof. dr. W.H. Lamers

Prof. dr. A.A.M. Masclee

Prof. dr. D. Tomé (Institut National Agronomique Paris-Grignon, France)

The research described in this thesis was funded by the Top Institute Food and Nutrition. 


\section{CONTENTS}

\section{Chapter 1}

Introduction

\section{Chapter 2}

Protein-induced satiety: Effects and mechanisms of different proteins

\section{Chapter 3}

Comparison of the effects of a high- and normal-casein breakfast on satiety, 'satiety' hormones, plasma amino acids and subsequent energy intake

\section{Chapter 4}

Effects of high and normal soyprotein breakfasts on satiety and subsequent energy intake, including amino acid and 'satiety' hormone responses

\section{Chapter 5}

Effects of complete whey-protein breakfasts versus whey without GMP breakfasts on energy intake and satiety

\section{Chapter 6}

Dose-dependent satiating effect of whey relative to casein or soy

\section{Chapter 7}

A breakfast with alpha-lactalbumin, gelatin, or gelatin+TRP lowers energy intake at lunch compared with a breakfast with casein, soy, whey, or whey-GMP

\section{Chapter 8}

Protein-induced appetite suppression is affected by the presence or absence of carbohydrates

\section{Chapter 9}

Gluconeogenesis and energy expenditure after a high protein, carbohydrate-free diet

\section{Chapter 10}

General discussion

$$
\text { Summary }
$$

Samenvatting

Dankwoord 

Chapter 1

Introduction 

Overweight and obesity have become a major health problem, especially because of related comorbidities such as cardiovascular disease, diabetes type 2, and certain types of cancer (1). Several types of diets have focused on favorable macronutrient compositions in order to affect metabolic targets that may support body weight loss (2). For instance, low fat diets with moderate protein content and a relatively high carbohydrate content have been advocated for weight loss for many years (3). These diets are primarily based on the lower energy density and the prevention of overeating, as fat enhances the flavor and palatability of a meal $(2,3)$. After the initial interest for low fat diets, diets with low carbohydrate content have been popularized, mainly by Dr. Atkins, and have been shown to induce a rapid weight loss (3). Related to these low carbohydrate diets are the diets with a low glycemic index and a high fiber content. These diets may enhance weight control since they are associated with increased satiety and are suggested to reduce the risk of cardiovascular disease and diabetes (4). The last decade numerous studies have been published on the effects of high protein diets on body weight loss. Results indicate that high protein diets may decrease body weight more compared with control diets in overweight or obese subjects and improve weight maintenance after weight loss (5-9). Additionally, the chances for weight regain are smaller at a high protein diet compared with a normal protein diet due to higher energy costs for weight gain (10).

Conditions for successful weight maintenance after weight loss are 1) sustained satiety despite a negative energy balance, 2) sustained basal energy expenditure despite a negative energy balance, and 3) sparing of fat-free body mass (8). A relatively high protein intake while in negative energy balance (weight loss) or in energy balance after weight loss (weight maintenance) has been shown to affect these metabolic targets, hence, relatively high protein diets appear to increase postprandial and post-absorptive satiety and elevate thermogenesis (69). Moreover, energy efficiency is lower with high protein diets, i.e. the energy costs for weight gain are higher at a high protein diet compared with a normal protein diet (10). Thus, the effectiveness of diets with a relatively high protein content for body weight loss and weight maintenance can be explained by the observation that these diets favorably affect both sides of the energy balance, i.e. suppression of appetite and thereby reduction of energy intake and stimulation of energy expenditure.

The metabolism of proteins in the body affects control of food intake and energy expenditure in various ways. The work presented and discussed in this thesis relates to the effects of dietary proteins, in the presence or absence of carbohydrates, on energy intake as well as on energy expenditure. It addresses the question whether the increased satiety after high protein meals also holds for specific types of protein and whether there are differences in satiety between different types of protein. Furthermore, the effects of the presence or absence of a normal proportion of carbohydrates in a high protein diet on appetite and energy expenditure are evaluated and it is studied whether increased energy expenditure after a high protein diet may be attributable to gluconeogenesis. In the present chapter some general aspects of dietary protein and protein metabolism are presented, followed by a brief overview of the control of food intake and the way this is affected by proteins. Accordingly, possible effects of protein intake on energy expenditure are discussed and finally the studies that are presented in this thesis are introduced. 


\section{DIETARY PROTEINS}

Protein is one of the three macronutrients and plays a role in virtually all biological processes. After digestion and absorption it is incorporated in body proteins like muscles, enzymes, or peptide hormones and serves as an energy source. The recommended daily protein intake is 10 to $15 \%$ of energy or $0.8 \mathrm{~g}$ protein per kg body weight for healthy adults in energy balance $(1,11$, 12). In the Netherlands protein is mainly derived from meat, dairy-, and cereal-products and intake is with on average $81 \mathrm{~g}$ protein per day (14\% of energy) according to the recommendations (13). A protein intake between 10 and $15 \%$ of energy can be considered as normal, whereas an intake above $15 \%$ of energy can be regarded as high protein intake. However, the interpretation of what is a high protein intake is strongly related to energy balance, i.e. energy intake. Relatively high protein diets for weight loss and weight maintenance consist of $25-45 \%$ of energy from protein. When expressed as percentage energy from protein these diets are relatively high in protein, however, in absolute terms (gram of protein) they contain a sufficient absolute amount of protein and less energy in total $(14,15)$.

Proteins are polymers of amino acids: molecules with a carboxyl-carbon group and an amino- $\mathrm{N}$ group attached to a central carbon. They differ in structure by the substitution of one of the two hydrogens on the central carbon with another functional group (16). Of the 20 amino acids that can be incorporated directly in mammalian protein, some are synthesized de novo from other amino acids or precursors; these are the non-essential or dispensable amino acids. No pathways exist for the synthesis of nine other amino acids (histidine, isoleucine, leucine, lysine, methionine, phenylalanine, threonine, tryptophan, and valine), hence these are essential or indispensable and have to be derived from the diet (17). The quality of dietary protein is related to the ability to achieve nitrogen and amino acid requirements for tissue growth and maintenance. This ability depends both on the content of essential amino acids and on the digestibility of the protein and subsequent metabolism of the absorbed amino acids $(12,18)$.

\section{Protein metabolism}

After ingestion protein is metabolized immediately; among the macronutrients protein is unique in that there is no storage form that is not already serving another purpose. Whereas carbohydrates and fat are stored in the body as glycogen and triglycerides, respectively, for later use as fuels, all proteins in the body are built into tissues or compounds like enzymes or hormones that have vital roles. Proteins are catabolized when additional fuel is needed whereas previously sacrificed proteins are replaced during periods of energy and nitrogen excess. Protein metabolism thus involves a continuous breakdown and (re)synthesis of protein, i.e. protein turnover, that involves $3-4 \%$ of whole body protein per day and mainly takes place in the splanchnic region (gut and liver) and skeletal muscle $(17,19,20)$. The rate of protein turnover of individual proteins is different and tends to follow their function in the body: those proteins whose concentrations need to be regulated or which act as signals (enzymes, peptide hormones) have a high turnover whereas structural proteins (collagen, myofibrilar proteins) have relatively long lifetimes (17). The body contains on average between 10 and $12 \mathrm{~kg}$ of protein, with the largest quantity ( 6 to $8 \mathrm{~kg}$ ) located within skeletal muscle and approximately $210 \mathrm{~g}$ of amino acids that exist in free form $(17,19-21)$. Amino acids thus are supplied from ingested proteins or 
from de novo synthesis of non-essential amino acids. Degradation of amino acids involves oxidation, excretion or conversion to other metabolites and serves two purposes: 1) production of energy from oxidation, or 2) conversion into other products, e.g. neurotransmitters, creatine, purines, and pyrimidines. Complete amino acid degradation ends up with the production of nitrogen, which is removed by incorporation into urea, whereas the carbon skeletons are oxidized as $\mathrm{CO}_{2}$ via the tricarboxylic acid cycle or are used for the formation of fat and carbohydrates $(17,20)$.

The rates of protein synthesis and breakdown are closely regulated by multiple hormonal and nutritional factors and are affected by physiological conditions such as fasting, feeding, exercise, disease, and aging (22). Insulin, growth hormone, insulin-like growth factor 1, adrenalin, and androgens have an anabolic effect on protein balance whereas cortisol, glucagon, and thyroid hormones have a catabolic effect (23). Many diseases have a catabolic effect, they decrease protein synthesis and/or enhance protein breakdown (22). Exercise increases protein breakdown whereas protein synthesis is suppressed. However, after exercise protein synthesis is stimulated and breakdown remains elevated; a positive nitrogen balance is achieved only when amino acid availability is increased (24). In addition, aging has a significant effect on protein metabolism. The rate of protein turnover is high in the early stages of life but declines markedly during the first years, little further change occurs during adult years (25). Nevertheless, later in life it declines, as a result elderly have a lower protein turnover than young adults (26). With fasting, the initial response of protein turnover is a reduction in the rate of protein synthesis that is accompanied by a decrease in protein breakdown. With prolonged fasting ( $>2$ days) the rate of protein breakdown increases to provide energy via degradation of amino acids $(17,20)$. Although fasting has a significant effect on protein turnover, responses to more subtle changes in energy intake are rather small. Contrarily, protein intake has a large effect on protein turnover (27).

Dietary protein affects protein turnover at two levels: there is an immediate response to the intake of protein in meals and there is a longer term adaptation to a change in protein intake (27). The acute effect of protein intake on protein turnover is a depression of whole-body protein breakdown, whereas the effect on protein synthesis is equivocal but seems to be less (27-30). The adaptation to the higher protein intake thus is mainly achieved via changes in amino acid oxidation, especially when protein intake is above requirements (25). Nevertheless, after exercise muscle protein synthesis can be further increased by ingestion of amino acids (31, 32). The longer term adaptation to higher protein intake involves increases in both synthesis and breakdown rates in the post-absorptive state, i.e. an elevation of the basal rate of protein turnover. The acute response to food intake, which is larger with high protein diets, is superimposed on this. Protein breakdown starts at a higher basal level but is depressed more by the high protein meal. Protein synthesis also starts at a higher rate and is unaltered or slightly stimulated by feeding. Therefore, the rate of protein synthesis in the fed state is higher when the diet is high in protein. In addition, there are analogous changes in amino acid oxidation involving both acute effects of feeding and adaptations to longer term changes in protein intake $(26,27,33)$. In addition, protein turnover can be affected by the type of protein: after two weeks of a high protein diet protein breakdown was less inhibited by vegetable protein than by animal protein (34). The continuous breakdown and (re)synthesis of proteins that are originally derived 
from dietary protein affects several processes in the body, including the regulation of appetite and food intake.

\section{APPETITE AND FOOD INTAKE}

A hierarchy in the satiating efficacies of the macronutrients has been observed, with protein being the most satiating and fat the least $(6,35,36)$. Moreover, meals higher in protein increase postprandial and post-absorptive satiety more than meals lower in protein acutely as well as after one or more days of a high protein diet $(7,36-39)$. Satiety refers to the inhibition of hunger and further eating after food consumption which affects the inter-meal interval (40). Whether satiation, i.e. suppression of hunger and appetite within a meal that determines meal termination, is affected by dietary protein is less known and may depend on the type of protein $(7,8,40)$. From animal studies it is known that dietary protein is involved in the control of food intake and that differences between types of protein may occur. Pigs and rats are capable of selecting the protein:energy ratio that is optimal for growth (41-43). Imbalances in single essential amino acids can greatly affect feeding behavior in rats; animals reject diets that lead to depletion or deficiency of essential amino acids. This suggests that the kind of amino acids ingested may influence satiety $(43,44)$.

Effects on appetite in humans can be measured by assessing actual food intake. Moreover, sensations of hunger, satiety, fullness, and desire to eat can be measured using $100 \mathrm{~mm}$ Visual Analogue Scales (VAS). When used appropriately, these subjective appetite ratings are reproducible and sensitive and can predict food intake to a certain extent (45-47). Appetite is affected by a cascade of processes, which in turn are controlled by many central and peripheral factors. Satiation is mainly determined by sensory processes whereas satiety is affected by cognitive, post-ingestive, and post-absorptive processes (40).

\section{Control of food intake}

The caudal brainstem, hypothalamus, and parts of the cortex and limbic system are the main brain regions involved in the control of food intake (48). In the caudal brain stem sensory information from the gastrointestinal tract and taste information from the oral cavity are integrated. These signals are initiated by mechanical or chemical stimulation of the gastrointestinal tract and are transmitted through the nervus vagus to the nucleus of the solitary tract in the brain stem (49). Signals are further transmitted to the arcuate nucleus of the hypothalamus where information from the periphery and from other brain regions is integrated. For instance, information from the cortico-limbic systems that process signals regarding learning, memory, and reward is integrated (48). The arcuate nucleus includes two opposing neuronal circuits: an appetite-stimulating (orexigenic) and an appetite-inhibiting (anorexigenic) circuit. The orexigenic circuit produces the neurotransmitters neuropeptide Y (NPY) and agoutirelated peptide (AgRP). In the anorexigenic circuit the neurotransmitters cocaine- and amphetamine-regulated transcript (CART) and pro-opiomelanocortin (POMC), which produces $\alpha$ melanocyte-stimulating hormone $(\alpha-M S H)$, are expressed. When one of these circuits is activated, the other is inhibited (49-52). The major projection sites of the neurons of the arcuate nucleus are the lateral hypothalamic area and the paraventricular nucleus of the hypothalamus. 
These two brain regions contain neuropeptide-expressing neurons associated with control of food intake (48).

The peripheral post-ingestive and post-absorptive signals that the brain receives originate from the body energy reserves, i.e. insulin and leptin $(51,53)$, or are hormonal and neural signals from the gastrointestinal tract, including a variety of gut peptides. The interaction of nutrients with specific receptors in the small intestine after a meal stimulates the release of anorexigenic hormones, such as cholecystokinin (CCK), glucagon-like peptide 1 (GLP-1), peptide YY (PYY), and insulin into the circulation $(51,54-57)$. Ghrelin is synthesized in the stomach and circulating concentrations have been shown to increase before meals and decrease with feeding. Therefore, ghrelin is considered as an orexigenic hormone (58). The gastrointestinal hormones have been shown to affect appetite sensations and energy intake in humans $(51,54-56,58,59)$. Proteins seem to affect peripheral and central processes that control food intake, as is described in the following section.

\section{Protein-induced satiety}

First of all, proteins are thought to have a low palatability that varies according to the type of protein and may affect appetite (60). In addition, proteins are likely to generate signals while still in the digestive tract. Chemoreceptors that are able to detect the presence of peptides and amino acids trigger the release of hormones such as CCK, GLP-1, or PYY; variations in concentrations of these hormones are directly recorded by the central nervous system $(60,61)$. Among the post-absorptive metabolic factors, increased thermogenesis that produces direct and indirect signals recorded by the central nervous system may be another mechanism for proteininduced satiety (60). Proteins have been shown to induce a greater thermogenic effect than the other macronutrients and this has been shown to be related to an increased satiety $(38,62,63)$. The theoretical basis for this relationship may be that increased energy expenditure at rest implies increased oxygen consumption and an increase in body temperature that may lead to a feeling of deprived oxygen and thus promote satiety. This is in line with the higher satiety that was observed under limited oxygen availability at high altitude or in patients with chronic obstructive pulmonary disease $(36,64)$. Another post-absorptive metabolic factor that induces satiety at a high protein intake may be increased amino acid-induced gluconeogenesis which prevents a decrease in blood glucose concentration. Modulation of glucose homeostasis and glucose signaling to the brain via gluconeogenesis may be involved in the satiating effect of protein $(60,61,65,66)$. Finally, it has been suggested by Mellinkoff that an elevated concentration of plasma amino acids which can not be channeled into protein synthesis, may serve as a satiety signal for a food intake regulating mechanism. Once amino acid concentrations reach a certain point this is recorded by the brain and appetite is suppressed, resulting in decreased food intake (67). Recording of variations in free amino acid concentrations by the central nervous system could involve a central nutrient chemosensor system for essential amino acids, or other specific mechanisms associated with central availability of specific amino acid precursors of certain neurotransmitters (60).

Several brain areas have been identified to be involved in the transfer of information regarding ingested protein. The nucleus of the solitary tract integrates sensory information and its neuron activity is increased by intraduodenal amino acids. Signals circulating in the blood that are 
related to protein ingestion, e.g. amino acids, peptides, and hormones, have different targets in the brain, including the area postrema, anterior piriform cortex, and the arcuate nucleus $(49,60$, 68). Other hypothalamic regions such as the paraventricular nucleus and the lateral and ventromedial hypothalamus are also involved. However, the way in which the information arising from protein ingestion leads to the control of food intake still is incompletely understood $(60,68)$.

\section{Type of protein}

Although high protein meals have been shown to be more satiating than normal protein meals, it is not known whether the higher satiety after high protein also holds for specific types of protein. Moreover, there are suggestions that different types of protein affect satiety differently (69-74). Since characteristics like amino acid composition and digestion rate differ among different proteins, the post-ingestive and post-absorptive responses may be different and may contribute to differences in satiating efficacies. Possible differences in satiating efficacies between concentrations of the same type of protein or between different types of protein may be attributable to different responses of one or more (an)orexigenic hormones or changes in amino acid concentrations $(38,70,71,75)$.

Casein is considered as a 'slow' protein because it coagulates in the stomach and delays gastric emptying, resulting in smaller but prolonged elevated postprandial amino acid concentrations $(76,77)$. Whey on the other hand is considered as a relatively 'fast' protein, that is thought to induce satiety quickly $(71,76-78)$. Two types of whey-protein are often used: whey with glycomacropeptide (GMP) and whey where GMP is removed. Although equivocal, there are some suggestions that GMP contributes to the satiating effects of whey (79-81). Soy is a high quality vegetable protein that contains all essential amino acids and is often used in food products, which makes it of interest to compare the satiating efficacies of soy with other types of protein (82). The amino acid tryptophan (TRP) is one of the large neutral amino acids (LNAA) and may act as a precursor for the neurotransmitter serotonin, which is suggested to be involved in appetite regulation (83). This is supported by the anorexigenic effects of serotonergic drugs in human subjects $(84,85)$. The protein alpha-lactalbumin contains high levels of TRP and has been suggested to increase brain serotonin production and thereby to affect appetite (86). Gelatin is a protein that does not contain the essential amino acid TRP, moreover, the oxidation of gelatin is calculated to be highly inefficient causing a high thermogenesis, which could affect satiety $(36,38)$. In order to reveal whether TRP content contributes to a possible difference in satiating efficacies of gelatin and alpha-lactalbumin, TRP can be added to gelatin and this 'type of protein' can be compared with alpha-lactalbumin and gelatin. It is yet unknown whether there are differences in satiating efficacies between the afore mentioned types of protein.

When satiating efficacies of one type of protein in different concentrations or between different types of protein at the same concentration are compared, it is important to actually use pure proteins in a realistic meal setting, i.e. in the presence of carbohydrates and fat. In order to preclude effects on sensory, post-ingestive, or post-absorptive processes that are not due to protein type or protein concentration per se, meals have to be standardized on aspects like taste, viscosity, and energy density (87-89). To ascertain that test meals are the same with 
respect to all these items, food technologists should be involved in product development and meals should be tested by a taste panel.

In order to accurately measure the effect of an earlier meal on subsequent energy intake, timing of the ad libitum meal is of major importance. On the one hand, an ad libitum meal should not be offered too soon for satiating efficacies to be fully developed or to be a realistic moment. On the other hand, it should be prevented that differences in appetite ratings or concentrations of (an)orexigenic hormones or amino acids have become extinguished over time. The sensitive moment for an ad libitum meal, i.e. the moment in time that may be sensitive to show a possible difference in food intake, should therefore be carefully determined (74). The sensitive moment can be assessed by first measuring changes in appetite ratings and concentrations of hormones and/or amino acids up to 4-5 hours after consumption of a test meal and a control. The latest moment where there are differences in appetite ratings and/or hormone or amino acid concentrations between the two meals may be considered as the sensitive moment to offer an ad libitum meal in a subsequent experiment.

To summarize, protein intake affects the control of food intake on various ways and differences in satiating efficacies between concentrations and types of protein may exist.

\section{ENERGY EXPENDITURE}

Apart from its effects on appetite and energy intake, protein intake affects energy expenditure as well. Total energy expenditure (TEE) or average daily metabolic rate (ADMR) consists of four components: sleeping metabolic rate (SMR), energy costs of arousal, diet-induced thermogenesis (DIT), and activity-induced energy expenditure (AEE). The SMR and the energy costs of arousal together form the basal metabolic rate (BMR) or resting energy expenditure, i.e. the energy expenditure of an awake, resting subject in the post-absorptive state in a thermoneutral environment (90). BMR is on average 5\% above SMR and accounts for $60-80 \%$ of daily energy expenditure. It is closely related to the amount of metabolically active cell mass, i.e. fat free mass, and can be estimated based on gender, age, height, and body weight using predictive equations such as the equation of Harris and Benedict (90-92). The continuous turnover of the body protein pool accounts for on average $20 \%$ of BMR, this may vary due to differences in muscle mass $(93,94)$. DIT is the increase in resting energy expenditure due to the processing, i.e. digestion, absorption, and conversion of food. A mixed diet consumed in energy balance results in a DIT of on average $10 \%$ of TEE, however, values are higher with relatively high protein consumption $(90,95)$. AEE is the most variable component of TEE and can be determined by subtracting BMR and DIT from TEE. The level of physical activity (PAL, physical activity level) is often expressed as TEE or ADMR divided by BMR and ranges between 1.2 and 2.5 for sustainable lifestyles. As a fraction of ADMR, AEE varies from $5 \%$ in a subject with a minimum PAL of 1.2 to $50 \%$ in a subject with a PAL of 2.5 , on average AEE is one third of ADMR $(90,96)$.

Consumption of relatively high protein meals or diets has been shown to increase energy expenditure, via an increase in DIT and/or an increase in SMR or BMR $(36,38,62,63,97,98)$. The mechanism behind a higher energy expenditure after a high protein diet may be that the body has no storage capacity to cope with high protein intake and therefore has to metabolize it 
immediately (99). Since peptide-bond synthesis has high ATP costs, increased protein synthesis may contribute for a large part to the increased energy expenditure (99-101). Indeed, energy expenditure was found to be positively correlated with amino acid concentration and amino acid-induced protein synthesis (102). In addition to the high energy costs of protein synthesis, increased energy expenditure at a high protein diet may be partially attributed to increased rates of ureagenesis $(100,101)$. Since there are large differences in the efficacy with which amino acids are oxidized, the amino acid composition of the protein may be an important determinant of the metabolic efficacy of protein oxidation. This is dependent on the variety of carbon chains and cofactors that are involved in amino acid catabolism. Taking into account the differences in amino acid catabolism and urea synthesis between different amino acids, the calculated energy expenditure to produce ATP is ranging from $99 \mathrm{~kJ} /$ ATP for glutamate to 153 kJ/ATP for cysteine. Compared with glucose and fatty acids, which have a metabolic efficacy of $91 \mathrm{~kJ} /$ ATP and $96 \mathrm{~kJ} /$ ATP respectively, the metabolic efficacy of amino acid oxidation is relatively low (101) and this may contribute to a higher energy expenditure after a high protein meal. Another pathway of increased energy expenditure may be via an up-regulation of uncoupling proteins. In animal models, increased protein intake increases uncoupling protein-2 in liver and uncoupling protein-1 in brown adipose tissue. These changes are positively correlated with energy expenditure $(99,103)$. In addition to the afore mentioned processes, gluconeogenesis may also contribute to increased energy expenditure at a high protein diet $(99,100)$.

\section{Gluconeogenesis}

Gluconeogenesis is the formation of glucose from non-carbohydrate precursors including amino acids, glycerol, lactate, pyruvate, and intermediates from the tricarboxylic acid cycle. Of these metabolites, net glucose formation only occurs from amino acids and glycerol (104). A relatively narrow range of circulating glucose is necessary for good health, since a too low glucose concentration reduces glucose availability as a fuel for the brain whereas too high glucose concentrations could be toxic (105). In the overnight, post-absorptive state, circulating glucose is derived from endogenous glucose production that consists of two processes: gluconeogenesis and glycogenolysis, i.e. the release of glucose from stored glycogen, which contribute equally to total glucose production. In the fed state, circulating glucose is derived from dietary glucose and, dependent on the diet, from gluconeogenic substrates whereas glycogenolysis is reduced (106, 107). The rate of gluconeogenesis is controlled by the supply of gluconeogenic substrates or its end-product (108). The supply of substrates can be altered by hormones: glucagon and catecholamines exert a rapid, direct stimulatory effect whereas insulin has an inhibitory effect. Glucocorticoids, e.g. cortisol, are permissive for the stimulation of amino acid transport by glucagon or catecholamines $(108,109)$.

Gluconeogenesis is a pathway for dietary protein to be metabolized immediately. In rats, gluconeogenesis has been shown to be stimulated by a high protein diet $(110,111)$. When increasing the protein content of the diet in rats, the activity of the enzymes phosphoenolpyruvate carboxykinase and glucose 6-phosphatase changed in such a direction that liver gluconeogenesis was stimulated (65). Calculations from a theoretical perspective have shown that gluconeogenesis involves a loss of about $20 \%$ of the energy when compared to direct uptake and oxidation of glucose. The removal of nitrogen and conversion of the carbon skeletal 
to glucose has high energy costs and it is estimated that about $20 \%$ of the energy content of glucose has to be expended to produce it through gluconeogenesis $(112,113)$. Therefore, gluconeogenesis can be considered as an energetically costly pathway of protein metabolism. If gluconeogenesis indeed is increased in humans who are on a high protein diet, it may significantly contribute to the increased energy expenditure after such a diet $(7,98-100,112)$.

For gluconeogenesis, the carbon skeletons of amino acids can be converted into seven molecules: pyruvate, acetyl CoA, acetoacetyl CoA, $\alpha$-ketoglutarate, succinyl CoA, fumarate, and oxaloacetate. Amino acids that are degraded to acetyl CoA or acetoacetyl CoA are termed ketogenic: the other amino acids are considered as glucogenic amino acids. Only leucine and lysine are solely ketogenic; isoleucine, phenylalanine, tryptophan, and tyrosine are both ketogenic and glucogenic. Thus, amino acids enter the pathway of gluconeogenesis as pyruvate or oxaloacetate and are, via phospho-enolpyruvate and glyceraldehyde-3-phosphate, converted to glucose (figure 1). In addition, the other gluconeogenic substrates, glycerol and lactate, enter the pathway as di-hydroxyacetonephosphate and pyruvate, respectively. The major enzymes that control gluconeogenesis are pyruvate carboxylase, phosphoenolpyruvate carboxylase, fructose 1,6-biphosphatase, and glucose 6-phosphatase (16).

Fractional gluconeogenesis, i.e. the relative contribution of gluconeogenesis to total endogenous glucose production, can be measured using stable isotope techniques. In the pathway of gluconeogenesis, $\mathrm{H}_{2} \mathrm{O}$ is incorporated into the precursors of glucose (figure 1 ) and after ingestion of ${ }^{2} \mathrm{H}_{2} \mathrm{O}$ part of the glucose that has been produced will contain ${ }^{2} \mathrm{H}$ instead of $\mathrm{H}$. Glucose produced through gluconeogenesis will be labeled with ${ }^{2} \mathrm{H}$ at the $\mathrm{C} 2$ and $\mathrm{C} 5$ position of glucose whereas glucose produced through glycogenolysis will be labeled with ${ }^{2} \mathrm{H}$ at the $\mathrm{C} 2$ position of glucose. The ratio of enrichment of ${ }^{2} \mathrm{H}$ at the $\mathrm{C} 5$ and the $\mathrm{C} 2$ position of glucose represents the fractional gluconeogenesis (114). To measure ${ }^{2} \mathrm{H}$ at the $\mathrm{C} 5$ position of glucose, glucose has to be converted to hexamethylenetetramine gas and is subsequently analyzed on a gas chromatograph-mass spectrometer. The enrichment of ${ }^{2} \mathrm{H}$ at $\mathrm{C} 2$ of glucose is determined via measurement of plasma ${ }^{2} \mathrm{H}_{2} \mathrm{O}$ enrichment with isotope ratio mass spectroscopy since in steady state the enrichment of ${ }^{2} \mathrm{H}$ at $\mathrm{C} 2$ of glucose equals the plasma ${ }^{2} \mathrm{H}_{2} \mathrm{O}$ enrichment $(114,115)$. To measure endogenous glucose production a continuous infusion of $\left[6,6-{ }^{2} \mathrm{H}_{2}\right]$ glucose with a primer can be given in combination with the ${ }^{2} \mathrm{H}_{2} \mathrm{O}$; the absolute rate of gluconeogenesis can be calculated by multiplying fractional gluconeogenesis with endogenous glucose production (116). Measurement of gluconeogenesis and energy expenditure after a high protein diet will give more information regarding the question whether gluconeogenesis contributes to a higher energy expenditure at a high protein diet. 


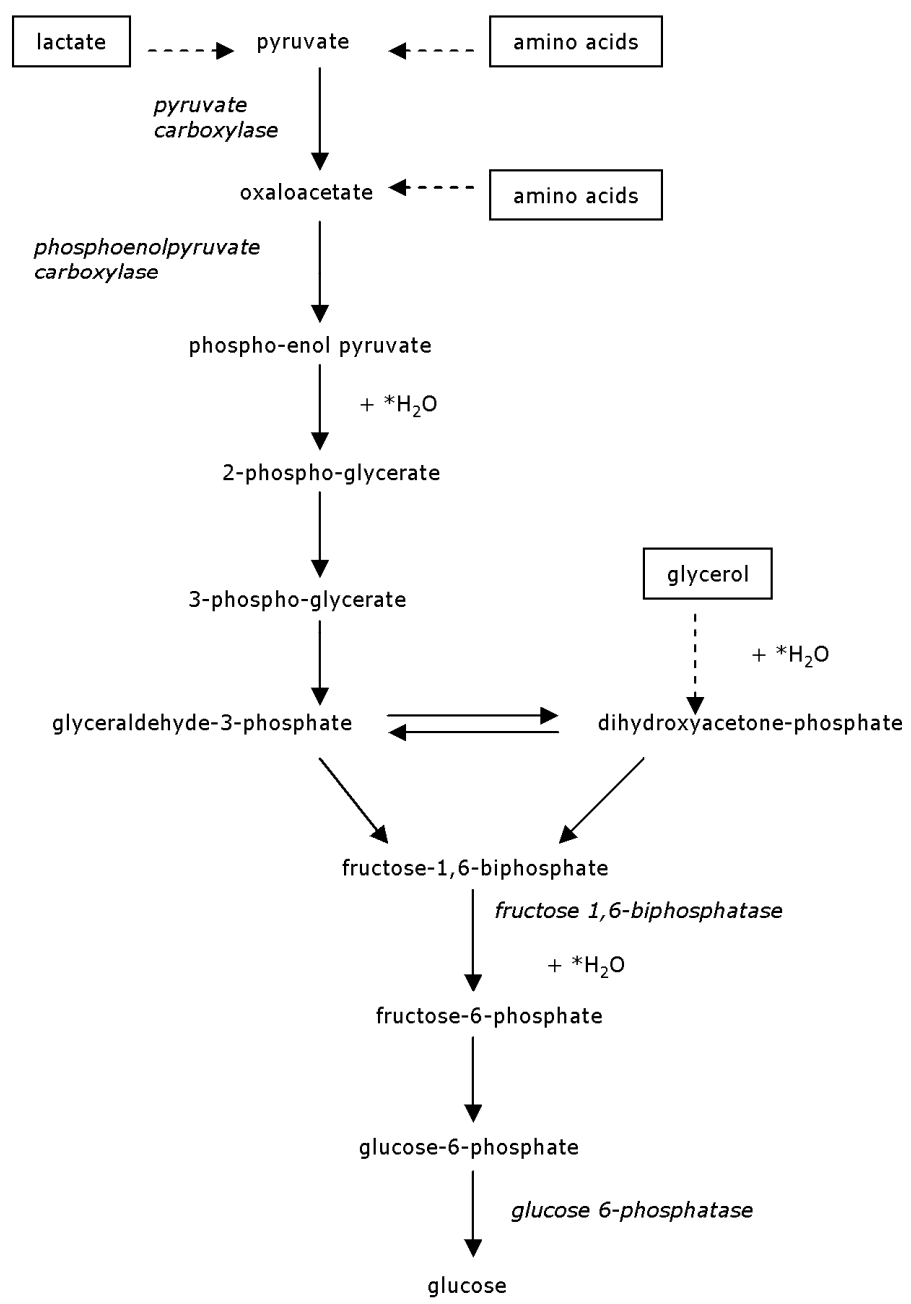

Figure 1 Pathway of the production of glucose through gluconeogenesis. Pyruvate carboxylase, phospho-enolpyruvate carboxylase, fructose 1,6-biphosphatase, and glucose 6-phosphatase are the most important enzymes involved. ${ }^{*} \mathrm{H}_{2} \mathrm{O}$ represents a site where $\mathrm{H}_{2} \mathrm{O}$ is incorporated into a precursor of glucose 


\section{OUTLINE OF THE THESIS}

Taken together, protein intake and protein metabolism seem to affect control of food intake and energy expenditure, as represented in figure 2. Splanchnic extraction of amino acids and the continuous breakdown and (re)synthesis of proteins determine the level and type of amino acids in the circulation. Concentrations of peptides or amino acids may affect central control of appetite directly or indirectly, for instance via (an)orexigenic hormones such as GLP-1, PYY, or ghrelin. Since the body has no storage capacity to cope with high protein intake it has to metabolize excess proteins immediately. Processes involved, such as protein synthesis, ureagenesis, and gluconeogenesis, are energetically costly and may increase total energy expenditure.

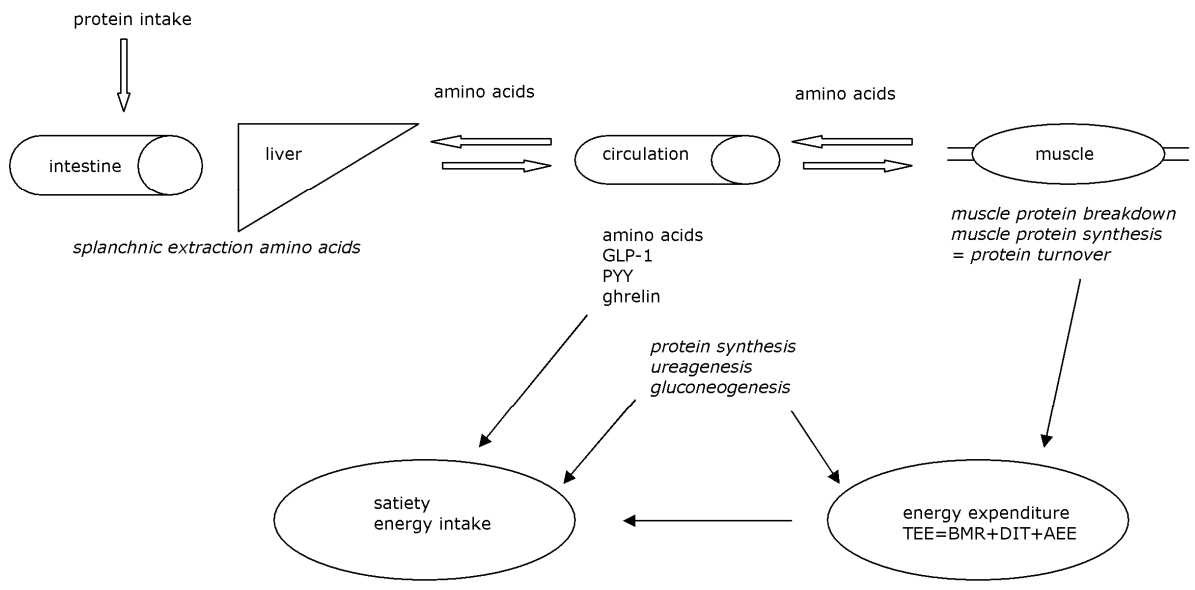

Figure 2 Effects of protein intake and protein metabolism on the control of energy intake and energy expenditure

The studies that are described in this thesis investigate the effects of dietary proteins on energy intake as well as on energy expenditure. Firstly, effects of high protein meals and high protein diets on appetite and subsequent energy intake and possible mechanisms contributing to differences are reviewed (chapter 2). The following chapters address the questions 1 ) whether a higher satiety after high protein intake holds for specific types of protein, 2) whether different types of protein have different satiating efficacies, and 3) whether differences in proteininduced satiety may be attributed to differences in (an)orexigenic hormones and/or amino acid responses. Effects of a high or normal amount of casein, soy, or whey with or without GMP on appetite were studied in a realistic meal setting, using iso-energetic breakfasts that did not differ in taste or hedonic value. Plasma amino acid and hormone concentrations were measured to study possible mechanisms contributing to differences in satiating efficacies. Based on appetite ratings and blood parameters the sensitive moment in time was determined to offer an ad libitum lunch to assess the effect of protein concentration or type on subsequent energy intake 
(chapter 3, 4, 5, and 6). In addition, seven different types of protein (casein, soy, whey with or without GMP, alpha-lactalbumin, gelatin, and gelatin with added TRP) were compared with respect to their effects on appetite ratings and subsequent energy intake at lunch (chapter 7). Although it seems that, based on weight-loss studies, high protein diets with low carbohydrate content may be more effective in reducing body weight than high protein diets with a normal proportion of carbohydrates, effects of these two diets on the metabolic targets appetite, energy expenditure, and fat oxidation have not been compared under controlled conditions. The question whether the presence or absence of carbohydrates in a relatively high protein diet is of significance for affecting appetite, energy expenditure, and fat oxidation is addressed in chapter 8. One of the mechanisms that is hypothesized to contribute to increase in energy expenditure after a high protein diet is gluconeogenesis. Energy expenditure and gluconeogenesis are measured in healthy, normal weight subjects who consumed a high protein, carbohydrate-free diet. It is studied whether this diet increases gluconeogenesis and whether an increase in energy expenditure can be attributed to an increase in gluconeogenesis (chapter 9). Finally, in chapter 10 the results of the above described studies are summarized and discussed in a general discussion.

\section{REFERENCES}

1. Obesity: preventing and managing the global epidemic. Report of a WHO consultation. World Health Organ Tech Rep Ser 2000;894:i-xii, 1-253.

2. Freedman MR, King J, Kennedy E. Popular diets: a scientific review. Obes Res 2001;9 Suppl 1:1S-40S.

3. Clifton PM. Dietary treatment for obesity. Nat Clin Pract Gastroenterol Hepatol 2008;5:672-81.

4.

Brand-Miller JC, Holt SH, Pawlak DB, McMillan J. Glycemic index and obesity. Am J Clin Nutr 2002;76:281S-5S.

Kushner RF, Doerfler B. Low-carbohydrate, high-protein diets revisited. Curr Opin Gastroenterol 2008;24:198203.

6. Eisenstein J, Roberts SB, Dallal G, Saltzman E. High-protein weight-loss diets: are they safe and do they work? A review of the experimental and epidemiologic data. Nutr Rev 2002;60:189-200.

7. Halton TL, Hu FB. The effects of high protein diets on thermogenesis, satiety and weight loss: a critical review. $J$ Am Coll Nutr 2004;23:373-85.

8. Westerterp-Plantenga MS, Luscombe-Marsh N, Lejeune MP, et al. Dietary protein, metabolism, and bodyweight regulation: dose-response effects. Int J Obes (Lond) 2006;30 Suppl 3:S16-23.

9. Brehm BJ, D'Alessio DA. Benefits of high-protein weight loss diets: enough evidence for practice? Curr Opin Endocrinol Diabetes Obes 2008;15:416-21.

10. Stock MJ. Gluttony and thermogenesis revisited. Int J Obes Relat Metab Disord 1999;23:1105-17.

11. (FNB) FaNB. Dietary Reference Intakes for Energy, Carbohydrate, Fiber, Fat, Fatty Acids, Cholesterol, Protein, and Amino Acids (Macronutrients) A Report of the Panel on Macronutrients, Subcommittees on Upper Reference Levels of Nutrients and Interpretation and Uses of Dietary Reference Intakes, and the Standing Committee on the Scientific Evaluation of Dietary Reference Intakes. Washington, D.C: INSTITUTE OF MEDICINE OF THE NATIONAL ACADEMIES THE NATIONAL ACADEMIES PRESS, 2005. Protein and amino acid requirements in human nutrition. World Health Organ Tech Rep Ser 2007:1-265, back cover.

13. Hulshof K, Ocke M, van Rossum C, et al. Results of the Food Consumption Survey 2003 (In Dutch: Resultaten van de Voedselconsumptiepeiling 2003). Bilthoven/Zeist: RIVM/TNO, 2004.

Westerterp-Plantenga MS. Protein intake and energy balance. Regul Pept 2008;149:67-9.

Westerterp-Plantenga MS. How are normal, high- or low-protein diets defined? Br J Nutr 2007;97:217-8.

Stryer L. Biochemistry. New York: W.H. Freeman and Company, 1999.

Matthews DE. Proteins and amino acids. In: Shils ME, Shike M, eds. Modern nutrition in health and disease. 10 ed. Philadelphia: Lippincot Williams \& Wilkins, 2006:23-61.

18. Millward DJ, Layman DK, Tome D, Schaafsma G. Protein quality assessment: impact of expanding understanding of protein and amino acid needs for optimal health. Am J Clin Nutr 2008;87:1576S-1581S.

19. Munro HN. Second Boyd Orr Memorial Lecture. Regulation of body protein metabolism in relation to diet. Proc Nutr Soc 1976;35:297-308. 
20.

21.

Waterlow JC, Garlick PJ, Millward DJ. Protein turnover in the mammalian tissues and in the whole body Amsterdam: North Holland Publishing, 1978.

Deutz NE, Wagenmakers AJ, Soeters PB. Discrepancy between muscle and whole body protein turnover. Curr Opin Clin Nutr Metab Care 1999;2:29-32.

Liu Z, Barrett EJ. Human protein metabolism: its measurement and regulation. Am J Physiol Endocrinol Metab 2002;283:E1105-12.

De Feo P. Hormonal regulation of human protein metabolism. Eur J Endocrinol 1996;135:7-18.

Rennie MJ, Tipton KD. Protein and amino acid metabolism during and after exercise and the effects of nutrition. Annu Rev Nutr 2000;20:457-83.

Young VR, Scrimshaw NS, Bier DM. Whole body protein and amino acid metabolism: relation to protein quality evaluation in human nutrition. J Agric Food Chem 1981;29:440-7.

Pannemans DL, Halliday D, Westerterp KR, Kester AD. Effect of variable protein intake on whole-body protein turnover in young men and women. Am J Clin Nutr 1995;61:69-74.

Garlick PJ, McNurlan MA, Ballmer PE. Influence of dietary protein intake on whole-body protein turnover in humans. Diabetes Care 1991;14:1189-98.

Melville S, McNurlan MA, McHardy KC, et al. The role of degradation in the acute control of protein balance in adult man: failure of feeding to stimulate protein synthesis as assessed by L-[1-13C]leucin infusion. Metabolism 1989;38:248-55.

Hoffer L, Yang RD, Matthews DE, Bistrian BR, Bier DM, Young VR. Effects of meal consumption on whole body leucine and alanine kinetics in young adult men. Br J Nutr 1985;53:31-8.

Tessari P, Kiwanuka E, Zanetti M, Barazzoni R. Postprandial body protein synthesis and amino acid catabolism measured with leucine and phenylalanine-tyrosine tracers. Am J Physiol Endocrinol Metab 2003;284:E1037-42.

Biolo G, Tipton KD, Klein S, Wolfe RR. An abundant supply of amino acids enhances the metabolic effect of exercise on muscle protein. Am J Physiol 1997;273:E122-9.

Tipton KD, Ferrando AA, Phillips SM, Doyle D, Jr., Wolfe RR. Postexercise net protein synthesis in human muscle from orally administered amino acids. Am J Physiol 1999;276:E628-34.

Pacy PJ, Price GM, Halliday D, Quevedo MR, Millward DJ. Nitrogen homeostasis in man: the diurnal responses of protein synthesis and degradation and amino acid oxidation to diets with increasing protein intakes. Clin Sci (Lond) 1994;86:103-16.

Pannemans DL, Wagenmakers AJ, Westerterp KR, Schaafsma G, Halliday D. Effect of protein source and quantity on protein metabolism in elderly women. Am J Clin Nutr 1998;68:1228-35.

Latner JD, Schwartz M. The effects of a high-carbohydrate, high-protein or balanced lunch upon later food intake and hunger ratings. Appetite 1999;33:119-28.

Westerterp-Plantenga MS, Rolland V, Wilson SA, Westerterp KR. Satiety related to $24 \mathrm{~h}$ diet-induced thermogenesis during high protein/carbohydrate vs high fat diets measured in a respiration chamber. Eur J Clin Nutr 1999;53:495-502.

Lejeune MP, Kovacs EM, Westerterp-Plantenga MS. Additional protein intake limits weight regain after weight loss in humans. Br J Nutr 2005;93:281-9.

Lejeune MP, Westerterp KR, Adam TC, Luscombe-Marsh ND, Westerterp-Plantenga MS. Ghrelin and glucagonlike peptide 1 concentrations, 24-h satiety, and energy and substrate metabolism during a high-protein diet and measured in a respiration chamber. Am J Clin Nutr 2006;83:89-94.

Westerterp-Plantenga MS, Lejeune MP, Nijs I, van Ooijen M, Kovacs EM. High protein intake sustains weight maintenance after body weight loss in humans. Int J Obes Relat Metab Disord 2004;28:57-64.

Blundell JE, Halford JC. Regulation of nutrient supply: the brain and appetite control. Proc Nutr Soc 1994;53:407-18.

Kyriazakis I, Emmans GC. Selection of a diet by growing pigs given choices between foods differing in contents of protein and rapeseed meal. Appetite 1992;19:121-32.

Kyriazakis I, Emmans GC, Whittemore CT. The ability of pigs to control their protein intake when fed in three different ways. Physiol Behav 1991;50:1197-203.

Walls EK, Koopmans HS. Differential effects of intravenous glucose, amino acids, and lipid on daily food intake in rats. Am J Physiol 1992;262:R225-34.

Gietzen DW, Hao S, Anthony TG. Mechanisms of food intake repression in indispensable amino acid deficiency. Annu Rev Nutr 2007;27:63-78.

Flint A, Raben A, Blundell JE, Astrup A. Reproducibility, power and validity of visual analogue scales in assessment of appetite sensations in single test meal studies. Int J Obes Relat Metab Disord 2000;24:38-48.

Rogers PJ, Blundell JE. Separating the actions of sweetness and calories: effects of saccharin and carbohydrates on hunger and food intake in human subjects. Physiol Behav 1989;45:1093-9.

Stubbs RJ, Hughes DA, Johnstone AM, et al. The use of visual analogue scales to assess motivation to eat in human subjects: a review of their reliability and validity with an evaluation of new hand-held computerized systems for temporal tracking of appetite ratings. Br J Nutr 2000;84:405-15.

48. Lenard NR, Berthoud HR. Central and peripheral regulation of food intake and physical activity: pathways and genes. Obesity (Silver Spring) 2008;16 Suppl 3:S11-22. 
49.

50.

51.

52.

53.

54.

55.

56.

57.

58.

59.

60.

61.

62.

63.

64.

65.

66.

67.

68.

69.

70.

71.

72.

73.

74.

75.

76.

77.

78.

79.

80.

81.

82.

Schwartz MW, Woods SC, Porte D, Jr., Seeley RJ, Baskin DG. Central nervous system control of food intake. Nature 2000;404:661-71.

Wynne K, Stanley S, McGowan B, Bloom S. Appetite control. J Endocrinol 2005;184:291-318.

Woods SC, D'Alessio DA. Central control of body weight and appetite. J Clin Endocrinol Metab 2008;93:S37-50.

Druce MR, Small CJ, Bloom SR. Minireview: Gut peptides regulating satiety. Endocrinology 2004;145:2660-5.

Benoit SC, Clegg DJ, Seeley RJ, Woods SC. Insulin and leptin as adiposity signals. Recent Prog Horm Res 2004;59:267-85

Beglinger C, Degen L. Gastrointestinal satiety signals in humans--physiologic roles for GLP-1 and PYY? Physiol Behav 2006;89:460-4

Wynne K, Bloom SR. The role of oxyntomodulin and peptide tyrosine-tyrosine (PYY) in appetite control. Nat Clin Pract Endocrinol Metab 2006;2:612-20

Moran TH, Kinzig KP. Gastrointestinal satiety signals II. Cholecystokinin. Am J Physiol Gastrointest Liver Physio 2004;286:G183-8.

VanderWeele DA. Insulin is a prandial satiety hormone. Physiol Behav 1994;56:619-22.

Cummings DE. Ghrelin and the short- and long-term regulation of appetite and body weight. Physiol Behav 2006;89:71-84.

Cummings DE, Overduin J. Gastrointestinal regulation of food intake. J Clin Invest 2007;117:13-23.

Tome D. Protein, amino acids and the control of food intake. Br J Nutr 2004;92 Suppl 1:S27-30.

Potier M, Darcel N, Tome D. Protein, amino acids and the control of food intake. Curr Opin Clin Nutr Metab Care 2009;12:54-8.

Crovetti R, Porrini M, Santangelo A, Testolin G. The influence of thermic effect of food on satiety. Eur J Clin Nutr 1998;52:482-8.

Westerterp KR, Wilson SA, Rolland V. Diet induced thermogenesis measured over $24 \mathrm{~h}$ in a respiration chamber: effect of diet composition. Int J Obes Relat Metab Disord 1999;23:287-92.

Westerterp-Plantenga MS, Westerterp KR, Rubbens M, Verwegen CR, Richelet JP, Gardette B. Appetite at "high altitude" [Operation Everest III (Comex-'97)]: a simulated ascent of Mount Everest. J Appl Physiol 1999;87:3919.

Azzout-Marniche D, Gaudichon C, Blouet C, et al. Liver glyconeogenesis: a pathway to cope with postprandial amino acid excess in high-protein fed rats? Am J Physiol Regul Integr Comp Physiol 2007;292:R1400-7.

Morens C, Bos C, Pueyo ME, et al. Increasing habitual protein intake accentuates differences in postprandial dietary nitrogen utilization between protein sources in humans. J Nutr 2003;133:2733-40.

Mellinkoff SM, Frankland M, Boyle D, Greipel M. Relationship between serum amino acid concentration and fluctuations in appetite. J Appl Physiol 1956;8:535-8.

Faipoux R, Tome D, Gougis S, Darcel N, Fromentin G. Proteins activate satiety-related neuronal pathways in the brainstem and hypothalamus of rats. J Nutr 2008;138:1172-8.

Bowen J, Noakes M, Clifton PM. Appetite regulatory hormone responses to various dietary proteins differ by body mass index status despite similar reductions in ad libitum energy intake. J Clin Endocrinol Metab 2006;91:2913-9.

Bowen J, Noakes M, Trenerry C, Clifton PM. Energy intake, ghrelin, and cholecystokinin after different carbohydrate and protein preloads in overweight men. J Clin Endocrinol Metab 2006;91:1477-83.

Hall WL, Millward DJ, Long SJ, Morgan LM. Casein and whey exert different effects on plasma amino acid profiles, gastrointestinal hormone secretion and appetite. Br J Nutr 2003;89:239-48.

Lang V, Bellisle F, Alamowitch C, et al. Varying the protein source in mixed meal modifies glucose, insulin and glucagon kinetics in healthy men, has weak effects on subjective satiety and fails to affect food intake. Eur J Clin Nutr 1999;53:959-65.

Lang V, Bellisle F, Oppert JM, et al. Satiating effect of proteins in healthy subjects: a comparison of egg albumin, casein, gelatin, soy protein, pea protein, and wheat gluten. Am J Clin Nutr 1998;67:1197-204.

Anderson GH, Tecimer SN, Shah D, Zafar TA. Protein source, quantity, and time of consumption determine the effect of proteins on short-term food intake in young men. J Nutr 2004;134:3011-5.

Batterham RL, Heffron H, Kapoor S, et al. Critical role for peptide YY in protein-mediated satiation and bodyweight regulation. Cell Metab 2006;4:223-33.

Boirie Y, Dangin M, Gachon P, Vasson MP, Maubois JL, Beaufrere B. Slow and fast dietary proteins differently modulate postprandial protein accretion. Proc Natl Acad Sci U S A 1997;94:14930-5.

Dangin M, Boirie Y, Garcia-Rodenas C, et al. The digestion rate of protein is an independent regulating factor of postprandial protein retention. Am J Physiol Endocrinol Metab 2001;280:E340-8.

Dangin M, Boirie Y, Guillet C, Beaufrere B. Influence of the protein digestion rate on protein turnover in young and elderly subjects. J Nutr 2002;132:3228S-33S.

Marshall K. Therapeutic applications of whey protein. Altern Med Rev 2004;9:136-56.

Pedersen NL, Nagain-Domaine C, Mahe S, Chariot J, Roze C, Tome D. Caseinomacropeptide specifically stimulates exocrine pancreatic secretion in the anesthetized rat. Peptides 2000;21:1527-35.

Burton-Freeman BM. Glycomacropeptide (GMP) is not critical to whey-induced satiety, but may have a unique role in energy intake regulation through cholecystokinin (CCK). Physiol Behav 2008;93:379-87.

Velasquez MT, Bhathena SJ. Role of dietary soy protein in obesity. Int J Med Sci 2007;4:72-82. 
83.

84.

85.

86.

87.

88.

89.

90.

91.

92.

93.

94.

95.

96.

97.

98.

99.

100

101

102

103.

104.

105.

106.

107

108.

109.

110

111.

112.

113.

114.

115.

116

Wurtman RJ, Wurtman JJ. Do carbohydrates affect food intake via neurotransmitter activity? Appetite 1988;11 Suppl 1:42-7.

Halford JC, Harrold JA, Boyland EJ, Lawton CL, Blundell JE. Serotonergic drugs : effects on appetite expression and use for the treatment of obesity. Drugs 2007;67:27-55.

Toornvliet AC, Pijl H, Hopman E, Elte-de Wever BM, Meinders AE. Serotoninergic drug-induced weight loss in carbohydrate craving obese patients. Int J Obes Relat Metab Disord 1996;20:917-20.

Beulens JW, Bindels JG, de Graaf C, Alles MS, Wouters-Wesseling W. Alpha-lactalbumin combined with a regular diet increases plasma Trp-LNAA ratio. Physiol Behav 2004;81:585-93.

Sorensen LB, Moller P, Flint A, Martens M, Raben A. Effect of sensory perception of foods on appetite and food intake: a review of studies on humans. Int J Obes Relat Metab Disord 2003;27:1152-66.

Mattes RD, Rothacker D. Beverage viscosity is inversely related to postprandial hunger in humans. Physiol Behav 2001;74:551-7.

Devitt AA, Mattes RD. Effects of food unit size and energy density on intake in humans. Appetite 2004;42:21320.

Westerterp KR. Energy expenditure. In: Westerterp-Plantenga MS, Fredrix EWHM, Steffens AB, eds. Food intake and energy expenditure: CRC Press, 1994:235-257.

Ravussin E, Bogardus C. Relationship of genetics, age, and physical fitness to daily energy expenditure and fue utilization. Am J Clin Nutr 1989;49:968-75.

Harris JA, Benedict FG. A biometric study of basal metabolism in man. Proc Natl Acad Sci 1918;4:370-373.

Waterlow JC. Whole-body protein turnover in humans--past, present, and future. Annu Rev Nutr 1995;15:5792.

Wolfe RR. The underappreciated role of muscle in health and disease. Am J Clin Nutr 2006;84:475-82.

Westerterp KR. Diet induced thermogenesis. Nutr Metab (Lond) 2004;1:5.

Westerterp KR. Alterations in energy balance with exercise. Am J Clin Nutr 1998;68:970S-974S.

Raben A, Agerholm-Larsen L, Flint A, Holst JJ, Astrup A. Meals with similar energy densities but rich in protein, fat, carbohydrate, or alcohol have different effects on energy expenditure and substrate metabolism but not on appetite and energy intake. Am J Clin Nutr 2003;77:91-100.

Johnston CS, Day CS, Swan PD. Postprandial thermogenesis is increased $100 \%$ on a high-protein, low-fat diet versus a high-carbohydrate, low-fat diet in healthy, young women. J Am Coll Nutr 2002;21:55-61.

Mikkelsen PB, Toubro S, Astrup A. Effect of fat-reduced diets on 24-h energy expenditure: comparisons between animal protein, vegetable protein, and carbohydrate. Am J Clin Nutr 2000;72:1135-41.

Robinson SM, Jaccard C, Persaud C, Jackson AA, Jequier E, Schutz Y. Protein turnover and thermogenesis in response to high-protein and high-carbohydrate feeding in men. Am J Clin Nutr 1990;52:72-80.

van Milgen J. Modeling biochemical aspects of energy metabolism in mammals. J Nutr 2002;132:3195-202.

Giordano M, Castellino P. Correlation between amino acid induced changes in energy expenditure and protein metabolism in humans. Nutrition 1997;13:309-12.

Tremblay $\mathrm{F}$, Lavigne $\mathrm{C}$, Jacques $\mathrm{H}$, Marette A. Role of dietary proteins and amino acids in the pathogenesis of insulin resistance. Annu Rev Nutr 2007;27:293-310.

Exton JH. Gluconeogenesis. Metabolism 1972;21:945-90.

Gerich JE. Control of glycaemia. Baillieres Clin Endocrinol Metab 1993;7:551-86.

Nuttall FQ, Ngo A, Gannon MC. Regulation of hepatic glucose production and the role of gluconeogenesis in humans: is the rate of gluconeogenesis constant? Diabetes Metab Res Rev 2008;24:438-58.

Wahren J, Ekberg K. Splanchnic regulation of glucose production. Annu Rev Nutr 2007;27:329-45.

Hue L. Gluconeogenesis and its regulation. Diabetes Metab Rev 1987;3:111-26.

Exton JH, Mallette LE, Jefferson LS, et al. The hormonal control of hepatic gluconeogenesis. Recent Prog Horm Res 1970;26:411-61.

Azzout B, Chanez M, Bois-Joyeux B, Peret J. Gluconeogenesis from dihydroxyacetone in rat hepatocytes during the shift from a low protein, high carbohydrate to a high protein, carbohydrate-free diet. J Nutr 1984;114:216778.

Kaloyianni M, Freedland RA. Contribution of several amino
isolated from rats fed various diets. J Nutr 1990;120:116-22 Feinman RD, Fine EJ. Thermodynamics and metabolic advantage of weight loss diets. Metab Syndr Relat Disord 2003;1:209-19.

Hall KD. Computational model of in vivo human energy metabolism during semistarvation and refeeding. Am J Physiol Endocrinol Metab 2006;291:E23-37.

Landau BR, Wahren J, Chandramouli V, Schumann WC, Ekberg K, Kalhan SC. Contributions of gluconeogenesis to glucose production in the fasted state. J Clin Invest 1996;98:378-85.

Ackermans MT, Pereira Arias AM, Bisschop PH, Endert E, Sauerwein HP, Romijn JA. The quantification of gluconeogenesis in healthy men by $(2) \mathrm{H} 2 \mathrm{O}$ and [2-(13)C]glycerol yields different results: rates of gluconeogenesis in healthy men measured with (2) $\mathrm{H} 2 \mathrm{O}$ are higher than those measured with [2-(13)C]glycerol. J Clin Endocrinol Metab 2001;86:2220-6.

Chandramouli V, Ekberg K, Schumann WC, Kalhan SC, Wahren J, Landau BR. Quantifying gluconeogenesis during fasting. Am J Physiol 1997;273:E1209-15. 

Chapter 2

\section{Protein-induced satiety: Effects and mechanisms of different proteins}

Veldhorst MAB, Smeets AJPG, Soenen S, Hochstenbach-Waelen A, Hursel R, Diepvens K, Lejeune MPGM, Luscombe-Marsh ND, Westerterp-Plantenga MS

Physiol Behav 2008; 94: 300-307 


\section{ABSTRACT}

Relatively high protein diets, i.e. diets that maintain the absolute number of grams of protein ingested as compared to before dieting, are a popular strategy for weight loss and weight maintenance. Research into multiple mechanisms regulating body weight has focused on the effects of different quantities and types of dietary protein. Satiety and energy expenditure are important in protein-enhanced weight loss and weight maintenance. Protein-induced satiety has been shown acutely, with single meals, with contents of $25 \%$ to $81 \%$ of energy from protein in general or from specific proteins, while subsequent energy intake reduction was significant.

Protein-induced satiety has been shown with high-protein ad libitum diets, lasting from 1 to 6 days, up to 6 months. Also significantly greater weight loss has been observed in comparison with control.

Mechanisms explaining protein-induced satiety are nutrient specific, and consist mainly of synchronization with elevated amino acid concentrations.

Different proteins cause different nutrient related responses of (an)orexigenic hormones. Protein-induced satiety coincides with a relatively high GLP-1 release, stimulated by the carbohydrate content of the diet, PYY release, while ghrelin does not seem to be especially affected, and little information is available on CCK. Protein-induced satiety is related to proteininduced energy expenditure. Finally, protein-induced satiety appears to be of vital importance for weight loss and weight maintenance.

With respect to possible adverse events, chronic ingestion of large amounts of sulphurcontaining amino acids may have an indirect effect on blood pressure by induction of renal subtle structural damage, ultimately leading to loss of nephron mass, and a secondary increase in blood pressure. The established synergy between obesity and low nephron number on induction of high blood pressure and further decline of renal function identifies subjects with obesity, metabolic syndrome and diabetes mellitus 2 as particularly susceptible groups.

KEYWORDS: $\quad$ protein, satiety, meals, diet 


\section{INTRODUCTION}

Obesity is a major health problem with serious comorbidities such as diabetes mellitus type 2 , cardiovascular disease, and numerous types of cancer $(1,2)$. The solution for the problem of overweight and obesity in humans is body-weight maintenance after body weight loss. This seems simple but the required conditions are difficult to achieve for many individuals. Conditions for successful weight maintenance are (i) sustained satiety despite a negative energy balance, (ii) sustained basal energy expenditure despite body weight loss due to (iii) sparing of fat free mass, since fat free mass is the main determinant of basal energy expenditure.

In the context of research on prevention and treatment of overweight and obesity, relatively high protein diets have come into focus as having the potential to act on the different metabolic targets regulating body weight (3) and thereby providing the required conditions for successful weight maintenance after weight loss.

Until now, most of the research on this phenomenon has been executed with different quantities of protein.

The World Health Organization (WHO) recommends that dietary protein should account for $\sim 10-15 \%$ of energy intake when in energy balance and weight stable (4). Average daily protein intakes in various countries indicate that these recommendations are reflective of what is being consumed worldwide (5-9). Given the range of the normal protein intake, meals with on average $20 \%$ to $30 \%$ of energy from protein are representative for high protein diets already, when consumed in energy balance (3). Accordingly, we consider on average $~ 10-15 \%$ of energy intake from protein, when in energy balance and weight stable as a normal protein intake, and $>15 \%$ of energy intake from protein, when in energy balance and weight stable, as a high protein intake. When subjects are not in energy balance, the relative percentages of protein intake shift, and preferably also absolute amounts of protein intake should be considered (10).

Research with different types of protein is scarce, yet increasing.

In this review we will focus on the target satiety, and give an overview of the evidence with respect to the quantity and types of protein in meals and diets showing protein-induced satiety. Mechanisms involved in onset and maintenance of protein-induced satiety will be discussed.

\section{PROTEIN-INDUCED SATIETY BY ACUTE HIGH PROTEIN MEALS AND MEDIUM-TERM HIGH PROTEIN DIETS}

A hierarchy has been observed for the satiating efficacies of the macronutrients protein, carbohydrate and fat, with protein being the most satiating and fat the least. At the same time a priority has been shown with respect to metabolising these macronutrients (11-13). Usually mixed proteins are used, from meat, fish, plants or dairy products. A dose dependent satiating effect of protein has been shown, with quite a range of concentrations of protein offered acutely, in a single meal, to subjects who are in energy balance and weight stable (14-16). In addition, persistent protein-induced satiety has been shown when a high protein diet was given for $24 \mathrm{~h}$ up to several days $(11,17-19)$. This section discusses acute, high protein meal-induced satiety, and medium term, high protein diet-induced satiety. Mechanisms contributing to protein-induced satiety are considered. 


\section{Acute high-protein meal induced satiety}

Postprandial satiety was assessed thereby comparing effects of meals with extremely high protein versus normal protein content. Stubbs (20) reported a larger satiety after a high protein meal with $60 \%$ protein as compared to a meal with $19 \%$ protein $(p<0.001)$; Crovetti $(21)$ observed a larger satiety after a high protein meal with $68 \%$ of energy from protein compared with a meal with $10 \%$ of energy from protein $(p<0.01)$. Both of these studies used $100 \mathrm{~mm}$ anchored visual analogue scales (VAS) to assess satiety.

Energy intake was measured by Barkeling et al. (14) and Johnson et al. (22), in addition to such VAS assessments. After an ad libitum homogenous lunch meal with $43 \%$ as compared with $10 \%$ of energy from protein, Barkeling observed a significantly smaller energy intake $(p<0.05)(14)$. Johnson (22) also showed a larger satiety $(p<0.05)$ and smaller energy intake $(p<0.01)$ after a meal with $81 \%$ compared with $14 \%$ of energy from protein.

Other researchers have compared effects of a high protein meal in a range representative for the average protein intake during a high protein meal i.e. 20-30\% of energy. Hill and Blundell (15) compared meals with $31 \%$ and $15 \%$ of energy as protein respectively and reported a larger satiety induced by the higher protein meal $(p<0.05)$.

Given the range of the 'normal' protein intake, meals with on average $20 \%$ to $30 \%$ of energy from protein are representative for high protein meals, when consumed in energy balance (3). This range is representative of what can be reached on average on a daily basis; yet fluctuations in macronutrient compositions may show differences in protein intake between meals. In a study of Smeets et al. (16) acute effects of a high-protein lunch on energy expenditure (diet induced energy expenditure, DEE), substrate oxidation, satiety related hormones (GLP-1, ghrelin, and PYY) and satiety were tested in thirty healthy subjects with a body mass index (BMI; in $\mathrm{kg} / \mathrm{m}^{2}$ ) of $20-30$ and aged $18-60$ years. The macronutrient composition of the lunch was either $10 / 60 / 30 \%$ of energy from protein/carbohydrate/fat (adequate protein, AP) or $25 / 45 / 30 \%$ of energy from protein/carbohydrate/fat (high protein, HP). Both lunches provided $35 \%$ of each subject's individual daily energy requirements and consisted of pasta, sausages, and tomato sauce. AP lunch and HP lunch were equal in energy content ( $\mathrm{kJ})$, weight $(\mathrm{g})$ and energy density $(\mathrm{kJ} / \mathrm{g})$. After the high protein lunch satiety was significantly higher than after the normal protein lunch $(p<0.02)(16)$.

Taken together, protein-induced satiety has been shown acutely, with single meals, with contents of $25 \%$ to $81 \%$ of energy from protein in general or from specific proteins $(14-16,20$, 22). Also subsequent energy intake reduction has been shown $(14,22)$.

\section{High protein diet-induced satiety}

When high protein menus are offered at each meal, lasting for one to several days, one gets into the condition of a high protein diet. The difference between the acute situation of a high protein meal and a continuously high protein diet is that with the latter one's respiratory quotient (RQ) matches one's Food Quotient ( $F Q$; $F Q$ represents the RQ when all nutrients are oxidized). Moreover, all possible metabolic reactions have then been established also $(11,19,23)$.

In several high protein diet studies lasting for $24 \mathrm{~h}$ up to 5 days a continuously higher satiety has been shown throughout the day after the high compared with the normal protein diet.

For example, in a controlled environment of a respiration chamber, satiety and metabolic rate were assessed over $24 \mathrm{~h}$, comparing high versus normal protein diets (protein 
/carbohydrate/fat: $30 / 60 / 10 \%$ of energy vs. $10 / 30 / 60 \%$ of energy), while subjects were fed in energy balance. Throughout the day, satiety and fullness were higher on the high protein diet, while hunger, appetite, desire to eat, and estimated quantity that could be eaten were lower than on the normal protein, high carbohydrate, low fat diet (11). Subsequently, in a similar respiration chamber experiment, several mechanisms of protein-induced satiety were assessed simultaneously (19). Lean women were fed in energy balance with an adequate or high protein diet which contained $10 / 60 / 30 \%$ of energy or $30 / 40 / 30 \%$ of energy from protein/carbohydrate/fat, implying $\sim 60 \mathrm{~g}$ or $\sim 180 \mathrm{~g}$ of protein respectively, for 4 days. Results showed that the high protein diet increased 24-hour satiety over the 4 days and decreased hunger compared with the adequate protein diet, while there was no difference in energy intake between the two regimens, since the subjects were fed in energy balance. This supports the hypothesis that protein increases satiety to a greater extent than carbohydrate or fat. The finding was also reflected in the relationship between 24-hour satiety and protein intake, which was seen only in the high protein diet. The protein intake during the high protein diet $(2.6 \pm 0.3$ $\mathrm{g} / \mathrm{kg}$ ) resulted in a positive protein balance, whereas the protein intake during the adequate protein diet $(1.0 \pm 0.1 \mathrm{~g} / \mathrm{kg})$ resulted in a protein balance that was not significantly different from zero. Thus, when protein intake exceeds protein requirement, satiety is positively related to absolute protein intake (19). Comparing the results from both experiments $(11,19)$ it appears that these are very similar. Therefore the effects of the high-protein diets do not seem to depend on the exchange with the type of other macronutrient. In experiment (11) protein was exchanged with fat and carbohydrate; in experiment (19) protein was exchanged with only carbohydrate, keeping fat constant. Since carbohydrate affects protein metabolism, it may be recommended for further experiments to exchange protein with fat, thereby applying measures to keep energy density constant.

Taken together, high protein diet studies lasting for $24 \mathrm{~h}$ up to 5 days show a continuously higher satiety throughout the day as compared with normal protein diet $(11,19,23)$.

\section{MECHANISMS REGARDING PROTEIN-INDUCED SATIETY}

Mechanisms that may contribute to protein-induced satiety are increases (i) in concentrations of 'satiety' hormones, (ii) in energy expenditure, (iii) in concentrations of metabolites, i.e. amino acids, and (iv) the process of gluconeogenesis.

\section{'Satiety' hormones}

It has been hypothesized that protein-induced satiety coincides with, is synchronized with, or is somehow related to a relatively high increase in concentrations of anorexigenic hormones (Glucagon-like peptide-1, Cholecystokinine, PYY) or a larger decrease in 'orexigenic' (ghrelin) hormones (16, 19, 23-27).

Although evidence for these larger changes in hormone concentrations after an extremely high protein preload has been shown by Hall et al. (25) it was not shown by Smeets et al. (16). In the latter study, no differences in ghrelin, GLP-1 and PYY responses between the high protein and adequate protein condition appeared, while the GLP-1 response appeared to be smaller following the high protein as compared to the adequate protein lunch; probably due to the high 
carbohydrate induced GLP-1 response during the adequate protein lunch. Here it was shown clearly that a GLP-1 response is primarily nutrient related, and only secondarily satiety related, since the high protein lunch evoked the higher satiety response but not a higher GLP-1 response, while the adequate protein but high carbohydrate lunch evoked the lower satiety response but higher GLP-1 response. Therefore the concentrations in 'anorexigenic' hormones may underscore the nutrient-induced satiety, but are not directly and mathematically related to satiety.

With respect to PYY responses, in a recent study Batterham et al. (27) observed significantly higher plasma PYY responses to a high protein meal in both lean and obese subjects.

Lejeune et al. (19) showed that protein-induced satiety during a high protein diet, which lasts for several days, was mediated through one of the anorexigenic hormones. Lean women were fed in energy balance with an adequate or high protein diet which contained $10 / 60 / 30 \%$ of energy or $30 / 40 / 30 \%$ of energy from protein/carbohydrate/fat, implying $\sim 60 \mathrm{~g}$ or $\sim 180 \mathrm{~g}$ of protein respectively for 4 days. Here, on the fourth day, GLP-1 concentrations throughout the day were measured. After dinner GLP-1 concentrations were significantly higher on a high protein diet than on an adequate protein diet (19). In a similar study in men, GLP-1 concentrations were elevated after high protein compared with normal protein meals at breakfast, lunch and dinner (22). From this we suggest that a high protein diet in the presence of carbohydrate, stimulates GLP-1 release, since carbohydrate stimulates protein metabolism (26).

Taken together, there is some evidence that a high protein meal in combination with carbohydrate stimulates GLP-1 release (19), yet this depends on the carbohydrate content (16, 19). Furthermore evidence has been given that PYY release is stimulated by a high protein meal (27). Ghrelin does not seem to be affected by a high protein meal or diet (19). Little information is available on CCK, so we cannot give a clear conclusion on its contribution to protein-induced satiety.

\section{Energy expenditure}

One of the mechanisms that has been suggested to explain protein-induced satiety is energy expenditure. A relationship between energy expenditure and protein-induced satiety mainly appeared in the condition of a high protein diet, and to a lesser extent after a single high protein meal.

Westerterp-Plantenga et al. observed that only on a high protein diet satiety was positively related to 24-hour diet-induced energy expenditure (DEE) (11). Lejeune et al. (19) reported that the higher satiety effect in women was related to total energy expenditure. Also Crovetti (21), offering a mixed high protein meal with 68 vs. $10 \%$ of energy from protein showed a relationship between satiety and energy expenditure.

The theoretical basis of this relationship may be that increased energy expenditure at rest implies increased oxygen consumption and an increase in body temperature that may lead to feeling deprived of oxygen and thus promote satiety (11). This idea is in line with higher satiety scores under limited oxygen availability conditions, as observed at high altitude and in patients with chronic obstructive pulmonary disease who also very quickly feel deprived of oxygen when they are eating (28).

Energy expenditure is different due to different protein sources. The metabolisable energy of protein, as defined in the Atwater factor, is $17 \mathrm{~kJ} / \mathrm{g}$. However, protein is particularly thermogenic 
and the net metabolisable energy is actually $13 \mathrm{~kJ} / \mathrm{g}$, making it lower than either carbohydrate or fat (29). The thermic effect of nutrients is related to the stimulation of energy-requiring processes during the postprandial period. It is based on the amount of ATP required for the initial steps of metabolism and storage. Reported values for separate nutrients are 0 to $3 \%$ for fat, 5 to $10 \%$ for carbohydrate, and 20 to $30 \%$ for protein (30). Thus, a high protein diet induces a greater thermic response in healthy subjects compared with a high fat diet (31).

The relatively strong thermic effect of protein may be mediated by the high ATP costs of postprandial protein synthesis $(32,33)$. Amino acid oxidation may play a major role, especially when amino acids are given in excess of protein deposition. Protein metabolism and, consequently, energy expenditure are dependent on the protein source. An important factor that determines postprandial protein metabolism is its digestion rate. Thus, ingestion of rapidly digested protein, such as whey, results in a stronger increase in postprandial protein synthesis and amino acid oxidation than slowly digested protein, such as casein (34-36).

Amino acid composition of the protein is a determinant of the metabolic efficacy of protein oxidation (hence, heat production) because large differences exist in the efficacy with which amino acids are oxidized. This is due to the large variety of carbon chains and co-factors that result from amino acid catabolism $(33,37)$. For instance, the number of amino groups that undergo conversion to urea in the urea cycle, at a cost of 4 ATP, ranges from 1 for an amino acid such as proline or alanine, to 3 for histidine $(33,37)$. Therefore, taking into account the stoichiometry of amino acid catabolism and urea synthesis, the calculated energy expenditure to produce ATP is ranging from $153 \mathrm{~kJ} /$ ATP for cysteine, to $99 \mathrm{~kJ} /$ ATP for glutamate. For glucose, this value is $91 \mathrm{~kJ} / \mathrm{ATP}(37)$.

\section{Amino acids}

Metabolites, including certain amino acids contribute to the perception of postprandial satiety. Mellinkoff suggested already in 1956 a relationship between serum amino acid concentration and fluctuations in appetite. They also assessed the effect of amino acid and glucose ingestion on arteriovenous blood sugar concentration and appetite in rats (38). The theory is termed the aminostatic hypothesis. Whether induced by feeding of protein or amino acids, or by infusing amino acid mixtures, a rise in the serum amino acid concentration appeared to be accompanied by a waning of appetite. The subsequent increase in appetite was accompanied by a fall in the amino acid concentration (38).

Mellinkoff has suggested that an elevated concentration of blood or plasma amino acids, which cannot be channeled into protein synthesis, may serve as a satiety signal for a food intake regulating mechanism and thereby result in depressed food intake.

Since amino acid concentrations were correlated with a reduction in appetite, Mellinkoff believed these to be connected to a 'satiety center' in the brain. In this hypothesis, the center is sensitive to serum amino acid levels and once levels reach a certain point, hunger would cease. It would seem to make sense that the control of amino acids would be a priority considering their importance for tissue growth and maintenance coupled with their potential for toxicity at very high levels. With respect to central regulation, Nefti et al. showed that protein-induced satiety was related to vagal feedback to (i) the nucleus tractus solitarius in the brainstem, where it represents satiety at almost a reflex level, and (ii) the hypothalamus, where it suppresses feelings of hunger (39). 


\section{Gluconeogenesis}

At last, the mechanism of gluconeogenesis has been mentioned to contribute to satiety, or better food intake regulation, yet until now this only has been shown in the animal model (3). The satiating effect of high protein feeding could be related to the improvement of glucose homeostasis through the modulation of hepatic gluconeogenesis and subsequent glucose metabolism (3).

\section{ROLE OF TYPE OF PROTEIN IN PROTEIN-INDUCED SATIETY BY ACUTE HIGH PROTEIN MEALS}

Different proteins may affect satiety differently. This has been shown especially with respect to whey and casein protein. Different proteins appear to imply different satiety mechanisms, and indeed, the different mechanisms appear to be related mainly to different nutrients (40-42).

Lang et al. did not observe significant differences in energy intake or macronutrient intake at dinner or over $24 \mathrm{~h}$ after a test lunch with casein, gelatin, or soy protein (43). Neither did they observe significantly different effects of egg albumin, casein, gelatin, soy, pea, or wheat gluten on appetite scores or energy intake (44). One problem with these studies is that not always single proteins are used, so results are not completely representative of the actual protein being investigated. The other problem is that dinner was offered $8 \mathrm{~h}$ after lunch, so the differences in satiety may have diminished by this time.

Hall et al. report a significantly lower energy intake following a whey protein preload compared with a casein preload. The buffet meal however was offered at 90 minutes after the preloads, which probably is too soon for casein to be a realistic and sensitive moment (25). Bowen et al. $(24,45)$ compared energy intake, ghrelin, and cholecystokinin after different carbohydrate and protein preloads in overweight men. They did not find effects from different proteins i.e. casein and whey, yet they again observed that high protein meals induced a larger satiating effect than high carbohydrate meals. Furthermore, they noted different appetite regulatory hormone responses to various dietary proteins, i.e. after whey, soy, or gluten preload, by differences in body mass index status despite similar reductions in ad libitum energy intake (45).

Therefore, until now hardly any clear differences in satiating properties between different protein types are shown, mainly due to the design of the study, using not just one single protein $(43,44)$, or to the timing, so that slow proteins do not get a chance to show effects $(25,43,44)$, or to very high amounts of protein given, so that all meals are quite satiating and not discriminative anymore.

An important issue to be taken into account is timing, due to marked differences in protein kinetics. In their review on whey proteins in the regulation of food intake and satiety (46), Luhovyy, Akhavan, and Anderson showed that timing is essential. One may use the satiating power of a high protein meal optimally when timing of the meal interval synchronizes with timing of the amino acid profiles (46).

Veldhorst et al. $(42,47)$ conducted a series of studies on effects of different types of protein (casein, soy, whey, and whey without GMP: Glycomacropeptide) ingestion, each in two different quantities ( $10 \%$ and $25 \%$ of energy from the single protein type). They discovered that outcomes differed due to type or quantity of protein intake, or both. For instance, with whey as a single protein in a subject specifically standardized custard breakfast, energy intake at lunch, $3 \mathrm{~h}$ after 
a breakfast with whey still containing GMP compared to energy intake after a breakfast with whey without GMP, was decreased by $13 \%$ irrespective of the whey protein content being 10 or $25 \%$ of energy in the custard breakfast (47).

Also Burton-Freeman (48) investigated the role of GMP in whey protein-induced satiety, as measured by subjective satiety, CCK release and food intake at a test meal in healthy weight men and women. Twenty subjects ( $n=10$ men, 10 women) consumed 1 of 4 preload shakes (300 $\mathrm{mL}, 1 \mathrm{MJ}), 1$ week apart. Preloads differed by protein source and content: whey; whey protein isolate, Whey(-)GMP; whey protein without GMP, control; low protein, GMP; GMP isolate. Protein energy of preloads was $44,44,2$ and $3 \%$, respectively, and a lunch test meal was provided at $75 \mathrm{~min}$. They observed that pre-meal satiety was greater after whey protein preloads compared to control and GMP preloads in women, but no difference was evident in men. CCK concentrations followed a pattern that predicted the subjective satiety in women, but not in men. Test meal intake was not different by preload; however, compensation relative to usual daily intake was achieved after whey-containing- and GMP-containing preloads in women and after GMP and control preloads in men. They conclude that GMP alone is not critical in premeal whey-induced satiety; however, they suggest that it may have a unique role in compensatory intake regulation managing daily energy intake (48). The latter is in line with the observation in the study by Veldhorst et al. (47) who did find an effect on food intake at lunch, 3 $\mathrm{h}$ after the whey containing breakfast.

Also, Veldhorst et al. observed that the higher percentage of whey-protein present in the custard triggered relatively stronger hormone responses. After both $25 \mathrm{En} \%$ as compared with 10 En\% whey-breakfasts GLP-1 $(p<0.05)$ and insulin $(p<0.001)$ concentrations were higher whereas ghrelin $(p<0.01)$ concentrations were lower. However, this was neither related to satiety, nor to subsequent energy intake (47). Similarly, Burton-Freeman found that after the whey containing preloads, CCK concentrations followed a pattern that predicted the subjective satiety in women, but not in men. Here also no mathematical relationship between satiety and relevant hormone responses was reported (48).

Moreover Veldhorst et al. analysed postprandial amino acid concentrations in the blood as well. They conclude that GMP as a whey-fraction reduced energy intake coinciding with increased concentrations of certain amino acids, e.g. serine, threonine, alanine, and isoleucine. Between different concentrations of whey-protein significant differences in hormone responses were present, yet these were unrelated to satiety or energy intake (47). Similarly, they assessed effects after ingesting casein, or soy as the only protein component in the breakfast. Higher satiating effects due to higher concentrations of casein or soy ( $25 \mathrm{En} \%$ vs. $10 \mathrm{En} \%$ ) were related to amino acid profiles and their timing (42).

Also with respect to type of protein, especially regarding biopeptides, or fractions of protein, Pichon et al. (49) compared effects of different fractions of whey proteins: milk, whey and $\beta$-lac. They observed that food intake and body weight gain were significantly lower in rats fed the diet containing $\beta$-lac, which was unrelated to palatability (49).

Further assessment of the role of biopeptides in postprandial protein-induced satiety in humans was executed by Diepvens et al. (41). They investigated the effects of whey protein (WP), pea protein hydrolysate (PPH), a combination of WP+PPH, and control (milk protein, MP) on appetite ratings, postprandial changes in hunger/satiety hormones and energy intake, in a randomized, crossover design, in 39 overweight subjects. Indications of lower hunger and desire to eat were 
shown after consumption of PPH compared to MP or WP+PPH $(\mathrm{p}<0.05)$. A longer intermeal interval and a greater satiety were suggested after consumption of PPH. Both PPH and WP lead to greater satiety and fullness compared to MP and WP+PPH $(p<0.05)$. Again, effects on relevant hormones were primarily nutrient related. CCK and GLP-1 concentrations were relatively more increased by MP $(p<0.05)$ while PYY concentrations were relatively more elevated and ghrelin concentrations more reduced by WP+PPH $(p<0.05)$. No effect on energy intake was seen. They conclude that there was modest evidence with respect to satiety by PPH consumption (41).

Taken together, when considering different proteins or biopeptides, magnitudes in satiety differ (42, 46-49), mainly coinciding with increased amino acid concentrations $(42,46,47)$. Roles of (an)orexigenic hormones may be a nutrient-specific support of satiety, yet cannot be taken mathematically as a proxy, since they assume a linearity in relationships that are not even present $(41,46-48)$.

\section{IMPLICATIONS OF PROTEIN INDUCED SATIETY DURING WEIGHT LOSS AND WEIGHT MAINTENANCE THEREAFTER}

From weight-loss studies, it appears that larger body weight loss on a sustained relatively high protein diet depends on high protein diet-induced satiety, energy expenditure, and sparing fat free mass (3). Under iso-energetic conditions no statistically significant difference between body weight loss on a high protein or high carbohydrate diet was shown. Still, those studies show an improved body composition (i.e. an increased fat free mass/ fat mass ratio) and metabolic profile with a relatively high protein diet $(50,51)$. The relatively high protein diets all consist of $25-30 \%$ of energy from protein implying a sustained normal protein intake in grams, while energy intake is decreased.

Thus effects on energy expenditure and lean body mass are present when the high protein diet is consumed iso-energetically with the control diet, indicating the importance of those factors (3). However, body weight loss is greater under conditions of ad libitum energy intake than under conditions of iso-energetic diets. The explanation for this is that satiety is a key factor in applying high protein diets. Under ad libitum conditions subjects eat less from a high protein diet than under iso-energetically fed conditions (52-54). Such diets contain a sufficient absolute amount of protein but lead to decreased energy intake, suggesting that in addition to metabolic effects of protein on body weight loss, energy intake plays an important role. Weigle et al. (54) showed that a high protein diet has a greater satiating effect (30/50/20 energy percent protein/carbohydrate/fat, $\sim 180 \mathrm{~g}$ protein) than an iso-energetic normal protein diet (15/50/35\% of energy from protein/carbohydrate/fat, 90 g protein) when fed for 2 weeks in energy balance of $\sim 10 \mathrm{MJ} / \mathrm{d}$. Thereafter, a reduction in energy intake of $\sim 2 \mathrm{MJ} / \mathrm{d}$ was observed when the high protein diet was offered ad libitum, whilst sustaining the previous level of satiety. Although the diet remained relatively high in protein (30\% energy), the absolute amount of protein was still high enough ( $\sim 144 \mathrm{~g}$ ) to sustain satiety at the original (and probably desired) level, despite a reduction in energy intake. Reduction of fat intake during the high protein intake may have contributed to the effect on body-weight, partly through reduction of energy density. However, this cannot be concluded from the actual experiment (54). 
Relatively high protein diets consumed ad libitum also can promote weight maintenance. For example, overweight to moderately obese men and women who had recently lost weight (7.5 $\pm 2.0 \%$ body weight loss over 4 weeks) who consumed $18 \%$ of energy intake as protein, regained less weight $(1 \mathrm{~kg}$ ) after 3 months, compared to those consuming $15 \%$ of energy as protein (weight regain $2 \mathrm{~kg}$ ) (17). This was not a consequence of possible differences in dietary restraint or in physical activity between the high protein and the control group, indicating a metabolic effect of protein. The composition of the body mass regained was more favorable in the higher protein group (i.e. no regain of fat mass, but only of fat free mass resulting in a lower percentage body fat). Leptin concentrations from fasting blood samples during weight regain increased significantly slower in the higher protein group, and only in the control group the increase of leptin was related to the increase in fat mass. Moreover, metabolic risk characteristics were reduced in the higher protein group and energy efficiency ( $\mathrm{kg}$ body mass regain/energy intake) was significantly lower in the higher protein group. The observations with respect to energy efficiency during weight regain were comparable to the 'Stock hypothesis' described for weight gain $(17,55)$.

With a similar design as the previously mentioned weight maintenance study by WesterterpPlantenga et al. (17), Lejeune and colleagues demonstrated a weight 'regain' of $0.8 \mathrm{~kg}$ (high protein group) vs. $3.0 \mathrm{~kg}$ (control group) $(\mathrm{p}<0.05)$ after 6 months on a weight maintenance diet (18). During follow-up of 1 year after the weight loss program, these figures were $1.0 \mathrm{~kg}$ vs. 3.9 $\mathrm{kg}(\mathrm{p}<0.05)(18)$. Thus evidence shows that a relatively high protein intake sustains weight maintenance by (i) favoring regain of fat free mass at the cost of fat mass at a similar physical activity level, (ii) reducing the energy efficiency with respect to the body mass regained, and (iii) increasing satiety (17).

Taken together, relative high protein diets, offered ad libitum, whereby the absolute amount of protein as consumed before dieting is sustained, promote weight loss as well as weight maintenance. It remains to be assessed whether and how types of protein contribute differently to this phenomenon.

\section{ADVERSE EVENTS}

During long-term consumption of high protein diets, in the absolute sense, i.e. in grams, may have adverse effects on the kidney, and therefore finally on blood pressure. However, different amino acids may have opposing effects, dependent on whether they are involved in gluconeogenesis and/or ureagenesis or whether they are acidifying. Amino acids involved in gluconeogenesis and/or ureagenesis may have a blood pressure lowering effect, whereas acidifying amino acids may have a blood-pressure raising effect. Subjects with subclinical renal injury, such as elderly subjects, subjects with low renal functional mass such as renal transplant recipients, and subjects with obesity-related conditions, such as metabolic syndrome and type 2 diabetes, will be more susceptible to the blood pressure raising effects than others.

Especially sulphur-containing amino acids (cysteine, homocysteine, methionine, taurine) may compromise long-term renal maintenance of acid-base homeostasis, and cause a blood-pressure raising effect $(56,57)$. Then acid-base homeostasis is maintained through excretion of the excess acid load by the kidneys. The kidneys compensate by increased excretion of ammonia, resulting 
from stimulated ammoniagenesis, with the amino acid glutamine as substrate $(56,57)$. Chronic ingestion of large amounts of sulphur-containing amino acids may have an indirect effect on blood pressure by induction of renal subtle structural damage, ultimately leading to loss of nephron mass, and a secondary increase in blood pressure $(58,59)$. The established synergy between obesity and low nephron number on induction of high blood pressure and further decline of renal function identifies subjects with obesity, metabolic syndrome and type 2 diabetes as particularly susceptible groups $(60,61)$.

\section{CONCLUSION}

Protein-induced satiety has been shown acutely, with single meals, with contents of $25 \%$ to $81 \%$ of energy from protein in general or from specific proteins, while subsequent energy intake reduction was significant.

Protein-induced satiety has been shown with high protein ad libitum diets, lasting from 1 to 6 days, up to 6 months. After a high protein ad libitum diet significantly greater weight loss has been observed, in comparison with control.

Mechanisms explaining protein-induced satiety are primarily nutrient-specific, and consist mainly of coincidence, or synchronization or a relationship with elevated amino acid concentrations.

Different proteins cause different nutrient related responses of (an)orexigenic hormones. GLP-1 release evoked by a high protein meal is stimulated by the carbohydrate content. Also PYY release is stimulated by a high protein meal. Ghrelin does not seem to be affected by a high protein meal or diet, and little information is available on CCK. Although anorexigenic hormones support satiety nutrient specifically, usually they are not mathematically related to satiety.

During high protein diets, protein-induced satiety is related to protein-induced energy expenditure. Finally, protein-induced satiety appears to be of vital importance for weight loss and weight maintenance.

With respect to possible adverse events chronic ingestion of large amounts of sulphurcontaining amino acids may have an indirect effect on blood pressure by induction of renal subtle structural damage, ultimately leading to loss of nephron mass, and a secondary increase in blood pressure. The established synergy between obesity and low nephron number on induction of high blood pressure and further decline of renal function identifies subjects with obesity, metabolic syndrome and diabetes mellitus 2 as particularly susceptible groups.

\section{REFERENCES}

1. Seidell JC. Obesity in Europe. Obes Res 1995;3 Suppl 2:89s-93s.

2. Pi-Sunyer FX. Medical hazards of obesity. Ann Intern Med 1993;119:655-60.

3. Westerterp-Plantenga MS, Luscombe-Marsh ND, Lejeune MPGM, et al. Dietary protein, metabolism, and bodyweight regulation: dose-response effects. IJO 2006;30:S16-S23.

4. Evaluation of certain food additives and contaminants. World Health Organ Tech Rep Ser 2000;896:1-128.

5. Hulshof KFAM, Ocke MC, van Rossum CTM, Buurma-Rethans EJM, Brants HAM, Drijvers JJMM. Results of the food consumption survey 2003. Bilthoven/ Zeist: RIVM/ TNO, 2004. 
Wright JD, Kennedy-Stephenson J, Wang CY, McDowell MA, Johnson CL. Trends in intake of energy and macronutrients-United States, 1971-2000. JAMA 2004;291:1193-1194.

McLennan W, Podger A. National Nutrition Survey: nutrient intakes and physical measurements. Australian Bureau of Statistics, 1998.

Nutrition profile of the South-East Asia region New Delphi: World Health Organization, 2000.

Division FS. http://www.fao.org/es.ess.faostat/foodsecurity/index. FAO Statistics Division.

Westerterp-Plantenga MS. How are normal, high- or low-protein diets defined? Br J Nutr 2007;97:217-8

Westerterp-Plantenga MS, Rolland V, Wilson SA, Westerterp KR. Satiety related to $24 \mathrm{~h}$ diet-induced thermogenesis during high protein/carbohydrate vs high fat diets measured in a respiration chamber. Eur J Clin Nutr 1999;53:495-502.

Latner JD, Schwartz M. The effects of a high-carbohydrate, high-protein or balanced lunch upon later food intake and hunger ratings. Appetite 1999;33:119-28.

Eisenstein J, Roberts SB, Dallal G, Saltzman E. High-protein weight-loss diets: are they safe and do they work? A review of the experimental and epidemiologic data. Nutr Rev 2002;60:189-200.

Barkeling B, Rossner S, Bjorvell H. Effects of a high-protein meal (meat) and a high-carbohydrate meal (vegetarian) on satiety measured by automated computerized monitoring of subsequent food intake, motivation to eat and food preferences. Int J Obes 1990;14:743-51.

Hill AJ, Blundell JE. Macronutrients and satiety: the effects of high carbohydrate and high protein meals on subjective motivation to eat and preferences. Nutr Behav 1986;3:133-44.

Smeets AJ, Soenen S, Luscombe-Marsh ND, Ueland O, Westerterp-Plantenga MS. Energy expenditure, satiety, and plasma ghrelin, glucagon-like peptide 1 , and peptide tyrosine-tyrosine concentrations following a single high-protein lunch. J Nutr 2008;138:698-702.

Westerterp-Plantenga MS, Lejeune MP, Nijs I, van Ooijen M, Kovacs EM. High protein intake sustains weight maintenance after body weight loss in humans. Int J Obes Relat Metab Disord 2004;28:57-64.

Lejeune MP, Kovacs EM, Westerterp-Plantenga MS. Additional protein intake limits weight regain after weight loss in humans. Br J Nutr 2005;93:281-9.

Lejeune MP, Westerterp KR, Adam TC, Luscombe-Marsh ND, Westerterp-Plantenga MS. Ghrelin and glucagonlike peptide 1 concentrations, 24-h satiety, and energy and substrate metabolism during a high-protein diet and measured in a respiration chamber. Am J Clin Nutr 2006;83:89-94.

Stubbs RJ, van Wyk MC, Johnstone AM, Harbron CG. Breakfasts high in protein, fat or carbohydrate: effect on within-day appetite and energy balance. Eur J Clin Nutr 1996;50:409-17.

Crovetti R, Porrini M, Santangelo A, Testolin G. The influence of thermic effect of food on satiety. Eur J Clin Nutr 1998;52:482-8.

Johnson J, Vickers Z. Effects of flavor and macronutrient composition of food servings on liking, hunger and subsequent intake. Appetite 1993;21:25-39.

Westerterp-Plantenga MS, Lejeune MP, Smeets AJ, Luscombe-Marsh ND. Sex differences in energy homeostatis following a diet relatively high in protein exchanged with carbohydrate, assessed in a respiration chamber in humans. Physiol Behav 2009;97:414-9.

Bowen J, Noakes M, Trenerry C, Clifton PM. Energy intake, ghrelin, and cholecystokinin after different carbohydrate and protein preloads in overweight men. J Clin Endocrinol Metab 2006;91:1477-83.

Hall WL, Millward DJ, Long SJ, Morgan LM. Casein and whey exert different effects on plasma amino acid profiles, gastrointestinal hormone secretion and appetite. Br J Nutr 2003;89:239-48.

van Loon $\amalg$, Saris WH, Verhagen H, Wagenmakers AJ. Plasma insulin responses after ingestion of different amino acid or protein mixtures with carbohydrate. Am J Clin Nutr 2000;72:96-105.

Batterham RL, Heffron H, Kapoor S, et al. Critical role for peptide YY in protein-mediated satiation and bodyweight regulation. Cell Metab 2006;4:223-33.

Westerterp-Plantenga MS, Westerterp KR, Rubbens M, Verwegen CR, Richelet JP, Gardette B. Appetite at "high altitude" [Operation Everest III (Comex-'97)]: a simulated ascent of Mount Everest. J Appl Physiol 1999;87:3919. Livesey G. A perspective on food energy standards for nutrition labelling. Br J Nutr 2001;85:271-87.

Tappy L. Thermic effect of food and sympathetic nervous system activity in humans. Reprod Nutr Dev 1996;36:391-7.

Westerterp KR, Wilson SA, Rolland V. Diet induced thermogenesis measured over $24 \mathrm{~h}$ in a respiration chamber: effect of diet composition. Int J Obes Relat Metab Disord 1999;23:287-92.

Tessari P, Kiwanuka E, Zanetti M, Barazzoni R. Postprandial body protein synthesis and amino acid catabolism measured with leucine and phenylalanine-tyrosine tracers. Am J Physiol Endocrinol Metab 2003;284:E1037-42. van Milgen J. Modeling biochemical aspects of energy metabolism in mammals. J Nutr 2002;132:3195-202.

Boirie Y, Dangin M, Gachon P, Vasson MP, Maubois JL, Beaufrere B. Slow and fast dietary proteins differently modulate postprandial protein accretion. Proc Natl Acad Sci U S A 1997;94:14930-5.

Dangin M, Boirie Y, Garcia-Rodenas C, et al. The digestion rate of protein is an independent regulating factor of postprandial protein retention. Am J Physiol Endocrinol Metab 2001;280:E340-8.

Dangin M, Boirie Y, Guillet C, Beaufrere B. Influence of the protein digestion rate on protein turnover in young and elderly subjects. J Nutr 2002;132:3228S-33S. 
37. Stryer L. Biochemistry. New York: W.H. Freeman and Company, 1988.

38. Mellinkoff SM, Frankland M, Boyle D, Greipel M. Relationship between serum amino acid concentration and fluctuations in appetite. J Appl Physiol 1956;8:535-8.

39. Nefti W, Darcel N, Fromentin G, Tome D. Long-term exposure to high-protein diet or high-fat diet have opposite effects on vagal afferent sensitivity to luminal macronutrients, ip cholecystokinin and serotonin. Appetite 2007;49:316.

40. Anderson GH, Tecimer SN, Shah D, Zafar TA. Protein source, quantity, and time of consumption determine the effect of proteins on short-term food intake in young men. J Nutr 2004;134:3011-5.

41. Diepvens K, Haberer D, Westerterp-Plantenga M. Different proteins and biopeptides differently affect satiety and anorexigenic/orexigenic hormones in healthy humans. Int J Obes (Lond) 2008;32:510-8.

42. Veldhorst MAB, Nieuwenhuizen A, Hochstenbach-Waelen A, et al. Effects of high or normal casein-, soy-, or whey with or without GMP- protein breakfasts on satiety, 'satiety' hormones, and plasma amino acid responses. Appetite 2007;49:336.

43. Lang V, Bellisle F, Alamowitch C, et al. Varying the protein source in mixed meal modifies glucose, insulin and glucagon kinetics in healthy men, has weak effects on subjective satiety and fails to affect food intake. Eur J Clin Nutr 1999;53:959-65.

44. Lang V, Bellisle F, Oppert JM, et al. Satiating effect of proteins in healthy subjects: a comparison of egg albumin, casein, gelatin, soy protein, pea protein, and wheat gluten. Am J Clin Nutr 1998;67:1197-204.

45. Bowen J, Noakes M, Clifton PM. Appetite regulatory hormone responses to various dietary proteins differ by body mass index status despite similar reductions in ad libitum energy intake. J Clin Endocrinol Metab 2006;91:2913-9.

46. Luhovyy BL, Akhavan T, Anderson GH. Whey proteins in the regulation of food intake and satiety. J Am Coll Nutr 2007;26:704S-12S.

47. Veldhorst MAB, Nieuwenhuizen A, Hochstenbach-Waelen A, et al. Effects of high and normal whey with or without GMP- protein breakfasts on amino acid, satiety, 'satiety' hormone responses and energy intake. Submitted.

48. Burton-Freeman BM. Glycomacropeptide (GMP) is not critical to whey-induced satiety, but may have a unique role in energy intake regulation through cholecystokinin (CCK). Physiol Behav 2008;93:379-87.

49. Pichon $L$, Potier $M$, Tome $D$, et al. High-protein diets containing different milk protein fractions differently influence energy intake and adiposity in the rat. Br J Nutr 2008;99:739-48.

50. Johnston CS, Tjonn SL, Swan PD. High-protein, low-fat diets are effective for weight loss and favorably alter biomarkers in healthy adults. J Nutr 2004;134:586-91.

51. Layman DK, Boileau RA, Erickson DJ, et al. A reduced ratio of dietary carbohydrate to protein improves body composition and blood lipid profiles during weight loss in adult women. J Nutr 2003;133:411-7.

52. Dumesnil JG, Turgeon J, Tremblay A, et al. Effect of a low-glycaemic index--low-fat--high protein diet on the atherogenic metabolic risk profile of abdominally obese men. Br J Nutr 2001;86:557-68.

53. Skov AR, Toubro S, Ronn B, Holm L, Astrup A. Randomized trial on protein vs carbohydrate in ad libitum fat reduced diet for the treatment of obesity. Int J Obes Relat Metab Disord 1999;23:528-36.

54. Weigle DS, Breen PA, Matthys CC, et al. A high-protein diet induces sustained reductions in appetite, ad libitum caloric intake, and body weight despite compensatory changes in diurnal plasma leptin and ghrelin concentrations. Am J Clin Nutr 2005;82:41-8.

55. Stock MJ. Gluttony and thermogenesis revisited. Int J Obes Relat Metab Disord 1999;23:1105-17.

56. Frassetto LA, Morris RC, Jr., Sebastian A. A practical approach to the balance between acid production and renal acid excretion in humans. J Nephrol 2006;19 Suppl 9:S33-40.

57. Remer T. Influence of nutrition on acid-base balance--metabolic aspects. Eur J Nutr 2001;40:214-20.

58. Hoy WE, Hughson MD, Bertram JF, Douglas-Denton R, Amann K. Nephron number, hypertension, renal disease, and renal failure. J Am Soc Nephrol 2005;16:2557-64.

59. Keller G, Zimmer G, Mall G, Ritz E, Amann K. Nephron number in patients with primary hypertension. N Engl J Med 2003;348:101-8.

60. Bagby SP. Maternal nutrition, low nephron number, and hypertension in later life: pathways of nutritional programming. J Nutr 2007;137:1066-72.

61. Praga M. Synergy of low nephron number and obesity: a new focus on hyperfiltration nephropathy. Nephrol Dial Transplant 2005;20:2594-7. 
Chapter 3

\section{Comparison of the effects of a high- and normal-casein breakfast on satiety, 'satiety' hormones, plasma amino acids and subsequent energy intake}

Veldhorst MAB, Nieuwenhuizen AG, Hochstenbach-Waelen A, Westerterp KR, Engelen MPKJ, Brummer RJM, Deutz NEP, Westerterp-Plantenga MS

Br J Nutr 2009; 101 (2): 295-303 


\section{ABSTRACT}

The present study compared the effects of a high- and normal casein-protein breakfast on satiety, 'satiety' hormones, and plasma amino acid responses and subsequent energy intake. Twenty-five healthy subjects (mean \pm SEM BMI: $23.9 \pm 0.3 \mathrm{~kg} / \mathrm{m}^{2}$; age: $22 \pm 1$ years) received a subject-specific standardized breakfast ( $20 \%$ of daily energy requirements): a custard with casein as single protein source with either 10/55/35 (normal) or 25/55/20 (high) En\% protein/carbohydrate/fat in a randomized, single-blind design. Appetite profile (Visual Analogue Scale, VAS), plasma glucose, insulin, Glucagon-like Peptide 1 (GLP-1), ghrelin, and amino acid (AA) concentrations were determined for four hours; here the sensitive moment in time for lunch was determined. Subjects came for a second set of experiments and received the same custards for breakfast, an ad lib lunch was offered at 180 minutes after breakfast; energy intake (EI) was assessed. There were increased scores of fullness and satiety after the $25 \mathrm{En} \%$ caseincustard compared with the $10 \mathrm{En} \%$ casein-custard; particularly at $180(26 \pm 4$ mmVAS vs. $11 \pm 5$ mmVAS, $P<0.01)$ and 240 minutes $(13 \pm 5$ mmVAS vs. $-1 \pm 5$ mmVAS, $P<0.01)$. This coincided with prolonged elevated plasma AA concentrations; total AA and branched-chain AA were higher after $25 \mathrm{En \%}$ compared with $10 \mathrm{En} \%$ at 180 and 240 minutes $(P<0.001)$. There was no difference in $\mathrm{El}(25 \mathrm{En} \%: 3080 \pm 229 \mathrm{~kJ}$ vs. $10 \mathrm{En} \% 3133 \pm 226 \mathrm{~kJ}, \mathrm{~ns})$ from the ad lib lunch. In conclusion, a breakfast with $25 \%$ of energy from casein is rated as being more satiating than a breakfast with $10 \%$ of energy from casein at three and four hours after breakfast coinciding with prolonged elevated concentrations of plasma amino acids but does not reduce subsequent energy intake.

KEYWORDS: $\quad$ satiety, energy intake, casein protein, glucagon-like peptide 1, ghrelin, protein kinetics 


\section{INTRODUCTION}

The increasing incidence of obesity is considered as a major health problem due to its comorbidity of a number of diseases, including diabetes mellitus type 2, cardiovascular disease, and certain types of cancer $(1,2)$. Obesity is the result of a positive energy balance due to energy intake exceeding energy expenditure. In the system of body weight regulation several pathways are involved and therefore weight management requires a multi-factorial approach (3). Recent findings suggest that a relatively elevated protein intake seems to play a role during weight loss as well as during weight maintenance thereafter (4-7). In addition to the protein-induced satiety that has been shown after a high protein diet, protein-induced satiety has also been shown after a single meal (8-10). Several studies on different types of protein affecting satiety have been executed (11-16). The question remains however whether the larger satiating effects of high protein meals hold for each specific type of protein.

Casein is a part of milk protein, it comprises $80 \%$ of the protein content of bovine milk (17). Casein is considered as a 'slow' protein because it coagulates in the stomach and delays gastric emptying (18). The slower digestion rate of casein results in smaller but prolonged increased postprandial plasma amino acid levels $(18,19)$. If the extent of postprandial increase in circulating amino acids influences satiety, as was hypothesized by the amino static theory of Mellinkoff (20), consumption of different levels of casein-protein in a single meal should result in differences in subsequent satiety. We investigated possible differences in satiety ratings between a high and a normal casein-protein concentration and the mechanisms accompanying those differences. Casein was offered in a breakfast consisting of $20 \%$ of the subject-specific daily energy requirements, with amounts of casein that represent the highest allowed protein intake per day, i.e. $25 \%$ of energy from protein versus the lowest (normal) protein intake per day, $10 \%$ of energy from protein (21). Protein was exchanged with fat; carbohydrate content was kept constant at a level of $55 \mathrm{En} \%$ because its effects on protein metabolism (22), resulting in a comparison of a high protein-low fat breakfast with a normal protein-normal fat breakfast with casein as single protein type.

The aim of the present study was to compare the effects of a high versus a normal amount of casein-protein containing breakfast on plasma amino acid concentrations, appetite profile, such as ratings of hunger, satiety, fullness, and desire to eat, plasma glucose, and possibly related plasma hormone levels of insulin, Glucagon-like Peptide 1 (GLP-1), and ghrelin and subsequent energy intake. In order to determine the moment in time that may be sensitive to show a possible difference in food intake we first assessed appetite profile ratings and 'satiety' hormones for four hours and in the subsequent experiment energy intake was measured at the determined moment in time.

\section{SUBJECTS AND METHODS}

\section{Subjects}

Thirty healthy male and female volunteers (Body Mass Index $22-30 \mathrm{~kg} / \mathrm{m}^{2}$, age $18-40$ years) were recruited by advertisements in local newspapers and on notice boards at the university. They 
underwent a screening including medical history, measurement of body weight and height and cognitive restrained eating using a Dutch translation of the Three Factor Eating Questionnaire (TFEQ) $(23,24)$. Twenty-five subjects (11 male, 14 female) were selected on being in good health, non-smokers, non-vegetarian, not cognitively dietary restraint, not using medication apart from oral contraceptives and at most moderate alcohol users. Their mean age was $22 \pm 1$ year, and their body weight was $74.4 \pm 1.8 \mathrm{~kg}$ (BMl: $23.9 \pm 0.3 \mathrm{~kg} / \mathrm{m}^{2}$ ). A written informed consent was obtained from these participants and the study protocol was approved by the Medical Ethical Committee of the Academic Hospital Maastricht.

\section{Study design}

A randomized, single blind, within-subject experimental study was performed. All subjects came to the university on two occasions, separated by at least one week. On each test day subjects received a subject-specific standardized breakfast and appetite ratings and blood parameters were obtained for four hours after breakfast.

After two months, when the sensitive moment in time was determined based on appetite profile ratings and concentrations of metabolites, subjects again came to the university on two occasions in a randomized, single blind design, separated by at least one week. On each test day subjects received a subject-specific standardized breakfast and an ad lib lunch was offered at the previously determined sensitive moment in time.

\section{Breakfast}

Breakfast was offered as a custard with casein (Calcium Caseinate S, DMV International Veghel, The Netherlands) as a single protein source, with either protein/carbohydrate/fat: 10/55/35 En\% (normal protein) or protein/carbohydrate/fat: 25/55/20 En\% (high protein). The breakfast contained $20 \%$ of daily energy requirements, calculated as basal metabolic rate (BMR), according to the equations of Harris-Benedict, multiplied by an activity index of 1.75 (25). The mean energy content of the breakfast was $2.52 \pm 0.07 \mathrm{MJ}$ and the provided breakfasts were completely finished.

The custards were produced by NIZO Food Research bv. (Ede, The Netherlands) and had tapioca starch (Farinex VA50T, AVEBE, Veendam, The Netherlands and Perfectamyl 3108 AVEBE, Veendam, The Netherlands) and sunflower oil (Reddy, NV Vandemoortele, Roosendaal, The Netherlands) respectively as carbohydrate and fat source and were citrus-vanilla (Citrus, J.B. de lange, Belfeld, The Netherlands; Vanilla, J.B. de lange, Belfeld, The Netherlands) flavoured. Extensive product development and use of a taste panel lead to custards that did not differ significantly in colour, taste, or viscosity. The amino acid composition of the custards is presented in table 1.

Lunch

Lunch consisted of Turkish bread (400 g) with egg salad (400 g) with 13/41/46 En\% protein/carbohydrate/fat with an energy density of $11.4 \mathrm{~kJ} / \mathrm{g}$. Subjects were instructed to eat till they were comfortably full. 
Table 1 Amino acid content of the breakfasts given as a custard with either $10 \%$ of energy from casein-protein or $25 \%$ of energy from casein-protein ( $g$ amino acids/100 $g$ custard)

\begin{tabular}{lcc}
\hline & $\begin{array}{c}\text { casein } \\
\text { 10\% of energy }\end{array}$ & $\begin{array}{c}\text { casein } \\
25 \% \text { of energy }\end{array}$ \\
Glutamic acid $^{*}$ & & \\
Aspartic acid $^{+}$ & 0.477 & 1.127 \\
Cysteine $^{*}$ & 0.150 & 0.355 \\
Serine & 0.009 & 0.021 \\
Histidine & 0.120 & 0.283 \\
Glycine & 0.064 & 0.152 \\
Threonine & 0.040 & 0.094 \\
Arginine & 0.090 & 0.214 \\
Alanine & 0.092 & 0.218 \\
Tyrosine & 0.064 & 0.150 \\
Valine & 0.120 & 0.283 \\
Methionine & 0.141 & 0.333 \\
Isoleucine & 0.064 & 0.152 \\
Phenylalanine & 0.112 & 0.265 \\
Tryptophan & 0.110 & 0.259 \\
Leucine $_{\text {Lysine }}$ & 0.027 & 0.064 \\
Proline & 0.204 & 0.483 \\
& 0.172 & 0.405 \\
\hline
\end{tabular}

* Glutamic acid = glutamine + glutamate

${ }^{+}$Aspartic acid $=$asparagine

\section{Study protocol}

The protocol started at $08.00 \mathrm{~h}$ after an overnight fast from $22.00 \mathrm{~h}$. A Venflon catheter was placed in a superficial dorsal vein of the hand for blood sampling. To obtain arterialized venous blood samples the hand was placed in a thermostatically controlled hot box at $60^{\circ} \mathrm{C}$ for 20 minutes before the sampling time. A basal blood sample was taken and appetite ratings were scored. After 5 minutes a second basal blood sample was obtained and breakfast was offered ( $\mathrm{t}=0$ minutes) and completed within 20 minutes. After the first and the last bite, taste perception was scored. Appetite ratings were completed just before breakfast and at 20,40,60, 80, 100, 120, 180, and 240 minutes after breakfast. Blood samples for urea and amino acid determination were obtained at -5 minutes and subsequently at the same time points as the appetite ratings; blood samples for determination of glucose, insulin, and ghrelin concentrations were obtained before and 40,60, 120, and 180 minutes after breakfast. Venous blood samples for determination of GLP-1 concentration were obtained separately before, and at 30, 60, 90, 120 , and 180 minutes after breakfast by means of a Venflon catheter placed in an antecubital vein (26). Subjects were allowed to drink maximally two glasses of water spread over the morning.

In the second set of experiments, the protocol started after an overnight fast from $22.00 \mathrm{~h}$ at $8.30 \mathrm{~h}$ with scoring appetite ratings. Breakfast was offered ( $\mathrm{t}=0$ minutes) and completed within 20 minutes. Lunch was offered at the previously determined sensitive moment in time. Subjects were allowed to drink three glasses of water spread over the entire test period. 


\section{Measurements}

\section{Appetite profile}

To determine the appetite profile, hunger, fullness, satiety, and desire to eat were rated on 100 mm Visual Analogue Scales (VAS), anchored with 'not at all' and 'extremely' during the test day. VAS are often used to measure subjective appetite sensations and the validity and reproducibility has been shown in several studies $(27,28)$. Subjects were instructed to rate themselves by marking the scale at the point that was most appropriate to their feeling at that time. The distance from this point to the left end of the scale was measured in $\mathrm{mm}$; changes from baseline $(\Delta)$ were calculated by subtracting the baseline score ( -5 minutes) from the score at a certain time point.

\section{Taste perception}

Taste perception profiles of the custards were assessed after the first and the last bite of the breakfast using $100 \mathrm{~mm}$ Visual Analogue Scales (VAS), anchored with 'not at all' and 'extremely' on the aspects: pleasantness, sweetness, sourness, saltiness, bitterness, savouriness, crispiness, and creaminess.

\section{Energy intake}

Lunch was weighed before and after eating and energy intake was calculated by multiplying the difference of the weight of the lunch by the energy value of the lunch as determined by the product labels (11.4 kJ/g).

\section{Blood parameters}

Blood was distributed into EDTA tubes for glucose, insulin, and ghrelin measurement. For GLP-1 measurement blood was collected in EDTA tubes with added dipeptidyl peptidase IV inhibitor. For amino acid and urea determination, blood was collected in lithium heparin tubes. Blood samples were centrifuged at $4^{\circ} \mathrm{C}$ for 10 minutes at $3000 \mathrm{rpm}$. Hydrochloric acid and phenylmethylsulfonyl fluoride were added to plasma for active ghrelin determination. For amino acid analysis, $250 \mu \mathrm{l}$ plasma was deproteinized by mixing it with $20 \mathrm{mg}$ dry sulfosalicylic acid. For analysis of urea, $200 \mu \mathrm{l}$ plasma was deproteinized by mixing it with $20 \mu \mathrm{l}$ of a $500 \mathrm{~g} / \mathrm{l}$ trichloroacetic acid solution. All samples were stored at $-80^{\circ} \mathrm{C}$ until further analysis.

Plasma glucose concentrations were determined using the hexokinase method (Glucose HK 125 kit, ABX diagnostics, Montpellier, France). Insulin concentrations were measured by RIA (Linco Research Inc., St. Charles, Missouri, USA). Plasma active ghrelin concentrations were measured by ELISA (Linco Research Inc., St. Charles, Missouri, USA). Plasma active GLP-1 samples were analyzed using ELISA (EGLP-35K; Linco Research Inc., St. Charles, Missouri, USA).

Plasma concentrations of amino acids were determined with the use of a fully automated HPLC (Pharmacia, Woerden, The Netherlands), after precolumn derivatization with ophthaldialdehyde (29). Plasma urea was analyzed spectrophotometrically on a COBAS Mira S (Roche Diagnostica, Hoffman-La Roche, Basel, Switzerland). 


\section{Statistical analysis}

Data are presented as mean changes from baseline \pm standard error to the mean (SEM), unless otherwise indicated (30). The area under the curve (AUC) of changes from baseline over time (four hours for appetite ratings, amino acid and urea concentrations; three hours for glucose, insulin, GLP-1, and ghrelin concentrations) was calculated using the trapezoidal method. A repeated measures ANOVA was carried out to determine possible differences between the high and normal protein breakfast. After the second set of experiments, a repeated measures ANOVA was carried out to determine possible differences in energy intake between the breakfasts. A $P$ value $<0.05$ was regarded as statistically significant. Statistical procedures were performed using StatView 5.0 (SAS Institute Inc., USA, 1998).

\section{RESULTS}

\section{Appetite profile}

Baseline ratings for appetite scores were not different among treatments (table 2). The AUC of fullness ratings was increased after the breakfast with $25 \%$ of energy from casein compared with the breakfast with $10 \%$ of energy from casein, $8522 \pm 872$ mmVAS vs. $5459 \pm 974$ mmVAS $(P<0.01$, figure 1). Fullness ratings also were increased after a breakfast with 25 En\% casein compared with a breakfast with $10 \mathrm{En} \%$ casein at several moments in time including at 180 and 240 minutes after breakfast $(P<0.01$ and $P<0.01$, figure 1$)$. Satiety ratings were increased after the breakfast with $25 \%$ of energy from casein compared with the breakfast with $10 \%$ energy from casein at 180 and 240 minutes $(P<0.05$ and $P<0.05$, figure 1$)$.

Table 2 Baseline values of appetite profile scores ( $\mathrm{mm}$ visual analogue scale; VAS) and glucose, insulin, glucagon-like peptide (GLP-1) and ghrelin concentrations before consumption of a breakfast with either $10 \%$ of energy from casein-protein or $25 \%$ of energy from casein-protein in twenty-five subjects (men and women)*

(Mean values with their standard errors)

\begin{tabular}{lrrr} 
& $\begin{array}{c}\text { casein } 10 \% \\
\text { of energy }\end{array}$ & $\begin{array}{c}\text { casein } 25 \% \\
\text { of energy }\end{array}$ & \\
Satiety (mm VAS) & $25 \pm 4$ & $22 \pm 4$ & 0.38 \\
Fullness (mm VAS) & $24 \pm 4$ & $18 \pm 3$ & 0.13 \\
Hunger (mm VAS) & $62 \pm 4$ & $63 \pm 4$ & 0.94 \\
Desire to eat (mm VAS) & $66 \pm 4$ & $66 \pm 4$ & 0.81 \\
Glucose (mmol/l) & $5.16 \pm 0.08$ & $5.27 \pm 0.09$ & 0.26 \\
Insulin (mU/l) & $12.46 \pm 0.57$ & $4.50 \pm 2.55$ & 0.08 \\
GLP-1 (pmol/l) & $4.20 \pm 1.99$ & $9.38 \pm 1.35$ & 0.62 \\
Ghrelin (pmol/l) & $9.90 \pm 1.00$ & & 0.71 \\
& & & \\
\hline
\end{tabular}

* Repeated-measures ANOVA 

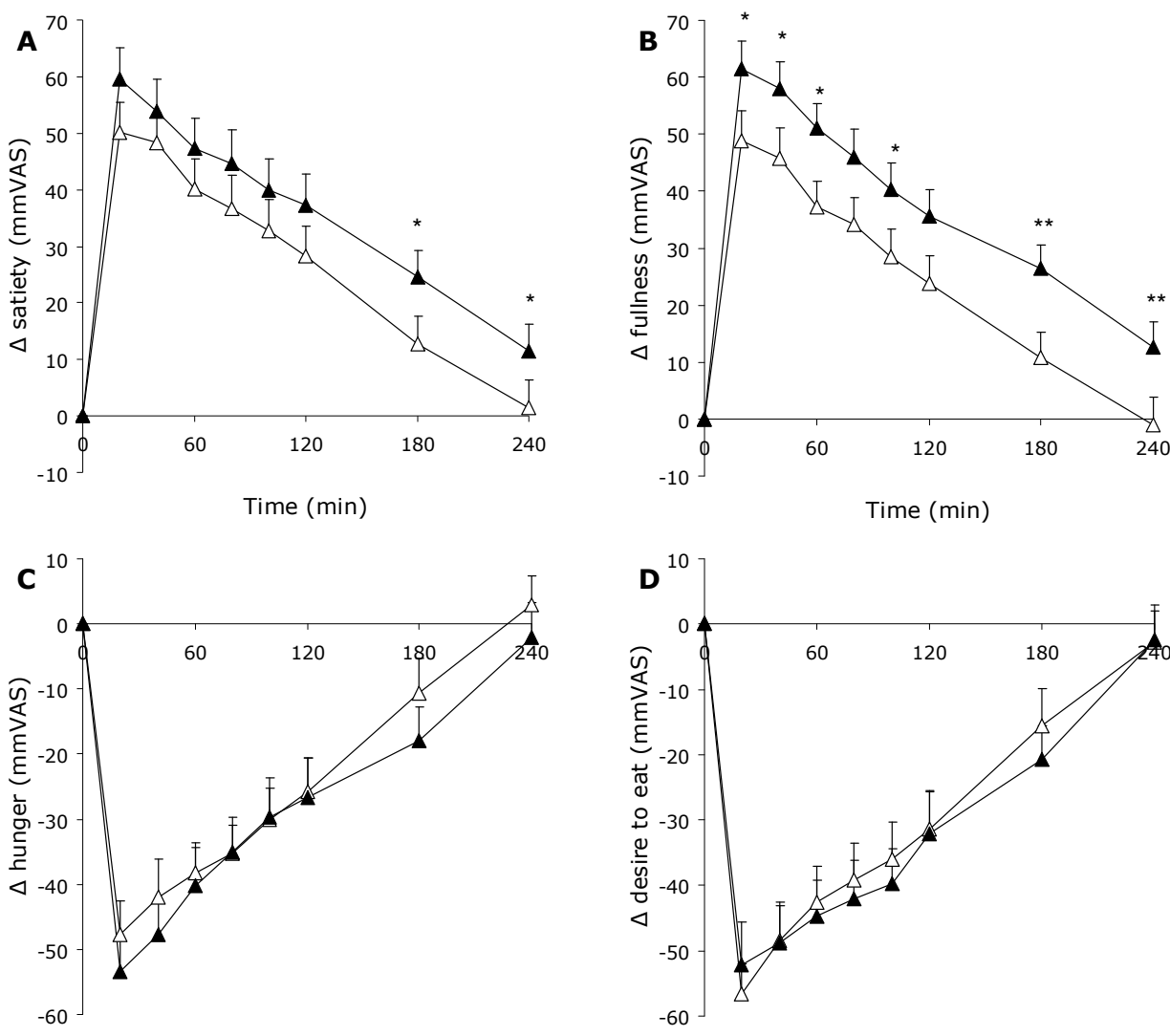

Time $(\min )$

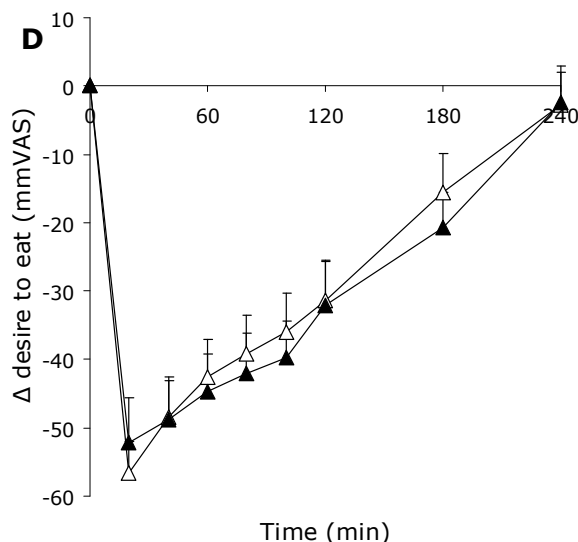

Figure 1 Changes in satiety (A), fullness (B), hunger (C) and desire to eat (D) (all in mm visual analogue scale; VAS) after a casein-breakfast given as a custard with either $10 \%$ of energy from casein-protein $(\triangle)$ or $25 \%$ of energy from casein-protein (A) expressed as change compared with baseline in twenty-five subjects (men and women). Values are means $+\mathrm{SEM} .{ }^{*} \mathrm{P}$ $<0.05, * * \mathrm{P}<0.01$ (repeated-measures ANOVA)

\section{Taste perception}

Ratings of taste perception profiles and of pleasantness of taste of the custards were not different between the breakfast with $25 \%$ of energy from casein and the breakfast with $10 \%$ of energy from protein (table $\mathbf{3}$ ).

\section{Glucose}

Baseline plasma glucose concentrations were not different among treatments (table 2). The glucose response expressed as AUC was increased after the breakfast with $10 \%$ of energy from casein $(123.70 \pm 14.25 \mathrm{mmol} / \mathrm{l} . \mathrm{h})$ compared with the breakfast with $25 \%$ of energy from casein $(68.04 \pm 18.11 \mathrm{mmol} / \mathrm{l} . \mathrm{h}, P<0.05)$. Glucose concentration was increased after the breakfast with $10 \%$ of energy from casein compared with the breakfast with $25 \%$ of energy from casein at 40 and 60 minutes after breakfast $(P<0.05$ and $P<0.05$, figure 2$)$. 
Table 3 Taste perception profiles and hedonic values on $100 \mathrm{~mm}$ visual analogue scales of the breakfasts given as a custard with either $10 \%$ of energy or $25 \%$ of energy from casein-protein assed in twenty-five subjects (men and women)* (Mean values with their standard errors)

\begin{tabular}{lrr}
\hline & $\begin{array}{c}\text { casein } 10 \% \\
\text { of energy }\end{array}$ & $\begin{array}{c}\text { casein } 25 \% \\
\text { of energy }\end{array}$ \\
Pleasantness of taste & $58 \pm 4$ & $50 \pm 3$ \\
Sweetness & $54 \pm 6$ & $52 \pm 5$ \\
Saltiness & $9 \pm 3$ & $11 \pm 3$ \\
Bitterness & $16 \pm 4$ & $14 \pm 4$ \\
Sourness & $16 \pm 4$ & $11 \pm 3$ \\
Creaminess & $56 \pm 6$ & $53 \pm 5$ \\
Crispiness & $2 \pm 1$ & $3 \pm 1$ \\
Savouriness & $15 \pm 4$ & $19 \pm 4$ \\
& & \\
\hline
\end{tabular}

*Repeated-measures ANOVA repeated measures; no significant differences

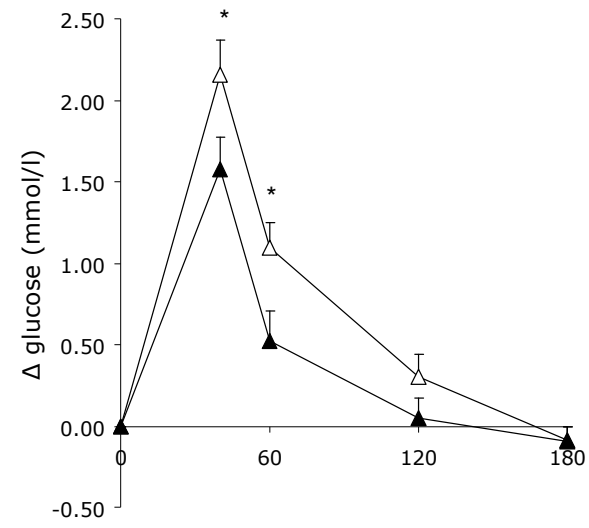

Time $(\min )$

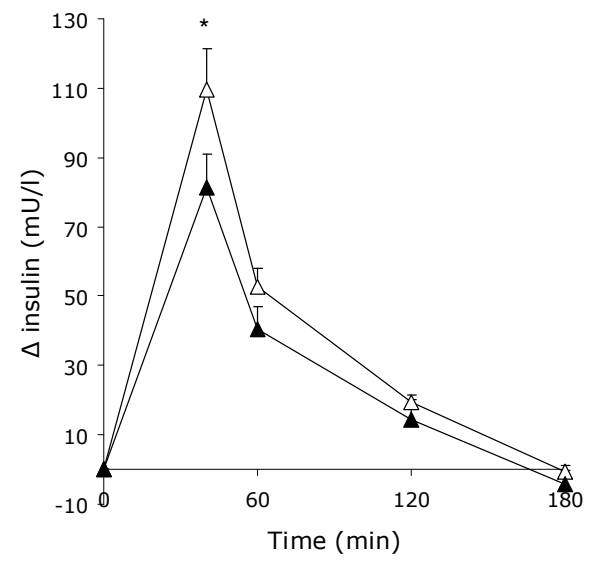

Figure 3 Changes in insulin concentrations $(\mathrm{mU} / \mathrm{l})$ after a casein-breakfast given as a custard with either $10 \%$ of energy from casein-protein $(\triangle)$ or $25 \%$ of energy from casein-protein $(\boldsymbol{\Delta})$ expressed as change compared with baseline in twenty-five subjects (men and women). Values are means + SEM. ${ }^{*} \mathrm{P}<0.05$ (repeated-measures ANOVA) 


\section{Insulin}

Baseline plasma insulin concentrations were not different among treatments (table 2). Insulin concentration was increased after the breakfast with $10 \%$ of energy from casein compared with the breakfast with $25 \%$ of energy from casein at 40 minutes after breakfast $(P<0.05$, figure 3 ).

\section{GLP-1 and ghrelin}

Baseline plasma GLP-1 and ghrelin concentrations were not different among treatments (table 2). There were no significant differences in GLP-1 or ghrelin concentrations between a high and a normal casein breakfast (data not shown).

\section{Amino acids and urea}

Baseline plasma amino acid and urea concentrations were not different among treatments (table 4). The AUC of the response of glutamate, asparagine, serine, glutamine, histidine, glycine, threonine, citrulline, arginine, alanine, taurine, alpha-aminobutyric acid, tyrosine, valine, methionine, isoleucine, phenylalanine, tryptophan, leucine, ornithine, lysine, branched-chain amino acids (BCAA), total amino acids (sum $A A$ ), and urea are presented in table 4; significant differences between treatments are indicated.

Compared with the breakfast with $10 \%$ of energy from casein, almost all amino acids showed a prolonged elevation with a typically pattern after the breakfast with $25 \%$ of energy from casein. Plasma amino acid concentrations rose immediately after breakfast to peak values at 40 minutes after breakfast. Then concentrations slightly decreased, with concentrations increasing again from 80 minutes onwards. The second peak levels were reached at 180 minutes after breakfast. To illustrate this phenomenon figure $\mathbf{4}$ presents the plasma amino acid concentrations over time of the BCAA and sum AA. The prolonged elevated concentrations were shown with nearly all amino acids; sum AA and BCAA, as well as glutamate, asparagine, serine, glutamine, histidine, threonine, arginine, alanine, alpha-aminobutyric acid, tyrosine, valine, methionine, isoleucine, phenylalanine, tryptophan, leucine, ornithine, and lysine concentrations were increased at 180 and 240 minutes after the breakfast with $25 \%$ of energy from casein compared with the breakfast with $10 \%$ of energy from casein $(P<0.05)$.

The urea response expressed as AUC was increased after the breakfast with $25 \%$ of energy from casein compared with a breakfast with $10 \%$ of energy from casein $(P<0.001$, table 4$)$.

\section{Energy intake}

Based on the results of appetite profile ratings and the concentrations of amino acids the ad lib lunch was offered at 180 minutes after breakfast.

Energy intake at lunch was $3133 \pm 226 \mathrm{~kJ}$ and $3080 \pm 229 \mathrm{~kJ}$ after the breakfast with $10 \%$ and $25 \%$ of energy from protein, respectively (ns). 
Table 4 Baseline values and areas under the curve (AUC) of amino acid ( $\mu \mathrm{mol} / \mathrm{l}$ and $\mu \mathrm{mol} / \mathrm{l} . \mathrm{h}$ ) and urea $(\mathrm{mmol} / \mathrm{l}$ and $\mathrm{mmol} / \mathrm{l} . \mathrm{h}$ ) responses after a casein-protein breakfast given as a custard with either $10 \%$ of energy or $25 \%$ of energy from casein-protein in twenty-five subjects (men and women) ${ }^{\dagger}$ (Mean values with their standard errors)

casein $10 \%$ of energy

Baseline

$104 \pm 4$

$58 \pm 2$

Glutamate

Asparagine

Serine

Glutamine

Histidine

Glycine

Threonine

Citrulline

Arginine

Alanine

Taurine

Alpha-aminobutyric acid

Tyrosine

Valine

Methionine

Isoleucine

Phenylalanine

Tryptophan

Leucine

Ornithine

Lysine

Branched-chain amino acid:

Sum amino acids

Urea
$127 \pm 4$

$522 \pm 13$

$94 \pm 3$

$239 \pm 11$

$143 \pm 5$

$31 \pm 1$

$88 \pm 3$

$316 \pm 18$

$34 \pm 1$

$18 \pm 1$

$57 \pm 3$

$192 \pm 6$

$25 \pm 1$

$64 \pm 2$

$49 \pm 1$

$49 \pm 1$

$110 \pm 3$

$53 \pm 2$

$154 \pm 5$

$368 \pm 9$

$2534 \pm 50$

$4.10 \pm 0.19$
AUC

$\begin{aligned}-102 & \pm 506 \\ 2717 & \pm 263 \\ 3574 & \pm 500 \\ 1072 & \pm 1489 \\ 2069 & \pm 217 \\ -2242 & \pm 438 \\ 4414 & \pm 333 \\ -938 & \pm 134 \\ 1845 & \pm 238 \\ 30021 & \pm 2219 \\ -464 & \pm 117 \\ 149 & \pm 84 \\ 3676 & \pm 473 \\ 7877 & \pm 409 \\ 1799 & \pm 212 \\ 4624 & \pm 292 \\ 1990 & \pm 154 \\ -216 & \pm 144 \\ 7027 & \pm 393 \\ 2366 & \pm 284 \\ 13181 & \pm 725 \\ 19528 & \pm 959 \\ 84438 & \pm 5316 \\ -48 & \pm 14\end{aligned}$

casein $25 \%$ of energy

$\begin{aligned} & \text { Baseline } \\ & 98 \pm 4 \\ & 56 \pm 1 \\ & 128 \pm 5 \\ & 518 \pm 15 \\ & 95 \pm 3 \\ & 224 \pm 11 \\ & 138 \pm 6 \\ & 31 \pm 1 \\ & 86 \pm 3 \\ & 288 \pm 13 \\ & 33 \pm 1 \\ & 19 \pm 1 \\ & 56 \pm 2 \\ & 191 \pm 6 \\ & 24 \pm 1 \\ & 67 \pm 2 \\ & 50 \pm 1 \\ & 49 \pm 1 \\ & 117 \pm 4 \\ & 54 \pm 3 \\ & 170 \pm 5 \\ & 375 \pm 11 \\ & 2493 \pm 51 \\ & 4.12 \pm 0.16\end{aligned}$

${ }^{*} P<0.05,{ }^{*} * P<0.01, * * * P<0.001$

† Repeated-measures ANOVA
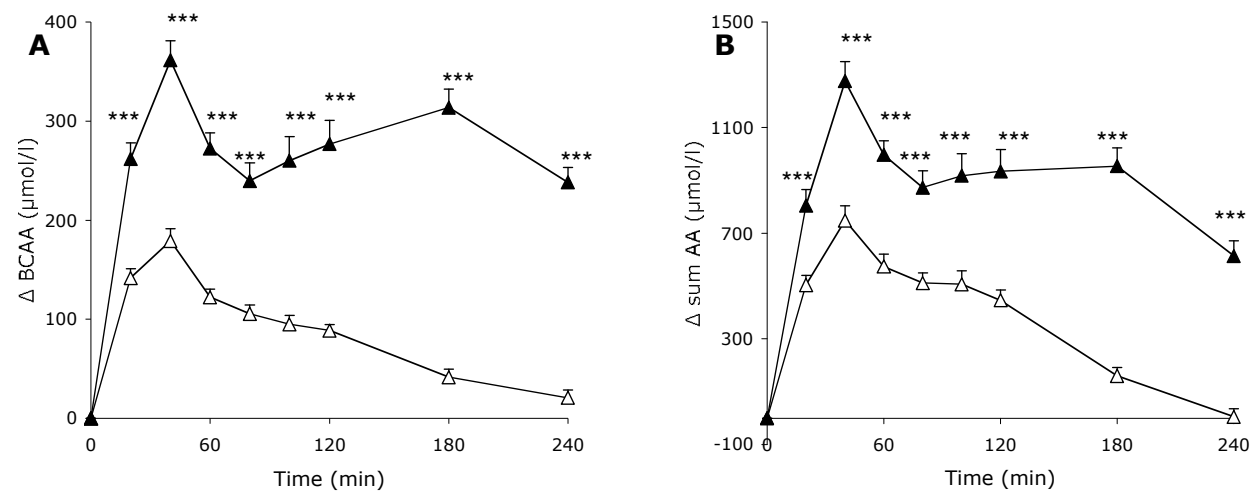

Figure 4 Changes in plasma branched-chain amino acid (BCAA) concentrations $(\mu \mathrm{mol} / \mathrm{I})(\mathrm{A})$ and plasma total amino acids (sum AA) concentrations $(\mu \mathrm{mol} / \mathrm{l})$ (B) after a casein-breakfast given as a custard with either $10 \%$ of energy from casein-protein $(\triangle)$ or $25 \%$ of energy from casein-protein ( $\boldsymbol{\Delta})$ expressed as change compared with baseline in twenty-five subjects (men and women). Values are means + SEM. ${ }^{* * *} P<0.001$ (repeated-measures ANOVA) 


\section{DISCUSSION}

Ratings of satiety and fullness were higher after a subject-specific breakfast consisting of $20 \%$ of total daily energy requirements with casein at a concentration of $25 \%$ of energy from protein compared with the breakfast with $10 \%$ of energy from casein, particularly at three and four hours after breakfast. Energy intake at lunch was not different after a high or normal casein breakfast. Sometimes it is suggested that protein-induced satiety is partly due to specific sensory effects (8). There is however hardly any evidence for this suggestion, especially not in the case of amounts of protein of $\sim 30 \mathrm{~g}$ in combination with carbohydrate and fat in a meal. Clearly, most amino acids evoke taste aversive responses because they have a bitter or sour taste (31). This is why we did not use pure amino acids yet applied complete proteins. Nevertheless, to avoid any specific sensory effect, food technology was involved to optimize taste and hedonic value of the breakfasts. The custards were vanilla-lemon flavoured and after being tested by a professional taste panel of NIZO Food Research taste perception and hedonic values again were evaluated by the subjects (see table 2 ) and were excluded to affect appetite profile ratings differently.

The increased satiety after the breakfast with $25 \%$ of energy from casein compared with the breakfast with $10 \%$ of energy from casein coincided with prolonged elevated concentrations of amino acids. Since postprandial amino acid profiles are likely to reflect rates of digestion, absorption, and metabolism, the prolonged elevated concentrations indicate a difference in protein kinetics between the two breakfasts. Previously it has been shown that casein coagulates in the stomach which delays gastric emptying; therefore casein is considered as a 'slow' protein. The higher the casein concentration the slower the release of food into the duodenum $(18,19,32)$. This is reflected by the typical pattern of amino acid concentrations over time. The largest differences in amino acid concentrations between the breakfasts with $25 \%$ and $10 \%$ of energy from casein existed at three and four hours after breakfast. These prolonged elevated concentrations may have contributed to the increased satiety ratings after the breakfast with $25 \%$ of energy from casein, which is in line with Mellinkoff's amino static theory that states that a larger rise in plasma amino acids increases satiety (20). The increased satiety ratings after the breakfast with $25 \%$ of energy from casein may thus be explained by increased concentrations of amino acids caused by the delayed gastric emptying of casein.

Surprisingly, the insulin concentration was increased after the breakfast with $10 \%$ of energy from casein whereas the glucose response expressed as AUC also was significantly increased after the breakfast with $10 \%$ of energy from casein compared with the breakfast with $25 \%$ of energy from casein whereas the carbohydrate content of the two breakfasts was exactly the same. The slower release of food into the duodenum after the high casein breakfast also delayed and diminished the rise of glucose and subsequently insulin concentrations in the circulation. Previously, insulin concentrations have been shown not to increase after consumption of a meal with 'slow' proteins in healthy young adults (19). Protein kinetics, reflected by changes in plasma amino acid concentrations, were different between the high and normal casein breakfast. The high casein breakfast revealed a plasma amino acid pattern that is typically for a 'slow' protein and that was, besides glucose and insulin responses, also reflected by the changes in GLP-1 and ghrelin concentration. The absence of significant differences in GLP1 or ghrelin concentrations between the high and normal casein breakfast may be the result of the delayed gastric emptying and thus retarded entrance of food in the intestine followed by a 
diminished physiological response of GLP-1 secretion and a less pronounced decrease in ghrelin concentration. In summary, the breakfast with $25 \%$ of energy from casein delayed gastric emptying more compared with the breakfast with $10 \%$ of energy from casein resulting in less pronounced changes in insulin, GLP-1, and ghrelin.

In literature differences in 'satiety' hormone responses between the different macronutrients have been shown $(12,13,33,34)$. In a review by Cummings it is stated that protein intake does not affect ghrelin response particularly (35). For instance no differences in ghrelin concentrations after a high protein ( $30 \mathrm{En} \%$ protein) compared with a normal protein diet (10 En\% protein) were observed, when the high or normal protein diet was given during three meals over a day (36). Foster-Schubert however reported a stronger suppression of ghrelin by proteins compared with fat or carbohydrates (33), with a test meal extremely high in protein with hardly any of the other macronutrients present. This makes comparisons with less extreme meals, such as in the present study a moderately high protein meal that is representative for a relatively high daily protein intake of $25 \%$ of energy from protein with a normal amount of carbohydrates ( 55 En\%) and a low amount of fat (20 En\%), difficult. Other observations showed that different types of protein modified 'satiety' hormone responses differently in some $(11,15)$ but not all studies $(14,16)$. In the present study there were no differences in GLP-1 and ghrelin between two levels of casein-protein, probably due to the fact that casein is a 'slow' protein. This would result in a compensation of the effect of concentration by pace of nutrient stimulated hormone release.

Despite significantly increased ratings of satiety after the breakfast with $25 \%$ of energy from casein at three hours after breakfast, energy intake was similar after the high and normal casein breakfast. Apparently the difference in satiety ratings of 12-15 mmVAS was not large enough to induce a significant effect on food intake. Previously, Diepvens et al. also reported a significant suppressive effect of a preload on appetite ratings whereas there was no effect on ad lib energy intake four hours after the preload. They concluded that the difference in hunger scores may be too small to exert an effect on subsequent energy intake and that timing is of major importance to observe significant effects on food intake (37). In the past there have been experiments that showed differences in subsequent energy intake between types of protein offered as a preload without significant differences in appetite ratings $(11,38,39)$. In case subsequent energy intake is affected without pre-prandial indications of appetite profile ratings, it may well be that the combination of the digested food from the previous preload or meal with the new digested food in the gut may evoke uncomfortable feelings that stop further energy intake. Furthermore, differences in timing may explain different results; timing is essential in studying ad lib energy intake after a preload or a meal as shown by Anderson et al. (38). In accordance with other studies (37), the present study shows that differences in appetite ratings thus need to be at least larger than 15 mmVAS in order to have a significant effect on subsequent energy intake. Although the high casein breakfast was rated as more satiating than the normal casein breakfast the difference was not large enough to induce a reduction in energy intake.

Urea concentrations were elevated more after the high casein breakfast compared with the normal protein breakfast with casein. The high urea concentrations reflect an excess of amino acids and a state of positive protein balance after the high protein breakfasts. Postprandial protein synthesis has high ATP costs $(40)$ and when amino acids are given in excess of protein deposition, amino acid oxidation plays a major role in energy expenditure and protein oxidation 
$(41,42)$, that previously has been shown to be related to diet-induced thermogenesis and increased satiety $(9,43)$.

This is the first study that investigated acute differences in satiety between two concentrations of casein; previously the satiating properties of casein only have been compared with other protein types $(11,14)$. This study shows that a breakfast with $25 \%$ of energy from casein is rated as being more satiating than a breakfast with $10 \%$ of energy from casein at three and four hours after breakfast coinciding with prolonged elevated concentrations of plasma amino acids but does not reduce subsequent energy intake.

\section{ACKNOWLEDGEMENTS}

MABV, AGN, AH-W, KRW, MPKJE, RJMB, NEPD, and MSW-P designed the study. MABV and AH$W$ collected and analyzed the data. MABV wrote the manuscript and AGN, KRW, MPKJE, NEPD, and MSW-P contributed to interpretation of the data and reviewed the manuscript. The study was executed under supervision of AGN, KRW, and MSW-P. None of the authors had a personal or financial conflict of interest.

\section{REFERENCES}

1. Seidell JC. Obesity in Europe. Obes Res 1995;3 Suppl 2:89s-93s.

2. Pi-Sunyer FX. Medical hazards of obesity. Ann Intern Med 1993;119:655-60.

3. Westerterp-Plantenga MS, Luscombe-Marsh N, Lejeune MP, et al. Dietary protein, metabolism, and bodyweight regulation: dose-response effects. Int J Obes (Lond) 2006;30 Suppl 3:S16-23.

4. Skov AR, Toubro S, Ronn B, Holm L, Astrup A. Randomized trial on protein vs carbohydrate in ad libitum fat reduced diet for the treatment of obesity. Int J Obes Relat Metab Disord 1999;23:528-36.

5. Lejeune MP, Kovacs EM, Westerterp-Plantenga MS. Additional protein intake limits weight regain after weight loss in humans. Br J Nutr 2005;93:281-9.

6. Weigle DS, Breen PA, Matthys CC, et al. A high-protein diet induces sustained reductions in appetite, ad libitum caloric intake, and body weight despite compensatory changes in diurnal plasma leptin and ghrelin concentrations. Am J Clin Nutr 2005;82:41-8.

7. Clifton PM, Keogh JB, Noakes M. Long-term effects of a high-protein weight-loss diet. Am J Clin Nutr 2008;87:23-9.

8. Bertenshaw EJ, Lluch A, Yeomans MR. Satiating effects of protein but not carbohydrate consumed in a between-meal beverage context. Physiol Behav 2008;93:427-36.

9. Crovetti R, Porrini M, Santangelo A, Testolin G. The influence of thermic effect of food on satiety. Eur J Clin Nutr 1998;52:482-8.

10. Halton TL, Hu FB. The effects of high protein diets on thermogenesis, satiety and weight loss: a critical review. J Am Coll Nutr 2004;23:373-85.

11. Hall WL, Millward DJ, Long SJ, Morgan LM. Casein and whey exert different effects on plasma amino acid profiles, gastrointestinal hormone secretion and appetite. Br J Nutr 2003;89:239-48.

12. Bowen J, Noakes M, Clifton PM. Appetite regulatory hormone responses to various dietary proteins differ by body mass index status despite similar reductions in ad libitum energy intake. J Clin Endocrinol Metab 2006;91:2913-9.

13. Bowen J, Noakes M, Trenerry C, Clifton PM. Energy intake, ghrelin, and cholecystokinin after different carbohydrate and protein preloads in overweight men. J Clin Endocrinol Metab 2006;91:1477-83.

14. Lang V, Bellisle F, Oppert JM, et al. Satiating effect of proteins in healthy subjects: a comparison of egg albumin, casein, gelatin, soy protein, pea protein, and wheat gluten. Am J Clin Nutr 1998;67:1197-204.

15. Lang V, Bellisle F, Alamowitch C, et al. Varying the protein source in mixed meal modifies glucose, insulin and glucagon kinetics in healthy men, has weak effects on subjective satiety and fails to affect food intake. Eur J Clin Nutr 1999;53:959-65. 
16.

17.

18.

40.

41.

42.

43.

Uhe AM, Collier GR, O'Dea K. A comparison of the effects of beef, chicken and fish protein on satiety and amino acid profiles in lean male subjects. J Nutr 1992;122:467-72.

Miller MJ, Witherly SA, Clark DA. Casein: a milk protein with diverse biologic consequences. Proc Soc Exp Biol Med 1990;195:143-59.

Boirie Y, Dangin M, Gachon P, Vasson MP, Maubois JL, Beaufrere B. Slow and fast dietary proteins differently modulate postprandial protein accretion. Proc Natl Acad Sci U S A 1997;94:14930-5.

Dangin M, Boirie Y, Garcia-Rodenas C, et al. The digestion rate of protein is an independent regulating factor of postprandial protein retention. Am J Physiol Endocrinol Metab 2001;280:E340-8.

Mellinkoff SM, Frankland M, Boyle D, Greipel M. Relationship between serum amino acid concentration and fluctuations in appetite. J Appl Physiol 1956;8:535-8.

Spaaij CJ, Pijls LT. New dietary reference intakes in the Netherlands for energy, proteins, fats and digestible carbohydrates. Eur J Clin Nutr 2004;58:191-4.

Munro HN. Second Boyd Orr Memorial Lecture. Regulation of body protein metabolism in relation to diet. Proc Nutr Soc 1976;35:297-308.

Stunkard AJ, Messick S. The three-factor eating questionnaire to measure dietary restraint, disinhibition and hunger. J Psychosom Res 1985;29:71-83.

Westerterp-Plantenga MS, Westerterp KR, Rubbens M, Verwegen CR, Richelet JP, Gardette B. Appetite at "high altitude" [Operation Everest III (Comex-'97)]: a simulated ascent of Mount Everest. J Appl Physiol 1999;87:3919.

Adam TC, Westerterp-Plantenga MS. Nutrient-stimulated GLP-1 release in normal-weight men and women. Horm Metab Res 2005;37:111-7.

Stubbs RJ, Hughes DA, Johnstone AM, et al. The use of visual analogue scales to assess motivation to eat in human subjects: a review of their reliability and validity with an evaluation of new hand-held computerized systems for temporal tracking of appetite ratings. Br J Nutr 2000;84:405-15.

Flint A, Raben A, Blundell JE, Astrup A. Reproducibility, power and validity of visual analogue scales in assessment of appetite sensations in single test meal studies. Int J Obes Relat Metab Disord 2000;24:38-48. van Eijk HM, Rooyakkers DR, Deutz NE. Rapid routine determination of amino acids in plasma by highperformance liquid chromatography with a 2-3 microns Spherisorb ODS II column. J Chromatogr 1993;620:1438.

Senn S. Cross-over trials in Statistics in Medicine: The first '25' years. Statistics in Medicine 2006;25:3430-3442.

Kirimura J, Shimizi A, Kimizuka A, Ninomiya T, Katsuya N. The contribution of peptides and amino acids to the taste of foodstuffs. J Agric Food Chem 1969;17:689-695.

Mahe S, Roos N, Benamouzig R, et al. Gastrojejunal kinetics and the digestion of [15N]beta-lactoglobulin and casein in humans: the influence of the nature and quantity of the protein. Am J Clin Nutr 1996;63:546-52.

Foster-Schubert KE, Overduin J, Prudom CE, et al. Acyl and total ghrelin are suppressed strongly by ingested proteins, weakly by lipids, and biphasically by carbohydrates. J Clin Endocrinol Metab 2008;93:1971-9.

Erdmann J, Lippl F, Schusdziarra V. Differential effect of protein and fat on plasma ghrelin levels in man. Regul Pept 2003;116:101-7.

Cummings DE. Ghrelin and the short- and long-term regulation of appetite and body weight. Physiol Behav 2006;89:71-84.

Lejeune MP, Westerterp KR, Adam TC, Luscombe-Marsh ND, Westerterp-Plantenga MS. Ghrelin and glucagonlike peptide 1 concentrations, 24-h satiety, and energy and substrate metabolism during a high-protein diet and measured in a respiration chamber. Am J Clin Nutr 2006;83:89-94.

Diepvens K, Steijns J, Zuurendonk P, Westerterp-Plantenga MS. Short-term effects of a novel fat emulsion on appetite and food intake. Physiol Behav 2008;95:114-7.

Anderson GH, Tecimer SN, Shah D, Zafar TA. Protein source, quantity, and time of consumption determine the effect of proteins on short-term food intake in young men. J Nutr 2004;134:3011-5.

Borzoei S, Neovius M, Barkeling B, Teixeira-Pinto A, Rossner S. A comparison of effects of fish and beef protein on satiety in normal weight men. Eur J Clin Nutr 2006;60:897-902.

van Milgen J. Modeling biochemical aspects of energy metabolism in mammals. J Nutr 2002;132:3195-202.

Pannemans DL, Wagenmakers AJ, Westerterp KR, Schaafsma G, Halliday D. Effect of protein source and quantity on protein metabolism in elderly women. Am J Clin Nutr 1998;68:1228-35.

Robinson SM, Jaccard C, Persaud C, Jackson AA, Jequier E, Schutz Y. Protein turnover and thermogenesis in response to high-protein and high-carbohydrate feeding in men. Am J Clin Nutr 1990;52:72-80.

Westerterp-Plantenga MS, Rolland V, Wilson SA, Westerterp KR. Satiety related to $24 \mathrm{~h}$ diet-induced thermogenesis during high protein/carbohydrate vs high fat diets measured in a respiration chamber. Eur J Clin Nutr 1999;53:495-502. 

Chapter 4

Effects of high and normal soyprotein breakfasts on satiety and subsequent energy intake, including amino acid and 'satiety' hormone responses

Veldhorst MAB, Nieuwenhuizen AG, Hochstenbach-Waelen A, Westerterp KR, Engelen MPKJ, Brummer RJM, Deutz NEP, Westerterp-Plantenga MS

Eur J Nutr 2009; 48 (2): 92-100 


\section{ABSTRACT}

Background: The role of dietary protein in short term satiety is of interest with respect to body weight regulation.

Aim: To compare the effects of a high versus a normal soyprotein breakfast on satiety and subsequent energy intake, including 'satiety' hormones and plasma amino acid responses.

Methods: Twenty-five healthy subjects (mean \pm SEM BMI: $23.9 \pm 0.3 \mathrm{~kg} / \mathrm{m}^{2}$; age: $22 \pm 1$ years) received a subject-specific standardized breakfast: a custard with soy as single protein type with either 10/55/35 (normal-protein) or 25/55/20 (high-protein) En\% protein/carbohydrate/fat in a randomized, single-blind design. Appetite profile (Visual Analogue Scale, VAS), plasma glucose, insulin, Glucagon-like Peptide 1 (GLP-1), ghrelin, and amino acid (AA) concentrations were determined for four hours, determining the sensitive time point to assess energy intake (EI). Since at 180 minutes glucose and insulin concentrations still were significantly different, in a second set of experiments subjects received an ad lib lunch at 180 minutes after the breakfasts; El was assessed.

Results: Overall the $25 \mathrm{En} \%$ soy-custard was rated as being more satiating than the $10 \mathrm{En} \%$ soycustard $(p<0.01)$ and there was a difference at 20 minutes after breakfast $(64 \pm 5$ mmVAS vs. 52 \pm 5 mmVAS, $p<0.05)$, related to higher postprandial taurine concentrations $(p<0.05)$. Insulin response was increased more after the $25 \mathrm{En} \%$ than after the $10 \mathrm{En} \%$ soy-custard (AUC: $7520 \pm$ $929 \mathrm{mU} / \mathrm{l} . \mathrm{h}$ vs. $4936 \pm 468 \mathrm{mU} / \mathrm{l} . \mathrm{h}, \mathrm{p}<0.001)$. There was no difference in $\mathrm{El}(25 \mathrm{En} \%: 3212 \pm 280$ kJ vs. $10 \mathrm{En} \%$ : $3098 \pm 286 \mathrm{~kJ}, \mathrm{~ns})$.

Conclusion: A high soyprotein breakfast is more satiating than a normal soyprotein breakfast related to elevated taurine and insulin concentrations.

KEYWORDS: $\quad$ satiety, energy intake, soyprotein, taurine, insulin 


\section{INTRODUCTION}

The increasing incidence of obesity is considered as a major health problem due to its comorbidity of a number of diseases, including diabetes mellitus type 2, cardiovascular disease, and certain types of cancer $(1,2)$. Obesity is the result of a positive energy balance due to energy intake exceeding energy expenditure. In the system of body weight regulation several pathways are involved and therefore weight management requires a multi-factorial approach (3). Recent findings suggest that a relatively elevated protein intake seems to play a role during weight loss as well as during weight maintenance thereafter (4-7). The importance of satiety in this respect appears from the study by Weigle et al. where a high protein diet reduced ad lib food intake while sustaining satiety at a comfortable level during a 12-week period (7). In addition to the protein-induced satiety after a high protein diet, protein-induced satiety has also been shown after a single meal (8-10). Previous studies have shown satiating effects of high versus normal protein meals with a mixture of habitually consumed proteins $(3,10)$. Data on specific proteins in different concentrations affecting satiety are however limited and the question remains whether the larger satiating effects of high protein meals hold for each specific type of protein. Soyprotein is considered as a complete protein. Its nutritional value is roughly equivalent to that of animal protein of high biological value (11). A number of studies in animals and humans suggest that consumption of soyprotein has beneficial effects on lipid metabolism and obesity. Several lines of evidence show that soyprotein may favorably affect lipid absorption, insulin resistance, fatty acid metabolism and other hormonal, cellular, or molecular changes associated with adiposity. Soyprotein has also been suggested to decrease energy intake through increased satiety (12).

In order to answer the question whether the larger satiating effect of high protein meals also holds for soyprotein, we investigated possible differences in satiety between a high and normal amount of soyprotein and the mechanisms accompanying those differences. Since the timing of a test meal plays an important role (13), first the sensitive moment in time to offer a test meal was determined. Soyprotein was offered as a single protein source in a breakfast consisting of $20 \%$ of the subject-specific daily energy requirements, with amounts of soyprotein that represent the highest recommended protein intake per day, i.e. $25 \%$ of energy from protein versus the lowest (normal) protein intake per day, $10 \%$ of energy from protein (14). Protein was exchanged with fat; carbohydrate content was kept constant at a level of $55 \mathrm{En} \%$ because of its effects on protein metabolism (15).

The aim of the study was to compare the effects of a high versus a normal amount of soyprotein containing breakfast on satiety and energy intake, including plasma amino acids, glucose, insulin, Glucagon-like Peptide 1 (GLP-1) and ghrelin concentrations over a four-hour period. After having determined the sensitive moment in time, subjects received in a second set of experiments the same breakfasts and ad lib energy intake at lunch was determined at this time point. 


\section{SUBJECTS AND METHODS}

\section{Subjects}

Thirty healthy male and female volunteers (Body Mass Index $22-30 \mathrm{~kg} / \mathrm{m}^{2}$, age $18-40$ years) were recruited by advertisements in local newspapers and on notice boards at the university. They underwent a screening including medical history, measurement of body weight and height and cognitive restrained eating using a Dutch translation of the Three Factor Eating Questionnaire (TFEQ) $(16,17)$. Twenty-five subjects (11 male, 14 female) were selected on being in good health, non-smokers, non-vegetarian, not cognitively dietary restraint (TFEQ Factor 1 score $\leq 9$ ), not using medication apart from oral contraceptives and at most moderate alcohol users $(\leq 10$ alcoholic consumptions per week). Their mean age was $22 \pm 1$ year, and their body weight was $74.4 \pm 1.8 \mathrm{~kg}$ (BMI: $23.9 \pm 0.3 \mathrm{~kg} / \mathrm{m}^{2}$ ). A written informed consent was obtained from these participants and the study protocol was approved by the Medical Ethical Committee of the Academic Hospital Maastricht.

\section{Study design}

A randomized, single blind, within-subject experimental study was performed. All subjects came to the university on two occasions, separated by at least one week. On each test day subjects received a subject-specific standardized breakfast and appetite ratings and blood parameters were obtained for four hours after breakfast.

The sensitive moment in time to offer lunch was determined by the latest time point after breakfast where (part of) the measured parameters still were statistically significant. After two months, when the sensitive moment in time was determined, subjects again came to the university on two occasions in a randomized, single blind design, separated by at least one week. On each test day subjects received a subject-specific standardized breakfast and an ad lib lunch was offered at the pre-determined time point.

\section{Breakfast}

Breakfast was offered as a custard with soy (Supro ${ }^{\circledR} 590$, The Solae Company, St. Louis, United States of America) as a single protein source, with either protein/carbohydrate/fat: 10/55/35 En\% (normal protein) or protein/carbohydrate/fat: 25/55/20 En\% (high protein). The breakfast contained $20 \%$ of daily energy requirements, calculated as basal metabolic rate (BMR), according to the equations of Harris-Benedict, multiplied by an activity index of 1.75 which is the average value reported for the general population in the Netherlands $(18,19)$. The mean energy content of the breakfast was $2.52 \pm 0.07 \mathrm{MJ}$ and the provided breakfasts were completely finished within 15 minutes.

The custards were produced by NIZO Food Research bv. (Ede, The Netherlands) and had tapioca starch (Farinex VA50T, AVEBE, Veendam, The Netherlands and Perfectamyl 3108 AVEBE, Veendam, The Netherlands) and sunflower oil (Reddy, NV Vandemoortele, Roosendaal, The Netherlands) as the carbohydrate and fat sources and were citrus-vanilla (Citrus, J.B. de lange, Belfeld, The Netherlands; Vanilla, J.B. de lange, Belfeld, The Netherlands) flavored. Extensive product development and use of a taste panel lead to custards that did not differ significantly in color, taste, or viscosity. The amino acid composition of the custards is presented in table 1. 
Table 1 Amino acid content of the breakfasts given as a custard with either $10 \mathrm{En} \%$ or 25 En\% soy-protein content (g amino acids/100 g custard)

\begin{tabular}{|c|c|c|}
\hline & soy & soy \\
\hline & $10 \%$ & $25 \%$ \\
\hline Glutamic acid $^{a}$ & 0.328 & 0.816 \\
\hline Aspartic acid ${ }^{b}$ & 0.200 & 0.497 \\
\hline Cysteine & 0.022 & 0.054 \\
\hline Histidine & 0.048 & 0.119 \\
\hline Glycine & 0.071 & 0.177 \\
\hline Threonine & 0.066 & 0.164 \\
\hline Arginine & 0.139 & 0.345 \\
\hline Alanine & 0.073 & 0.182 \\
\hline Isoleucine & 0.089 & 0.222 \\
\hline Phenylalanine & 0.094 & 0.234 \\
\hline Tryptophan & 0.023 & 0.057 \\
\hline Leucine & 0.145 & 0.360 \\
\hline Lysine & 0.110 & 0.274 \\
\hline Proline & 0.087 & 0.216 \\
\hline
\end{tabular}

${ }^{\text {a }}$ Glutamic acid = glutamine + glutamate

${ }^{\mathrm{b}}$ Aspartic acid = asparagine

Lunch

According to a normal Dutch lunch consisting of bread and a filling, lunch consisted of Turkish bread (400 g) with egg salad (400 g) with 13/41/46 En\% protein/carbohydrate/fat with an energy density of $11.4 \mathrm{~kJ} / \mathrm{g}$. Beforehand it was tested whether all subjects liked the lunch sufficiently. Subjects were instructed to eat till they were comfortably full.

\section{Study protocol}

The protocol started at $08.00 \mathrm{~h}$ after an overnight fast from $22.00 \mathrm{~h}$. A Venflon catheter was placed in a superficial dorsal vein of the hand for blood sampling. To obtain arterialized venous blood samples the hand was placed in a thermostatically controlled hot box at $60^{\circ} \mathrm{C}$ for 20 minutes before the sampling time. A basal blood sample was taken and appetite ratings were scored. After 5 minutes a second basal blood sample was obtained and breakfast was offered ( $\mathrm{t}=0$ minutes) and completed within 20 minutes. After the first and the last bite, taste perception was scored. Appetite ratings were completed just before breakfast and at $20,40,60,80,100$, 120,180 and 240 minutes after breakfast.

Blood samples for urea and amino acid determination were obtained at -5 minutes and subsequently at the same time points as the appetite ratings; blood samples for determination of glucose, insulin, and ghrelin concentrations were obtained before and 40,60, 120 and 180 minutes after breakfast. Venous blood samples for determination of GLP-1 concentration were obtained separately before, and at 30,60,90, 120 and 180 minutes after breakfast by means of 
a Venflon catheter placed in an antecubital vein (20). Subjects were allowed to drink two glasses of water spread over the morning.

In the second set of experiments, the protocol started after an overnight fast from $22.00 \mathrm{~h}$ at $8.30 \mathrm{~h}$ with scoring appetite ratings. Breakfast was offered ( $\mathrm{t}=0$ minutes) and completed within 20 minutes. Lunch was offered at the pre-determined time point of 180 minutes after breakfast (see Results section). Subjects were allowed to drink three glasses of water spread over the entire test period.

\section{Measurements}

\section{Appetite profile}

To determine the appetite profile, hunger, fullness, satiety, and desire to eat were rated on 100 $\mathrm{mm}$ Visual Analogue Scales (VAS), anchored with 'not at all' and 'extremely' during the test day (21). Subjects were instructed to rate themselves by marking the scale at the point that was most appropriate to their feeling at that time. The distance from this point to the left end of the scale was measured in $\mathrm{mm}$; changes from baseline $(\Delta)$ were calculated by subtracting the baseline score ( -5 minutes) from the score at a certain time point.

\section{Taste perception}

Taste perception profiles of the custards were assessed after the first and the last bite of the breakfast using $100 \mathrm{~mm}$ Visual Analogue Scales (VAS), anchored with 'not at all' and 'extremely' on the aspects: pleasantness, sweetness, sourness, saltiness, bitterness, savouriness, crispiness and creaminess.

\section{Energy intake}

Lunch was weighed before and after eating and energy intake was calculated by multiplying the difference of the weight of the lunch by the energy value of the lunch as determined by the product labels $(11.4 \mathrm{~kJ} / \mathrm{g})$.

\section{Blood parameters}

Blood was distributed into EDTA tubes for glucose, insulin, and ghrelin measurement. For GLP-1 measurement blood was collected in EDTA tubes with added dipeptidyl peptidase IV inhibitor. For amino acid and urea determination, blood was collected in lithium heparin tubes. Blood samples were centrifuged at $4^{\circ} \mathrm{C}$ for 10 minutes at $3000 \mathrm{rpm}$. Hydrochloric acid and phenylmethylsulfonyl fluoride were added to plasma for active ghrelin determination. For amino acid analysis, $250 \mu \mathrm{l}$ plasma was deproteinized by mixing it with $20 \mathrm{mg}$ dry sulfosalicylic acid. For analysis of urea, $200 \mu \mathrm{l}$ plasma was deproteinized by mixing it with $20 \mu \mathrm{l}$ of a $500 \mathrm{~g} / \mathrm{l}$ trichloroacetic acid solution. All samples were stored at $-80^{\circ} \mathrm{C}$ until further analysis. Plasma glucose concentrations were determined using the hexokinase method (Glucose HK 125 kit, ABX diagnostics, Montpellier, France). Insulin concentrations were measured by RIA (Linco Research Inc., St. Charles, Missouri, USA). Plasma active ghrelin concentrations were measured by ELISA (Linco Research Inc., St. Charles, Missouri, USA). Plasma active GLP-1 samples were analyzed using ELISA (EGLP-35K; Linco Research Inc., St. Charles, Missouri, USA). Plasma concentrations of 
amino acids were determined with the use of a fully automated HPLC (Pharmacia, Woerden, The Netherlands), after precolumn derivatization with o-phthaldialdehyde (22). Plasma urea was analyzed spectrophotometrically on a COBAS Mira S (Roche Diagnostica, Hoffman-La Roche, Basel, Switzerland).

\section{Statistical analysis}

Data are presented as mean changes from baseline \pm standard error to the mean (SEM), unless otherwise indicated (23). The area under the curve (AUC) of changes from baseline over time was calculated using the trapezoidal method. A repeated measures ANOVA was carried out to test for the effects of protein content and time and a protein content $x$ time interaction effect on changes in satiety ratings and concentrations of glucose, insulin, ghrelin, GLP-1 and taurine over time. Furthermore, differences between the breakfasts were analyzed per time point. A repeated measures ANOVA was carried out to test for the effect of protein content on the AUC of satiety ratings and concentrations of glucose, insulin, ghrelin, GLP-1, amino acids and urea.

Regression analyses were performed to determine the relationships between the AUC of appetite ratings and the AUC of plasma glucose, insulin, ghrelin, and amino acid responses. Furthermore, regression analyses between the AUC of plasma glucose, insulin, and ghrelin and the AUC of plasma amino acids were performed.

After the second set of experiments, a repeated measures ANOVA was carried out to determine possible differences in energy intake between the breakfasts. A p-value $<0.05$ was regarded as statistically significant. Statistical procedures were performed using StatView 5.0 (SAS Institute Inc., USA, 1998).

\section{RESULTS}

\section{Appetite profile}

Baseline satiety ratings were not different between treatments. There was no protein content $x$ time interaction effect (ns). Protein content $(p<0.01)$ and time $(p<0.001)$, however, both had an effect on satiety ratings (figure 1). Satiety ratings were more increased after a breakfast with $25 \%$ of energy from soyprotein than after a breakfast with $10 \%$ of energy from soyprotein $(p<0.01)$ and there were significant differences over time $(p<0.001$, figure 1$)$.

Analysis per time point revealed that after a breakfast with $25 \%$ of energy from soyprotein satiety ratings were more increased than after a breakfast with $10 \%$ of energy from soyprotein at 20 minutes ( $64 \pm 5$ mmVAS vs. $52 \pm 5$ mmVAS, $p<0.05$, figure 1 ).

\section{Taste perception}

Pleasantness of taste scores were $53 \pm 5$ mmVAS and $54 \pm 4$ mmVAS for the breakfast with $10 \%$ and $25 \%$ of energy from protein, respectively (ns).

\section{Glucose}

Baseline plasma glucose concentrations were not different between treatments. There was a protein content $x$ time interaction effect on glucose concentrations $(p<0.05)$, peak values were 
higher after a breakfast with $10 \%$ of energy from soyprotein whereas glucose concentrations stayed more increased at 120 and 180 minutes after a breakfast with $25 \%$ of energy from soyprotein (figure 2). Glucose concentrations were different over time ( $<<0.001$, figure 2).

Analysis per time point revealed that glucose concentration was more increased after a breakfast with $25 \%$ of energy from soy than after a breakfast with $10 \%$ of energy from soy at 180 minutes $(p<0.05$, figure 2$)$.

\section{Insulin}

Baseline plasma insulin concentrations were not different between treatments. The insulin response expressed as AUC was more increased after a breakfast with $25 \%$ of energy from soyprotein than after a breakfast with $10 \%$ of energy from soyprotein $(7520 \pm 929 \mathrm{mU} / \mathrm{l} . \mathrm{h}$ vs. $4936 \pm 468 \mathrm{mU} / \mathrm{l} . \mathrm{h}, \mathrm{p}<0.01$ ).

There was no protein content $x$ time interaction effect $(n s)$, whereas protein content $(p<0.001)$ and time $(p<0.001)$ both had an effect on insulin concentrations (figure 3 ). Insulin concentrations were more increased after a breakfast with $25 \%$ of energy from protein than after a breakfast with $10 \%$ of energy from protein $(p<0.001)$ and there were differences over time ( $p<0.001$, figure 3$)$.

Analysis per time point revealed that insulin concentrations were more increased after a breakfast with $25 \%$ of energy from soy than after a breakfast with $10 \%$ of energy from soy at 60 , 120 , and 180 minutes $(p<0.01, p<0.001$ and $p<0.01$ respectively, figure 3 ).

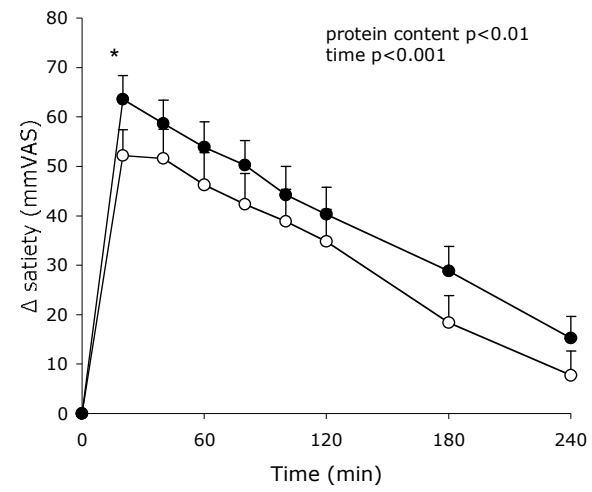

Figure 1 Changes in satiety (mmVAS) after a soy breakfast given as a custard with either $10 \mathrm{En} \%$ or $25 \mathrm{En} \%$ from protein expressed as delta compared to baseline in 25 subjects (men and women). Values are means + SEM. $\bigcirc$ $10 \%$ of energy from soyprotein, $25 \%$ of energy from soyprotein. ANOVA repeated measures showed an effect of protein content $(p<0.01)$ and time $(p<0.001)$ on satiety ratings; analysis per time point showed a difference in satiety at 20 minutes after breakfast ( $\left.{ }^{*} p<0.05\right)$.

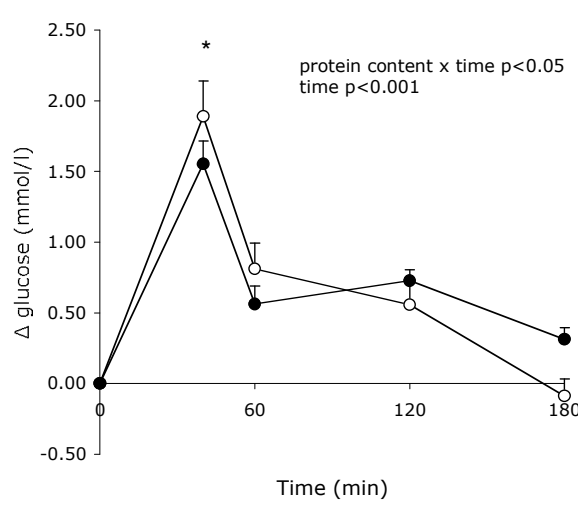

Figure 2 Changes in glucose concentrations ( $\mathrm{mmol} / \mathrm{l})$ after a soy breakfast given as a custard with either $10 \mathrm{En} \%$ or 25 En\% from protein expressed as delta compared to baseline in 25 subjects (men and women). Values are means + SEM. $10 \%$ of energy from soyprotein, $25 \%$ of energy from soyprotein. ANOVA repeated measures showed a protein content $x$ time interaction effect $(p<0.05)$ and an effect of time $(p<0.001)$ on glucose concentrations; analysis per time point showed a difference in glucose concentrations at 180 minutes (* $p<0.05)$. 


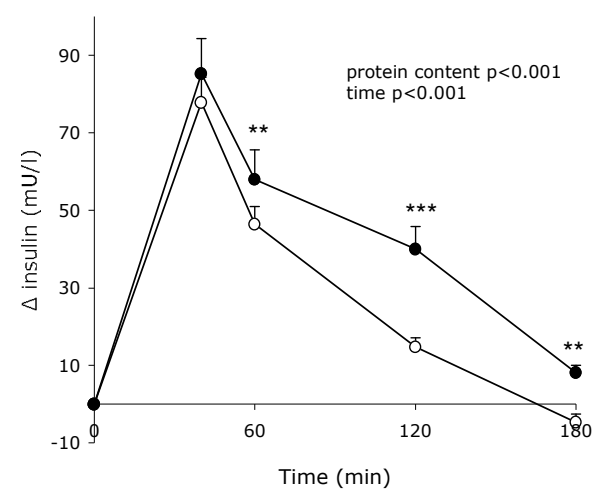

Figure 3 Changes in insulin concentrations $(\mathrm{mU} / \mathrm{I})$ after a soy breakfast given as a custard with either $10 \mathrm{En} \%$ or $25 \mathrm{En} \%$ from protein expressed as delta compared to baseline in 25 subjects (men and women). Values are means + SEM. $\bigcirc 10 \%$ of energy from soyprotein, $25 \%$ of energy from soyprotein. ANOVA repeated measures showed an effect of protein content $(p<0.001)$ and time $(p<0.001)$ on insulin concentrations; analysis per time point showed a difference in insulin concentrations at $60(* * p<0.01) 120(* * * p<0.001)$ and 180 minutes $(* * p<0.01)$.

\section{Ghrelin and GLP-1}

Baseline plasma ghrelin and GLP-1 concentrations were not different between treatments. There was no protein content $x$ time interaction effect or effect of protein content on ghrelin and GLP1 concentrations ( $n s)$, only time had an effect on ghrelin $(p<0.001)$ or GLP-1 concentration $(p<0.001)$. Analysis per time point revealed that there were no differences in ghrelin or GLP-1 concentrations between a breakfast with $25 \%$ of energy from soyprotein and a breakfast with $10 \%$ of energy from soyprotein (data not shown).

\section{Correlations}

The AUC of satiety and hunger scores after the breakfast with $25 \%$ of energy from soy were a function of the AUC of the amino acid taurine (satiety: $r=0.399, p<0.05$; hunger: $r=-0.433$, $p<0.05$, figure 4).

\section{Amino acids and urea}

Baseline plasma amino acid and urea concentrations were not different between treatments. The AUC of the response of glutamic acid, asparagine, serine, glutamine, histidine, glycine, threonine, citrulline, arginine, alanine, taurine, alpha-aminobutyric acid, tyrosine, valine, methionine, isoleucine, phenylalanine, tryptophan, leucine, ornithine, lysine, branched-chain amino acids (BCAA), sum amino acids (sum AA), and urea are presented in table 2; significant differences between treatments are indicated. The AUC of nearly all amino acids was more increased after the breakfast with $25 \%$ of energy from protein than after the breakfast with $10 \%$ of energy from $(p<0.05$, table 2$)$. 
The changes in taurine concentrations over time are shown in figure 5 . There was a protein content $x$ time interaction effect on taurine concentrations $(p<0.001)$ and an effect of time on taurine concentrations $(p<0.001$, figure 5$)$. Analysis per time point revealed that taurine concentrations were more increased at 40,60 , and 80 minutes after a breakfast with $25 \%$ of energy from soyprotein than after a breakfast with $10 \%$ of energy from soyprotein $(p<0.001$, $p<0.001$ and $p<0.01$ respectively, figure 5 ).

The AUC of the urea response was more increased after a breakfast with $25 \%$ of energy from protein than after a breakfast with $10 \%$ of energy from protein $(p<0.001$, table 2$)$.

A

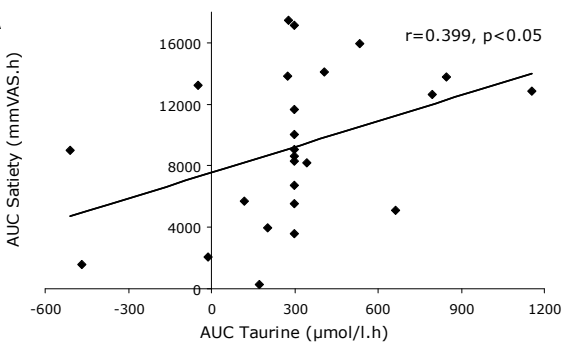

B

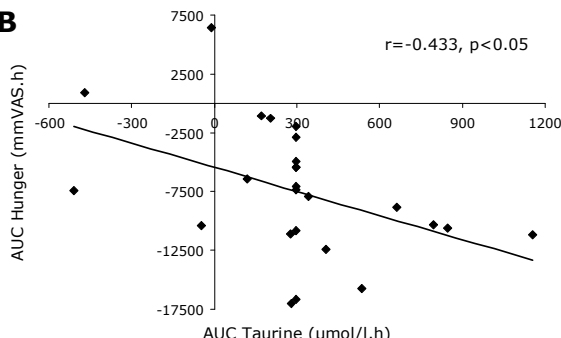

Figure 4 Relation between satiety responses (mmVAS/h) and taurine responses ( $\mu$ mol/l.h, A) and hunger responses (mmVAS/h) and taurine responses ( $\mu \mathrm{mol} / \mathrm{l} . \mathrm{h}, \mathrm{B}$ ) after a breakfast with $25 \%$ of energy from soyprotein in 25 subjects (men and women). The AUC of satiety was a function of the AUC of taurine $(r=0.399, p<0.05)$ and the $A U C$ of hunger was also a function of the AUC of taurine $(r=-0.433, p<0.05)$.

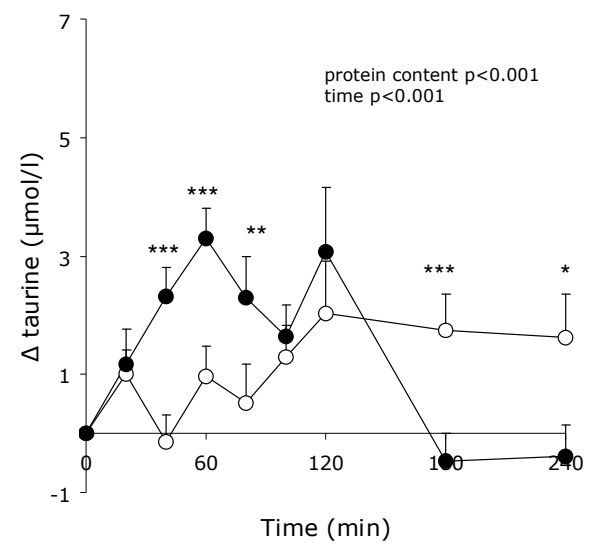

Figure 5 Changes in taurine concentrations ( $\mu \mathrm{mol} / \mathrm{l}$ ) after a soy breakfast given as a custard with either 10 En\% or 25 En\% from protein expressed as delta compared to baseline in 25 subjects (men and women). Values are means + SEM. $\bigcirc$ $10 \%$ of energy from soyprotein, $25 \%$ of energy from soyprotein. ANOVA repeated measures showed a protein content $x$ time interaction effect $(p<0.001)$ and an effect of time $(p<0.001)$ on taurine concentrations; analysis per time point showed a difference in taurine concentrations at 40

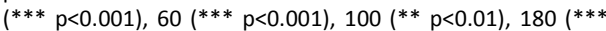
$\mathrm{p}<0.001)$ and 240 minutes $(* \mathrm{p}<0.05)$. 
Table 2 AUC of amino acid ( $\mu \mathrm{mol} / \mathrm{l} . \mathrm{h}$ ) and urea ( $\mathrm{mmol} / \mathrm{l} . \mathrm{h}$ ) responses after a soyprotein breakfast given as a custard with either $10 \mathrm{En} \%$ or $25 \% \mathrm{En} \%$ from protein in 25 subjects (men and women)

\begin{tabular}{|c|c|c|c|}
\hline & soy & soy & \\
\hline & $10 \%$ & $25 \%$ & \\
\hline Glutamate & $209 \pm 534$ & $3264 \pm 643$ & $* * *$ \\
\hline Asparagine & $5684 \pm 238$ & $13958 \pm 278$ & $* * *$ \\
\hline Serine & $3669 \pm 327$ & $10277 \pm 416$ & $* * *$ \\
\hline Glutamine & $1296 \pm 2881$ & $7818 \pm 943$ & $*$ \\
\hline Histidine & $2054 \pm 495$ & $4314 \pm 241$ & $* *$ \\
\hline Glycine & $2160 \pm 610$ & $6760 \pm 675$ & $* * *$ \\
\hline Threonine & $3975 \pm 553$ & $11500 \pm 544$ & $* * *$ \\
\hline Citrulline & $-894 \pm 152$ & $-273 \pm 136$ & $* *$ \\
\hline Arginine & $6248 \pm 517$ & $17924 \pm 669$ & $* * *$ \\
\hline Alanine & $32396 \pm 2585$ & $41833 \pm 2408$ & $* *$ \\
\hline Taurine & $307 \pm 120$ & $297 \pm 72$ & \\
\hline Alpha-aminobutyric acid & $122 \pm 78$ & $443 \pm 100$ & $*$ \\
\hline Tyrosine & $2439 \pm 322$ & $11091 \pm 509$ & $* * *$ \\
\hline Valine & $5696 \pm 786$ & $22855 \pm 870$ & $* * *$ \\
\hline Methionine & $-785 \pm 367$ & $954 \pm 233$ & $* *$ \\
\hline Isoleucine & $5143 \pm 326$ & $18154 \pm 450$ & $* * *$ \\
\hline Phenylalanine & $2984 \pm 236$ & $8098 \pm 285$ & $* * *$ \\
\hline Tryptophan & $253 \pm 254$ & $2571 \pm 197$ & $* * *$ \\
\hline Leucine & $4948 \pm 477$ & $21071 \pm 1393$ & $* * *$ \\
\hline Ornithine & $2978 \pm 196$ & $7918 \pm 411$ & $* * *$ \\
\hline Lysine & $8812 \pm 1068$ & $22530 \pm 922$ & $* * *$ \\
\hline Branched-chain amino acids & $15787 \pm 1492$ & $62081 \pm 2476$ & $* * *$ \\
\hline Sum amino acids & $89695 \pm 10998$ & $233355 \pm 8463$ & $* * *$ \\
\hline Urea & $-30 \pm 15$ & $118 \pm 15$ & $* * *$ \\
\hline
\end{tabular}

Values are means $\pm \mathrm{SEM}$, ANOVA repeated measures; ${ }^{*} \mathrm{p}<0.05,{ }^{* *} \mathrm{p}<0.01, * * * p<0.001$

\section{Energy intake}

The sensitive moment in time to determine El in the second set of experiments was based upon the differences in glucose and insulin responses, still being present at 180 minutes after breakfast, therefore this moment was chosen to offer lunch.

Energy intake at lunch was $3098 \pm 286 \mathrm{~kJ}$ and $3212 \pm 280 \mathrm{~kJ}$ after the breakfast with $10 \%$ and $25 \%$ of energy from protein, respectively (ns).

\section{DISCUSSION}

Satiety ratings were higher after a breakfast with $25 \%$ of energy from soyprotein compared with a breakfast with $10 \%$ of energy from soyprotein. The iso-energetic breakfasts contained $20 \%$ of the individual's total daily energy requirements and were of the same color, viscosity, and did not differ significantly in taste. 
There may be two different reasons for the observed difference in satiety. The increased satiety after the breakfast with $25 \%$ of energy from soyprotein coincided with an increased insulin response. Insulin is a metabolic satiety signal $(24,25)$ and may explain the increased perceived satiety.

The satiating properties of soyprotein also showed to be dependent on specific amino acid responses. A positive relationship was observed between satiety or hunger suppression and the concentration of the amino acid taurine. Due to the different pattern of taurine concentrations over time, the AUC of the taurine response was not significantly different between the two breakfasts. After a breakfast with $25 \%$ of energy from soyprotein, taurine concentrations increased more than after a breakfast with $10 \%$ of energy from soyprotein. However, after 120 minutes taurine concentrations decreased to levels below baseline after a breakfast with $25 \%$ of energy from soyprotein whereas taurine concentrations remained slightly elevated after a breakfast with $10 \%$ of energy from soyprotein. Therefore, there was no difference in taurine response expressed as AUC over four hours compared with the breakfast with $10 \%$ of energy from soyprotein. Nevertheless, in those subjects with an increased AUC of taurine an increased satiety and an increased hunger suppression was observed.

Plant proteins do not contain taurine (26), however, it can be synthesized from cysteine in the liver (27). Since soyprotein is rich in cysteine, this may have been the source of the elevated taurine concentrations (28). The liver readily synthesizes taurine when cysteine supply is adequate. It is formed via sequential actions of cysteine dioxygenase (CDO) which gives rise to cysteinesulfinate and cysteinesulfinate decarboxylase (CSD). Cysteinesulfinate is then decarboxylated by CSD to hypotaurine which is further oxidized to taurine (29). Healthy obese subjects were found to have lower taurine concentrations compared with non-obese age- and sex-matched healthy control subjects (30). Moreover, taurine ingestion has been shown to decrease body weight in hyperglycemic obese mice after a 5\% taurine diet for 10-14 weeks (31). Furthermore, intake of 3 gram taurine per day for 7 weeks reduced body weight significantly compared with placebo in a group of overweight and obese human subjects (32). In addition, taurine has also been shown to depress food intake in mice (33). The present study for the first time showed a direct relation between satiety and/or hunger suppression and taurine concentrations in humans. Sea foods are rich in taurine (26), the satiating effects of fish observed by Uhe et al. may be explained by the increased taurine concentrations (34). Thus, in addition to the literature the present study shows that an increased taurine concentration leads to increased feelings of satiety and suppressed hunger. To summarize, the increased satiety observed after the breakfast with $25 \%$ of energy from soyprotein may be caused by both increased insulin and taurine concentrations that were associated with satiety.

Despite the increased satiety after the breakfast with $25 \%$ of energy from soyprotein and the assessment of the sensitive moment in time, we observed no difference in ad lib energy intake at lunch between a breakfast with $25 \%$ of energy from soyprotein versus a breakfast with $10 \%$ of energy from soyprotein. Also no differences were present between a breakfast with $25 \%$ or $10 \%$ of energy from soyprotein with respect to the orexigenic and anorexigenic hormones ghrelin and GLP-1. Soyprotein thus does not contain the specific amino acids that trigger the secretion of these orexigenic and anorexigenic hormones considerably.

To summarize, a breakfast with $25 \%$ of energy from soyprotein was more satiating than a breakfast with $10 \%$ of energy from soyprotein, related to taurine concentrations. Insulin 
response after the breakfast with $25 \%$ of energy from soy was increased, whereas there were no differences in GLP-1 or ghrelin responses. In conclusion, a high soyprotein breakfast was being more satiating than a normal soyprotein breakfast related to elevated taurine and insulin concentrations.

\section{ACKNOWLEDGEMENTS}

MABV, AGN, AH-W, KRW, MPKJE, RJMB, NEPD, and MSW-P designed the study. MABV and AH$W$ collected and analyzed the data. MABV wrote the manuscript and AGN, KRW, MPKJE, NEPD, and MSW-P contributed to interpretation of the data and reviewed the manuscript. The study was executed under supervision of AGN, KRW, and MSW-P. None of the authors had a personal or financial conflict of interest.

\section{REFERENCES}

1. Pi-Sunyer FX. Medical hazards of obesity. Ann Intern Med 1993;119:655-60.

2. Seidell JC. Obesity in Europe. Obes Res 1995;3 Suppl 2:89s-93s.

3. Westerterp-Plantenga MS, Luscombe-Marsh N, Lejeune MP, et al. Dietary protein, metabolism, and bodyweight regulation: dose-response effects. Int J Obes (Lond) 2006;30 Suppl 3:S16-23.

4. Clifton PM, Keogh JB, Noakes M. Long-term effects of a high-protein weight-loss diet. Am J Clin Nutr 2008;87:23-9.

5. Lejeune MP, Kovacs EM, Westerterp-Plantenga MS. Additional protein intake limits weight regain after weight loss in humans. Br J Nutr 2005;93:281-9.

6. Skov AR, Toubro S, Ronn B, Holm L, Astrup A. Randomized trial on protein vs carbohydrate in ad libitum fat reduced diet for the treatment of obesity. Int J Obes Relat Metab Disord 1999;23:528-36

7. Weigle DS, Breen PA, Matthys CC, et al. A high-protein diet induces sustained reductions in appetite, ad libitum caloric intake, and body weight despite compensatory changes in diurnal plasma leptin and ghrelin concentrations. Am J Clin Nutr 2005;82:41-8.

8. Bertenshaw EJ, Lluch A, Yeomans MR. Satiating effects of protein but not carbohydrate consumed in a between-meal beverage context. Physiol Behav 2008;93:427-36.

9. Crovetti R, Porrini M, Santangelo A, Testolin G. The influence of thermic effect of food on satiety. Eur J Clin Nutr 1998;52:482-8.

10. Halton TL, Hu FB. The effects of high protein diets on thermogenesis, satiety and weight loss: a critical review. J Am Coll Nutr 2004;23:373-85.

11. Young VR. Soy protein in relation to human protein and amino acid nutrition. J Am Diet Assoc 1991;91:828-35.

12. Velasquez MT, Bhathena SJ. Role of dietary soy protein in obesity. Int J Med Sci 2007;4:72-82.

13. Anderson GH, Tecimer SN, Shah D, Zafar TA. Protein source, quantity, and time of consumption determine the effect of proteins on short-term food intake in young men. J Nutr 2004;134:3011-5.

14. Spaaij CJ, Pijls LT. New dietary reference intakes in the Netherlands for energy, proteins, fats and digestible carbohydrates. Eur J Clin Nutr 2004;58:191-4.

15. Munro HN. Second Boyd Orr Memorial Lecture. Regulation of body protein metabolism in relation to diet. Proc Nutr Soc 1976;35:297-308.

16. Stunkard AJ, Messick S. The three-factor eating questionnaire to measure dietary restraint, disinhibition and hunger. J Psychosom Res 1985;29:71-83.

17. Westerterp-Plantenga MS, Westerterp KR, Rubbens M, Verwegen CR, Richelet JP, Gardette B. Appetite at "high altitude" [Operation Everest III (Comex-'97)]: a simulated ascent of Mount Everest. J Appl Physiol 1999;87:3919.

18. Harris JA, Benedict FG. A biometric study of basal metabolism in man. Proc Natl Acad Sci 1918;4:370-373.

19. Westerterp KR, Kester AD. Physical activity in confined conditions as an indicator of free-living physical activity. Obes Res 2003;11:865-8.

20. Adam TC, Westerterp-Plantenga MS. Nutrient-stimulated GLP-1 release in normal-weight men and women. Horm Metab Res 2005;37:111-7. 
21. Stubbs RJ, Hughes DA, Johnstone AM, et al. The use of visual analogue scales to assess motivation to eat in human subjects: a review of their reliability and validity with an evaluation of new hand-held computerized systems for temporal tracking of appetite ratings. Br J Nutr 2000;84:405-15.

22. van Eijk HM, Rooyakkers DR, Deutz NE. Rapid routine determination of amino acids in plasma by highperformance liquid chromatography with a 2-3 microns Spherisorb ODS II column. J Chromatogr 1993;620:1438.

23. Senn S. Cross-over trials in Statistics in Medicine: The first '25' years. Statistics in Medicine 2006;25:3430-3442.

24. VanderWeele DA. Insulin is a prandial satiety hormone. Physiol Behav 1994;56:619-22.

25. Woods SC, Chavez M, Park CR, et al. The evaluation of insulin as a metabolic signal influencing behavior via the brain. Neurosci Biobehav Rev 1996;20:139-44.

26. Laidlaw SA, Grosvenor M, Kopple JD. The taurine content of common foodstuffs. JPEN J Parenter Enteral Nutr 1990;14:183-8.

27. Stipanuk MH, Dominy JE, Jr., Lee JI, Coloso RM. Mammalian cysteine metabolism: new insights into regulation of cysteine metabolism. J Nutr 2006;136:1652S-1659S.

28. Ishihara K, Fukuchi Y, Mizunoya W, et al. Amino acid composition of soybean protein increased postprandial carbohydrate oxidation in diabetic mice. Biosci Biotechnol Biochem 2003;67:2505-11.

29. Stipanuk $\mathrm{MH}$. Role of the liver in regulation of body cysteine and taurine levels: a brief review. Neurochem Res 2004;29:105-10.

30. Jeevanandam M, Ramias L, Schiller WR. Altered plasma free amino acid levels in obese traumatized man. Metabolism 1991;40:385-90.

31. Fujihira E, Takahashi H, Nakazawa M. Effect of long-term feeding of taurine in hereditary hyperglycemic obese mice. Chem Pharm Bull (Tokyo) 1970;18:1636-42.

32. Zhang M, Bi LF, Fang JH, et al. Beneficial effects of taurine on serum lipids in overweight or obese non-diabetic subjects. Amino Acids 2004;26:267-71.

33. Thut PD, Hruska RE, Huxtable RJ, Bressler R. Taurine, edited by R.J. Huxtable and A. Barbeau. 1976:357-364.

34. Uhe AM, Collier GR, O'Dea K. A comparison of the effects of beef, chicken and fish protein on satiety and amino acid profiles in lean male subjects. J Nutr 1992;122:467-72. 
Chapter 5

\section{Effects of complete whey-protein breakfasts versus whey without GMP breakfasts on energy intake and satiety}

Veldhorst MAB, Nieuwenhuizen AG, Hochstenbach-Waelen A, Westerterp KR, Engelen MPKJ, Brummer RJM, Deutz NEP, Westerterp-Plantenga MS

Appetite 2009; 52 (2): 388-395 


\section{ABSTRACT}

Aim: To compare the effects of whey versus whey without glycomacropeptide (GMP) in a high and a normal amount of protein in a breakfast custard on satiety and energy intake (EI), taking concentrations of amino acids (AA), glucose, insulin, Glucagon-like Peptide 1 (GLP-1) and ghrelin into account.

Methods: Twenty-five healthy subjects (mean \pm SEM BMI: $23.9 \pm 0.3 \mathrm{~kg} / \mathrm{m}^{2}$; age: $22 \pm 1$ years) received a breakfast containing whey or whey without GMP as protein type with 10/55/35 or 25/55/20 En\% protein/carbohydrate/fat in a randomized, single-blind design. Appetite profile (Visual Analogue Scale, VAS), glucose, insulin, GLP-1, ghrelin and AA concentrations were measured, and the adequate moment for ad lib lunch was determined based on differences in ghrelin concentration. In a second set of experiments subjects received the same breakfasts; $a d$ lib lunch was offered at the pre-determined moment.

Results: After a breakfast with $25 \mathrm{En} \%$ protein increases in insulin and GLP-1 and decreases in ghrelin concentrations were larger; increases in satiety ratings were lower than after $10 \mathrm{En} \%$ $(p<0.05)$; there was a treatment $X$ time interaction effect on glucose and insulin concentrations $(p<0.001)$. After a breakfast with whey without GMP insulin concentrations were increased more than after whey $(p<0.05)$. El at lunch was lower after whey than after whey without GMP (2877 $\pm 165 \mathrm{~kJ}$ vs. $3208 \pm 178 \mathrm{~kJ}, \mathrm{p}<0.05$ ), coinciding with more increased concentrations of serine, threonine, alanine, alpha-aminobutyric acid and isoleucine $(p<0.05)$.

Conclusion: GMP as a whey-fraction reduced energy intake coinciding with increased concentrations of certain amino acids, irrespective of the concentration of whey-protein. Although between different concentrations of whey-protein differences in hormone responses were observed, these were unrelated to satiety ratings or energy intake.

KEYWORDS: $\quad$ satiety, energy intake, whey-protein, glycomacropeptide (GMP), amino acids 


\section{INTRODUCTION}

The increasing incidence of obesity is considered to be a major health problem because it is associated with a number of diseases, including diabetes mellitus type 2 , cardiovascular disease and certain types of cancer $(1,2)$. Obesity is the result of a positive energy balance, which arises when energy intake exceeds energy expenditure. The control of body weight involves several pathways, so weight management requires a multi-factorial approach (3). Recent findings suggest that a relatively high protein intake plays a role in food intake regulation and body weight regulation. A high protein diet has been suggested to increase postprandial and postabsorptive satiety, decrease food intake and preserve a fat-free body mass thereby sustaining energy expenditure (3-6). The importance of satiety particularly appears from a study by Weigle et al., in which a high protein diet reduced ad lib food intake while sustaining satiety at a comfortable level during a 12-week period (6). In order to assess the satiating potential of wheyprotein in particular, the present study focuses on short-term energy intake and satiety.

Milk protein consists of $\sim 20 \%$ of whey-protein which is considered to be a relatively 'fast' protein, i.e. digested and absorbed rapidly (7-11). Whey-protein has been shown to reduce short-term energy intake and affect satiety relative to placebo, carbohydrate and other proteins (12). Whey-protein includes beta-lactoglobulin, alpha-lactalbumin, and glycomacropeptide (GMP) (13). GMP has many biological activities and has been suggested to affect food intake regulation $(12,14-17)$. We therefore investigated whether whey would influence satiety and subsequent energy intake to a larger extent than whey where GMP was removed, referred to as whey and whey without GMP, respectively.

The comparison of effects on food intake from whey and whey without GMP was executed at two different concentrations of whey-protein, as the only protein in the food matrix. The wheyprotein was offered in a breakfast-custard consisting of $20 \%$ of the subject-specific daily energy requirements, with amounts of whey-protein that represent the highest recommended protein intake per day, i.e. $25 \%$ of energy from protein, versus the lowest normal protein intake per day, i.e. $10 \%$ of energy from protein (18).

The aim of the study was to compare the effects of whey versus whey without GMP in a high and a normal amount of protein offered in a breakfast on energy intake and satiety, taking plasma amino acid concentrations, appetite ratings, and concentrations of glucose, insulin, Glucagon-like Peptide 1 (GLP-1), and ghrelin into account.

\section{SUBJECTS AND METHODS}

\section{Subjects}

A power calculation, based on the results of Anderson et al., where a difference in energy intake of $791 \mathrm{~kJ}$ was observed after a preload with whey protein compared with control (19), revealed that a sample size of 25 subjects was needed to be able to determine differences in ad lib energy intake. Thirty healthy male and female volunteers (Body Mass Index $22-30 \mathrm{~kg} / \mathrm{m}^{2}$, age 18 40 years) were recruited by advertisements in local newspapers and on notice boards at the university. They underwent a screening procedure including medical history taking, 
measurement of body weight and height and cognitive restrained eating using a Dutch translation of the Three Factor Eating Questionnaire (TFEQ) $(20,21)$. Twenty-five subjects (11 male, 14 female) were selected on the basis of being in good health, non-smokers, nonvegetarian, not cognitively dietary restraint (TFEQ Factor 1 score $\leq 9$ ), not using medication apart from oral contraceptives and at most moderate alcohol users $(\leq 10$ alcoholic consumptions per week). Their mean age was $22 \pm 1$ years, and their body weight was $74.4 \pm 1.8 \mathrm{~kg}$ (BMI: $23.9 \pm$ $0.3 \mathrm{~kg} / \mathrm{m}^{2}$ ). Five volunteers were not selected because being a vegetarian, smoking or consuming $>10$ alcoholic consumptions per week (1, 2 and 2 volunteers, respectively). Written informed consent was obtained from the participants and the study protocol was approved by the Medical Ethics Committee of the University Hospital Maastricht.

\section{Study design}

A randomized, single-blind, $2 \times 2$ Latin square design was used. All subjects came to the university on four occasions, separated by at least one week. On each test day, subjects received one of the four types of the subject-specific standardized custard breakfast and appetite ratings and blood parameters were obtained. This first part of the study was used in order to determine the moment in time for the subsequent ad lib test meal to be able to show a possible difference in food intake. The adequate moment in time to offer lunch was determined by the latest time point after breakfast where there still were statistically significant differences in the concentrations of the orexigenic hormone ghrelin.

The results of the first part of the study showed that ghrelin concentrations were different at 180 minutes after breakfast $(0.87 \pm 1.01 \mathrm{pmol} / \mathrm{l}$ vs. $-2.78 \pm 1.07 \mathrm{pmol} / \mathrm{l}, \mathrm{p}<0.05$, after whey without GMP $10 \%$ and whey without GMP $25 \%$, respectively), therefore this moment in time was chosen to offer the ad lib lunch in the second set of experiments.

After two months, subjects again came to the university four times in a randomized, single-blind, $2 \times 2$ Latin square design, separated by at least one week. On each test day subjects again received one of the four types of the subject-specific standardized custard breakfast and stayed in the laboratory till ad lib lunch was offered at 180 minutes after breakfast, being the previously determined moment in time.

\section{Breakfast}

Breakfast was offered as a custard, with whey or whey without GMP (whey, Ultra Whey 90, Volactive Functional Food Products, Orwell, United Kingdom; whey without GMP, WPC 80, DMV International, Veghel, The Netherlands) as a single protein source, with either protein/carbohydrate/fat: 10/55/35 En\% (normal protein) or protein/carbohydrate/fat: 25/55/20 En\% (high protein). Protein was exchanged with fat; carbohydrate content was kept constant because of its effect on protein metabolism (22). The four custards all had an energy density of $4 \mathrm{~kJ} / \mathrm{g}$. The breakfast contained $20 \%$ of daily energy requirements, calculated as basal metabolic rate (BMR), according to the equation of Harris-Benedict, multiplied by an activity index of 1.75 which is the average value reported for the general population in the Netherlands $(23,24)$. The mean energy content of the breakfast was $2.52 \pm 0.07 \mathrm{MJ}$ and the provided breakfasts had to be and actually were completely finished within 15 minutes.

The custards were produced by NIZO Food Research bv. (Ede, The Netherlands) and had tapioca starch (Farinex VA50T, AVEBE, Veendam, The Netherlands and Perfectamyl 3108 AVEBE, 
Veendam, The Netherlands) and sunflower oil (Reddy, NV Vandemoortele, Roosendaal, The Netherlands) as the carbohydrate and fat sources and were citrus-vanilla (Citrus, J.B. de lange, Belfeld, The Netherlands; Vanilla, J.B. de lange, Belfeld, The Netherlands) flavored. Extensive product development and use of a trained taste panel with healthy male and female volunteers lead to custards that did not differ significantly in color, taste or viscosity. The amino acid composition of the custards is presented in table 1.

Lunch

According to a normal Dutch lunch consisting of bread and a filling, the ad lib lunch consisted of Turkish bread ( $400 \mathrm{~g}$ ) with egg salad (400 g) with 13/41/46 En\% protein/carbohydrate/fat with an energy density of $11.4 \mathrm{~kJ} / \mathrm{g}$. Beforehand it was tested whether all subjects liked the lunch sufficiently. Lunch was prepared by the research staff and served as one large Turkish bread with egg salad equally spread over it. Lunch was offered in excess and all subjects were served the same amount of lunch and were instructed to eat till they were comfortably full. None of the subjects finished the offered lunch completely nor asked for more.

Table 1 Amino acid content of the breakfasts given as a custard with either $10 \mathrm{En} \%$ or $25 \mathrm{En} \%$ from whey- or whey without GMP-protein (g amino acids/100 g custard)

\begin{tabular}{lcccc}
\hline & whey & whey & whey without GMP & whey without GMP \\
& $10 \%$ & $25 \%$ & $10 \%$ & $25 \%$ \\
& & & & 0.922 \\
Glutamic acid $^{\text {a }}$ & 0.381 & 0.957 & 0.378 & 0.615 \\
Aspartic acid $^{b}$ & 0.230 & 0.579 & 0.252 & 0.172 \\
Cysteine $^{\text {Serine }}$ & 0.055 & 0.139 & 0.071 & 0.216 \\
Histidine & 0.099 & 0.249 & 0.088 & 0.115 \\
Glycine & 0.039 & 0.097 & 0.047 & 0.092 \\
Threonine & 0.035 & 0.088 & 0.038 & 0.259 \\
Arginine & 0.150 & 0.378 & 0.106 & 0.164 \\
Alanine & 0.055 & 0.139 & 0.067 & 0.255 \\
Tyrosine & 0.106 & 0.266 & 0.105 & 0.192 \\
Valine & 0.061 & 0.154 & 0.079 & 0.275 \\
Methionine & 0.123 & 0.309 & 0.113 & 0.125 \\
Isoleucine & 0.048 & 0.121 & 0.051 & 0.307 \\
Phenylalanine & 0.141 & 0.355 & 0.126 & 0.189 \\
Tryptophan & 0.062 & 0.156 & 0.078 & 0.123 \\
Leucine & 0.039 & 0.099 & 0.050 & 0.675 \\
Lysine & 0.226 & 0.567 & 0.277 & 0.560 \\
Proline & 0.201 & 0.504 & 0.230 & 0.238 \\
Branched-chain amino acids & 0.128 & 0.321 & 0.097 & 1.257 \\
Large neutral amino acids & 0.490 & 1.232 & 0.515 & 1.570 \\
& 0.592 & 1.487 & 0.643 & \\
\hline & & & &
\end{tabular}

\footnotetext{
${ }^{a}$ Glutamic acid = glutamine + glutamate

${ }^{\mathrm{b}}$ Aspartic acid $=$ asparagine
} 


\section{Study protocol}

In the first set of experiments the protocol started at $08.00 \mathrm{~h}$ after an overnight fast from $22.00 \mathrm{~h}$. A Venflon catheter was placed in a superficial dorsal vein of the hand for blood sampling. To obtain arterialized venous blood samples the hand was placed in a thermostatically controlled hot box at $60^{\circ} \mathrm{C}$ for 20 minutes before the sampling time. A basal blood sample was taken and appetite ratings were scored. After 5 minutes a second basal blood sample was obtained and breakfast was offered ( $\mathrm{t}=0$ minutes). After the first and the last bite, taste perception was scored. Appetite ratings were completed just before breakfast and at 20, 40,60,80, 100, 120, 180 and 240 minutes after breakfast. Blood samples for urea and amino acid determination were obtained at -5 minutes and subsequently just after the appetite ratings; blood samples for determination of glucose, insulin and ghrelin concentrations were obtained before and 40,60, 120, and 180 minutes after breakfast, also just after the appetite ratings at those time points. Venous blood samples for determination of GLP-1 concentration were obtained separately before, and at 30,60,90,120, and 180 minutes after breakfast by means of a Venflon catheter placed in an antecubital vein (25). Subjects were allowed to drink two glasses of water spread over the morning.

In the second set of experiments, the protocol started after an overnight fast from $22.00 \mathrm{~h}$ at $8.30 \mathrm{~h}$ with scoring appetite ratings. Breakfast was offered ( $\mathrm{t}=0$ minutes) and completed within 15 minutes. Lunch was offered at the previously determined moment in time, 180 minutes after breakfast. Subjects were allowed to drink three glasses of water spread over the entire test period.

\section{Measurements}

\section{Appetite profile}

To determine the appetite profile, hunger, fullness, satiety and desire to eat were rated on 100 $\mathrm{mm}$ Visual Analogue Scales (VAS), anchored with 'not at all' and 'extremely' during the test day (26). Subjects were instructed to rate themselves by marking the scale at the point that was most appropriate to their feeling at that time. The distance from the left end of the scale to the mark was measured in $\mathrm{mm}$; changes from baseline $(\Delta)$ were calculated by subtracting the baseline score ( -5 minutes) from the score at a certain time point.

\section{Taste perception}

Taste perception profiles of the custards were assessed after the first and the last bite of the breakfast using $100 \mathrm{~mm}$ Visual Analogue Scales (VAS), anchored with 'not at all' and 'extremely' on the aspects: pleasantness, sweetness, sourness, saltiness, bitterness, savouriness, crispiness and creaminess.

\section{Blood parameters}

Blood was distributed into EDTA tubes for glucose, insulin, and ghrelin measurement. For GLP-1 measurement blood was collected in EDTA tubes with added dipeptidyl peptidase IV inhibitor. For amino acid and urea determination, blood was collected in lithium heparin tubes. Blood samples were centrifuged at $4^{\circ} \mathrm{C}$ for 10 minutes at $3000 \mathrm{rpm}$. Hydrochloric acid and 
phenylmethylsulfonyl fluoride were added to plasma for active ghrelin determination. For amino acid analysis, $250 \mu \mathrm{l}$ plasma was deproteinized by mixing it with $20 \mathrm{mg}$ dry sulfosalicylic acid. For analysis of urea, $200 \mu \mathrm{l}$ plasma was deproteinized by mixing it with $20 \mu \mathrm{l}$ of a $500 \mathrm{~g} / \mathrm{l}$ trichloroacetic acid solution. All samples were stored at $-80^{\circ} \mathrm{C}$ until further analysis. Plasma glucose concentrations were determined using the hexokinase method (Glucose HK 125 kit, ABX diagnostics, Montpellier, France). Insulin concentrations were measured by RIA (Linco Research Inc., St. Charles, Missouri, USA). Plasma active ghrelin concentrations were measured by ELISA (Linco Research Inc., St. Charles, Missouri, USA). Plasma active GLP-1 samples were analyzed using ELISA (EGLP-35K; Linco Research Inc., St. Charles, Missouri, USA). Plasma concentrations of amino acids were determined with the use of a fully automated HPLC (Pharmacia, Woerden, The Netherlands), after precolumn derivatization with o-phthaldialdehyde (27). Plasma urea was analyzed spectrophotometrically on a COBAS Mira S (Roche Diagnostica, Hoffman-La Roche, Basel, Switzerland).

\section{Energy intake (EI)}

The food provided for lunch was weighed before and after eating and El was calculated by multiplying the amount of food consumed by the energy value of the food as indicated by the product labels $(11.4 \mathrm{~kJ} / \mathrm{g})$.

\section{Statistical analysis}

Data are presented as mean changes from baseline \pm standard error to the mean (SEM), unless otherwise indicated (28). The area under the curve (AUC) or the area above the curve (AAC, for ghrelin) of changes from baseline over time was calculated using the trapezoidal method.

After the first set of experiments, a $2 \times 2$ repeated measures ANOVA was carried out to test for the effects of protein concentration, protein type and interaction between protein concentration and protein type on the AUCs of satiety ratings, glucose, insulin, GLP-1, ghrelin, amino acids and urea concentrations. Moreover, a three-way ANOVA was carried out to test for the effects of protein type, protein concentration, time and interaction between protein concentration, protein type and/or time on satiety ratings, glucose, insulin, GLP-1 and ghrelin. A Fisher's PLSD post-hoc correction was used to determine differences between different time points. Since changes in ghrelin concentration were used to determine the moment in time to offer lunch, an ANOVA repeated measures per time point was used to assess possible differences between the different breakfasts at each time point.

After the second set of experiments, again a 2x2 repeated measures ANOVA was carried out to test for the effects of protein concentration, protein type and interaction between protein concentration and protein type on energy intake at lunch. A p-value $<0.05$ was regarded as statistically significant. Statistical procedures were performed using StatView 5.0 (SAS Institute Inc., USA, 1998).

\section{RESULTS}

Baseline satiety ratings and concentrations of glucose, insulin, GLP-1, ghrelin, amino acids or urea were not different between treatments (table 2). 
Table 2 Baseline values of satiety scores, and glucose, insulin, GLP-1, ghrelin, amino acid and urea concentrations before consumption of a custard-breakfast with either $10 \mathrm{En} \%$ of $25 \mathrm{En} \%$ from whey- or whey without GMP-protein in 25 subjects (men and women)

\begin{tabular}{|c|c|c|c|c|}
\hline \multirow[b]{3}{*}{ Satiety (mmVAS) } & whey & whey & whey without GMP & whey without GMP \\
\hline & $10 \%$ & $25 \%$ & $10 \%$ & $25 \%$ \\
\hline & $17 \pm 3$ & $19 \pm 4$ & $16 \pm 3$ & $23 \pm 4$ \\
\hline Glucose (mmol/l) & $5.27 \pm 0.11$ & $5.18 \pm 0.06$ & $5.18 \pm 0.07$ & $5.19 \pm 0.07$ \\
\hline Insulin (mU/I) & $13.76 \pm 0.89$ & $13.41 \pm 0.69$ & $13.01 \pm 0.57$ & $16.93 \pm 2.52$ \\
\hline GLP-1 (pmol/I) & $4.40 \pm 2.69$ & $4.10 \pm 2.59$ & $4.80 \pm 2.79$ & $4.90 \pm 2.80$ \\
\hline Ghrelin (pmol/l) & $7.92 \pm 0.90$ & $10.60 \pm 0.80$ & $9.70 \pm 0.90$ & $9.57 \pm 1.30$ \\
\hline Glutamate $(\mu \mathrm{mol} / \mathrm{I})$ & $105 \pm 4$ & $103 \pm 3$ & $96 \pm 2$ & $104 \pm 2$ \\
\hline Asparagine $(\mu \mathrm{mol} / \mathrm{I})$ & $58 \pm 2$ & $58 \pm 3$ & $55 \pm 2$ & $55 \pm 1$ \\
\hline Serine $(\mu \mathrm{mol} / \mathrm{I})$ & $132 \pm 6$ & $133 \pm 5$ & $132 \pm 6$ & $136 \pm 6$ \\
\hline Glutamine $(\mu \mathrm{mol} / \mathrm{l})$ & $512 \pm 16$ & $511 \pm 11$ & $490 \pm 11$ & $524 \pm 17$ \\
\hline Histidine $(\mu \mathrm{mol} / \mathrm{I})$ & $92 \pm 2$ & $94 \pm 3$ & $95 \pm 4$ & $97 \pm 3$ \\
\hline Glycine $(\mu \mathrm{mol} / \mathrm{l})$ & $231 \pm 13$ & $236 \pm 10$ & $210 \pm 8$ & $226 \pm 11$ \\
\hline Threonine $(\mu \mathrm{mol} / \mathrm{l})$ & $140 \pm 7$ & $147 \pm 8$ & $137 \pm 6$ & $139 \pm 5$ \\
\hline Citrulline ( $\mu \mathrm{mol} / \mathrm{l})$ & $30 \pm 1$ & $30 \pm 1$ & $29 \pm 1$ & $30 \pm 1$ \\
\hline Arginine $(\mu \mathrm{mol} / \mathrm{I})$ & $85 \pm 4$ & $86 \pm 3$ & $83 \pm 2$ & $88 \pm 4$ \\
\hline Alanine $(\mu \mathrm{mol} / \mathrm{l})$ & $293 \pm 13$ & $290 \pm 17$ & $283 \pm 9$ & $305 \pm 19$ \\
\hline Taurine $(\mu \mathrm{mol} / \mathrm{l})$ & $32 \pm 1$ & $32 \pm 1$ & $31 \pm 1$ & $32 \pm 1$ \\
\hline Alpha-aminobutyric acid ( $\mu \mathrm{mol} / \mathrm{l})$ & $16 \pm 1$ & $15 \pm 1$ & $16 \pm 1$ & $18 \pm 1$ \\
\hline Tyrosine $(\mu \mathrm{mol} / \mathrm{l})$ & $55 \pm 2$ & $57 \pm 3$ & $52 \pm 2$ & $54 \pm 2$ \\
\hline Valine $(\mu \mathrm{mol} / \mathrm{l})$ & $176 \pm 6$ & $188 \pm 5$ & $172 \pm 4$ & $178 \pm 5$ \\
\hline Methionine $(\mu \mathrm{mol} / \mathrm{I})$ & $24 \pm 1$ & $27 \pm 2$ & $24 \pm 1$ & $25 \pm 1$ \\
\hline Isoleucine $(\mu \mathrm{mol} / \mathrm{I})$ & $96 \pm 26$ & $66 \pm 2$ & $61 \pm 1$ & $67 \pm 2$ \\
\hline Phenylalanine $(\mu \mathrm{mol} / \mathrm{l})$ & $49 \pm 1$ & $49 \pm 1$ & $48 \pm 1$ & $50 \pm 1$ \\
\hline Tryptophan ( $\mu \mathrm{mol} / \mathrm{l})$ & $49 \pm 1$ & $48 \pm 1$ & $47 \pm 1$ & $48 \pm 1$ \\
\hline Leucine $(\mu \mathrm{mol} / \mathrm{l})$ & $113 \pm 4$ & $114 \pm 3$ & $107 \pm 2$ & $113 \pm 3$ \\
\hline Ornithine $(\mu \mathrm{mol} / \mathrm{l})$ & $61 \pm 6$ & $54 \pm 3$ & $52 \pm 2$ & $53 \pm 2$ \\
\hline Lysine $(\mu \mathrm{mol} / \mathrm{l})$ & $152 \pm 6$ & $157 \pm 5$ & $148 \pm 4$ & $151 \pm 4$ \\
\hline Branched-chain amino acids $(\mu \mathrm{mol} / \mathrm{l}$ & $386 \pm 26$ & $368 \pm 10$ & $340 \pm 7$ & $358 \pm 8$ \\
\hline Large neutral amino acids ( $\mu \mathrm{mol} / \mathrm{l})$ & $490 \pm 26$ & $475 \pm 11$ & $441 \pm 8$ & $463 \pm 10$ \\
\hline Sum amino acids $(\mu \mathrm{mol} / \mathrm{l})$ & $2503 \pm 66$ & $2497 \pm 58$ & $2369 \pm 35$ & $2494 \pm 54$ \\
\hline Urea $(\mathrm{mmol} / \mathrm{l})$ & $3.77 \pm 0.16$ & $4.02 \pm 0.20$ & $3.91 \pm 0.18$ & $3.87 \pm 0.17$ \\
\hline
\end{tabular}

Values are means \pm SEM, $2 \times 2$ ANOVA for effects of protein concentration, protein type and interaction of protein concentration and protein type, no significant differences

\section{Taste perception}

The pleasantness of taste of the breakfasts was $59 \pm 3$ mmVAS for the whey $10 \%$ breakfast, $67 \pm$ 4 mmVAS for the whey $25 \%$ breakfast, $53 \pm 4$ mmVAS for the whey without GMP $10 \%$ breakfast, and $58 \pm 3$ mmVAS for the whey without GMP $25 \%$ breakfast (ns).

\section{Satiety}

There was no interaction effect of protein concentration $x$ protein type on the satiety response expressed as AUC and there were no effects of protein concentration or protein type on the AUC of satiety. 
With respect to changes in satiety ratings over time, there was no interaction effect of protein concentration $\mathrm{x}$ protein type $\mathrm{x}$ time. Moreover, there was no interaction effect of protein concentration $x$ protein type, protein concentration $x$ time or protein type $x$ time. However, satiety ratings were more increased after a breakfast with $10 \%$ of energy from protein than after a breakfast with $25 \%$ of energy from protein ( $<<0.05$, figure 1 ) and were different between all time points ( $p<0.001$ all, figure 1), except for time point 20 and 40,40 and 60,60 and 80,80 and 100 and 100 and 120 . There was no effect of protein type.

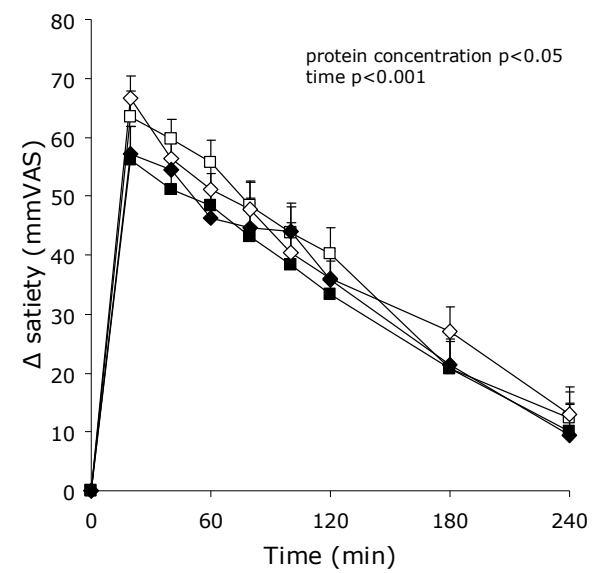

Figure 1 Changes in satiety ratings (mmVAS) after a breakfast offered as a custard with either $10 \mathrm{En} \%$ or $25 \mathrm{En} \%$ from whey- or whey without GMP-protein expressed as delta compared to baseline in 25 subjects (men and women). Values are mean + SEM. $\square$ whey $10 \%$, $\mathbf{\square}$ whey $25 \%$, $\diamond$ whey without GMP $10 \%$, whey without GMP $25 \%$

Three-way ANOVA with Fisher's PLSD post-hoc correction for multiple comparisons showed an effect of protein concentration $(p<0.05)$ and time $(p<0.001)$ on satiety ratings (differences between all time points $(p<0.001)$, except for time point 20 and 40,40 and 60,60 and 80,80 and 100 and 100 and 120 ).

\section{Glucose}

There was no interaction effect of protein concentration $\mathrm{x}$ protein type on the glucose response expressed as AUC, and there were no effects of protein concentration or protein type on the AUC of glucose.

With respect to changes in glucose concentration over time, there was no interaction effect of protein concentration $x$ protein type $x$ time. Moreover, there was no interaction effect of protein concentration $x$ protein type or protein type $x$ time, whereas there was a protein concentration $x$ time interaction effect $(p<0.001$, figure 2A). After the initial increase and subsequent decrease, glucose concentrations remained higher after a breakfast with $25 \%$ of energy from protein than after a breakfast with $10 \%$ of energy from protein $(p<0.001$, figure $2 A)$. 
Furthermore, glucose concentrations were different between all time points $(p<0.001$ all, figure $2 \mathrm{~A})$, except for time point 0 and 180 . There was no effect of protein type.

\section{Insulin}

There was no interaction effect of protein concentration $x$ protein type on the insulin response expressed as AUC, and there was no effect of protein type on the AUC of insulin. However, the insulin response was more increased after a breakfast with $25 \%$ of energy from protein than after a breakfast with $10 \%$ of energy from protein $(p<0.001)$.

With respect to changes in insulin concentration over time, there was no interaction effect of protein concentration $x$ protein type $x$ time. Moreover, there was no interaction effect of protein concentration $x$ protein type or protein type $x$ time, whereas there was a protein concentration $x$ time interaction effect $(p<0.001$, figure 2B). Insulin concentrations increased more and decreased slower thereafter after a breakfast with $25 \%$ of energy from protein than after a breakfast with $10 \%$ of energy from protein ( $\mathrm{p}<0.001$, figure $2 \mathrm{~B}$ ). Insulin concentrations were more increased after a breakfast with $25 \%$ of energy from protein than after a breakfast with $10 \%$ of energy from protein $(p<0.001$, figure $2 B$ ) and were more increased after a breakfast with whey without GMP than after a breakfast with whey $(\mathrm{p}<0.05$, figure $2 \mathrm{~B})$. Furthermore, insulin concentrations were different between all time points ( $p<0.001$ all, figure $2 B)$, except for time point 0 compared with 180 .

\section{GLP-1}

There was no interaction effect of protein concentration x protein type on the GLP-1 response expressed as AUC, and there were no effects of protein concentration or protein type on the AUC of GLP-1.

With respect to changes in GLP-1 concentration over time, there was no interaction effect of protein concentration $\mathrm{x}$ protein type $\mathrm{x}$ time. Moreover, there was no interaction effect of protein concentration $x$ protein type, protein concentration $x$ time or protein type $x$ time. However, GLP-1 concentrations were more increased after a breakfast with $25 \%$ of energy from protein than after breakfast with $10 \%$ of energy from protein $(p<0.05$, figure $2 \mathrm{C}$ ) and GLP-1 concentrations were different between all time points ( $p<0.05$ all, figure $2 \mathrm{C}$ ), except for time point 0 and 180, 90 and 120 and 120 and 180 .

\section{Ghrelin}

There was no interaction effect of protein concentration $\mathrm{x}$ protein type on the ghrelin response expressed as AAC, and there was no effect of protein type on the AUC of ghrelin. However, the ghrelin response was more decreased after a breakfast with $25 \%$ of energy from protein than after a breakfast with $10 \%$ of energy from protein $(p<0.01)$.

With respect to changes in ghrelin concentration over time, there was no interaction effect of protein concentration $\mathrm{x}$ protein type $\mathrm{x}$ time. Moreover, there was no interaction effect of protein concentration $x$ protein type, protein concentration $x$ time or protein type $x$ time. However, ghrelin concentrations were more decreased after a breakfast with $25 \%$ of energy from protein than after a breakfast with $10 \%$ of energy from protein $(p<0.001$, figure $2 \mathrm{D}$ ) and ghrelin concentrations were different between all time points ( $p<0.05$ all, figure $2 D$ ), except for time point 0 and 180,40 and 60 and 40 and 120 . 
Analysis per time point revealed that ghrelin concentration was more decreased after a breakfast with $25 \%$ of energy from whey without GMP than after a breakfast with $10 \%$ of energy from whey without GMP at 180 minutes after breakfast ( $p<0.05$, figure 2D).

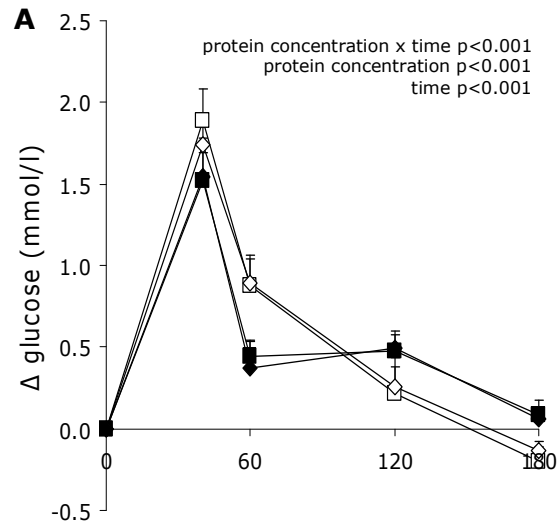

Time $(\min )$

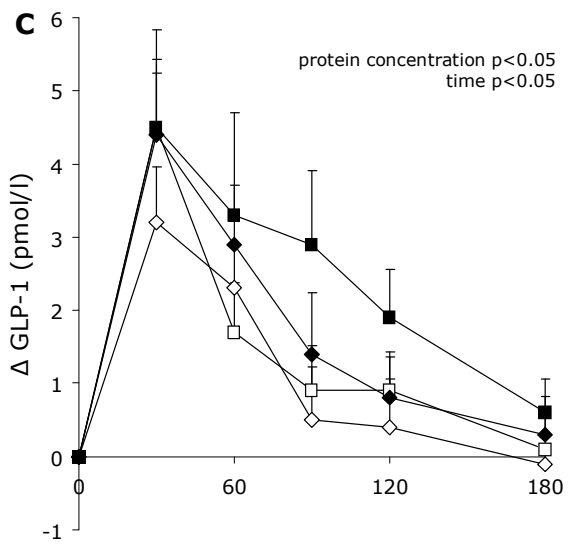

Time (min)
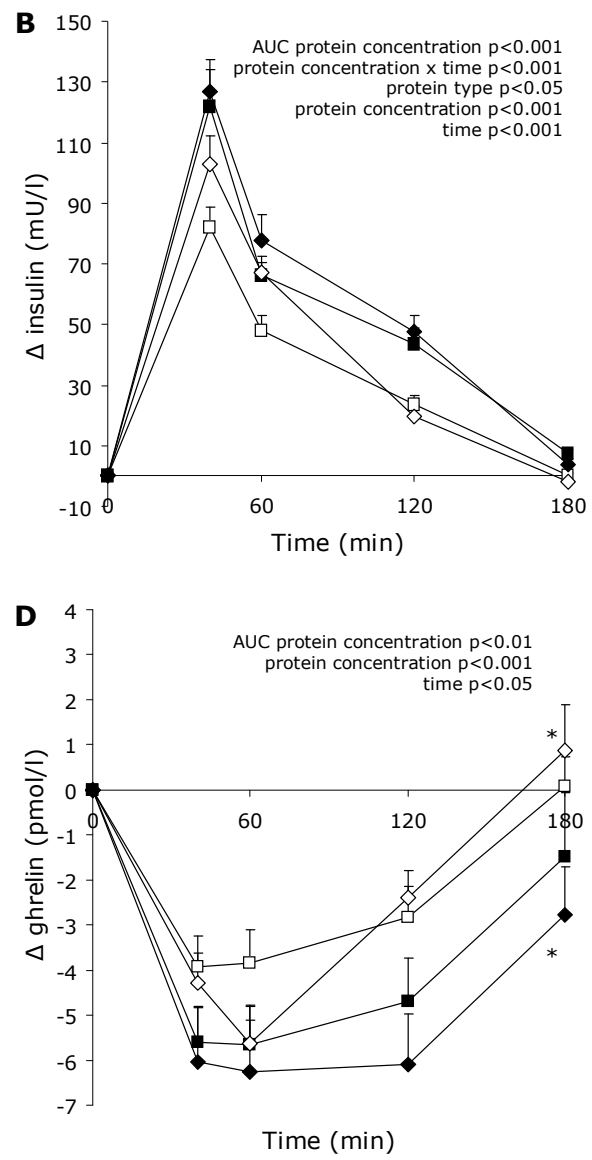

Figure 2 Changes in glucose (mmol/l, A), insulin (mU/l, B), GLP-1 (pmol/l, C) and ghrelin concentrations (pmol/I, D) after a breakfast offered as a custard with either $10 \mathrm{En} \%$ or $25 \mathrm{En \%}$ from whey- or whey without GMP-protein expressed as delta compared to baseline in 25 subjects (men and women). Values are mean + SEM. $\square$ whey $10 \%, \square$ whey $25 \%, \diamond$ whey without GMP 10\%, whey without GMP 25\%. Three-way ANOVA with Fisher's PLSD post-hoc correction for multiple comparisons showed a protein concentration $x$ time interaction effect $(p<0.001)$ and an effect of time $(p<0.001)$ on glucose concentration (differences between all time points ( $p<0.001$ ), except for time point 0 and 180). There was an effect of protein level on the AUC of insulin $(p<0.001)$ and a protein concentration $x$ time interaction effect $(p<0.001)$ and an effect of protein level $(p<0.001)$, protein type $(p<0.05)$ and time $(p<0.001)$ on insulin concentration (differences between all time points $(p<0.01)$, except for time point 0 and 180$)$. There was an effect of protein level $(p<0.05)$ and time $(p<0.001)$ on $G L P$ concentration (differences between all time points ( $p<0.05$ ), except for time point 0 and 180,90 and 120 and 120 and 180 ). There was an effect of protein level on the AAC of ghrelin $(p<0.001)$ and an effect of protein level $(p<0.05)$ and time $(p<0.001)$ on ghrelin concentration (differences at all time points $(p<0.05)$, except for time point 0 and 180,40 and 60 and 40 and 120). At 180 minutes, ghrelin concentration was more decreased after whey without GMP $25 \%$ than after whey without GMP $10 \%\left(p<0.05^{*}\right)$. 


\section{Amino acids}

There was a protein concentration $x$ protein type interaction effect on the concentrations of glutamate $(p<0.01)$, threonine $(p<0.001)$, alpha-aminobutyric acid $(p<0.05)$, valine $(p<0.001)$, isoleucine $(p<0.001)$, branched-chain amino acids $(p<0.01)$, large neutral amino acids $(p<0.05)$ and sum amino acids ( $p<0.05$, table 3 ).

Responses of all amino acids were more increased after a breakfast with $25 \%$ of energy from protein than after a breakfast with $10 \%$ of energy ( $p<0.001$ all, table 3 ) except for glycine and taurine (table 3$)$. Concentrations of serine $(p<0.01)$, threonine $(p<0.001)$, alanine $(p<0.01)$, alphaaminobutyric acid $(p<0.01)$, and isoleucine $(p<0.001)$ were more increased after a breakfast with whey than after a breakfast with whey without GMP (table 3), whereas concentrations of citrulline $(p<0.05)$, arginine $(p<0.01)$, tyrosine $(p<0.001)$, phenylalanine $(p<0.001)$, tryptophan $(p<0.001)$, leucine $(p<0.001)$, and lysine $(p<0.001)$ were more increased after a breakfast with whey without GMP than after a breakfast with whey (table 3).

\section{Energy intake at lunch}

There was no interaction effect of protein type $x$ session on energy intake at lunch. Mean energy intake at the first visit was $3125 \pm 162 \mathrm{~kJ}$ whereas on the fourth visit mean energy intake was $2974 \pm 179 \mathrm{~kJ}$ (ns). There was no interaction effect of protein concentration $\mathrm{x}$ protein type on energy intake at lunch, and there was no effect of protein concentration. However, protein type did have an effect on ad lib energy intake at lunch. Energy intake at lunch was lower after a breakfast with whey than after a breakfast with whey without GMP (2877 \pm 167 vs. $3208 \pm 180$ $k J, p<0.05)$. 
Table 3 Amino acid ( $\mu \mathrm{mol} / \mathrm{l} . \mathrm{h}$ ) and urea (mmol/I.h) responses expressed as Area Under the Curve after a breakfast offered as a custard with either $10 \mathrm{En} \%$ of $25 \mathrm{En \%}$ from whey- or whey without GMP-protein in 25 subjects (men and women)

\begin{tabular}{|c|c|c|c|c|c|c|c|}
\hline & $\begin{array}{l}\text { whey } \\
10 \%\end{array}$ & $\begin{array}{l}\text { whey } \\
25 \%\end{array}$ & $\begin{array}{l}\text { whey without } \\
\text { GMP } 10 \%\end{array}$ & $\begin{array}{l}\text { whey without } \\
\text { GMP } 25 \%\end{array}$ & $\begin{array}{l}\text { p-value } \\
\text { conc. }\end{array}$ & $\begin{array}{l}\mathrm{p} \text {-value } \\
\text { type }\end{array}$ & $\begin{array}{l}\mathrm{p} \text {-value } \\
\text { interact }\end{array}$ \\
\hline Glutamate & $-1028 \pm 442$ & $3705 \pm 517$ & $266 \pm 337$ & $2163 \pm 381$ & $<0.001$ & 0.766 & 0.001 \\
\hline Asparagine & $3925 \pm 337$ & $10122 \pm 382$ & $3977 \pm 313$ & $9195 \pm 454$ & $<0.001$ & 0.237 & 0.187 \\
\hline Serine & $2960 \pm 491$ & $9178 \pm 889$ & $1354 \pm 606$ & $6038 \pm 743$ & $<0.001$ & 0.001 & 0.265 \\
\hline Glutamine & $2220 \pm 1235$ & $12156 \pm 1655$ & $1800 \pm 1045$ & $7146 \pm 1676$ & $<0.001$ & 0.055 & 0.104 \\
\hline Histidine & $832 \pm 248$ & $3311 \pm 305$ & $1418 \pm 360$ & $3356 \pm 260$ & $<0.001$ & 0.280 & 0.355 \\
\hline Glycine & $-2307 \pm 666$ & $-2759 \pm 1044$ & $-2346 \pm 663$ & $-4686 \pm 914$ & 0.092 & 0.234 & 0.253 \\
\hline Threonine & $12828 \pm 349$ & $34393 \pm 1284$ & $8484 \pm 588$ & $21892 \pm 1154$ & $<0.001$ & $<0.001$ & $<0.001$ \\
\hline Citrulline & $-1487 \pm 156$ & $-33 \pm 136$ & $-919 \pm 149$ & $203 \pm 116$ & $<0.001$ & 0.004 & 0.229 \\
\hline Arginine & $379 \pm 279$ & $5327 \pm 404$ & $1497 \pm 421$ & $6292 \pm 309$ & $<0.001$ & 0.004 & 0.828 \\
\hline Alanine & $36193 \pm 1383$ & $49814 \pm 2859$ & $31910 \pm 2111$ & $38665 \pm 3059$ & $<0.001$ & 0.002 & 0.155 \\
\hline Taurine & $-131 \pm 80$ & $137 \pm 132$ & $-70 \pm 118$ & $-68 \pm 81$ & 0.194 & 0.487 & 0.198 \\
\hline $\begin{array}{l}\text { Alpha-aminobutyric } \\
\text { acid }\end{array}$ & $571 \pm 76$ & $1262 \pm 111$ & $507 \pm 88$ & $793 \pm 96$ & $<0.001$ & 0.004 & 0.029 \\
\hline Tyrosine & $-205 \pm 174$ & $6452 \pm 565$ & $1973 \pm 373$ & $9980 \pm 583$ & $<0.001$ & $<0.001$ & 0.133 \\
\hline Valine & $6487 \pm 504$ & $34006 \pm 1327$ & $6786 \pm 1125$ & $24916 \pm 1072$ & $<0.001$ & $<0.001$ & $<0.001$ \\
\hline Methionine & $868 \pm 224$ & $4354 \pm 514$ & $1319 \pm 171$ & $4297 \pm 327$ & $<0.001$ & 0.549 & 0.442 \\
\hline Isoleucine & $9387 \pm 303$ & $31195 \pm 1133$ & $7865 \pm 465$ & $22388 \pm 1152$ & $<0.001$ & $<0.001$ & $<0.001$ \\
\hline Phenylalanine & $-178 \pm 123$ & $3298 \pm 203$ & $1193 \pm 280$ & $4379 \pm 222$ & $<0.001$ & $<0.001$ & 0.492 \\
\hline Tryptophan & $1558 \pm 180$ & $7214 \pm 281$ & $3241 \pm 145$ & $8408 \pm 474$ & $<0.001$ & $<0.001$ & 0.407 \\
\hline Leucine & $10219 \pm 373$ & $40815 \pm 1502$ & $16262 \pm 586$ & $46428 \pm 2256$ & $<0.001$ & $<0.001$ & 0.877 \\
\hline Ornithine & $-700 \pm 1398$ & $3390 \pm 382$ & $1501 \pm 217$ & $2967 \pm 267$ & $<0.001$ & 0.227 & 0.075 \\
\hline Lysine & $16328 \pm 663$ & $43270 \pm 1231$ & $20146 \pm 909$ & $46139 \pm 1996$ & $<0.001$ & 0.010 & 0.719 \\
\hline $\begin{array}{l}\text { Branched-chain amino } \\
\text { acids }\end{array}$ & $18736 \pm 6020$ & $106016 \pm 3703$ & $30914 \pm 2087$ & $93733 \pm 4377$ & $<0.001$ & 0.990 & 0.004 \\
\hline $\begin{array}{l}\text { Large neutral amino } \\
\quad \text { acids }\end{array}$ & $25709 \pm 1135$ & $115766 \pm 4172$ & $34080 \pm 2674$ & $108092 \pm 4992$ & $<0.001$ & 0.240 & 0.044 \\
\hline Sum amino acids & $91364 \pm 6611$ & $300607 \pm 11430$ & $108164 \pm 8655$ & $260891 \pm 11934$ & $<0.001$ & 0.921 & 0.024 \\
\hline Urea & $-19 \quad 11$ & $119 \pm 11$ & $-23 \pm 14$ & $152 \pm 13$ & $<0.001$ & 0.226 & 0.126 \\
\hline
\end{tabular}

Values are means \pm SEM, $2 \times 2$ ANOVA for effects of protein concentration, protein type and interaction of protein concentration and protein type

\section{DISCUSSION}

Ad lib energy intake at lunch was $\sim 10 \%$ lower after a breakfast with whey than after a breakfast with whey without GMP, irrespective of the protein concentration of the breakfast. The citrusvanilla flavored custards were similar to custards widely available and often consumed in the Netherlands. It is therefore unlikely that unfamiliarity with the breakfasts influenced satiety responses. After being tested by a professional taste panel of NIZO Food Research, taste perception and hedonic values again were evaluated by the subjects and were excluded to affect appetite profile ratings differently. In the second set of experiments subjects underwent four sessions were energy intake was measured. These sessions were separated by at least one week and were fully randomized. There was no significant order effect; moreover the study design was single-blind and randomized design. Although changes in blood parameters and effects on subsequent energy intake were measured in two separate studies, both studies were conducted in the same subjects using the same breakfasts. Therefore, it would not be expected that the changes in blood parameters are different between the two studies.

GMP has many biological activities, for instance an increased pancreatic secretion of digestive peptides, and has been suggested to affect food intake regulation $(14,16,17,29)$. However, 
GMP alone had no effect on subsequent energy intake or subjective indicators of satiety in an experiment with healthy humans consuming beverages with $0.4 \%$ or $2.0 \%$ GMP (15). BurtonFreeman reported that the presence or absence of GMP in whey offered as a preload had no remarkable effects on satiety, CCK release or food intake at a test meal (30). Our results however show that GMP as part of whey-protein in a breakfast lowered subsequent energy intake at lunch with $\sim 10 \%$ compared with a breakfast with whey-protein without GMP. The absence of differences in satiety and food intake in the study of Burton-Freeman may be caused by the high protein content of the preload; $44 \%$ of energy from protein. Protein, that has been shown to be the most satiating macronutrient (31), at such a high level probably induces an elevated satiety response regardless of the presence or absence of GMP. Furthermore, the timing of the measurement of food intake is of major importance (19) and may explain differences in results. A lunch test meal was provided to the subjects at 75 minutes after the preload; this time point was not underscored by appetite ratings, amino acid or hormone concentrations (30). In the present study first the adequate moment in time was determined, using the same breakfasts, and appeared to be 180 minutes after the breakfast, based upon significant differences in ghrelin concentrations. Ghrelin has been suggested to play a physiological role in meal initiation in humans (32). Differences in ghrelin concentrations may therefore result in differences in energy intake. Therefore in the present study the choice of the moment in time to offer lunch was based on the latest time point where there were differences in ghrelin concentrations.

Several amino acids were increased more after the breakfast with whey than after the breakfast with whey without GMP regardless protein concentration, namely serine, threonine, alanine, alpha-aminobutyric acid and isoleucine. It may be hypothesized that these amino acids play a role in the reduction of food intake, what relates to the classic aminostatic theory from Mellinkoff that states that a rise in amino acid concentration is accompanied by a diminishing of appetite and that a subsequent increase of appetite is coincided with a fall in amino acid concentration (33). Further research is needed to draw conclusions on a possible effect of serine, threonine, alanine, alpha-aminobutyric acid and isoleucine on energy intake. The differences in amino acid concentrations between whey and whey without GMP reflect the differences in amino acid composition of the breakfasts and support the difference in energy intake at lunch at 180 minutes after breakfast.

With respect to the effects of a high and normal amount of protein relatively larger increases in insulin and GLP-1 and larger decreases in ghrelin concentrations appeared after a breakfast with $25 \%$ of energy from whey-protein than after a breakfast with $10 \%$ of energy. So a breakfast with a high amount of whey-protein showed stronger physiological responses in terms of orexigenic or anorexigenic hormones. Yet, this did not translate into satiety or food intake effects. A mathematical uncoupling of increases in 'satiety' or 'hunger' hormone concentrations and the satiety effect took place. The observed increased satiety after a breakfast with $10 \%$ of energy from protein compared with a breakfast with $25 \%$ of energy from protein was rather unexpected since previously, high protein meals have been shown to be more satiating than normal protein meals (3). An explanation for this increased satiety may be the increased glucose concentrations in the early postprandial phase after a breakfast with $10 \%$ of energy from protein compared with after a breakfast with $25 \%$ of energy from protein. It has been hypothesized earlier that satiety is more increased with higher glucose concentrations (19). 
A meal higher in protein content induced an increased insulin response as compared with a meal with less protein but the same carbohydrate content (34). Accordingly, increases in insulin concentration were larger after the high than the normal whey-protein breakfast. The larger increase in GLP-1 after a breakfast with $25 \%$ of energy from whey-protein can be explained by the recent finding that whey-protein inhibits dipeptidyl peptidase IV activity, the enzyme breaking down GLP-1, thus prolonging the action of GLP-1 (35). The postprandial ghrelin suppression was increased after a breakfast with $25 \%$ of energy from protein, which is in line with previous studies that showed that insulin can suppress ghrelin and that insulin decreases the duration of the postprandial ghrelin suppression $(36,37)$.

In conclusion, GMP as a whey-fraction reduced energy intake, irrespective of the protein content of the breakfast, coinciding with increased concentrations of certain amino acids (serine, threonine, alanine, alpha-aminobutyric acid, valine and isoleucine). Although between different concentrations of whey-protein significant differences in hormone responses were present, these were not related to effects on satiety ratings or energy intake.

\section{ACKNOWLEDGEMENTS}

This study was funded by the Top Institute Food and Nutrition, The Netherlands.

\section{REFERENCES}

1. Pi-Sunyer FX. Medical hazards of obesity. Ann Intern Med 1993;119:655-60.

2. Seidell JC. Obesity in Europe. Obes Res 1995;3 Suppl 2:89s-93s.

3. Westerterp-Plantenga MS, Luscombe-Marsh N, Lejeune MP, et al. Dietary protein, metabolism, and bodyweight regulation: dose-response effects. Int J Obes (Lond) 2006;30 Suppl 3:S16-23.

4. Lejeune MP, Kovacs EM, Westerterp-Plantenga MS. Additional protein intake limits weight regain after weight loss in humans. Br J Nutr 2005;93:281-9.

5. Skov AR, Toubro S, Ronn B, Holm L, Astrup A. Randomized trial on protein vs carbohydrate in ad libitum fat reduced diet for the treatment of obesity. Int J Obes Relat Metab Disord 1999;23:528-36.

6. Weigle DS, Breen PA, Matthys CC, et al. A high-protein diet induces sustained reductions in appetite, ad libitum caloric intake, and body weight despite compensatory changes in diurnal plasma leptin and ghrelin concentrations. Am J Clin Nutr 2005;82:41-8.

7. Boirie Y, Dangin M, Gachon P, Vasson MP, Maubois JL, Beaufrere B. Slow and fast dietary proteins differently modulate postprandial protein accretion. Proc Natl Acad Sci U S A 1997;94:14930-5.

8. Dangin M, Boirie Y, Garcia-Rodenas C, et al. The digestion rate of protein is an independent regulating factor of postprandial protein retention. Am J Physiol Endocrinol Metab 2001;280:E340-8.

9. Dangin M, Boirie $\mathrm{Y}$, Guillet $\mathrm{C}$, Beaufrere B. Influence of the protein digestion rate on protein turnover in young and elderly subjects. J Nutr 2002;132:3228S-33S.

10. Hall WL, Millward DJ, Long SJ, Morgan LM. Casein and whey exert different effects on plasma amino acid profiles, gastrointestinal hormone secretion and appetite. Br J Nutr 2003;89:239-48.

11. Morifuji M, Sakai K, Sugiura K. Dietary whey protein modulates liver glycogen level and glycoregulatory enzyme activities in exercise-trained rats. Exp Biol Med (Maywood) 2005;230:23-30.

12. Luhovyy BL, Akhavan T, Anderson GH. Whey proteins in the regulation of food intake and satiety. J Am Coll Nutr 2007;26:704S-12S.

13. Marshall K. Therapeutic applications of whey protein. Altern Med Rev 2004;9:136-56.

14. Brody EP. Biological activities of bovine glycomacropeptide. Br J Nutr 2000;84 Suppl 1:S39-46.

15. Gustafson DR, McMahon DJ, Morrey J, Nan R. Appetite is not influenced by a unique milk peptide: caseinomacropeptide (CMP). Appetite 2001;36:157-63.

16. Pedersen NL, Nagain-Domaine C, Mahe S, Chariot J, Roze C, Tome D. Caseinomacropeptide specifically stimulates exocrine pancreatic secretion in the anesthetized rat. Peptides 2000;21:1527-35. 
17. Yvon M, Beucher S, Guilloteau P, Le Huerou-Luron I, Corring T. Effects of caseinomacropeptide (CMP) on digestion regulation. Reprod Nutr Dev 1994;34:527-37.

18. Spaaij CJ, Pijls LT. New dietary reference intakes in the Netherlands for energy, proteins, fats and digestible carbohydrates. Eur J Clin Nutr 2004;58:191-4.

19. Anderson GH, Tecimer SN, Shah D, Zafar TA. Protein source, quantity, and time of consumption determine the effect of proteins on short-term food intake in young men. J Nutr 2004;134:3011-5. Stunkard AJ, Messick S. The three-factor eating questionnaire to measure dietary restraint, disinhibition and hunger. J Psychosom Res 1985;29:71-83.

21. Westerterp-Plantenga MS, Westerterp KR, Rubbens M, Verwegen CR, Richelet JP, Gardette B. Appetite at "high altitude" [Operation Everest III (Comex-'97)]: a simulated ascent of Mount Everest. J Appl Physiol 1999;87:3919.

Munro HN. Second Boyd Orr Memorial Lecture. Regulation of body protein metabolism in relation to diet. Proc Nutr Soc 1976;35:297-308.

23. Harris JA, Benedict FG. A biometric study of basal metabolism in man. Proc Natl Acad Sci 1918;4:370-373.

24. Westerterp KR, Kester AD. Physical activity in confined conditions as an indicator of free-living physical activity. Obes Res 2003;11:865-8.

25. Adam TC, Westerterp-Plantenga MS. Nutrient-stimulated GLP-1 release in normal-weight men and women. Horm Metab Res 2005;37:111-7.

26. Stubbs RJ, Hughes DA, Johnstone AM, et al. The use of visual analogue scales to assess motivation to eat in human subjects: a review of their reliability and validity with an evaluation of new hand-held computerized systems for temporal tracking of appetite ratings. Br J Nutr 2000;84:405-15.

27. van Eijk HM, Rooyakkers DR, Deutz NE. Rapid routine determination of amino acids in plasma by highperformance liquid chromatography with a 2-3 microns Spherisorb ODS II column. J Chromatogr 1993;620:1438.

28. Senn S. Cross-over trials in Statistics in Medicine: The first '25' years. Statistics in Medicine 2006;25:3430-3442

29. Beucher S, Levenez F, Yvon M, Corring T. Effects of gastric digestive products from casein on CCK release by intestinal cells in rat. Journal of Nutritional Biochemistry 1994;5:578-584.

30. Burton-Freeman BM. Glycomacropeptide (GMP) is not critical to whey-induced satiety, but may have a unique role in energy intake regulation through cholecystokinin (CCK). Physiol Behav 2008;93:379-87.

31. Westerterp-Plantenga MS, Rolland V, Wilson SA, Westerterp KR. Satiety related to $24 \mathrm{~h}$ diet-induced thermogenesis during high protein/carbohydrate vs high fat diets measured in a respiration chamber. Eur J Clin Nutr 1999;53:495-502.

32. Cummings DE, Purnell JQ, Frayo RS, Schmidova K, Wisse BE, Weigle DS. A preprandial rise in plasma ghrelin levels suggests a role in meal initiation in humans. Diabetes 2001;50:1714-9.

33. Mellinkoff SM, Frankland M, Boyle D, Greipel M. Relationship between serum amino acid concentration and fluctuations in appetite. J Appl Physiol 1956;8:535-8.

34. Nuttall FQ, Mooradian AD, Gannon MC, Billington C, Krezowski P. Effect of protein ingestion on the glucose and insulin response to a standardized oral glucose load. Diabetes Care 1984; 7:465-70.

35. Gunnarsson PT, Winzell MS, Deacon CF, et al. Glucose-induced incretin hormone release and inactivation are differently modulated by oral fat and protein in mice. Endocrinology 2006;147:3173-80.

36. Cummings DE, Foster-Schubert KE, Overduin J. Ghrelin and energy balance: focus on current controversies. Curr Drug Targets 2005;6:153-69.

37. Hagemann D, Holst JJ, Gethmann A, Banasch M, Schmidt WE, Meier JJ. Glucagon-like peptide 1 (GLP-1) suppresses ghrelin levels in humans via increased insulin secretion. Regul Pept 2007;143:64-8. 
Chapter 6

\section{Dose-dependent satiating effect of whey relative to casein or soy}

Veldhorst MAB, Nieuwenhuizen AG, Hochstenbach-Waelen A, van Vught JAH, Westerterp KR, Engelen MPKJ, Brummer RJM, Deutz NEP, WesterterpPlantenga MS

Physiol Behav 2009; 96 (4-5): 675-682 


\section{ABSTRACT}

Dietary protein plays a role in body weight regulation, partly because of its effects on appetite. The objective was to compare the effects of high or normal casein-, soy-, or whey-protein breakfasts on appetite, specific hormones, amino acid responses and subsequent energy intake. Twenty-five healthy subjects (mean \pm SEM BMI: $23.9 \pm 0.3 \mathrm{~kg} / \mathrm{m}^{2}$; age: $22 \pm 1$ years) received standardized breakfasts: custards with either casein-, soy, or whey-protein with either 10/55/35 (normal) or 25/55/20 (high) En\% protein/carbohydrate/fat in a randomized, single-blind design. Appetite profile (Visual Analogue Scales) and amino acid concentrations were determined for four hours whereas plasma glucose, insulin, active Glucagon-like Peptide 1 (GLP-1), and active ghrelin concentrations were determined for three hours; the sensitive moment for lunch was determined. Subjects returned for a second set of experiments and received the same breakfasts, ad lib lunch was offered 180 minutes later; energy intake (EI) was assessed. At 10 En\%, whey decreased hunger more than casein or soy $(p<0.05)$, coinciding with higher leucine, lysine, tryptophan, isoleucine, and threonine responses $(p<0.05)$. At $25 \mathrm{En} \%$ there were no differences in appetite ratings. Whey triggered the strongest responses in concentrations of active GLP-1 $(p<0.05)$ and insulin $(p<0.05)$ compared with casein and/or soy. There were no differences in El. In conclusion, differences in appetite ratings between different proteins appeared at a normal concentration; at $10 \mathrm{En \%}$ whey-protein decreased hunger more than casein- or soy-protein. At $25 \mathrm{En} \%$ whey-protein triggered stronger responses in hormone concentrations than casein- or soy-protein. The results suggest that a difference in appetite ratings between types of protein appears when certain amino acids are above and below particular threshold values.

KEYWORDS: $\quad$ appetite ratings, casein, soy, whey, amino acids, insulin, active GLP-1, active ghrelin, threshold 


\section{INTRODUCTION}

Obesity is the result of a positive energy balance, which arises when energy intake exceeds energy expenditure. Since body weight regulation involves several pathways, weight management requires a multi-factorial approach (1). Recent findings suggest that a relatively high protein intake plays a role in weight loss as well as in weight maintenance thereafter, partly through increased postprandial and post-absorptive satiety (1-4). Weigle et al. showed that satiety is of major importance, in an experiment in which a high protein diet reduced ad lib food intake while sustaining satiety at a comfortable level during a 12-week period (4). In the present study we focused on short- term satiety effects, i.e. those induced by a single meal. It has been shown that protein is more satiating than carbohydrates or fat (5), and in previous experiments we found differences in appetite ratings between different concentrations of the same protein type (6-8). It is, however, less clear whether there are differences between different types of protein offered at fixed concentrations.

A limited number of human studies have compared different protein types in terms of their effects on satiety. Although Hall et al. found whey to be more satiating than casein (9), their results could not be replicated by others (10). A study by Bowen et al. found no differences in postprandial responses after a whey, soy, or gluten protein preload (11). Anderson et al. nevertheless showed that whey as well as soy protein, but not egg albumen, suppressed food intake at a meal one hour later (12). A comparison of the effects of beef, chicken, and fish protein revealed that fish protein increased satiety more than the other protein types (13). Lang et al. did not observe significantly different effects of egg albumin, casein, gelatin, soy, pea, and wheat gluten on appetite scores or energy intake (14), and in another experiment, casein, soy, and gelatin protein did have weak but inconsistent effects on satiety and did not affect food intake at dinner (15). Thus, results on the satiating properties of different types of protein have been inconclusive.

We investigated differences in appetite between three different protein types, namely casein, soy, and whey, all offered in two concentrations. The amounts of protein represented the highest recommended protein intake per day in energy balance, i.e. $25 \%$ of energy from protein, or the lowest, normal, protein intake per day, $10 \%$ of energy from protein (16). Casein is considered to be a 'slow' protein, whereas whey protein is a relatively 'fast' protein $(9,17-19)$. Soy is a high quality vegetable protein that is often used in food products. Hence, the proteins offered differed in amino acid composition as well as in kinetics. Active GLP-1 and active ghrelin were measured since previous research showed that GLP-1 may inhibit appetite and reduce food intake in humans $(20,21)$, whereas ghrelin is an orexigenic hormone that has been suggested to be involved in meal initiation (22).

The aim of the present study was to compare the effects of casein, soy, or whey containing breakfasts on appetite ratings, plasma amino acid, glucose, insulin, active Glucagon-like Peptide 1 (GLP-1), and active ghrelin concentrations and subsequent energy intake in two dosages. Since the timing of a test meal plays an important role (12), first the moment in time that may be sensitive to show a possible difference in food intake was determined by assessing appetite ratings and blood parameters for four hours. Accordingly, in a subsequent experiment energy intake was measured at the pre-determined moment in time. 


\section{SUBJECTS AND METHODS}

\section{Subjects}

Thirty healthy male and female volunteers (Body Mass Index $22-30 \mathrm{~kg} / \mathrm{m}^{2}$, age $18-40$ years) were recruited by advertisements in local newspapers and on notice boards at the university. They underwent a screening procedure including medical history taking, measurement of body weight and height and cognitive restrained eating, using a Dutch translation of the Three Factor Eating Questionnaire (TFEQ) $(23,24)$. Twenty-five subjects (11 male, 14 female) were selected on the basis of being in good health, non-smokers, non-vegetarian, not cognitively dietary restraint (TFEQ Factor 1 score $\leq 9$ ), not using medication apart from oral contraceptives and at most moderate alcohol users ( $\leq 10$ alcoholic consumptions per week). Their mean age was $22 \pm 1$ years, and their body weight was $74.4 \pm 1.8 \mathrm{~kg}$ (BMI: $23.9 \pm 0.3 \mathrm{~kg} / \mathrm{m}^{2}$ ). Written informed consent was obtained from these participants and the study protocol was approved by the Medical Ethics Committee of the University Hospital Maastricht.

\section{Study design}

A randomized, single-blind, within-subject experimental study was performed. All subjects came to the university on six occasions, separated by at least one week. On each test day, subjects received a subject-specific standardized breakfast. Appetite ratings and blood parameters were obtained for four hours after breakfast.

The sensitive moment in time to offer lunch was determined by the latest time point after breakfast where there still were statistically significant differences in the changes of concentrations of the orexigenic hormone ghrelin between treatments. After two months, when the sensitive moment in time had been determined, subjects returned to the university on six occasions in a randomized, single-blind design, separated by at least one week. On each test day subjects received a subject-specific standardized breakfast, after which an ad lib lunch was offered at the pre-determined sensitive moment in time.

\section{Breakfast}

Breakfast was offered as a custard with either casein (Calcium Caseinate S, DMV International, Veghel, The Netherlands), soy (Supro ${ }^{\circledR} 590$, The Solae Company, St. Louis, MO, United States of America), or whey (Ultra Whey 90, Volactive Functional Food Products, Orwell, United Kingdom) as a single protein source, with either protein/carbohydrate/fat: 10/55/35 En\% (normal protein) or protein/carbohydrate/fat: $25 / 55 / 20 \mathrm{En} \%$ (high protein). Protein was exchanged with fat; carbohydrate content was kept constant because its effect on protein metabolism (25). All custards had an energy density of $4 \mathrm{~kJ} / \mathrm{g}$. The breakfast contained $20 \%$ of daily energy requirements, calculated as basal metabolic rate (BMR), according to the equations of HarrisBenedict, multiplied by an activity index of 1.75 which is the average value reported for the general population in the Netherlands $(26,27)$. The mean energy content of the breakfast was $2.52 \pm 0.07 \mathrm{MJ}$ and the provided breakfasts were finished within 15 minutes.

The custards were produced by NIZO Food Research bv. (Ede, The Netherlands) and had tapioca starch (Farinex VA50T, AVEBE, Veendam, The Netherlands and Perfectamyl 3108 AVEBE, Veendam, The Netherlands) and sunflower oil (Reddy, NV Vandemoortele, Roosendaal, The Netherlands) respectively as the carbohydrate and fat sources and were citrus-vanilla (Citrus, 
J.B. de lange, Belfeld, The Netherlands; Vanilla, J.B. de lange, Belfeld, The Netherlands) flavored. Extensive product development and use of a taste panel lead to custards not different in color, taste, or viscosity. The amino acid composition of the custards is presented in table 1.

Table 1 Amino acid content of the breakfasts given as a custard with either $10 \%$ or $25 \%$ of energy from casein, soy, or whey protein (g amino acid/100 g custard)

\begin{tabular}{lcccccc}
\hline & casein & soy & whey & casein & soy & whey \\
& $10 \%$ & $10 \%$ & $10 \%$ & $25 \%$ & $25 \%$ & $25 \%$ \\
& & & & & & \\
& & & & & & \\
Glutamic acid $^{\text {a }}$ & & & & & & \\
Aspartic acid $^{b}$ & 0.477 & 0.328 & 0.381 & 0.127 & 0.816 & 0.957 \\
Cysteine $_{\text {Serine }}$ & 0.150 & 0.200 & 0.230 & 0.355 & 0.497 & 0.579 \\
Histidine & 0.009 & 0.022 & 0.055 & 0.021 & 0.054 & 0.139 \\
Glycine & 0.120 & 0.089 & 0.099 & 0.283 & 0.220 & 0.249 \\
Threonine & 0.064 & 0.048 & 0.039 & 0.152 & 0.119 & 0.097 \\
Arginine & 0.040 & 0.071 & 0.035 & 0.094 & 0.177 & 0.088 \\
Alanine & 0.090 & 0.066 & 0.150 & 0.214 & 0.164 & 0.378 \\
Tyrosine & 0.092 & 0.139 & 0.055 & 0.218 & 0.345 & 0.139 \\
Valine & 0.064 & 0.073 & 0.106 & 0.150 & 0.182 & 0.266 \\
Methionine & 0.120 & 0.069 & 0.061 & 0.283 & 0.171 & 0.154 \\
Isoleucine & 0.141 & 0.085 & 0.123 & 0.333 & 0.212 & 0.309 \\
Phenylalanine & 0.064 & 0.022 & 0.048 & 0.152 & 0.056 & 0.121 \\
Tryptophan & 0.112 & 0.089 & 0.141 & 0.265 & 0.222 & 0.355 \\
Leucine & 0.110 & 0.094 & 0.062 & 0.259 & 0.234 & 0.156 \\
Lysine & 0.027 & 0.023 & 0.039 & 0.064 & 0.057 & 0.099 \\
Proline & 0.204 & 0.145 & 0.226 & 0.483 & 0.360 & 0.567 \\
& 0.172 & 0.110 & 0.201 & 0.405 & 0.274 & 0.504 \\
\hline
\end{tabular}

${ }^{\text {a }}$ Glutamic acid = glutamine + glutamate

${ }^{\mathrm{b}}$ Aspartic acid $=$ asparagine

Lunch

According to a normal Dutch lunch consisting of bread and a filling, lunch consisted of Turkish bread (400 g) with egg salad (400 g) with 13/41/46 En\% protein/carbohydrate/fat with an energy density of $11.4 \mathrm{~kJ} / \mathrm{g}$. Beforehand it was tested whether all subjects liked the lunch sufficiently. Subjects were instructed to eat till they were comfortably full.

\section{Study protocol}

The protocol started at $08.00 \mathrm{~h}$ after an overnight fast from $22.00 \mathrm{~h}$. A Venflon catheter was placed in a superficial dorsal vein of the hand for blood sampling. To obtain arterialized venous blood samples the hand was placed in a thermostatically controlled hot box at $60^{\circ} \mathrm{C}$ for 20 minutes before the sampling time. A basal blood sample was taken and appetite ratings were scored. After 5 minutes a second basal blood sample was obtained and breakfast was offered ( $\mathrm{t}=0$ minutes). After the first and the last bite, taste perception was scored. Appetite ratings were completed just before breakfast and at 20,40,60,80,100,120, 180, and 240 minutes after breakfast. Blood samples for urea and amino acid determination were obtained at -5 minutes and subsequently just after the appetite ratings; blood samples for determination of glucose, insulin, and active ghrelin concentrations were obtained before and 40,60, 120, and 180 
minutes after breakfast. In order to be able to observe possible differences at 30 and 90 minutes between meals that were observed previously (28), venous blood samples for determination of active GLP-1 concentration were obtained separately before, and at 30,60,90, 120, and 180 minutes after breakfast by means of a Venflon catheter placed in an antecubital vein (28). Subjects were allowed to drink maximally two glasses of water spread over the morning.

In the second set of experiments, the protocol started after an overnight fast from $22.00 \mathrm{~h}$ at $8.30 \mathrm{~h}$ with scoring appetite ratings. Breakfast was offered ( $\mathrm{t}=0$ minutes) and completed within 15 minutes. Subjects stayed in the laboratory till lunch was offered at the previously determined sensitive moment in time. The laboratory was a large room, and subjects were sitting in such a position that they were not able to see each other or each others meals. Maximally eight subjects were tested at the same time. They were sitting behind each other in a row at least two meter apart, with room dividers in between subjects. Remainders of lunch were collected at the end, when all subjects had finished their lunch. They were not allowed to talk to each other, and background music prevented sound-signals that would indicate finishing meals. Subjects were allowed to drink three glasses of water spread over the entire test period.

\section{Measurements}

\section{Appetite profile}

To determine the appetite profile, hunger, fullness, satiety, and desire to eat were rated on 100 $\mathrm{mm}$ Visual Analogue Scales (VAS), anchored with 'not at all' and 'extremely' during the test day. VAS are often used to measure subjective appetite sensations and the validity and reproducibility has been shown in several studies $(29,30)$. Subjects were instructed to rate themselves by marking the scale at the point that was most appropriate to their feeling at that time. The distance from this point to the left end of the scale was measured in $\mathrm{mm}$; changes from baseline $(\Delta)$ were calculated by subtracting the baseline score ( -5 minutes) from the score at a certain time point.

\section{Taste perception}

Taste perception profiles of the custards were assessed after the first and the last bite of the breakfast using $100 \mathrm{~mm}$ Visual Analogue Scales (VAS), anchored with 'not at all' and 'extremely' on the aspects: pleasantness, sweetness, sourness, saltiness, bitterness, savouriness, crispiness, and creaminess.

\section{Blood parameters}

Blood was distributed into EDTA tubes for glucose, insulin, and active ghrelin measurement. For active GLP-1 measurement blood was collected in EDTA tubes with added dipeptidyl peptidase IV inhibitor. For amino acid and urea determination, blood was collected in lithium heparin tubes. Blood samples were centrifuged at $4^{\circ} \mathrm{C}$ for 10 minutes at $3000 \mathrm{rpm}$. Hydrochloric acid and phenylmethylsulfonyl fluoride were added to plasma for active ghrelin determination. For amino acid analysis, $250 \mu \mathrm{l}$ plasma was deproteinized by mixing it with $20 \mathrm{mg}$ dry sulfosalicylic acid. For analysis of urea, $200 \mu \mathrm{l}$ plasma was deproteinized by mixing it with $20 \mu \mathrm{l}$ of a $500 \mathrm{~g} / \mathrm{l}$ trichloroacetic acid solution. All samples were stored at $-80^{\circ} \mathrm{C}$ until further analysis. Plasma glucose concentrations were determined using the hexokinase method (Glucose HK 125 kit, ABX 
diagnostics, Montpellier, France). Insulin concentrations were measured by RIA (Linco Research Inc., St. Charles, Missouri, USA). Plasma active ghrelin concentrations were measured by ELISA (Linco Research Inc., St. Charles, Missouri, USA). Plasma active GLP-1 samples were analyzed using ELISA (EGLP-35K; Linco Research Inc., St. Charles, Missouri, USA). Plasma concentrations of amino acids were determined with the use of a fully automated HPLC (Pharmacia, Woerden, The Netherlands), after precolumn derivatization with o-phthaldialdehyde (31). Plasma urea was analyzed spectrophotometrically on a COBAS Mira S (Roche Diagnostica, Hoffman-La Roche, Basel, Switzerland).

\section{Energy intake}

The food provided for lunch was weighed before and after eating and energy intake was calculated by multiplying the amount of food consumed with the energy value of the food as indicated by the product labels $(11.4 \mathrm{~kJ} / \mathrm{g})$.

\section{Statistical analysis}

Data are presented as mean changes from baseline \pm standard error to the mean (SEM), unless otherwise indicated (32). The area under the curve (AUC) or area above the curve (AAC) of changes from baseline over time for appetite ratings and glucose, insulin, active GLP-1, active ghrelin, amino acid and urea concentrations was calculated using the trapezoidal method. To determine possible differences between the different types of protein at a concentration of $10 \%$ and $25 \%$ of energy from protein, a repeated measures ANOVA between factors with protein level as factor was carried out. When there was no effect of protein level a repeated measures ANOVA with Fisher's PLSD correction for multiple comparisons within one protein type was carried out. After the second set of experiments, a repeated measures ANOVA between factors with protein level as factor and a repeated measures ANOVA with Fisher's PLSD correction for multiple comparisons was carried out to determine possible differences in energy intake. A pvalue $<0.05$ was regarded as statistically significant. Statistical procedures were performed using StatView 5.0 (SAS Institute Inc., USA, 1998).

\section{RESULTS}

\section{Appetite profile}

Baseline appetite ratings were not different between treatments. The changes in appetite ratings per type of protein did not differ depending on protein level. Within one protein level, namely at $10 \%$ of energy from protein, the AAC of hunger ratings was increased more after a breakfast with whey than after a breakfast with casein $(8643 \pm 814$ mmVAS.h vs. $6099 \pm 1066$ mmVAS.h, $p<0.05$, table 2, figure 1). Hunger suppression was increased more after a breakfast with whey than after a breakfast with casein at 20,40,60,80, 120, and 240 minutes after breakfast ( $p<0.05$ for each time point, figure 1 ) and after a breakfast with whey than after a breakfast with soy at 20 minutes after breakfast ( $p<0.05$, figure 1 ). At the level of $25 \%$ of energy from protein there were no differences in hunger ratings between casein, soy, or whey (figure 1). The other appetite ratings were similar with respect to AUC or AAC (fullness, satiety, desire to eat) (data not shown). 
Table 2 Hunger, glucose, insulin, GLP-1, and ghrelin responses expressed as area above the curve (hunger, ghrelin) or area under the curve (glucose, insulin, GLP-1) after a breakfast given as a custard with either $10 \%$ or $25 \%$ of energy from casein, soy, or whey protein in 25 subjects (men and women)

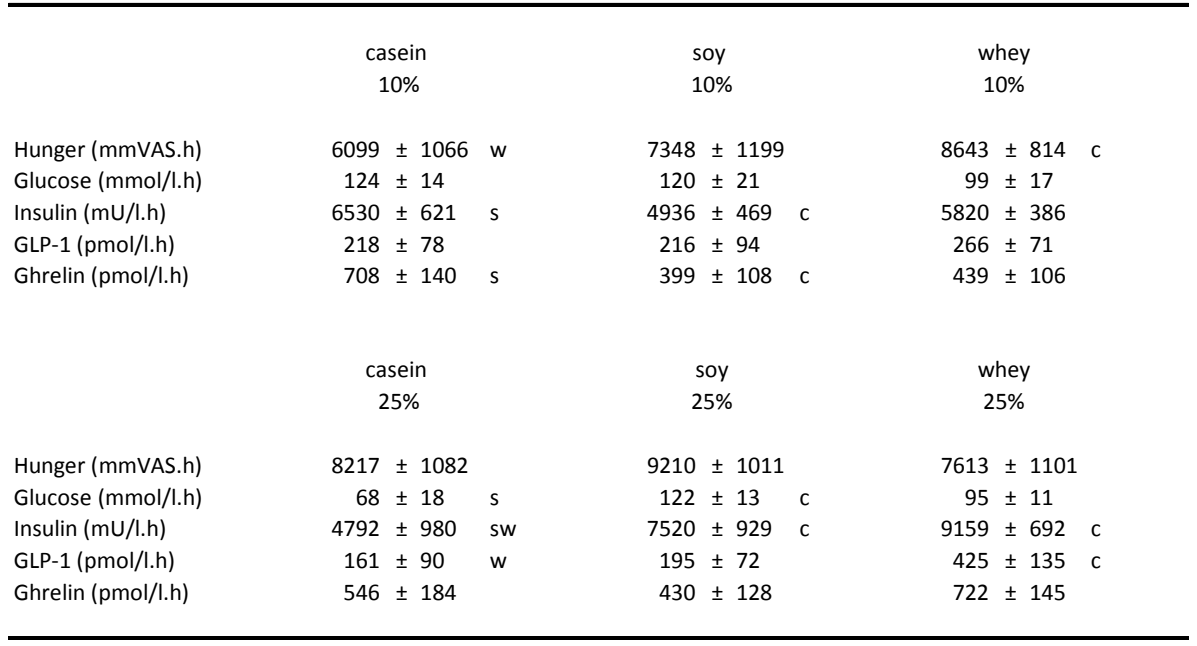

ANOVA repeated measures with Fisher's PLSD correction

Within one protein level, $\mathrm{c}$ indicates a significant difference with casein, $\mathrm{s}$ indicates a significant difference with soy, $\mathrm{w}$ indicates a significant difference with whey

\section{Taste perception}

Pleasantness of taste of the custards with the first bite was sufficient with a mean score of $56 \pm 4$ mmVAS without differences between custards.

\section{Glucose}

Baseline plasma glucose concentrations were not different between treatments. The changes in glucose concentration per type of protein did not differ depending on protein level. Within one protein level there were no differences in changes in glucose concentration between casein, soy, or whey after a breakfast with $10 \%$ of energy from protein, however, after a breakfast with $25 \%$ of energy from protein, glucose concentrations were increased more after a breakfast with soy than after a breakfast with casein $(122+13 \mathrm{mmol} / \mathrm{l} . \mathrm{h}$ vs. $68+18 \mathrm{mmol} / \mathrm{l} . \mathrm{h}, \mathrm{p}<0.05$, table 2$)$.

\section{Insulin}

Baseline plasma insulin concentrations were not different between treatments. The changes in insulin concentration per protein type differed depending on the level of protein. At the level of $10 \%$ of energy from protein, insulin concentrations were increased more after a breakfast with casein than after a breakfast with soy $(6530 \pm 621 \mathrm{mU} / \mathrm{l} . \mathrm{h}$ vs. $4936 \pm 468 \mathrm{mU} / \mathrm{l} . \mathrm{h}, \mathrm{p}<0.05$, table 2 , figure 2) At the level of $25 \%$ of energy from protein, insulin concentrations were increased more after a breakfast with soy or whey than after a breakfast with casein $(7520 \pm 929 \mathrm{mU} / \mathrm{l} . \mathrm{h}$ or 9159 $\pm 692 \mathrm{mU} / \mathrm{l} . \mathrm{h}, \mathrm{vs} .4792 \pm 980 \mathrm{mU} / \mathrm{l} . \mathrm{h}, \mathrm{p}<0.05$ and $\mathrm{p}<0.01$ respectively, table 2 , figure 2 ). 


\section{Active GLP-1}

Baseline plasma active GLP-1 concentrations were not different between treatments. The changes in active GLP-1 concentration per type of protein did not differ depending on protein level. Within one protein level there were no differences in changes in active GLP-1 concentration between casein, soy or whey after a breakfast with $10 \%$ of energy from protein, however, after a breakfast with $25 \%$ of energy from protein, active GLP-1 concentrations were increased more after a breakfast with whey than after a breakfast with casein $(425 \pm 135$ pmol/l.h vs. $161 \pm 90$ pmol/l.h, p<0.05, table 2 ).

\section{Active ghrelin}

Baseline plasma active ghrelin concentrations were not different between treatments. The changes in active ghrelin concentration per type of protein did not differ depending on protein level. Within one protein level, namely $10 \%$ of energy from protein, active ghrelin concentrations were decreased more after a breakfast with casein than after a breakfast with soy (AAC $708 \pm 140$ pmol/l.h vs. $399 \pm 108$ pmol/l.h, $p<0.05$, table 2 , figure 3 ).

A

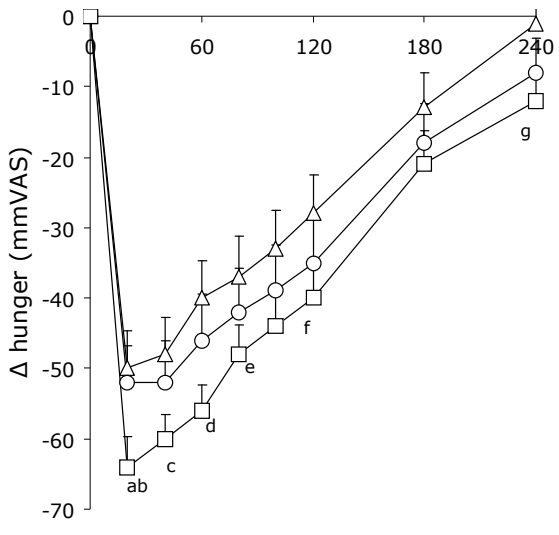

B

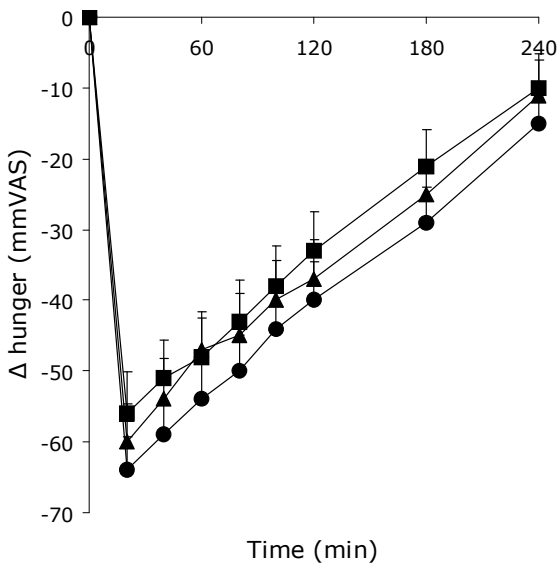

Figure 1 Changes in hunger ratings (mmVAS) after a breakfast offered as a custard with either $10 \%$ (A) or $25 \%$ (B) of energy from casein, soy, or whey protein expressed as delta compared to baseline in 25 subjects (men and women). Values are means + SEM. $\triangle 10 \%$ of energy from casein $\bigcirc 10 \%$ of energy from soy, $\square 10 \%$ of energy from whey, $\boldsymbol{\Delta} 25 \%$ of energy from casein, $25 \%$ of energy from soy, $25 \%$ of energy from whey. ANOVA repeated measures with Fisher's PLSD correction * $\mathrm{p}<0.05,{ }^{* *} \mathrm{p}<0.01$; a whey<casein ${ }^{* *}, \mathrm{~b}$ whey<soy ${ }^{*}, \mathrm{c}$ whey<casein ${ }^{*}, \mathrm{~d}$ whey<casein ${ }^{* *}$, e whey<casein $*, f$ whey<casein ${ }^{*}$, $\mathrm{g}$ whey<casein *; Area Above the Curve hunger $10 \%$ casein<whey * 
A

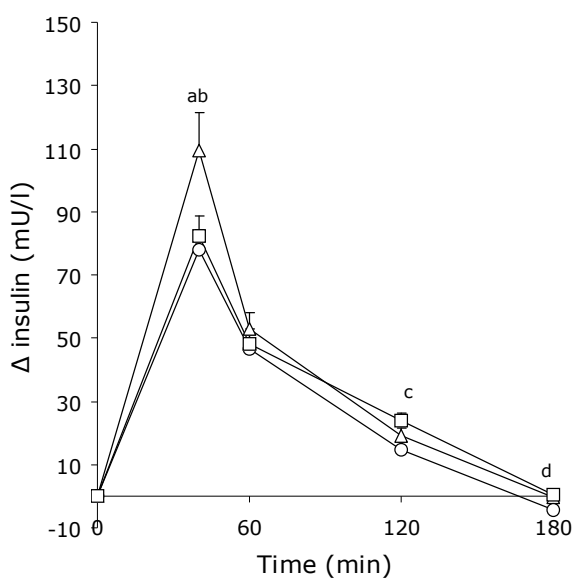

B

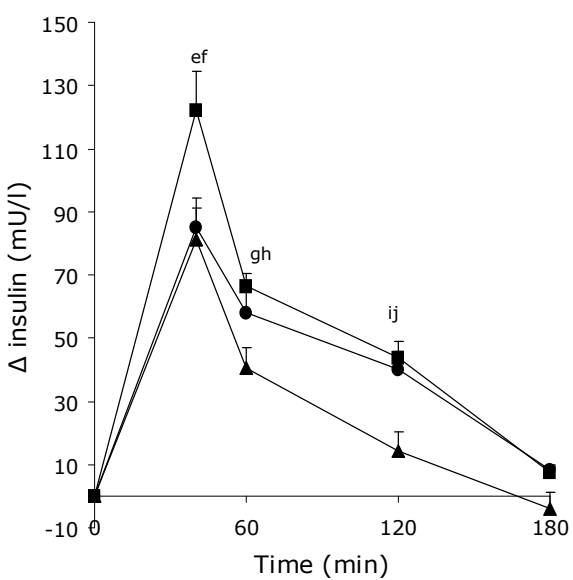

Figure 2 Changes in insulin concentrations ( $\mathrm{mU} / \mathrm{l}$ ) after a breakfast offered as a custard with either $10 \%$ (A) or $25 \%$ (B) of energy from casein, soy, or whey protein expressed as delta compared to baseline in 25 subjects (men and women). Values are means + SEM. $\triangle 10 \%$ of energy from casein $\bigcirc 10 \%$ of energy from soy, $\square 10 \%$ of energy from whey, $\boldsymbol{\Delta} 25 \%$ of energy from casein, $25 \%$ of energy from soy, $25 \%$ of energy from whey. ANOVA repeated measures with Fisher's PLSD correction * $\mathrm{p}<0.05,{ }^{* *} \mathrm{p}<0.01,{ }^{* * *} \mathrm{p}<0.001$; a soy $<$ casein $* *$, b whey $<$ casein $* *$, c soy $<$ whey $* *$, d soy $<$ whey ${ }^{* *}$, e casein $<$ whey $* *$, f soy $<$ whey $* *$, g casein $<$ soy $*$, h casein $<$ whey $* *$, i casein $<$ soy $* * *$, j casein $<$ whey $* * *$; Area Under the Curve insulin soy $10 \%<$ casein $10 \% * *$, Area Under the Curve insulin casein $25 \%<$ soy $25 \% *$, casein $25 \%<$ whey $25 \% * *$

A

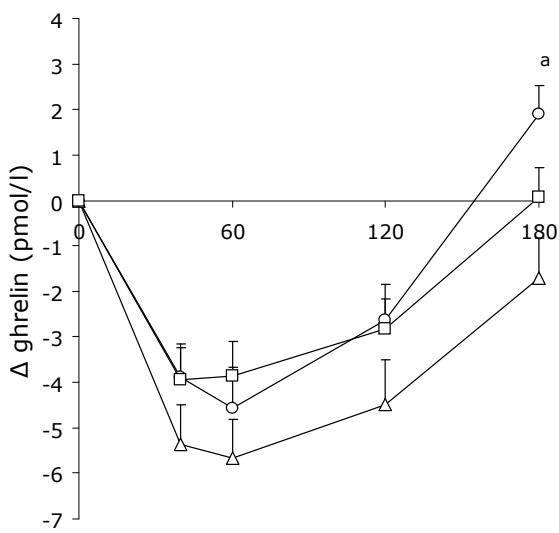

Time (min)
B

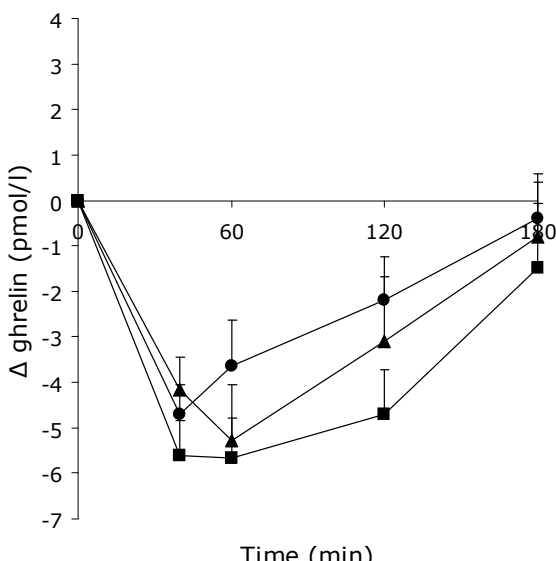

Figure 3 Changes in active ghrelin concentrations (pmol/l) after a breakfast offered as a custard with either $10 \%$ (A) or $25 \%$ (B) of energy from casein, soy, or whey protein expressed as delta compared to baseline in 25 subjects (men and women). Values are means + SEM. $\triangle 10 \%$ of energy from casein $\bigcirc 10 \%$ of energy from soy, $\square 10 \%$ of energy from whey, $\boldsymbol{\Delta} 25 \%$ of energy from casein, $25 \%$ of energy from soy, $25 \%$ of energy from whey. ANOVA repeated measures with Fisher's PLSD correction * $p<0.05,{ }^{* *} p<0.01$; a soy $<$ casein ${ }^{* *}$; Area Above the Curve active ghrelin casein $10 \%<$ soy $10 \% *$ 


\section{Amino acids}

Baseline plasma amino acid concentrations were not different between treatments. The changes in glutamate, asparagine, glycine, threonine, citrulline, arginine, valine, methionine, isoleucine, phenylalanine, tryptophan, leucine, and lysine concentration per type of protein differed depending on protein level. The AUC of the response of the different amino acids after the six different breakfasts is presented in figure 4 ; differences $(p<0.05)$ between treatments are indicated with $\mathrm{C}$ (different from the casein breakfast), $\mathrm{S}$ (different from the soy breakfast), or $\mathrm{W}$ (different from the whey breakfast).

At the level of $10 \%$ of energy from protein the amino acids threonine, alanine, alphaaminobutyric acid, isoleucine, tryptophan, leucine, and lysine were increased more after a breakfast with whey than after a breakfast with casein $(p<0.05$, figure 4$)$. The amino acids threonine, alpha-aminobutyric acid, methionine, isoleucine, tryptophan, leucine, and lysine were increased more after a breakfast with $10 \%$ of energy from whey than after a breakfast with $10 \%$ of energy from soy $(p<0.05$, figure 4$)$.

At the level of $25 \%$ of energy from protein, the amino acids asparagine, threonine, alphaaminobutyric acid, valine, isoleucine, tryptophan, leucine and lysine were increased more after a breakfast with whey than after a breakfast with casein $(p<0.05$, figure 4$)$. The amino acids threonine, alpha-aminobutyric acid, valine, isoleucine, tryptophan, leucine and lysine were increased more after a breakfast with whey than after a breakfast with soy $(p<0.05$, figure 4$)$.

\section{Energy intake}

Based on the significant differences in concentrations of the orexigenic hormone active ghrelin at 180 minutes, the ad lib lunch was offered at 180 minutes after breakfast.

At the level of $10 \%$ of energy from protein, energy intake at lunch was $3133 \pm 226 \mathrm{~kJ}, 3098 \pm 286$ $\mathrm{kJ}$ and $2879 \pm 239 \mathrm{~kJ}$ after the breakfast with casein, soy, or whey respectively (ns). At the level of $25 \%$ of energy from protein, energy intake at lunch was $3080 \pm 229 \mathrm{~kJ}, 3212 \pm 280 \mathrm{~kJ}$ and 2876 $\pm 243 \mathrm{~kJ}$ after the breakfast with casein, soy, or whey, respectively (ns). 


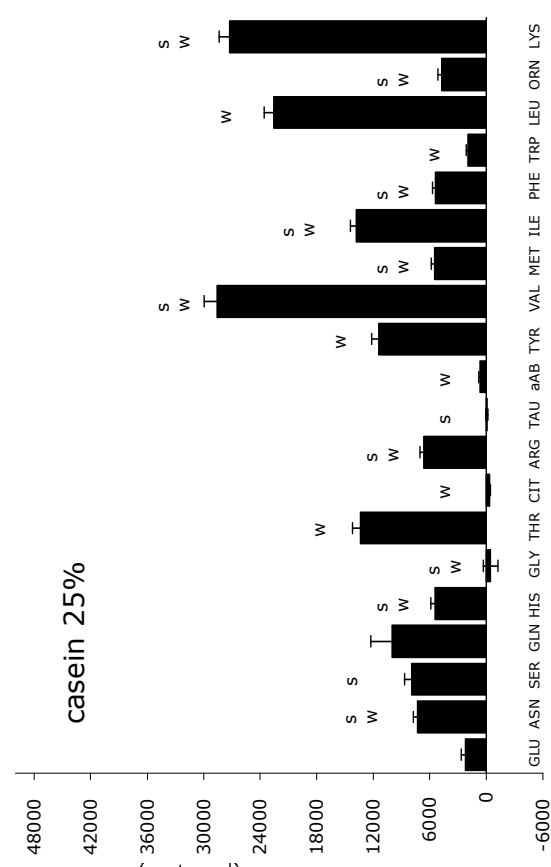

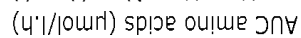

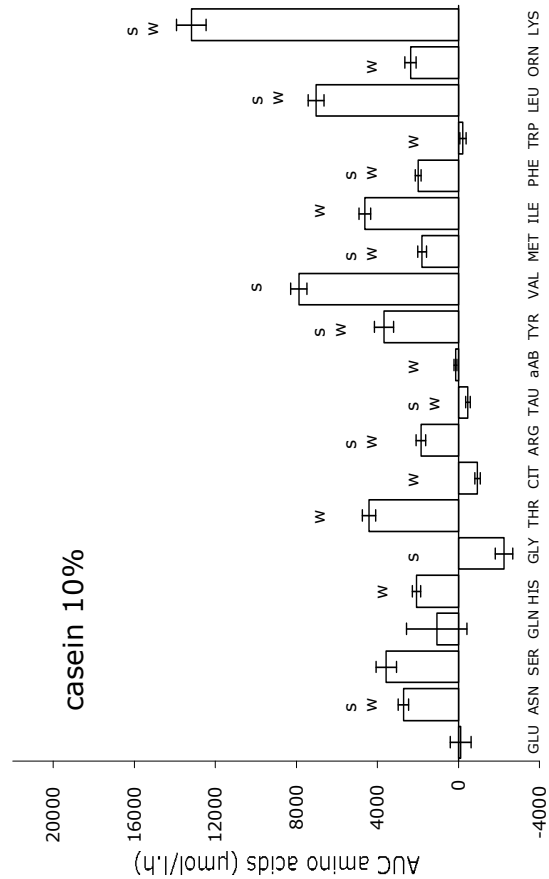

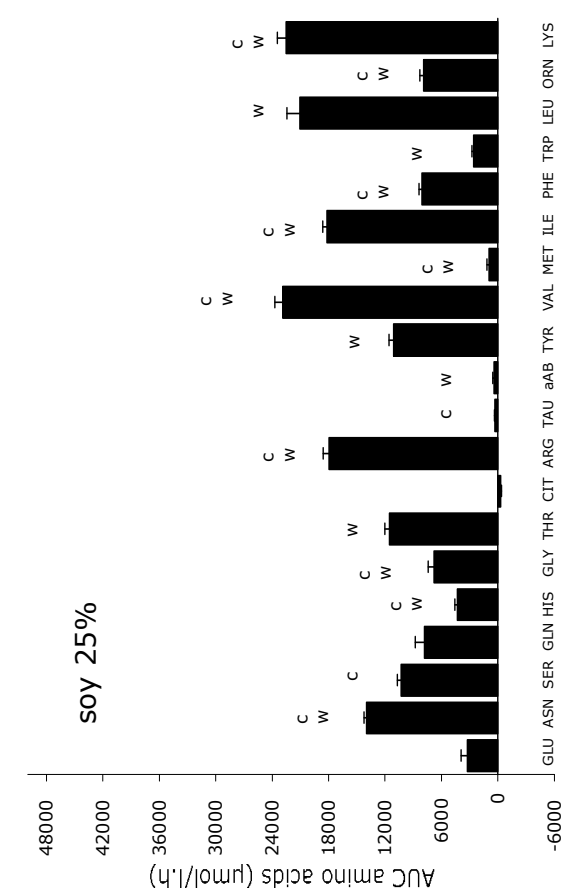

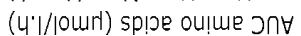

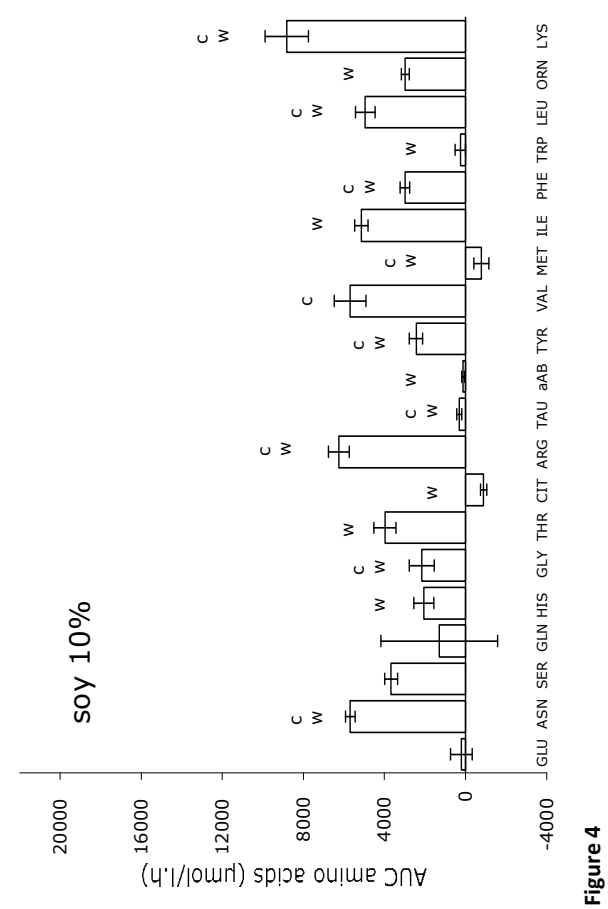




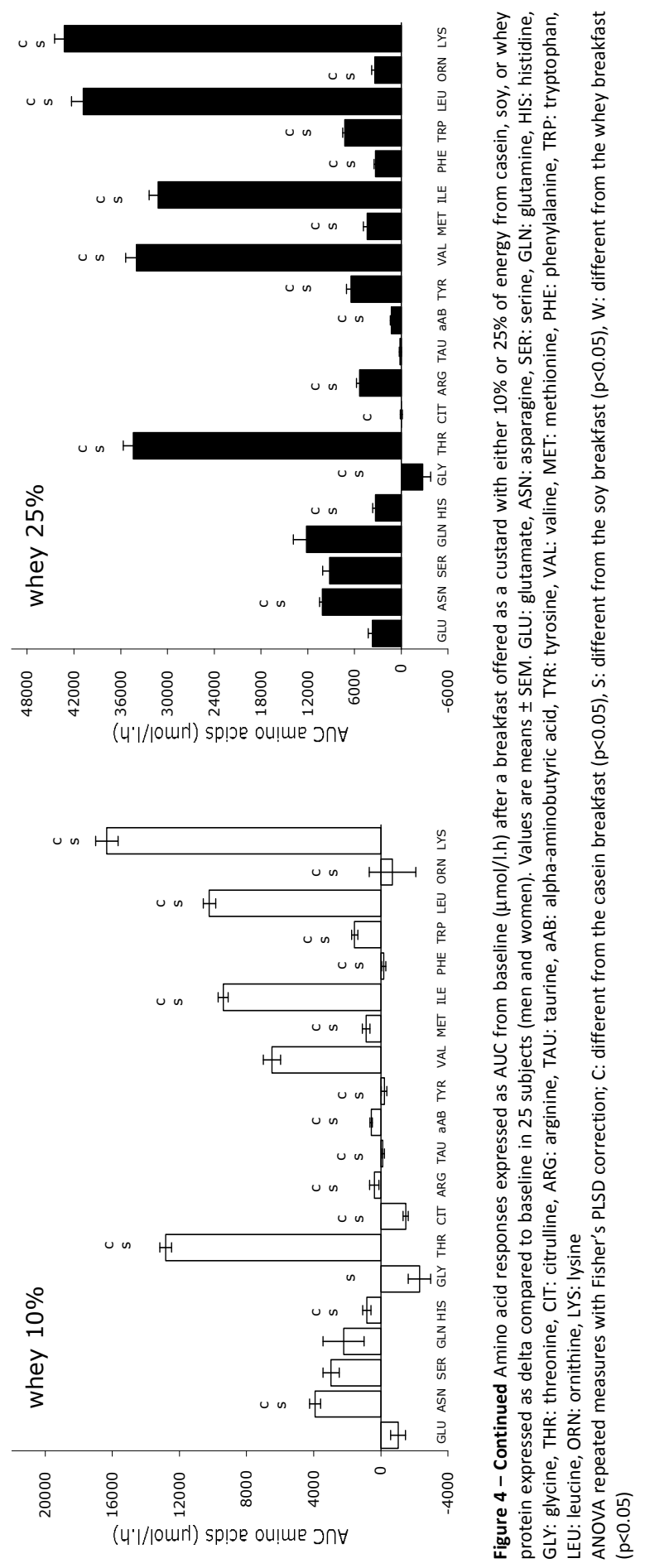




\section{DISCUSSION}

Based upon the appetite ratings, a breakfast with whey reduced hunger more than a breakfast with casein, and at short term also than soy, at the level of $10 \%$ of energy from protein, however, this did not affect subsequent energy intake at lunch. At the level of $25 \%$ of energy from protein, the breakfast with whey triggered the strongest response in insulin and active GLP-1, however, there were no differences in appetite ratings or energy intake at lunch.

The citrus-vanilla flavored custards were similar to custards widely available and often consumed in the Netherlands. It is therefore unlikely that unfamiliarity with the breakfasts influenced satiety responses. To avoid any specific sensory effect of the iso-energetic custards, food technology was involved to optimize taste and hedonic value of the breakfasts. The custards were citrus-vanilla flavoured and after being tested by a professional taste panel of NIZO Food Research, taste perception and hedonic values again were evaluated by the subjects and were excluded to affect appetite profile ratings differently.

The relatively stronger hunger suppression after a breakfast with $10 \%$ of energy from whey, compared with a breakfast with casein or soy, coincided with a greater increase in responses of leucine, lysine, tryptophan, isoleucine, and threonine; amino acids which may be involved in the satiety response. Leucine and isoleucine are two of the three branched-chain amino acids that regulate protein synthesis and degradation, as well as insulin secretion and synthesis (33). The concomitant high energy costs of these processes may be related to satiety $(5,34)$. Tryptophan has been suggested to be involved in satiety via brain serotonin; serotonin is synthesized from tryptophan and is an important regulator of appetite, macronutrient preference, and mood (35). The results of the present study suggest that tryptophan may indeed be involved in the satiety process. Lysine has previously been shown to produce a moderate decrease in food intake in sheep (36); excess levels of threonine added to a low protein diet resulted in a reduced weight gain in rats (37). The mechanisms via which these amino acids may influence satiety are not clear however and need to be further established.

The moment at which lunch was offered was based upon the latest moment in time when there were significant differences in ghrelin concentrations between treatments. Ghrelin has been suggested to play a physiological role in meal initiation in humans (22). Differences in ghrelin concentrations may therefore result in differences in energy intake. Although there were differences in appetite ratings between the different types of protein at the level of $10 \%$ of energy from protein, there were no significant differences in energy intake. Apparently in this experiment the differences in appetite ratings were not large enough to induce effects on energy intake.

With respect to the proteins offered in a concentration with $25 \%$ of energy there were no differences in appetite ratings. Nevertheless there were significant differences in hormone responses between the breakfasts with $25 \%$ of energy from protein; after a breakfast with whey, increases in insulin and active GLP-1 were larger than after a breakfast with casein and/or soy. Previously it has been shown that casein coagulates in the stomach which delays gastric emptying $(17,18,38)$, this resulted in slower and less pronounced physiological responses compared with soy and whey. The relatively larger insulin responses after the high whey breakfast is in accordance with the findings of Frid and others, reporting an insulinotrophic 
effect of whey which partly may be explained by the involvement of certain amino acids that have insulinogenic properties $(39,40)$. The larger increase in active GLP-1 concentrations after a breakfast with whey can be explained by the finding that whey inhibits dipeptidyl peptidase IV activity, the enzyme involved in the breakdown of active GLP-1, thus prolonging the action of active GLP-1 (41). Active GLP-1 enhances satiety and is an incretin hormone whereas insulin has been reported to inhibit active GLP-1 secretion, probably as a negative feedback loop $(20,21$, 42). Although insulin and active GLP-1 are considered as 'satiety' hormones, there was no larger increase in hunger ratings after a breakfast with $25 \%$ of energy from whey than after the other breakfasts. Here, a mathematical uncoupling of a satiating effect and increases in 'satiety' hormone concentrations takes place.

Since there were differences in appetite ratings between types of protein at the level of $10 \%$ but not at the level of $25 \%$ of energy, it seems that the concentrations of certain amino acids need to be above a particular threshold to promote a relatively stronger hunger suppression or greater satiety. The results suggest that certain proteins will reach these threshold concentrations earlier than other types of protein. After a breakfast with whey, sufficiently increased amino acid concentrations were reached at the level of $10 \%$ of energy, whereas concentrations were lower after a breakfast with casein or soy. Hence, discriminating between types of protein is probably not sensitive anymore at a higher level of protein, since the amino acid responses of all breakfasts were above the threshold.

This is the first study that investigated acute differences in appetite ratings between types of protein in concentrations within the normal range in realistic mixed meals. The relatively high amount of protein ( $\geq 50 \mathrm{En} \%$ ) may have caused the lack of differences in satiety between different types of protein when comparing appetite after either a casein, whey, or carbohydrate preload or when comparing ad lib food intake after whey, soy, or gluten protein $(10,11)$. It may not be possible to distinguish satiating properties of different types of protein anymore when the concentration of amino acids is above a threshold level. In the present study the protein part of the breakfast consisted exclusively of the protein type to be investigated whereas in previous comparisons of the satiating capacities of egg albumin, casein, gelatin, soy, pea, and wheat gluten protein only 60 to $70 \%$ of the protein part was manipulated. This may have lead to diminished results and consequently the absence of significant differences in appetite ratings between the different protein types $(14,15)$. Timing plays an important role in studying the effect of protein on food intake. An amount of $0.65 \mathrm{~g} / \mathrm{kg}$ body weight of whey, soy, or egg albumen protein did induce significant differences in food intake one hour after the preload compared with water as control, however, this is a rather irrelevant moment in time for a next meal in a normal, free-living situation (12). Hall et al. observed a reduced desire to eat after a whey preload of $1.7 \mathrm{MJ}$ with $48 \mathrm{~g}$ protein compared with a similar casein preload (9). However, 90 minutes after the preload subjects already got a standard lunch with fixed energy intake. The reduced desire to eat was observed between 90 and 180 minutes; conclusions about the solely effect of the two preloads can hardly be drawn. Moreover, the conclusions by Hall et al. could not be confirmed in a similar study from Bowen and colleagues $(10,11)$.

This study provides new information for the development weight-loss diets. Whey-protein can be used, already with an amount of $10 \mathrm{En} \%$, in a diet to help people comply to a diet. When people feel less hungry and desire to eat is suppressed, it is easier for them to comply to a diet because they really feel an effect of the diet. Although there were no short term differences in 
energy intake between casein, soy and whey in the present study, people may comply better to a high protein diet with whey and eventually eat less and lose weight.

In conclusion, hunger was decreased more after a breakfast with whey than after a breakfast with casein or soy in a concentration of $10 \%$ of energy from protein, which coincided with increased concentrations of the amino acids leucine, lysine, tryptophan, isoleucine, and threonine. Although there were no differences in appetite ratings between casein, soy, or whey at a level of $25 \%$ of energy from protein, the breakfast with whey triggered stronger responses in hormone concentrations than the breakfasts with casein or soy. The results suggest that a difference in appetite ratings between different types of protein may only appear when certain amino acids are above and below particular thresholds.

\section{REFERENCES}

1. Westerterp-Plantenga MS, Luscombe-Marsh N, Lejeune MP, et al. Dietary protein, metabolism, and bodyweight regulation: dose-response effects. Int J Obes (Lond) 2006;30 Suppl 3:S16-23.

2. Skov AR, Toubro S, Ronn B, Holm L, Astrup A. Randomized trial on protein vs carbohydrate in ad libitum fat reduced diet for the treatment of obesity. Int J Obes Relat Metab Disord 1999;23:528-36.

3. Lejeune MP, Kovacs EM, Westerterp-Plantenga MS. Additional protein intake limits weight regain after weight loss in humans. Br J Nutr 2005;93:281-9.

4. Weigle DS, Breen PA, Matthys CC, et al. A high-protein diet induces sustained reductions in appetite, ad libitum caloric intake, and body weight despite compensatory changes in diurnal plasma leptin and ghrelin concentrations. Am J Clin Nutr 2005;82:41-8.

5. Westerterp-Plantenga MS, Rolland V, Wilson SA, Westerterp KR. Satiety related to $24 \mathrm{~h}$ diet-induced thermogenesis during high protein/carbohydrate vs high fat diets measured in a respiration chamber. Eur J Clin Nutr 1999;53:495-502.

6. Veldhorst MA, Nieuwenhuizen AG, Hochstenbach-Waelen A, et al. Comparison of the effects of a high- and normal-casein breakfast on satiety, 'satiety' hormones, plasma amino acids and subsequent energy intake. $\mathrm{Br} J$ Nutr 2009;101:295-303.

7. Veldhorst MA, Nieuwenhuizen AG, Hochstenbach-Waelen A, et al. Effects of complete whey-protein breakfasts versus whey without GMP-breakfasts on energy intake and satiety. Appetite 2009;52:388-95.

8. Veldhorst MA, Nieuwenhuizen AG, Hochstenbach-Waelen A, et al. Effects of high and normal soyprotein breakfasts on satiety and subsequent energy intake, including amino acid and 'satiety' hormone responses. Eur J Nutr 2009;48:92-100.

9. Hall WL, Millward DJ, Long SJ, Morgan LM. Casein and whey exert different effects on plasma amino acid profiles, gastrointestinal hormone secretion and appetite. Br J Nutr 2003;89:239-48.

10. Bowen J, Noakes M, Trenerry C, Clifton PM. Energy intake, ghrelin, and cholecystokinin after different carbohydrate and protein preloads in overweight men. J Clin Endocrinol Metab 2006;91:1477-83.

11. Bowen J, Noakes M, Clifton PM. Appetite regulatory hormone responses to various dietary proteins differ by body mass index status despite similar reductions in ad libitum energy intake. J Clin Endocrinol Metab 2006;91:2913-9.

12. Anderson GH, Tecimer SN, Shah D, Zafar TA. Protein source, quantity, and time of consumption determine the effect of proteins on short-term food intake in young men. J Nutr 2004;134:3011-5.

13. Uhe AM, Collier GR, O'Dea K. A comparison of the effects of beef, chicken and fish protein on satiety and amino acid profiles in lean male subjects. J Nutr 1992;122:467-72.

14. Lang V, Bellisle F, Oppert JM, et al. Satiating effect of proteins in healthy subjects: a comparison of egg albumin, casein, gelatin, soy protein, pea protein, and wheat gluten. Am J Clin Nutr 1998;67:1197-204.

15. Lang V, Bellisle F, Alamowitch $\mathrm{C}$, et al. Varying the protein source in mixed meal modifies glucose, insulin and glucagon kinetics in healthy men, has weak effects on subjective satiety and fails to affect food intake. Eur J Clin Nutr 1999;53:959-65.

16. Spaaij CJ, Pijls LT. New dietary reference intakes in the Netherlands for energy, proteins, fats and digestible carbohydrates. Eur J Clin Nutr 2004;58:191-4.

17. Boirie $Y$, Dangin M, Gachon P, Vasson MP, Maubois JL, Beaufrere B. Slow and fast dietary proteins differently modulate postprandial protein accretion. Proc Natl Acad Sci U S A 1997;94:14930-5.

18. Dangin $\mathrm{M}$, Boirie $\mathrm{Y}$, Garcia-Rodenas $\mathrm{C}$, et al. The digestion rate of protein is an independent regulating factor of postprandial protein retention. Am J Physiol Endocrinol Metab 2001;280:E340-8. 
19.

20.

21.

22.

23.

24.

25.

26.

27.

28.

29.

30.

31.

32.

33.

34.

35.

36.

37.

38.

39.

40.

41.

42.

Dangin M, Boirie Y, Guillet C, Beaufrere B. Influence of the protein digestion rate on protein turnover in young and elderly subjects. J Nutr 2002;132:3228S-33S.

Flint A, Raben A, Astrup A, Holst JJ. Glucagon-like peptide 1 promotes satiety and suppresses energy intake in humans. J Clin Invest 1998;101:515-20.

Holst JJ. Glucagon-like Peptide 1 (GLP-1): An Intestinal Hormone, Signalling Nutritional Abundance, with an Unusual Therapeutic Potential. Trends Endocrinol Metab 1999;10:229-235.

Cummings DE, Purnell JQ, Frayo RS, Schmidova K, Wisse BE, Weigle DS. A preprandial rise in plasma ghrelin levels suggests a role in meal initiation in humans. Diabetes 2001;50:1714-9.

Stunkard AJ, Messick S. The three-factor eating questionnaire to measure dietary restraint, disinhibition and hunger. J Psychosom Res 1985;29:71-83.

Westerterp-Plantenga MS, Westerterp KR, Rubbens M, Verwegen CR, Richelet JP, Gardette B. Appetite at "high altitude" [Operation Everest III (Comex-'97)]: a simulated ascent of Mount Everest. J Appl Physiol 1999;87:3919.

Munro HN. Second Boyd Orr Memorial Lecture. Regulation of body protein metabolism in relation to diet. Proc Nutr Soc 1976;35:297-308.

Harris JA, Benedict FG. A biometric study of basal metabolism in man. Proc Natl Acad Sci 1918;4:370-373.

Westerterp KR, Kester AD. Physical activity in confined conditions as an indicator of free-living physical activity. Obes Res 2003;11:865-8.

Adam TC, Westerterp-Plantenga MS. Nutrient-stimulated GLP-1 release in normal-weight men and women Horm Metab Res 2005;37:111-7.

Flint A, Raben A, Blundell JE, Astrup A. Reproducibility, power and validity of visual analogue scales in assessment of appetite sensations in single test meal studies. Int J Obes Relat Metab Disord 2000;24:38-48.

Rogers PJ, Blundell JE. Separating the actions of sweetness and calories: effects of saccharin and carbohydrates on hunger and food intake in human subjects. Physiol Behav 1989;45:1093-9.

van Eijk HM, Rooyakkers DR, Deutz NE. Rapid routine determination of amino acids in plasma by highperformance liquid chromatography with a 2-3 microns Spherisorb ODS II column. J Chromatogr 1993;620:1438.

Senn S. Cross-over trials in Statistics in Medicine: The first '25' years. Statistics in Medicine 2006;25:3430-3442.

ynch CJ, Patson BJ, Anthony J, Vaval A, Jefferson LS, Vary TC. Leucine is a direct-acting nutrient signal that regulates protein synthesis in adipose tissue. Am J Physiol Endocrinol Metab 2002;283:E503-13.

Layman DK, Walker DA. Potential importance of leucine in treatment of obesity and the metabolic syndrome. $J$ Nutr 2006;136:319S-23S.

Beulens JW, Bindels JG, de Graaf C, Alles MS, Wouters-Wesseling W. Alpha-lactalbumin combined with a regular diet increases plasma Trp-LNAA ratio. Physiol Behav 2004;81:585-93.

Baile CA, Martin FH. Hormones and amino acids as possible factors in the control of hunger and satiety in sheep. J Dairy Sci 1971;54:897-905.

Muramatsu K, Odagiri H, Morishita S, Takeuchi H. Effect of excess levels of individual amino acids on growth of rats fed casein diets. J Nutr 1971;101:1117-25

Mahe S, Roos N, Benamouzig R, et al. Gastrojejunal kinetics and the digestion of [15N]beta-lactoglobulin and casein in humans: the influence of the nature and quantity of the protein. Am J Clin Nutr 1996;63:546-52.

Frid AH, Nilsson M, Holst JJ, Bjorck IM. Effect of whey on blood glucose and insulin responses to composite breakfast and lunch meals in type 2 diabetic subjects. Am J Clin Nutr 2005;82:69-75.

Nilsson M, Stenberg M, Frid AH, Holst JJ, Bjorck IM. Glycemia and insulinemia in healthy subjects after lactoseequivalent meals of milk and other food proteins: the role of plasma amino acids and incretins. Am J Clin Nutr 2004;80:1246-53.

Gunnarsson PT, Winzell MS, Deacon CF, et al. Glucose-induced incretin hormone release and inactivation are differently modulated by oral fat and protein in mice. Endocrinology 2006;147:3173-80. Kieffer TJ, Habener JF. The glucagon-like peptides. Endocr Rev 1999;20:876-913. 

Chapter 7

\section{A breakfast with alpha-lactalbumin, gelatin, or gelatin+TRP lowers energy intake at lunch compared with a breakfast with casein, soy, whey, or whey-GMP}

Veldhorst MAB, Nieuwenhuizen AG, Hochstenbach-Waelen A, Westerterp KR, Engelen MPKJ, Brummer RJM, Deutz NEP, Westerterp-Plantenga MS

Clin Nutr 2009; 28 (2): 147-155 


\section{ABSTRACT}

Background\&aims: Dietary protein plays a role in body weight regulation, partly due to its effects on satiety. The objective was to compare the effects of casein-, soy-, whey-, whey without glycomacropeptide (GMP)-, alpha-lactalbumin-, gelatin-, or gelatin with tryptophan (TRP)- protein breakfasts at two concentrations on subsequent satiety and energy intake (EI).

Methods: Twenty-four healthy subjects (mean \pm SEM BMI: $24.8 \pm 0.5 \mathrm{~kg} / \mathrm{m}^{2}$; age: $25 \pm 2$ years) received a breakfast; a custard with casein, soy, whey, whey-GMP, alpha-lactalbumin, gelatin, or gelatin+TRP as protein source with either 10/55/35 (normal) or 25/55/20 (high) En\% protein/carbohydrate/fat in a randomized, single-blind design. At the precedingly determined time-point for lunch, 180 minutes, subjects were offered an ad lib lunch. Appetite profile (Visual Analogue Scales, VAS) and El were determined.

Results: Both at the level of $10 \mathrm{En} \%$ and $25 \mathrm{En \%}$ from protein, El at lunch was 20\% lower after an alpha-lactalbumin or gelatin(+TRP) breakfast $(2.5 \pm 0.2 \mathrm{MJ})$ compared with after a casein, soy, or whey-GMP breakfast $(3.2 \pm 0.3 \mathrm{MJ}, \mathrm{p}<0.05)$. Appetite ratings at 180 minutes differed 15 $25 \mathrm{~mm}(\sim 40 \%, p<0.05)$ between types of protein.

Differences in El were a function of differences in appetite ratings $\left(R^{2}=0.4, p<0.001\right)$.

Conclusions: Different proteins (alpha-lactalbumin, gelatin, gelatin+TRP) that are $\sim 40 \%$ more satiating than other proteins (casein, soy, whey, whey-GMP) induce a related $\sim 20 \%$ reduction of subsequent energy intake.

KEYWORDS: $\quad$ energy intake, satiety, dietary proteins, timing, amino acids 


\section{INTRODUCTION}

Overweight and obesity are the result of a positive energy balance and since body weight regulation involves several pathways, weight management requires a multi-factorial approach (1). A relatively elevated protein diet implies this multi-factorial approach through increased postprandial and post-absorptive satiety, increased thermogenesis, preservation of fat-free body mass, and lower energy-efficiency compared with control diets $(1,2)$. Although protein has been shown to increase satiety, the subsequent effect, i.e. spontaneously reduced food intake, has been shown in very few studies. Weigle et al. however showed that a high protein diet reduced ad lib food intake while sustaining satiety at a comfortable level (2). In the present study we focused on short-term satiety effects, i.e. effects on satiety and subsequent food intake induced by a single meal. A protein that is more satiating and decreases energy intake could potentially be used as part of a weight-loss diet to help people to comply to their diet and actually lose weight.

Data on different types of protein affecting food intake are inconclusive. Although Hall and colleagues found whey to be more satiating than casein (3), Bowen et al., did not find differences in energy intake after casein or whey preloads $(4,5)$. A study by Lang et al. found no different effects of egg albumin, casein, gelatin, soy, pea, and wheat gluten on energy intake, and in another experiment, there also were no differences in post-lunch energy intake after a casein-, soy-, or gelatin-lunch $(6,7)$. Anderson et al. found that whey and soy protein decreased food intake more than egg protein, one hour after a preload (8).

In the present study we assessed a possible effect on energy intake by type of protein, offered in two concentrations. The amounts of protein chosen represented the highest recommended protein intake per day (25 En\%) versus a normal protein intake per day (10 En\%) (9). Casein was selected as one of the protein types as being a 'slow' protein whereas whey is considered as relatively 'fast' protein, inducing satiety quickly $(3,10-12)$. Both whey and whey where glycomacropeptide (GMP) was removed were selected since GMP has been suggested to contribute to the satiating effects of whey $(13,14)$. Soy was studied because it is a high quality vegetable protein often used in food products. Alpha-lactalbumin contains high levels of tryptophan (TRP) and relatively low levels of large neutral amino acids (LNAA); whether the increased TRP/LNAA ratio in the plasma (15) would also increase brain serotonin production and influence food intake remains to be elucidated. The oxidation of gelatin is calculated to be highly inefficient causing a high thermogenesis, which could affect satiety. In addition, gelatin was also offered with added TRP, in order to discriminate whether a possible difference between gelatin and alpha-lactalbumin was due to the TRP content.

Timing has been shown to play an important role when studying the effect of protein on food intake (8), therefore it is of importance to measure energy intake at a sensitive and relevant moment in time. In a preceding experiment, the moment in time that may be sensitive to show a possible difference in food intake was determined by assessing satiety ratings and blood parameters for four hours after consumption of the same protein-meals as in the current study. Three hours after breakfast significant differences in the orexigenic hormone ghrelin were present, so this was chosen as the moment in time to offer lunch (16-18). 
The objective of this study was to evaluate the effect of casein, soy, whey, whey-GMP, alphalactalbumin, gelatin, or gelatin with added TRP in two concentrations of protein in the breakfast on energy intake at lunch, which was offered three hours after breakfast.

\section{SUBJECTS AND METHODS}

\section{Subjects}

Thirty healthy male and female volunteers (Body Mass Index $22-32 \mathrm{~kg} / \mathrm{m}^{2}$, age $18-45$ years) were recruited by advertisements in local newspapers and on notice boards at the university. They underwent a screening procedure including medical history taking, measurement of body weight and height and cognitively restrained eating, using a Dutch translation of the Three Factor Eating Questionnaire (TFEQ) $(19,20)$. Twenty-four subjects (10 male, 14 female) were selected on the basis of being in good health, non-smokers, non-vegetarian, not cognitively dietary restraint (TFEQ Factor $1 \leq 9$ ), not using medication apart from oral contraceptives and at most moderate alcohol users ( $\leq 10$ alcoholic consumptions per week). Their mean age was $25 \pm 2$ years, and their body weight was $72.8 \pm 2.2 \mathrm{~kg}$ (BMI: $24.8 \pm 0.5 \mathrm{~kg} / \mathrm{m}^{2}$ ). Written informed consent was obtained from all participants and the study protocol was approved by the Medical Ethics Committee of the University Hospital Maastricht.

\section{Study design}

A randomized, single-blind, within-subject experimental study was performed. All subjects came to the university on 14 occasions, separated by at least three days. On each test day subjects received a subject-specific standardized breakfast. Three hours after breakfast an ad lib lunch was offered; appetite ratings were obtained until six hours after breakfast.

\section{Preceding experiments}

In preceding experiments (16-18), the sensitive moment in time to offer lunch was determined using the same breakfasts. In those studies the protocol started at $08.00 \mathrm{~h}$ after an overnight fast from 22.00h. A Venflon catheter was placed in a superficial dorsal vein of the hand for blood sampling. To obtain arterialized venous blood samples the hand was placed in a thermostatically controlled hot box at $60^{\circ} \mathrm{C}$ for 20 minutes before the sampling time. A basal blood sample was taken and appetite ratings were scored. After 5 minutes a second basal blood sample was obtained and breakfast was offered ( $t=0$ minutes). After the first and the last bite, taste perception was scored. Appetite ratings were completed just before breakfast and at 20, 40,60, $80,100,120,180$, and 240 minutes after breakfast. Blood samples for urea and amino acid determination were obtained at -5 minutes and subsequently just after the appetite ratings; blood samples for determination of glucose, insulin, and ghrelin concentrations were obtained before and 40, 60, 120, and 180 minutes after breakfast. Venous blood samples for determination of GLP-1 concentration were obtained separately before, and at 30, 60, 90, 120, and 180 minutes after breakfast by means of a Venflon catheter placed in an antecubital vein (21). Subjects were allowed to drink maximally two glasses of water spread over the morning. Details on analyses and results were described previously (16-18). In summary, these experiments revealed that differences in concentrations of insulin, GLP-1 or certain amino acids, 
depending on the type of protein used, coincided with the differences in satiety among different proteins served at breakfast. However, the effects of these hormones and metabolites were different for each protein.

\section{Breakfast}

Breakfast was offered as a custard, with either casein (Calcium Caseinate S, DMV International, Veghel, The Netherlands), soy (Supro ${ }^{\circledR} 590$, The Solae Company, St. Louis, MO, United States of America), whey (Ultra Whey 90, Volactive Functional Food Products, Orwell, United Kingdom), whey-GMP (WPC 80, DMV International, Veghel, The Netherlands), alpha-lactalbumin (BioPURE Alphalactalbumin ${ }^{\mathrm{TM}}$, Davisco Foods International Inc., Eden Prairie, United States of America), gelatin (Solugel LMC/3, PB Gelatins GmbH, Nienburg/Weser, Germany), or gelatin+TRP (Solugel LMC/3, PB Gelatins GmbH, Nienburg/Weser, Germany, Tryptophan: Sigma-Aldrich, Steinheim, Germany) with TRP added to the level present in alpha-lactalbumin, as a single protein source, with either protein/carbohydrate/fat: 10/55/35 En\% (normal protein) or protein/carbohydrate/fat: 25/55/20 En\% (high protein). Protein was exchanged with fat; carbohydrate content was kept constant because its effect on protein metabolism (22). All custards had an energy density of $4 \mathrm{~kJ} / \mathrm{g}$. The breakfast contained $20 \%$ of daily energy requirement, calculated as basal metabolic rate (BMR), according to the equations of HarrisBenedict, multiplied by an activity index of 1.75 which is the average value reported for the general population in the Netherlands $(23,24)$. The mean energy content of the breakfast was $2.39 \pm 0.06 \mathrm{MJ}$.

The 14 custards were produced by NIZO Food Research bv. (Ede, The Netherlands) and had tapioca starch (Farinex VA50T, AVEBE, Veendam, The Netherlands and Perfectamyl 3108 AVEBE, Veendam, The Netherlands) and sunflower oil (Reddy, NV Vandemoortele, Roosendaal, The Netherlands) respectively as carbohydrate and fat source and were citrus-vanilla (Citrus, J.B. de lange, Belfeld, The Netherlands; Vanilla, J.B. de lange, Belfeld, The Netherlands) flavored. Extensive product development and use of a taste panel lead to custards that did not differ in color, taste, or viscosity. The amino acid composition of the 14 different custards is presented in table 1.

\section{Study protocol}

After an overnight fast from $22.00 \mathrm{~h}$, subjects came to the laboratory in the university building at 08.15h. The laboratory was a quiet room, free of odors, sounds and other disturbing factors. Subjects sat at separate tables that were at least two meter apart and were not allowed to talk to each other nor to perform any physical activity. The protocol started at $08.30 \mathrm{~h}$ with scoring appetite ratings. Breakfast was offered ( $\mathrm{t}=0$ minutes) and completed within 20 minutes. With the first and the last bite taste perception was scored. Appetite ratings were completed at 30 , $60,90,120$, and 180 minutes after breakfast. Immediately after completing the questionnaire at 180 minutes, subjects were offered an ad lib lunch and were instructed to eat just as much till they were satiated. With the first and the last bite of the lunch taste perception was scored. Appetite ratings then were completed at 210, 240, 300, and 360 minutes after breakfast. Subjects were allowed to drink maximally three glasses of water spread over the entire test period and were allowed to go home four hours after breakfast; the last two moments of rating 
were completed at home and returned on the next visit. The subjects were instructed not to perform any heavy physical activity and not to eat or drink for two hours.

Table 1 Amino acid content of the breakfasts given as a custard with either $10 \mathrm{En} \%$ or $25 \mathrm{En} \%$ casein, soy, whey, wheyGMP, alpha-lactalbumin, gelatin, or gelatin+TRP protein content (g amino acid/100 g custard)

\begin{tabular}{|c|c|c|c|c|c|c|c|}
\hline & $\begin{array}{c}\text { casein } \\
10 \%\end{array}$ & $\begin{array}{l}\text { soy } \\
10 \%\end{array}$ & $\begin{array}{l}\text { whey } \\
10 \%\end{array}$ & $\begin{array}{c}\text { whey-GMP } \\
10 \%\end{array}$ & $\begin{array}{c}\text { alpha- } \\
\text { lactalbumin 10\% }\end{array}$ & $\begin{array}{c}\text { gelatin } \\
10 \%\end{array}$ & $\begin{array}{c}\text { gelatin+TRP } \\
10 \%\end{array}$ \\
\hline Glutamic acid $^{\text {a }}$ & 0.477 & 0.328 & 0.381 & 0.378 & 0.316 & 0.229 & 0.229 \\
\hline 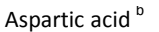 & 0.150 & 0.200 & 0.230 & 0.252 & 0.360 & 0.127 & 0.127 \\
\hline Cysteine & 0.009 & 0.022 & 0.055 & 0.071 & 0.115 & 0.001 & 0.001 \\
\hline Serine & 0.120 & 0.089 & 0.099 & 0.088 & 0.095 & 0.074 & 0.074 \\
\hline Histidine & 0.064 & 0.048 & 0.039 & 0.047 & 0.065 & 0.021 & 0.021 \\
\hline Glycine & 0.040 & 0.071 & 0.035 & 0.038 & 0.059 & 0.558 & 0.558 \\
\hline Threonine & 0.090 & 0.066 & 0.150 & 0.106 & 0.114 & 0.042 & 0.042 \\
\hline Arginine & 0.092 & 0.139 & 0.055 & 0.067 & 0.043 & 0.191 & 0.191 \\
\hline Alanine & 0.064 & 0.073 & 0.106 & 0.105 & 0.056 & 0.211 & 0.211 \\
\hline Tyrosine & 0.120 & 0.069 & 0.061 & 0.079 & 0.100 & 0.011 & 0.011 \\
\hline Valine & 0.141 & 0.085 & 0.123 & 0.113 & 0.103 & 0.051 & 0.051 \\
\hline Methionine & 0.064 & 0.022 & 0.048 & 0.051 & 0.028 & 0.019 & 0.019 \\
\hline Isoleucine & 0.112 & 0.089 & 0.141 & 0.126 & 0.136 & 0.035 & 0.035 \\
\hline Phenylalanine & 0.110 & 0.094 & 0.062 & 0.078 & 0.094 & 0.042 & 0.042 \\
\hline Tryptophan & 0.027 & 0.023 & 0.039 & 0.050 & 0.090 & 0.001 & 0.087 \\
\hline Leucine & 0.204 & 0.145 & 0.226 & 0.277 & 0.257 & 0.067 & 0.067 \\
\hline Lysine & 0.172 & 0.110 & 0.201 & 0.230 & 0.246 & 0.087 & 0.087 \\
\hline \multirow[t]{3}{*}{ Proline } & 0.230 & 0.087 & 0.128 & 0.097 & 0.057 & 0.316 & 0.316 \\
\hline & casein & soy & whey & whey-GMP & alpha- & gelatin & gelatin+TRP \\
\hline & $25 \%$ & $25 \%$ & $25 \%$ & $25 \%$ & lactalbumin $25 \%$ & $25 \%$ & $25 \%$ \\
\hline Glutamic acid $^{a}$ & 1.127 & 0.816 & 0.957 & 0.922 & 0.790 & 0.576 & 0.576 \\
\hline 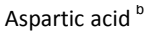 & 0.355 & 0.497 & 0.579 & 0.615 & 0.901 & 0.319 & 0.319 \\
\hline Cysteine & 0.021 & 0.054 & 0.139 & 0.172 & 0.288 & 0.002 & 0.002 \\
\hline Serine & 0.283 & 0.220 & 0.249 & 0.216 & 0.239 & 0.186 & 0.186 \\
\hline Histidine & 0.152 & 0.119 & 0.097 & 0.115 & 0.162 & 0.052 & 0.052 \\
\hline Glycine & 0.094 & 0.177 & 0.088 & 0.092 & 0.148 & 1.402 & 1.402 \\
\hline Threonine & 0.214 & 0.164 & 0.378 & 0.259 & 0.285 & 0.106 & 0.106 \\
\hline Arginine & 0.218 & 0.345 & 0.139 & 0.164 & 0.106 & 0.479 & 0.479 \\
\hline Alanine & 0.150 & 0.182 & 0.266 & 0.255 & 0.140 & 0.530 & 0.530 \\
\hline Tyrosine & 0.283 & 0.171 & 0.154 & 0.192 & 0.249 & 0.027 & 0.027 \\
\hline Valine & 0.333 & 0.212 & 0.309 & 0.275 & 0.259 & 0.129 & 0.129 \\
\hline Methionine & 0.152 & 0.056 & 0.121 & 0.125 & 0.069 & 0.048 & 0.048 \\
\hline Isoleucine & 0.265 & 0.222 & 0.355 & 0.307 & 0.339 & 0.087 & 0.087 \\
\hline Phenylalanine & 0.259 & 0.234 & 0.156 & 0.189 & 0.235 & 0.107 & 0.107 \\
\hline Tryptophan & 0.064 & 0.057 & 0.099 & 0.123 & 0.225 & 0.003 & 0.219 \\
\hline Leucine & 0.483 & 0.360 & 0.567 & 0.675 & 0.644 & 0.168 & 0.168 \\
\hline Lysine & 0.405 & 0.274 & 0.504 & 0.560 & 0.614 & 0.219 & 0.219 \\
\hline Proline & 0.544 & 0.216 & 0.321 & 0.238 & 0.142 & 0.792 & 0.792 \\
\hline
\end{tabular}

${ }^{\text {a }}$ Glutamic acid = glutamine + glutamate

${ }^{\mathrm{b}}$ Aspartic acid = asparagine 


\section{Measurements}

Energy intake at lunch

Lunch consisted of Turkish bread (400 g) with egg salad (400 g) with 13/41/46 En\% protein/carbohydrate/fat with an energy density of $11.4 \mathrm{~kJ} / \mathrm{g}$. Subjects were instructed to eat till they were comfortably full. Lunch was weighed before and after eating and energy intake was calculated.

\section{Appetite profile}

To determine the appetite profile, hunger, fullness, satiety, and desire to eat were rated on 100 $\mathrm{mm}$ Visual Analogue Scales (VAS), anchored with 'not at all' and 'extremely'. Subjects were instructed to rate the appetite dimensions by marking the scale at the point that was most appropriate to their feeling at that time.

\section{Taste perception}

Taste perception profiles of the custards and lunch were assessed after the first and the last bite using $100 \mathrm{~mm}$ Visual Analogue Scales (VAS), anchored with 'not at all' and 'extremely' on the aspects: pleasantness, sweetness, sourness, saltiness, bitterness, savouriness, crispiness, and creaminess.

\section{Statistical analysis}

Data are presented as mean changes from baseline \pm standard error to the mean (SEM), unless otherwise indicated (25). The area under the curve (AUC) of changes from baseline till 180 minutes after breakfast (AUC180) was calculated using the trapezoidal method. To determine possible differences between the different types of protein at a concentration of $10 \%$ and $25 \%$ of energy from protein, a repeated measures ANOVA between factors with protein concentration as factor was carried out. When there was no effect of protein concentration a repeated measures ANOVA with Fisher's PLSD correction for multiple comparisons within one protein type was carried out. Regression analysis was performed to determine the relationships between the difference in energy intake between two different breakfasts and the difference in AUC of hunger or satiety after these two different breakfasts. Glucose, insulin, GLP-1, ghrelin, and amino acid concentrations between different protein types within one concentration were compared using the Mann-Whitney $U$ test (16-18). A p-value $<0.05$ was regarded as statistically significant. Statistical procedures were performed using StatView 5.0 (SAS Institute Inc., USA, 1998).

\section{RESULTS}

\section{Energy intake}

Energy intake at lunch did not differ depending on protein concentration with respect to comparisons between different protein types. After a breakfast with $10 \%$ of energy from protein, energy intake at lunch was $0.54 \mathrm{MJ}(17 \%)$ lower after a breakfast with alpha- 
lactalbumin, gelatin, or gelatin+TRP than after a breakfast with casein, soy, or whey-GMP ( $p<0.05$, figure 1). After a breakfast with $25 \%$ of energy from protein, energy intake at lunch was $0.78 \mathrm{MJ}(24 \%)$ lower after a breakfast with alpha-lactalbumin, gelatin, or gelatin+TRP than after a breakfast with casein, soy, or whey-GMP ( $p<0.05$, figure 1 ). Energy intake at lunch was also $0.55 \mathrm{MJ}(19 \%)$ lower after a breakfast with alpha-lactalbumin or gelatin+TRP than after a breakfast with whey ( $p<0.01$, figure 1$)$.
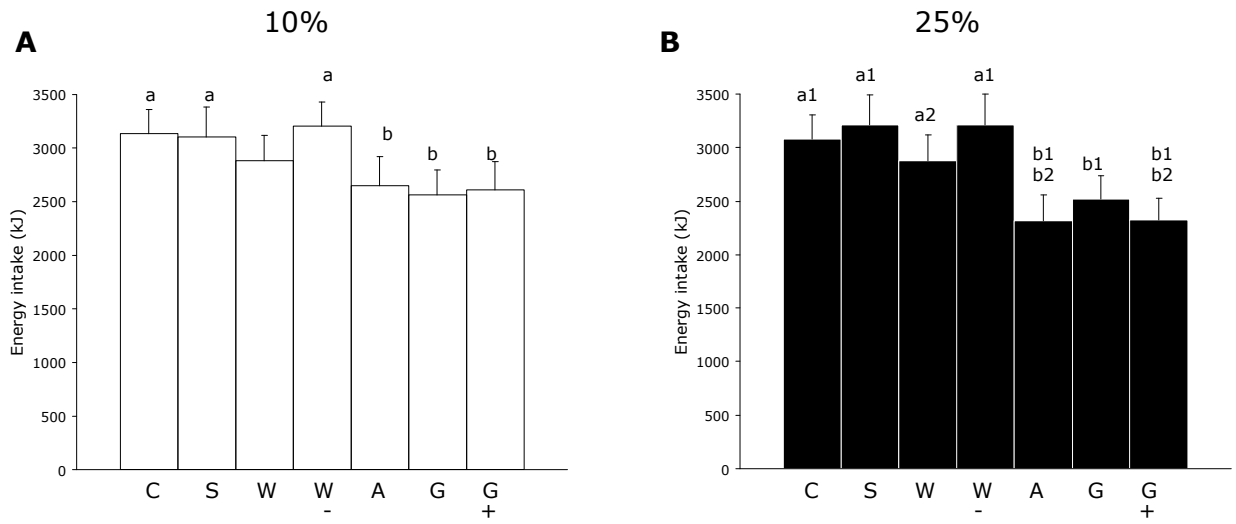

Figure $1 \mathrm{Ad}$ lib energy intake (kJ) at lunch after consumption of a breakfast with 20\% of daily energy requirements with either $10 \mathrm{En} \%$ (A) or $25 \mathrm{En \%}$ (B) from protein with either casein, soy, whey, whey-GMP, alpha-lactalbumin, gelatin, or gelatin+TRP as protein type in 24 subjects (men and women). Values are means + SEM, ANOVA repeated measures with Fisher's PLSD correction. C casein, S soy, W whey, W- whey-GMP, A alpha-lactalbumin, G gelatin, G+ gelatin+TRP. a significantly different from $b(p<0.05)$, a1 significantly different from b1 $(p<0.05)$, a2 significantly different from b2 ( $<<0.05)$

\section{Taste perception breakfast}

Pleasantness of taste of the custards with the first bite was sufficient with a mean value of $55 \pm 5$ $\mathrm{mm}$ without differences between custards.

\section{Satiety and hunger}

Baseline ratings for satiety or hunger were not different between treatments. The changes in appetite ratings did not differ depending on protein concentration with respect to comparisons between different protein types. Within one protein concentration there were various significant differences in the change in satiety or hunger between the seven different breakfasts at several time points, both at the level of $10 \%$ and $25 \%$ of energy from protein (figure 2). Changes in fullness or desire to eat were similar to the changes in satiety or hunger respectively and are therefore not presented separately. The differences in appetite ratings between types of protein at 180 minutes after breakfast were 30 to $50 \%$ (figure 2).

The AUC of changes in appetite ratings over the first three hours after breakfast, i.e. the AUC180 of satiety or hunger suppression was larger in general after the breakfast with alphalactalbumin, gelatin, and/or gelatin+TRP than after casein, soy, whey, and/or whey-GMP, both at $10 \%$ and $25 \%$ of energy from protein (figure 2 ). 
A

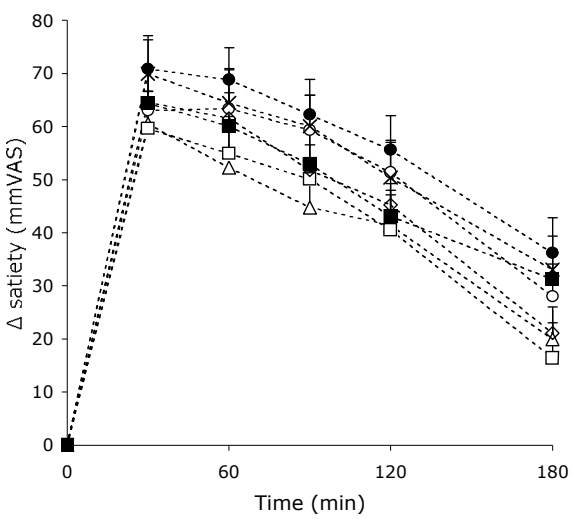

C

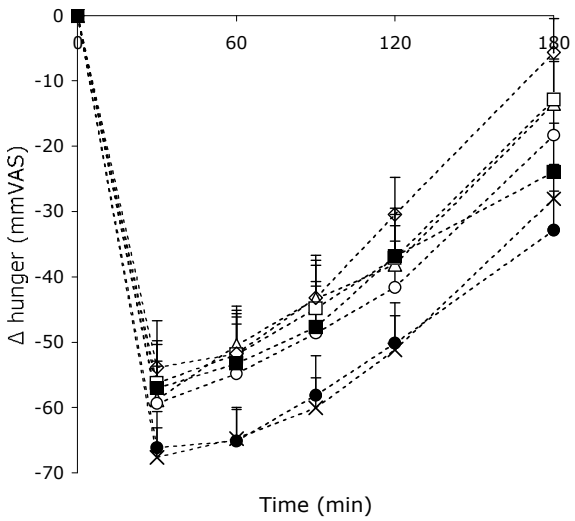

B

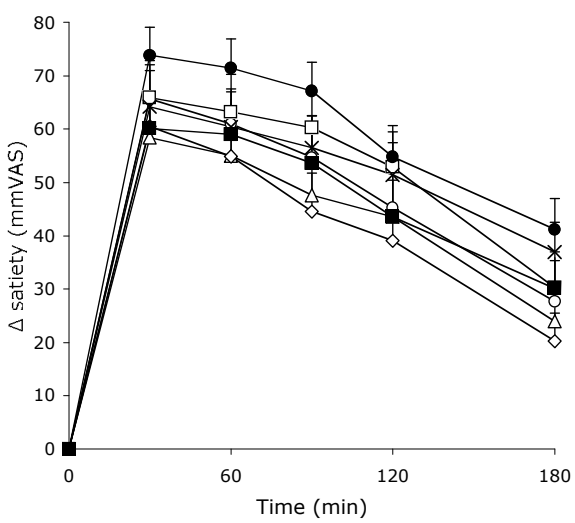

D

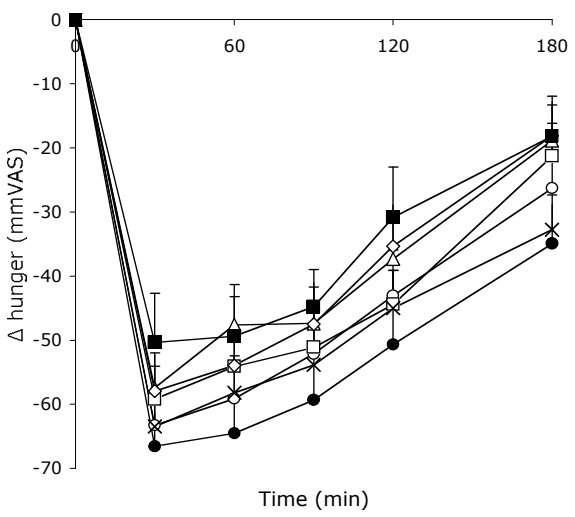

Figure 2 Changes in satiety and hunger (mmVAS) after consumption of a breakfast with $20 \%$ of daily energy requirements with either $10 \mathrm{En} \%(\mathrm{~A}+\mathrm{C})$ or $25 \mathrm{En} \%(\mathrm{~B}+\mathrm{D})$ from protein with either casein, soy, whey, whey-GMP, alpha-lactalbumin, gelatin, or gelatin+TRP as protein type in 24 subjects (men and women). Values are means + SEM, ANOVA repeated measures with Fisher's PLSD correction. --- $\triangle$ casein $10 \%,---\bigcirc$ soy $10 \%,---\square$ whey $10 \%,---\diamond$ whey-GMP $10 \%,---\times$ alpha-lactalbumin $10 \%$, $---\square$ gelatin $10 \%,--\bullet$ gelatin+TRP $10 \%,-\triangle$ casein $25 \%,-\bigcirc$ soy $25 \%,-\square$ whey $25 \%,-\diamond$ whey-GMP $25 \%,-X$ alphalactalbumin 25\%, - gelatin 25\%, — gelatin+TRP 25\% Significant differences $*$ p $<0.05$ A: 90 min.: alphalactalbumin/gelatin+TRP > casein/whey *; $180 \mathrm{~min}$.: alpha-lactalbumin/gelatin/gelatin+TRP > casein/ whey/whey-GMP *; Area Under the Curve: alpha-lactalbumin>casein/whey ${ }^{*}$, gelatin+TRP>casein/whey ${ }^{*}$ B: 90 min.: gelatin+TRP > casein/soy/whey-GMP *;180 min.: alpha-lactalbumin/gelatin+TRP > casein/soy/ whey-GMP *; Area Under the Curve: whey>whey-GMP *, gelatin+TRP>casein/soy/whey-GMP/gelatin * C: $30 \mathrm{~min} .:$ alpha-lactalbumin/gelatin+TRP > whey/wheyGMP *; 60 min.: alpha-lactalbumin/gelatin+TRP > casein/whey/whey-GMP *; $90 \mathrm{~min} .:$ alpha-lactalbumin/gelatin+TRP > casein/soy/whey/whey-GMP *; $120 \mathrm{~min} .:$ alpha-lactalbumin/gelatin+TRP > casein/whey/whey-GMP *; $180 \mathrm{~min} .:$ alphalactalbumin/gelatin/gelatin+TRP > casein/soy/whey/whey-GMP *; Area Above the Curve: alphalactalbumin>casein/whey/whey-GMP/gelatin $*$, gelatin+TRP>casein/whey/whey-GMP/gelatin $*$ D: 60 min.: alphalactalbumin/gelatin+TRP > casein/whey-GMP *;120 min.: gelatin+TRP > casein/whey-GMP *; $180 \mathrm{~min} .:$ alphalactalbumin/gelatin+TRP > casein/whey/whey-GMP * Area Above the Curve: soy>gelatin *, alpha-lactalbumin $>$ gelatin *, gelatin+TRP>casein/whey-GMP/gelatin * 


\section{Correlations}

Comparison of the different protein breakfast types at a concentration of $10 \%$ of energy from protein revealed that the difference in energy intake at lunch between a breakfast with gelatin+TRP and a breakfast with soy was a function of the difference in the AUC180 of satiety between those two breakfasts $(r=-0.470, p<0.05)$, the difference in energy intake at lunch between a breakfast with gelatin and a breakfast with whey-GMP was a function of the differences in the AUC180 of satiety or the AUC180 of hunger between those two breakfasts ( $r=-$ $0.641, p<0.001$; and $r=0.481, p<0.05$ respectively), and the difference in energy intake at lunch between a breakfast with gelatin+TRP and whey-GMP was a function of the differences in the AUC180 of satiety or the AUC180 of hunger between those two breakfasts ( $r=-0.446, p<0.05$; $r=0.414, p<0.05$ respectively).

Comparison of the different protein types at a concentration of $25 \%$ of energy from protein revealed that the difference in energy intake at lunch between a breakfast with gelatin+TRP and a breakfast with soy a function was of the difference in the AUC180 of satiety or the AUC180 of hunger between those two breakfasts $(r=-0.571, p<0.01 ; r=0.458, p<0.05$ respectively).

\section{Blood parameters}

The comparison of glucose, insulin, GLP-1, ghrelin, and amino acid concentrations, obtained during the preceding experiments (16-18), revealed that there were several significant differences in metabolite responses between the different protein breakfasts. These differences are presented in table $\mathbf{2 A}$ and $\mathbf{2 B}$.

In general, responses of essential amino acids were more increased after a breakfast with casein, whey, whey-GMP or alpha-lactalbumin than after a breakfast with gelatin or gelatin+TRP. For the non-essential amino acids some amino acid responses were more increased after a breakfast with gelatin or gelatin+TRP compared with casein, soy, whey, whey-GMP or alpha-lactalbumin whereas for other amino acids it was the other way around. 


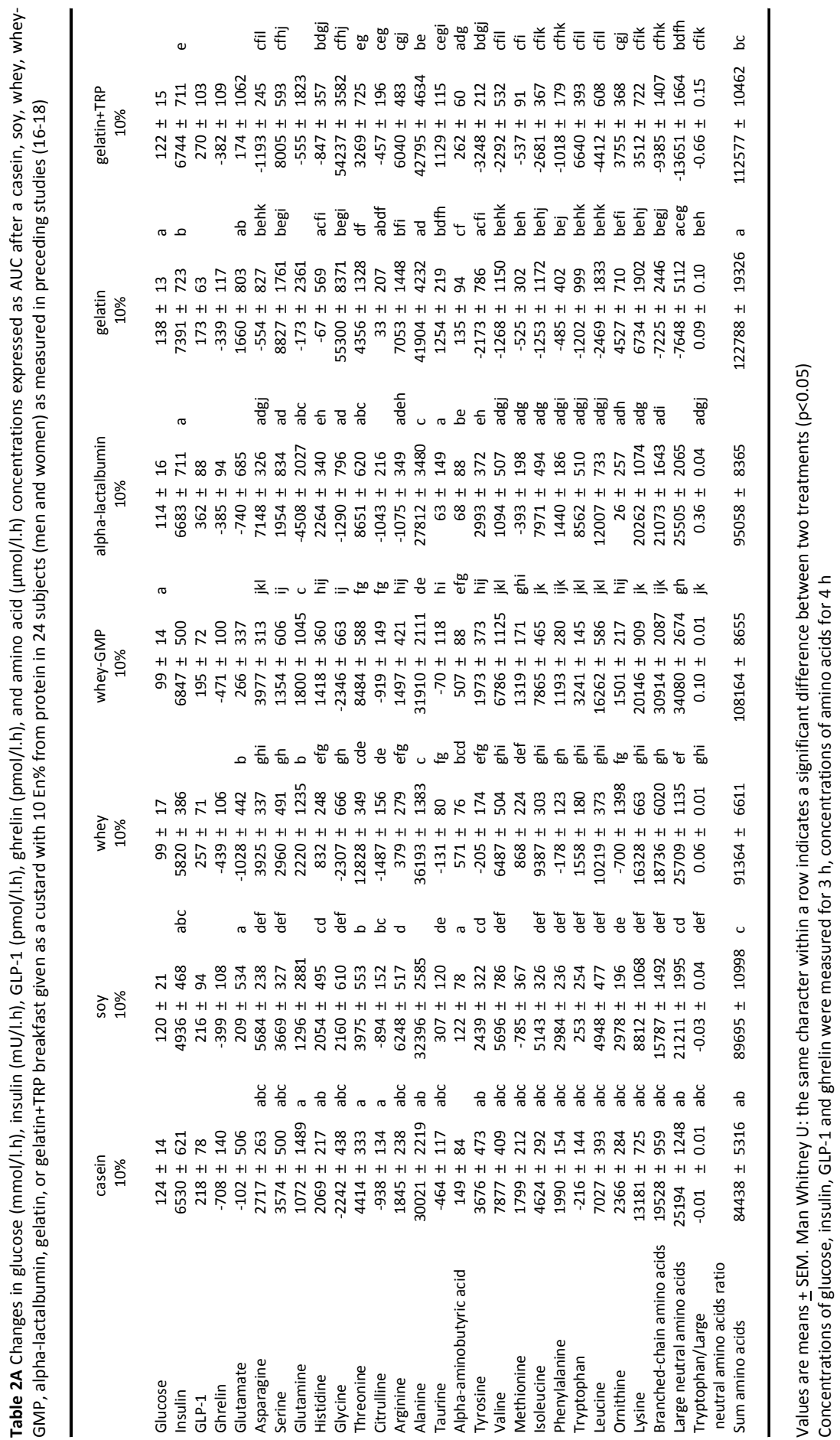




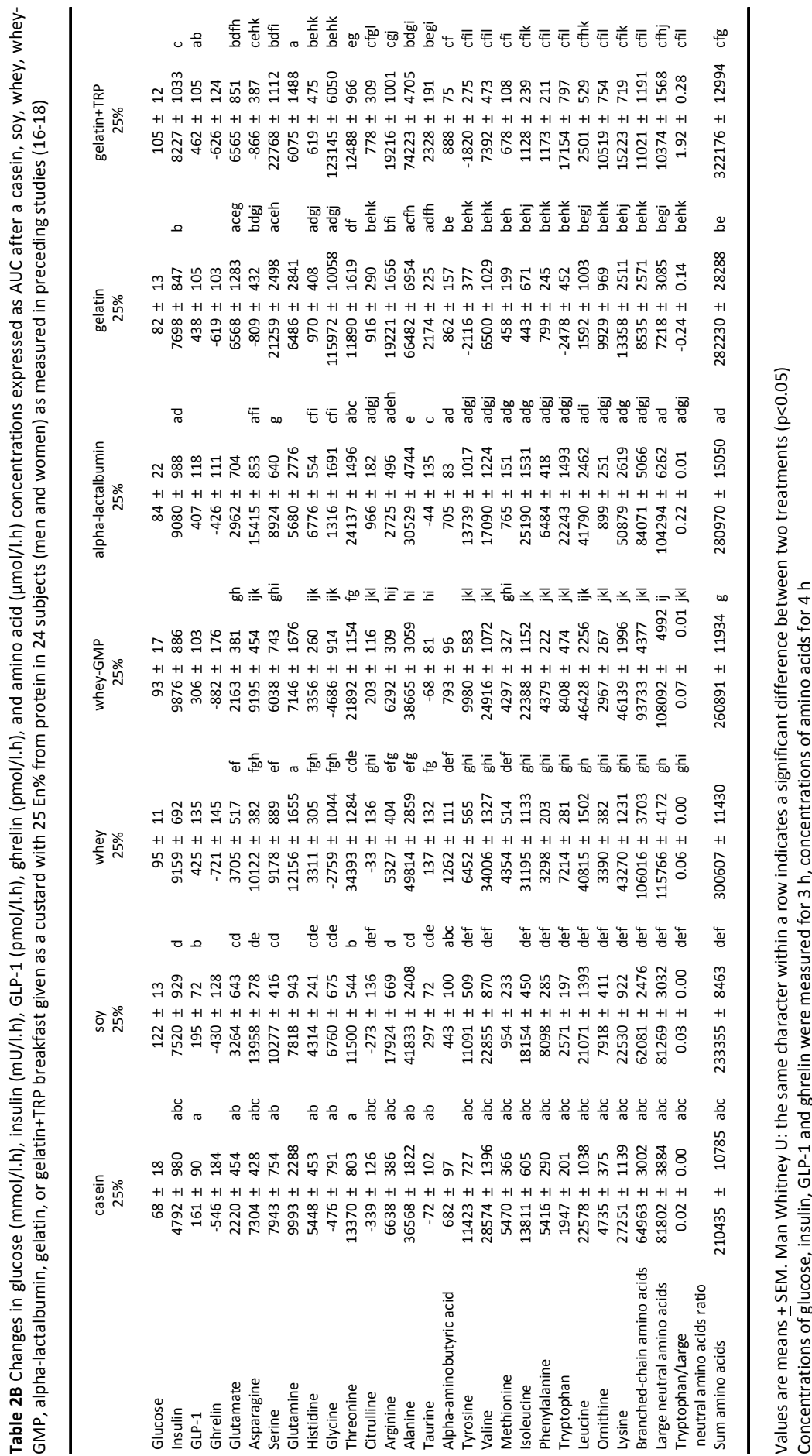




\section{DISCUSSION}

Ad lib energy intake at lunch was $\sim 20 \%$ lower after a breakfast with alpha-lactalbumin, gelatin, or gelatin+TRP than after a breakfast with casein, soy, or whey-GMP, both at the level of $10 \%$ and $25 \%$ of energy from protein. Moreover, ad lib energy intake at lunch also was lower after a breakfast with $25 \%$ of energy from alpha-lactalbumin or gelatin+TRP in comparison with a breakfast with $25 \%$ of energy from whey. The iso-energetic custards consumed for breakfast were of the same color and viscosity and did not differ in taste. To explain the differences in energy intake at lunch we explored differences in appetite ratings, glucose, insulin, GLP-1, ghrelin, and amino acid concentrations.

One of the explanations for the observed differences in energy intake at lunch were differences in appetite ratings after consumption of the different protein breakfasts. The differences in energy intake between two treatments indeed were a function of the difference in appetite ratings between those two treatments; reduced energy intake thus was indeed straightforwardly related to increased satiety. Alpha-lactalbumin, gelatin, and gelatin+TRP were more satiating than casein, soy, whey, and whey-GMP resulting in a decreased energy intake.

A mechanism for the increased satiety and decreased energy intake may be the increased insulin response, a metabolic satiety signal $(26,27)$, after a breakfast with alpha-lactalbumin, gelatin, or gelatin+TRP compared with a breakfast with casein or soy. Moreover, there was an increased GLP-1 response after a breakfast with $25 \%$ of energy from gelatin+TRP compared with a breakfast with $25 \%$ of energy from casein or soy. Previously, GLP-1 has been found to inhibit appetite and reduce food intake in normal-weight men. GLP-1 possibly exerts its effects via a combination of inhibition of gastric emptying and activation of brain GLP-1 receptors that limits food intake $(21,28)$. Increased concentrations of amino acids may also contribute to increased satiety since, according to the amino static theory of Melinkoff from 1956, a larger increase in plasma amino acids increases satiety (29). There were several amino acids that were relatively more increased after a breakfast with alpha-lactalbumin, gelatin, or gelatin+TRP than after a breakfast with casein. soy, whey, or whey-GMP. However, there was no specific amino acid that was more increased after all the three satiating breakfasts compared with the less satiating breakfasts. Therefore it appears that amino acids do play a role in the satiety response but that each protein has its own mechanisms via which satiety is induced.

Responses of essential amino acid concentrations in the blood in general were larger after a breakfast with casein, whey, whey-GMP or alpha-lactalbumin than after a breakfast with gelatin or gelatin+TRP, which is a reflection of the amino acid composition of the proteins used. An 'ideal protein', with all essential amino acids present in the right amounts, would reflect the Recommended Daily Allowances of essential amino acids, being $14 \mathrm{mg} / \mathrm{kg} / \mathrm{day}$ histidine, 19 $\mathrm{mg} / \mathrm{kg} / \mathrm{day}$ isoleucine, $42 \mathrm{mg} / \mathrm{kg} /$ day leucine, $38 \mathrm{mg} / \mathrm{kg} /$ day lysine, $19 \mathrm{mg} / \mathrm{kg} / \mathrm{day}$ methionine+cysteine, $33 \mathrm{mg} / \mathrm{kg} /$ day phenylalanine+tyrosine, $20 \mathrm{mg} / \mathrm{kg} /$ day threonine, 5 $\mathrm{mg} / \mathrm{kg} /$ day tryptophan and $24 \mathrm{mg} / \mathrm{kg} /$ day valine (30). This means a distribution with $7 \%$ of essential amino acids as histidine, $9 \%$ as isoleucine, $20 \%$ as leucine, $18 \%$ as lysine, $9 \%$ as methionine+cysteine, $15 \%$ as phenylalanine+tyrosine, $9 \%$ as threonine, $2 \%$ as tryptophan and $11 \%$ as valine. From the proteins we used, casein comes closest to this amino acid composition whereas gelatin is the protein with the worst quality. Gelatin is an incomplete protein and it may 
be hypothesized that the oxidation of gelatin has high energy costs. This may induce an increased satiety, since a positive relationship was observed between energy expenditure and satiety by Westerterp-Plantenga et al. (31). Hochstenbach-Waelen et al. indeed showed an increased energy expenditure and a decreased hunger and desire to eat after a high gelatin diet compared with a normal gelatin diet for 36 hours (32). An increased energy expenditure may be the mechanism for gelatin to induce an increased satiety and reduce subsequent energy intake. Alpha-lactalbumin is a relatively complete protein, nevertheless it also increased satiety compared with other types of protein, so other mechanisms are also involved in protein-induced satiety.

Our results show that with breakfasts with different protein types a significant difference in energy intake at lunch is likely to be achieved if the difference in induced satiety is considerably; 15 to $25 \mathrm{~mm}$ on a Visual Analogue Scale a 40\% increased satiety. Apparently when differences were smaller it was not enough to induce significant effects on energy intake.

Timing of the moment when an ad lib meal is offered is important in evaluating the satiating properties of protein (8). Hall et al. report a significantly lower energy intake following a whey protein preload compared with a casein preload (3). However, the buffet meal was offered at 90 minutes after the preloads, when effects of casein have not been fully developed, and therefore probably is too soon to be a realistic and sensitive moment to measure differences in energy intake. On the other hand, it should be prevented that differences in appetite ratings or 'satiety' hormone levels have become extinguished over time. Despite appetite ratings suggesting that gelatin was more satiating than casein, Lang et al. did not observe significant differences in energy intake and macronutrient intake at dinner or over $\mathbf{2 4}$ hours after a test lunch with casein, gelatin, or soy protein (7). However, dinner was offered eight hours after lunch, so the differences in satiety may have diminished by this time. We therefore determined the most sensitive time point to offer lunch in preceding experiments (16-18).

Apart from the experiments by Hall and Lang mentioned above $(3,7)$ only a limited number of human studies describe a comparison of different protein types with respect to their effects on energy intake or satiety. A comparison of beef, chicken, and fish protein revealed that fish protein increased satiety compared with the other protein types; food intake afterwards was not measured (33). In a series of preceding studies, we showed that energy intake at lunch was decreased after a breakfast with whey compared a breakfast with whey-GMP (17), that whey was more satiating than casein or soy protein at a level of $10 \%$ of energy from protein in a breakfast (16) and that hunger was more suppressed after a breakfast with $10 \%$ of energy from alpha-lactalbumin compared with a breakfast with $10 \%$ of energy from gelatin or gelatin+TRP (18). Lang and colleagues did not observe significantly different effects of egg albumin, casein, gelatin, soy, pea, or wheat gluten on appetite scores or energy intake, probably because of the presence of other proteins (6). A study by Bowen et al. evaluated the effect of casein or whey protein preload on indicators of appetite and food intake, however, no differences in appetite or food intake between casein and whey were observed (4). In another study of Bowen et al. no difference was found in appetite ratings and energy intake after whey, soy, or gluten preload (5). The results of this study may be used in a weight-loss diet. When people feel less hungry and desire to eat is suppressed, it is easier for them to comply to a diet because they really feel an effect of the diet and then they will actually eat less, as has been previously shown in experiments by Skov et al. (34) and Weigle et al. (2). Alpha-lactalbumin and gelatin (+TRP) were 
more satiating than the other types of protein and thus may help to feel subjects to feel less hungry and comply to their weight-loss diet. Gelatin is an incomplete protein and can not be offered as the single protein type in a diet, however addition of this protein to a diet with other high quality proteins present may have beneficial effects on the compliance to the diet.

Summarizing, alpha-lactalbumin, gelatin, or gelatin+TRP containing breakfasts caused a $\sim 20 \%$ lower energy intake at lunch than a casein, soy, or whey-GMP breakfast, both at the level of $10 \%$ and $25 \%$ of energy from protein. Alpha-lactalbumin and gelatin+TRP breakfasts also reduced energy intake compared with a breakfast with whey at the level of $25 \%$ of energy from protein. The reduced energy intake of $20 \%$ was related to a $\sim 40 \%$ reduction in appetite. In conclusion, different proteins (alpha-lactalbumin, gelatin, and gelatin+TRP) that are $30-50 \%$ more satiating than other proteins (casein, soy, whey, and whey-GMP) induce a related $17-24 \%$ reduction of subsequent energy intake.

\section{ACKNOWLEDGEMENTS}

MABV, AGN, AH-W, KRW, MPKJE, RJMB, NEPD, and MSW-P designed the study. MABV and AH$W$ collected and analyzed the data. MABV wrote the manuscript and AGN, KRW, MPKJE, NEPD, and MSW-P contributed to interpretation of the data and reviewed the manuscript. The study was executed under supervision of AGN, KRW, and MSW-P. None of the authors had a personal or financial conflict of interest.

\section{REFERENCES}

1. Westerterp-Plantenga MS, Luscombe-Marsh N, Lejeune MP, et al. Dietary protein, metabolism, and bodyweight regulation: dose-response effects. Int J Obes (Lond) 2006;30 Suppl 3:S16-23.

2. Weigle DS, Breen PA, Matthys CC, et al. A high-protein diet induces sustained reductions in appetite, ad libitum caloric intake, and body weight despite compensatory changes in diurnal plasma leptin and ghrelin concentrations. Am J Clin Nutr 2005;82:41-8.

3. Hall WL, Millward DJ, Long SJ, Morgan LM. Casein and whey exert different effects on plasma amino acid profiles, gastrointestinal hormone secretion and appetite. Br J Nutr 2003;89:239-48.

4. Bowen J, Noakes M, Trenerry C, Clifton PM. Energy intake, ghrelin, and cholecystokinin after different carbohydrate and protein preloads in overweight men. J Clin Endocrinol Metab 2006;91:1477-83.

5. Bowen J, Noakes M, Clifton PM. Appetite regulatory hormone responses to various dietary proteins differ by body mass index status despite similar reductions in ad libitum energy intake. J Clin Endocrinol Metab 2006;91:2913-9.

6. Lang V, Bellisle F, Oppert JM, et al. Satiating effect of proteins in healthy subjects: a comparison of egg albumin, casein, gelatin, soy protein, pea protein, and wheat gluten. Am J Clin Nutr 1998;67:1197-204.

7. Lang V, Bellisle F, Alamowitch C, et al. Varying the protein source in mixed meal modifies glucose, insulin and glucagon kinetics in healthy men, has weak effects on subjective satiety and fails to affect food intake. Eur J Clin Nutr 1999;53:959-65.

8. Anderson GH, Tecimer SN, Shah D, Zafar TA. Protein source, quantity, and time of consumption determine the effect of proteins on short-term food intake in young men. J Nutr 2004;134:3011-5.

9. Spaaij CJ, Pijls LT. New dietary reference intakes in the Netherlands for energy, proteins, fats and digestible carbohydrates. Eur J Clin Nutr 2004;58:191-4.

10. Boirie Y, Dangin M, Gachon P, Vasson MP, Maubois JL, Beaufrere B. Slow and fast dietary proteins differently modulate postprandial protein accretion. Proc Natl Acad Sci U S A 1997;94:14930-5.

11. Dangin M, Boirie $\mathrm{Y}$, Garcia-Rodenas $\mathrm{C}$, et al. The digestion rate of protein is an independent regulating factor of postprandial protein retention. Am J Physiol Endocrinol Metab 2001;280:E340-8.

12. Dangin M, Boirie Y, Guillet C, Beaufrere B. Influence of the protein digestion rate on protein turnover in young and elderly subjects. J Nutr 2002;132:3228S-33S. 
13. Marshall K. Therapeutic applications of whey protein. Altern Med Rev 2004;9:136-56

14. Pedersen NL, Nagain-Domaine C, Mahe S, Chariot J, Roze C, Tome D. Caseinomacropeptide specifically stimulates exocrine pancreatic secretion in the anesthetized rat. Peptides 2000;21:1527-35.

15. Beulens JW, Bindels JG, de Graaf C, Alles MS, Wouters-Wesseling W. Alpha-lactalbumin combined with a regular diet increases plasma Trp-LNAA ratio. Physiol Behav 2004;81:585-93.

16. Veldhorst MA, Nieuwenhuizen AG, Hochstenbach-Waelen A, et al. Dose-dependent satiating effect of whey relative to casein or soy. Physiol Behav 2009;96:675-82.

17. Veldhorst MA, Nieuwenhuizen AG, Hochstenbach-Waelen A, et al. Effects of complete whey-protein breakfasts versus whey without GMP-breakfasts on energy intake and satiety. Appetite 2009;52:388-95.

18. Nieuwenhuizen AG, Hochstenbach-Waelen A, Veldhorst MA, et al. Acute effects of breakfasts containing alphalactalbumin, or gelatin with or without added tryptophan, on hunger, 'satiety' hormones and amino acid profiles. Br J Nutr 2009;101:1859-66.

19. Stunkard AJ, Messick S. The three-factor eating questionnaire to measure dietary restraint, disinhibition and hunger. J Psychosom Res 1985;29:71-83.

20. Westerterp-Plantenga MS, Westerterp KR, Rubbens M, Verwegen CR, Richelet JP, Gardette B. Appetite at "high altitude" [Operation Everest III (Comex-'97)]: a simulated ascent of Mount Everest. J Appl Physiol 1999;87:3919.

21. Adam TC, Westerterp-Plantenga MS. Nutrient-stimulated GLP-1 release in normal-weight men and women Horm Metab Res 2005;37:111-7.

22. Munro HN. Second Boyd Orr Memorial Lecture. Regulation of body protein metabolism in relation to diet. Proc Nutr Soc 1976;35:297-308.

23. Harris JA, Benedict FG. A biometric study of basal metabolism in man. Proc Natl Acad Sci 1918;4:370-373.

24. Westerterp KR, Kester AD. Physical activity in confined conditions as an indicator of free-living physical activity. Obes Res 2003;11:865-8.

25. Senn S. Cross-over trials in Statistics in Medicine: The first '25' years. Statistics in Medicine 2006;25:3430-3442

26. Woods SC, Chavez M, Park CR, et al. The evaluation of insulin as a metabolic signal influencing behavior via the brain. Neurosci Biobehav Rev 1996;20:139-44.

27. VanderWeele DA. Insulin is a prandial satiety hormone. Physiol Behav 1994;56:619-22.

28. Flint A, Raben A, Astrup A, Holst JJ. Glucagon-like peptide 1 promotes satiety and suppresses energy intake in humans. J Clin Invest 1998;101:515-20.

29. Mellinkoff SM, Frankland M, Boyle D, Greipel M. Relationship between serum amino acid concentration and fluctuations in appetite. J Appl Physiol 1956;8:535-8.

30. (FNB) FaNB. Dietary Reference Intakes for Energy, Carbohydrate, Fiber, Fat, Fatty Acids, Cholesterol, Protein, and Amino Acids (Macronutrients)

A Report of the Panel on Macronutrients, Subcommittees on Upper Reference Levels of Nutrients and Interpretation and Uses of Dietary Reference Intakes, and the Standing Committee on the Scientific Evaluation of Dietary Reference Intakes. Washington, D.C: INSTITUTE OF MEDICINE OF THE NATIONAL ACADEMIES THE NATIONAL ACADEMIES PRESS, 2005.

31. Westerterp-Plantenga MS, Rolland V, Wilson SA, Westerterp KR. Satiety related to $24 \mathrm{~h}$ diet-induced thermogenesis during high protein/carbohydrate vs high fat diets measured in a respiration chamber. Eur J Clin Nutr 1999;53:495-502.

32. Hochstenbach-Waelen A, Veldhorst MAB, Nieuwenhuizen AG, Westerterp-Plantenga MS, Westerterp KR. Effects of gelatin in a 25 vs 10 energy\% single protein diet on energy expenditure, substrate balances and appetite. In revision 2009.

33. Uhe AM, Collier GR, O'Dea K. A comparison of the effects of beef, chicken and fish protein on satiety and amino acid profiles in lean male subjects. J Nutr 1992;122:467-72.

34. Skov AR, Toubro S, Ronn B, Holm L, Astrup A. Randomized trial on protein vs carbohydrate in ad libitum fat reduced diet for the treatment of obesity. Int J Obes Relat Metab Disord 1999;23:528-36. 
Chapter 8

Protein-induced appetite suppression is affected by the presence or absence of carbohydrates

Veldhorst MAB, Westerterp KR, van Vught JAH, Westerterp-Plantenga MS

Submitted for publication 


\section{ABSTRACT}

Background: Two types of high protein diets, with a normal or low proportion of carbohydrates, have been shown to be effective for weight loss.

Objective: To assess the significance of the presence or absence of carbohydrates in high protein diets for affecting appetite suppression, energy expenditure, and fat oxidation.

Methods: Forty-five subjects (mean \pm stdev: age: $23 \pm 3 y$, BMI: $22.0 \pm 1.9 \mathrm{~kg} / \mathrm{m}^{2}$ ) were stratified in two groups, each was offered two diets in a randomized crossover design; group $1(n=22)$ : normal protein (NP, 10/60/30 En\% protein/carbohydrate/fat), high protein (HP, 30/40/30); group 2 ( $n=23$ ): normal protein (NP-g, 10/60/30), or high protein,carbohydrate-free (HP-OC, 30/0/70) for two days; NP-g and HP-OC were preceded by glycogen-lowering exercise (day 1 ). Hunger and satiety were measured throughout day 2 using Visual Analogue Scales (VAS). Energy expenditure (EE) and substrate oxidation (RQ) were measured in a respiration chamber $(08.00 \mathrm{~h}$ day 2-07.30h day 3). Fasting plasma $\beta$-hydroxybutyrate (BHB) concentration was measured (day 3).

Results: NP-g and NP did not differ in hunger, EE, RQ, and BHB. HP and HP-OC vs. NP and NP-g respectively, were lower in hunger $(p<0.05 ; p<0.001)$ and $R Q(p<0.01 ; p<0.001)$ and higher in EE $(p<0.05 ; p=0.07)$ and $B H B(p<0.05 ; p<0.001)$. Hunger and RQ were lower with HP-OC than HP $(693 \pm 208$ vs. $905 \pm 209 \mathrm{mmVAS} .24 \mathrm{~h}, \mathrm{p}<0.01 ; 0.76 \pm 0.01$ vs. $0.81 \pm 0.02, \mathrm{p}<0.01) ; \mathrm{BHB}$ was higher $(1349 \pm 653$ vs. $332 \pm 102 \mu \mathrm{mol} / \mathrm{l}, \mathrm{p}<0.001)$. $\Delta$ Hunger, $\Delta \mathrm{RQ}$, and $\triangle \mathrm{BHB}$ were larger between HPOC-NP-g than between HP-NP $(-346 \pm 84$ vs. $-107 \pm 52$ mmVAS.24h, $p<0.01 ;-0.09 \pm 0.00$ vs. $-0.05 \pm 0.00, p<0.001 ; 1115 \pm 627$ vs. $104 \pm 42 \mu \mathrm{mol} / \mathrm{l}, \mathrm{p}<0.001)$.

Conclusion: Appetite suppression and fat oxidation are higher at a high protein diet without than with carbohydrates. Energy expenditure is not affected by the carbohydrate content of a high protein diet.

KEYWORDS: appetite, carbohydrates, high protein, energy expenditure, $\beta$ hydroxybutyrate, dietary fat oxidation 


\section{INTRODUCTION}

Two types of high protein diets, i.e. with a normal or a low proportion of carbohydrates, have been shown to be successful for body weight loss and weight maintenance. The proportion of protein in these diets ranged from 20 to 40 percentage of energy (En\%), whereas the proportion of carbohydrates ranged from 4 to $50 \mathrm{En \%}$ (1-19). Diets with less than $38 \mathrm{En} \%$ from carbohydrates have been claimed to be so-called 'low carb' diets and are indicated to be ketogenic $(6-9,11-16,18,19)$. However, in order to be effectively ketogenic, a diet should contain less than 20 gram or, depending on energy intake, only 2-6 En\% from carbohydrates (20, 21). These high protein, low carbohydrate diets also contain a relatively high proportion of fat and are often referred to as 'Atkins' diets $(7,8,16)$.

Many favourable results have been published with respect to body weight loss after 'Atkins' diets, i.e. weight losses of 4.5 to $12.0 \mathrm{~kg}$ after 'Atkins' diets with 20 En\% from protein and 5-8 En\% from carbohydrates compared with 2.5 to $6.5 \mathrm{~kg}$ after control diets with $15 \mathrm{En} \%$ from protein and 50-55 En\% from carbohydrates in 2 to 6 months $(8,13-16)$. Moreover, a large metaanalysis shows that high protein diets that are low in carbohydrate content increase body weight loss compared with control diets (22). After diets relatively high in protein but with normal carbohydrate content (25-30 En\% from protein and 45-50 En\% from carbohydrates) body weight loss ranged from 4.9 to $8.9 \mathrm{~kg}$ compared with 3.4 to $6.9 \mathrm{~kg}$ after control diets with 15 En\% from protein and $\sim 60 \mathrm{En} \%$ from carbohydrates in 2 to 6 months $(1,2,4,17)$. Additionally, Johnstone et al. showed that weight loss was larger after a high protein, low carbohydrate diet (30/4/66 En\% protein/carbohydrate/fat) than after a high protein, normal carbohydrate diet (30/35/35 En\% protein/carbohydrate/fat) for 4 weeks (6.34 vs. $4.35 \mathrm{~kg}$ ) (6). Thus, high protein, low carbohydrate diets may be more effective in reducing body weight up to 6 months than high protein diets with normal carbohydrate content. Despite the effectiveness for reducing body weight, possible other effects of these diets have been under debate and the significance of these effects remains to be elucidated (23-25).

The metabolic targets that are suggested to be affected in the above mentioned long term studies are suppression of appetite, increase in energy expenditure, and/or increase of fat oxidation (1-19). Although high protein diets in general have been shown to affect appetite suppression, energy expenditure, fat oxidation, and sparing of fat-free mass (26-28), effects of high protein diets with or without a normal proportion of carbohydrates on these metabolic targets have not been compared under controlled conditions. Therefore, it is not known which of these metabolic targets are especially affected by the absence of carbohydrates in a high protein diet. The research question of the present study is to assess the significance of the presence or absence of a normal proportion of carbohydrates in a relatively high protein diet for affecting appetite suppression, energy expenditure, and fat oxidation, measured in a controlled setting in a respiration chamber with subjects in energy balance. 


\section{SUBJECTS AND METHODS}

\section{Subjects}

Forty-five healthy volunteers (20 men and 25 women, Body Mass Index (BMI): $18.5-25 \mathrm{~kg} / \mathrm{m}^{2}$, age: $18-40$ y) were recruited by advertisements placed on notice boards at the university. All subjects underwent a medical screening procedure and were in good health, non-smokers, not using medication and at most moderate alcohol users ( $\leq 10$ alcoholic consumptions per week). After medical screening subjects were stratified in two groups based on gender, age, and BMI; there were no differences between the groups (table 1). Written informed consent was obtained from all participants. The study was approved by the Medical Ethics Committee of the Maastricht University Medical Center and was conducted from January 2006 till December 2008.

\section{Experimental sessions}

\section{Protocol}

In both groups subjects were offered two different diets while staying in a respiration chamber for 36 hours (20.00h day 1 till $08.00 \mathrm{~h}$ day 3 ). The sessions were conducted four weeks apart to preclude influences of the menstrual cycle. Group 1 received a high protein diet and a normal protein diet (HP and NP) in a single-blind, randomized, crossover design. Group 2 received a high protein, carbohydrate-free diet and a normal protein diet (HP-OC and NP-g) in a single-blind, randomized, cross-over design, both preceded by a glycogen-lowering exercise test that took place at $17.00 \mathrm{~h}$ on day 1 , in order to mimic the long term effects of a low carbohydrate diet that depletes glycogen stores to a great extent (29). This glycogen-lowering exercise test has been shown before not to affect energy expenditure nor respiratory quotient (30).

A fasting blood sample was taken at the end of each session to measure the concentration of $\beta$ hydroxybutyrate in plasma $(08.00 \mathrm{~h}$ day 3 ). Ketone bodies, of which $\beta$-hydroxybutyrate is the most important in the blood, are produced when whole-body metabolism shifts towards obtaining a greater percentage of energy from lipid sources when carbohydrate availability is low (20).

At the first experimental session body composition was determined.

Table 1 Subject characteristics of the subjects stratified in group 1 (NP + HP diet) and group 2 (NP-g + HP-OC diet)

Group 1

$(n=22)$

Male/Female

Age (years)

Height $(\mathrm{m})$

Weight ( $\mathrm{kg})$

BMI $\left(\mathrm{kg} / \mathrm{m}^{2}\right)$

Body fat (\%)
$10 / 12$
$23 \pm 3$
$1.75 \pm 0.08$
$66.9 \pm 8.3$
$21.7 \pm 1.5$
$20.3 \pm 3.1$

Group 2

$(n=23)$

$10 / 13$

$23 \pm 2$

$1.74 \pm 0.08$

$67.1 \pm 10.3$

$22.2 \pm 2.3$

$22.9 \pm 6.7$

Values are expressed as mean \pm stdev

No differences between the two groups 


\section{Diets and energy intake}

Group 1 received a diet with 30/40/30 En\% from protein(P)/carbohydrate(CHO)/fat(F) (HP) and a diet with 10/60/30 En\% from P/CHO/F (NP). Here, the effects of a relatively high and normal proportion of protein were compared while fat was kept constant and the proportion of carbohydrates was within the normal range of 40 to $60 \mathrm{En} \%$. Group 2 received a diet with 30/0/70 En\% from P/CHO/F (HP-OC) and a diet with 10/60/30 En\% from P/CHO/F (NP-g). The proportion of protein was the same as in the diets of group 1, however, the HP-OC diet did not contain any carbohydrates. Subjects performed a glycogen-lowering exercise test.

Subjects were fed with a study diet designed to provide energy balance. For the meals subjects consumed before the experimental sessions at home, the energy content was based on basal metabolic rate (BMR) which was calculated with the equation of Harris-Benedict and multiplied with an activity index of $1.7(31,32)$. A detailed composition of the diets is presented in table 2 . In order to reach the required macronutrient compositions, amounts of the foods to be served were calculated accordingly. During the screening visit it was tested whether the subjects liked all food items sufficiently. Dietary fibre intake was $18.6 \pm 3.1,20.4 \pm 2.9,6.1 \pm 1.8,20.4 \pm 2.9 \mathrm{~g} / \mathrm{d}$ in the HP, NP, HP-OC, and the NP-g condition, respectively.

To determine the appropriate level of energy intake for attaining energy balance in the respiration chamber, the sleeping metabolic rate (SMR) was measured during the first night of the first experimental session and multiplied by an activity index of 1.4. Energy intake was divided over the meals as $20 \%$ for breakfast $(08.00 \mathrm{~h}), 40 \%$ for lunch $(13.00 \mathrm{~h})$, and $40 \%$ for dinner (18.00h).

\section{Glycogen-lowering exercise test}

Before the HP-OC and the NP-g diet subjects performed a glycogen-lowering exercise test on an electronically braked cycle ergometer (Lode Excalibur, Groningen, The Netherlands) in the afternoon of day 1 . Before, at the screening visit, subjects performed an incremental exhaustive exercise test according to the protocol of Kuipers et al. on an electronically braked cycle ergometer to determine maximal power output $\left(W_{\max }\right)(33)$, which was $258 \pm 50$ Watt. After a warming-up at $50 \%$ of their $W_{\max }$ for 5 minutes, subjects cycled for 2 minutes at $90 \%$ of their $W_{\max }$ followed by 2 minutes at $50 \%$ of their $W_{\max }$, this was repeated until subjects were no longer able to maintain the high intensity exercise. The maximal intensity was then lowered to $80 \%$ of $W_{\max }$. When this intensity also could no longer be maintained, the maximal intensity was decreased to $70 \%$ of $W_{\max }$. The test was ended after exhaustion (30). Subjects were allowed to consume water during the exercise test. Heart rate was monitored continuously during the exercise with a Polar Sport tester (Polar, Kempele, Finland).

\section{Appetite profile}

Appetite profile was measured using $100 \mathrm{~mm}$ Visual Analogue Scales (VAS), with the questions "How hungry are you?" and "How satiated do you feel?" that were anchored with 'not at all' and 'extremely'. Subjects were instructed to rate themselves by marking the scale at the point that was most appropriate to their feeling at that time. Questionnaires were completed during each experimental session at $7.55 \mathrm{~h}, 8.30 \mathrm{~h}, 9.00 \mathrm{~h}, 9.30 \mathrm{~h}, 10.00 \mathrm{~h}, 11.00 \mathrm{~h}, 12.00 \mathrm{~h}, 12.55 \mathrm{~h}, 13.30 \mathrm{~h}$, $14.00 \mathrm{~h}, 14.30 \mathrm{~h}, 15.00 \mathrm{~h}, 16.00 \mathrm{~h}, 17.00 \mathrm{~h}, 17.55 \mathrm{~h}, 18.30 \mathrm{~h}, 19.00 \mathrm{~h}, 19.30 \mathrm{~h}, 20.00 \mathrm{~h}, 21.00 \mathrm{~h}, 22.00 \mathrm{~h}$ on day 2 . For the calculation of the $24 \mathrm{~h}$ area under the curve (AUC) the VAS ratings were 
interpolated from the latest measurement at night until the first measurement in the morning (34).

Table 2 Composition of the meals in the normal protein (NP), high protein (HP), normal protein (NP-g), and the high protein, carbohydrate-free (HP-OC) diet

\begin{tabular}{|c|c|c|c|c|}
\hline & NP & HP & NP-g & $\mathrm{HP}-\mathrm{OC}$ \\
\hline Breakfast & $\begin{array}{l}\text { whole wheat bread } \\
\text { low-fat margarine } \\
\text { chocolate spread } \\
\text { confiture } \\
\text { coffee (decaffeinated)/tea }\end{array}$ & $\begin{array}{l}\text { whole wheat bread } \\
\text { low-fat margarine } \\
\text { chicken filet } \\
\text { milk } \\
\text { meringue }\end{array}$ & $\begin{array}{l}\text { whole wheat bread } \\
\text { low-fat margarine } \\
\text { chocolate spread } \\
\text { confiture } \\
\text { coffee (decaffeinated)/tea }\end{array}$ & $\begin{array}{l}\text { boiled eggs } \\
\text { bacon } \\
\text { coffee (decaffeinated)/tea }\end{array}$ \\
\hline Lunch & $\begin{array}{l}\text { soup } \\
\text { whole wheat bread } \\
\text { low-fat margarine } \\
\text { chocolate spread } \\
\text { cheese } \\
\text { lettuce } \\
\text { cucumber } \\
\text { olive oil } \\
\text { grape juice }\end{array}$ & $\begin{array}{l}\text { whole wheat bread } \\
\text { soy milk } \\
\text { tomato } \\
\text { cucumber } \\
\text { feta cheese } \\
\text { salad dressing } \\
\text { tuna in water } \\
\text { fruit yoghurt }\end{array}$ & $\begin{array}{l}\text { soup } \\
\text { whole wheat bread } \\
\text { low-fat margarine } \\
\text { chocolate spread } \\
\text { cheese } \\
\text { lettuce } \\
\text { cucumber } \\
\text { olive oil } \\
\text { grape juice }\end{array}$ & $\begin{array}{l}\text { soup } \\
\text { salami } \\
\text { tuna in oil } \\
\text { garden cress } \\
\text { french cheese } \\
\text { lettuce } \\
\text { mushrooms } \\
\text { olive oil } \\
\text { sugar-free syrup }\end{array}$ \\
\hline Dinner & $\begin{array}{l}\text { soup } \\
\text { Chinese noodle dish } \\
\text { cucumber } \\
\text { olive oil } \\
\text { fruit cocktail } \\
\text { grape juice }\end{array}$ & $\begin{array}{l}\text { soup } \\
\text { rice dish with ham } \\
\text { soy milk } \\
\text { muesli bar }\end{array}$ & $\begin{array}{l}\text { soup } \\
\text { Chinese noodle dish } \\
\text { cucumber } \\
\text { olive oil } \\
\text { fruit cocktail } \\
\text { grape juice }\end{array}$ & $\begin{array}{l}\text { soup } \\
\text { chicken meat } \\
\text { tuna in oil } \\
\text { garden cress } \\
\text { cheese } \\
\text { lettuce } \\
\text { mushrooms } \\
\text { olive oil } \\
\text { sugar-free syrup }\end{array}$ \\
\hline
\end{tabular}

Macronutrient composition NP: 10/60/30, HP: 30/40/30, NP-g: 10/60/30, and HP-0C: $30 / 0 / 70 \%$ of energy from protein/carbohydrate/fat

\section{Energy expenditure and substrate oxidation}

Oxygen consumption and carbon dioxide production were measured in the respiration chamber (35). This is a $14 \mathrm{~m}^{3}$ room furnished with a bed, chair, computer, television, dvd player, telephone, intercom, sink, and toilet. The room was ventilated with fresh air at a rate of 70-80 $1 /$ minute. The ventilation rate was measured using electronically modified dry gas meters (G6, Schlumberger, Dordrecht, The Netherlands). The analysis system consisted of dual pairs of infrared $\mathrm{CO}_{2}$ (ABB/Hartman\&Braun Uras, Frankfurt a.M., Germany) and paramagnetic $\mathrm{O}_{2}$ analyzers (Servomex 4100, Crowborough, United Kingdom). Data-acquisition was performed using custom built interfaces (IDEE Maastricht University, Maastricht, The Netherlands), a computer (Apple Macintosh, Cupertino, USA), and graphical programming environment (Labview, National Instruments, Austin, USA). 
Energy expenditure and carbohydrate, fat, and protein oxidation were calculated from the measurements of $\mathrm{O}_{2}$ consumption, $\mathrm{CO}_{2}$ production, and urinary nitrogen excretion, using the formula of Brouwer (36). Energy expenditure and 24h respiratory quotient (RQ) were measured from $08.00 \mathrm{~h}$ on day 2 till $07.30 \mathrm{~h}$ on day 3. SMR was defined as the lowest mean energy expenditure measured over three consecutive hours between $00.00 \mathrm{~h}$ and $06.00 \mathrm{~h}$. From the second voiding on day 2 until the first voiding on day $324 \mathrm{~h}$ urine was collected. Samples were collected in containers with $10 \mathrm{ml} \mathrm{H}_{2} \mathrm{SO}_{4}$ to prevent nitrogen loss through evaporation. Volume and nitrogen concentration were measured, the latter using a nitrogen analyzer (Elemental Analyzer, CHN-O-Rapid, Heraeus, Wellesley, USA).

\section{6-Hydroxybutyrate}

A blood sample was obtained after an overnight fast at $8.00 \mathrm{~h}$ on day 3 and mixed in an EDTA tube, centrifuged at $4^{\circ} \mathrm{C}$ for 10 minutes at $3000 \mathrm{rpm}$. Plasma was stored at $-80^{\circ} \mathrm{C}$ until analysis. The $\beta$-hydroxybutyrate concentration was measured with the method of Moore et al. using a semiautomated centrifugal spectrophotometer (Cobas Fara, Roche Diagnostics, Basel, Switzerland) (37).

\section{Body composition}

Body composition was determined by the three compartment model, using the hydrodensitometry and deuterium dilution $\left({ }^{2} \mathrm{H}_{2} \mathrm{O}\right)$ technique $(38,39)$ and was calculated using the combined equation of Siri (40).

\section{Statistical analysis}

Data are presented as mean \pm standard deviation. An ANOVA repeated measures was used to determine possible differences in appetite, energy expenditure, $R Q$, and $\beta$-hydroxybutyrate concentration between the HP and the NP diet and between the HP-OC and the NP-g diet, respectively. A Mann-Whitney $U$ test was used to determine differences in appetite, energy expenditure, $R Q$, and $\beta$-hydroxybutyrate concentration between the NP-g and the NP diet and between the HP-OC and the HP diet, respectively. In addition, a Mann-Whitney $U$ test was used to determine differences in the $\Delta$ between the HP and the NP diet and the $\Delta$ between the HP-OC and the NP-g diet in appetite, energy expenditure, $R Q$, and $\beta$-hydroxybutyrate concentration. $A$ $p$-value $<0.05$ was regarded as statistically significant. Statistical procedures were performed using StatView 5.0 (SAS Institute Inc., 1998, USA).

\section{RESULTS}

There were no differences between the NP diet and the NP-g diet in appetite profile, energy expenditure, respiratory quotient, or $\beta$-hydroxybutyrate concentration (table 3 ). Thus, the glycogen-lowering exercise test did not affect these parameters. 


\section{Appetite profile}

Hunger was $10 \%$ lower after the HP diet than after the NP diet $(p<0.05$, table 3$)$ and was $33 \%$ lower after the HP-OC diet than after the NP-g diet $(p<0.001)$. There was no difference in hunger between the NP-g and the NP diet, whereas hunger was $27 \%$ lower after the HP-OC diet than after the HP diet ( $z$-score: $4.1, p<0.01$ ). The $\triangle$ hunger between the HP-OC and the NP-g diet was larger than the $\triangle$ hunger between the HP and the NP diet ( $z$-score: $5.1, p<0.01$ ).

Satiety was $21 \%$ higher after the HP diet than after the NP diet $(p<0.05)$ and was $28 \%$ higher after the HP-OC diet than after the NP-g diet $(p<0.001)$. There was no difference in satiety between the NP-g and the NP diet nor between the HP-OC and the HP diet. The $\Delta$ satiety between the HP-OC and the NP-g diet was higher than the $\triangle$ satiety between the HP and the NP diet (z-score: 5.1, $p<0.01)$.

\section{Energy expenditure}

Energy expenditure was $4 \%$ higher after the HP diet than after the NP diet $(p<0.05$, table 3$)$ and tended to be higher after the HP-OC diet than after the NP-g diet $(p=0.07)$. There was no difference in energy expenditure between the NP-g and the NP diet nor between the HP-OC and the HP diet. The $\triangle$ energy expenditure between the HP-OC and the NP-g diet was not different from the $\Delta$ energy expenditure between the HP and the NP diet.

Energy balance was not different from zero after the HP diet, whereas the subjects were slightly in positive energy balance after the NP diet $(p<0.05)$. Energy balance was not different from zero both after the HP-OC diet and the NP-g diet. The energy balance was not different between the NP-g diet and the NP diet nor between the HP-OC diet and the HP diet.

\section{Respiratory quotient}

The RQ was lower after the HP diet than after the NP diet ( $p<0.01$, table 3$)$ and was lower after the HP-OC diet than after the NP-g diet $(p<0.001)$. There was no difference in RQ between the NP-g and the NP diet whereas the RQ was lower after the HP-OC diet than after the HP diet (zscore: $4.9, p<0.01)$. The $\triangle R Q$ between the HP-OC and the NP-g diet was larger than the $\triangle R Q$ between the HP and the NP diet (z-score: 5.3, p<0.001).

\section{B-Hydroxybutyrate}

The $\beta$-hydroxybutyrate concentration was higher after the HP diet than after the NP diet $(p<0.05$, table 3$)$ and was higher after the HP-OC diet than after the NP-g diet $(p<0.001)$. There was no difference in $\beta$-hydroxybutyrate concentration between the NP-g and the NP diet, whereas the $\beta$-hydroxybutyrate concentration was higher after the HP-OC diet than after the HP diet ( $z$-score: $5.8, \mathrm{p}<0.001$ ). The $\Delta \beta$-hydroxybutyrate concentration between the HP-OC and the NP-g diet was larger than the $\Delta \beta$-hydroxybutyrate concentration between the HP and the NP diet (z-score: 5.3, p<0.001). 


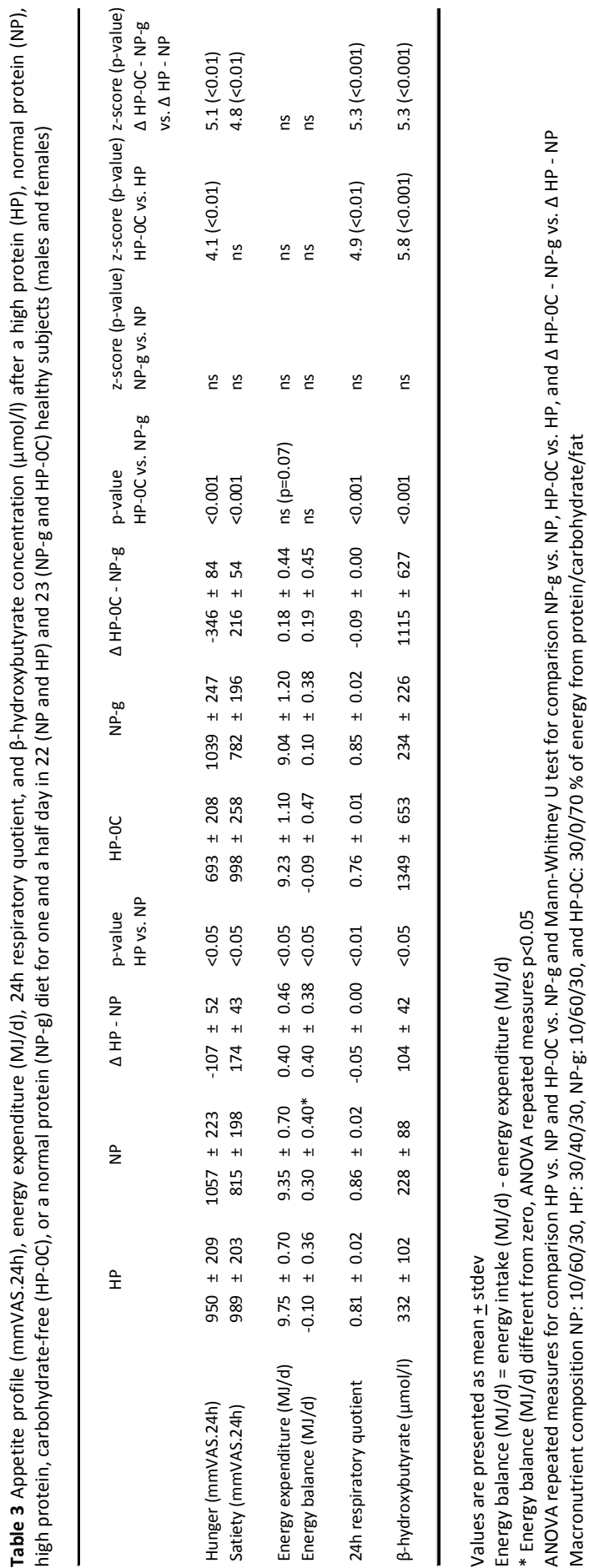




\section{DISCUSSION}

The presence or absence of a normal proportion of carbohydrates in a relatively high protein diet significantly affected the metabolic targets appetite suppression and fat oxidation in healthy normal weight subjects who were in energy balance and were studied under highly controlled conditions. There we no differences between the NP diet and the NP-g diet, thus the glycogenlowering exercise did not affect appetite, energy expenditure, or respiratory quotient.

Suppression of appetite was clearly affected by the absence of a normal proportion of carbohydrates in a high protein diet. Coinciding with the reduced appetite there was an increased dietary fat oxidation, reflected by the lower respiratory quotient. Dietary fat oxidation was increased at a high protein, normal carbohydrate diet $(30 / 40 / 30$ En\% protein/carbohydrate/fat) compared with a normal diet with 30-35 En\% from fat (and $10 \mathrm{En} \%$ from protein) (41) and was even more increased when subjects were on a high protein, carbohydrate-free diet (30/0/70 En\% protein/carbohydrate/fat). Inhibition of dietary fat oxidation has been shown to increase food intake $(42,43)$, whereas increased fatty acid oxidation is suggested to reduce appetite (44-46). This may be due to stimulation of carnitine palmitoyl transferase-1 (CPT-1), a catalyst of the rate-limiting step in mitochondrial fatty acid oxidation, which has been shown to inhibit eating (44). A greater fat oxidation together with a lower appetite was for instance also observed in humans that consumed diacylglycerols instead of triacylglycerols (47). Increased fat oxidation when carbohydrate availability is low results in the production of ketone bodies, i.e. $\beta$-hydroxybutyrate (20), as was also observed in the present study. $\beta$-Hydroxybutyrate reduced food intake after intracerebroventricular infusion or subcutaneous injection in rats $(48,49)$. Higher $\beta$-hydroxybutyrate concentrations coinciding with reduced appetite have been reported in several studies $(6,46,50,51)$. Taken together, the increased dietary fat oxidation and increase in $\beta$-hydroxybutyrate concentration, i.e. a ketogenic state, is likely to contribute to the appetite suppressive effect of high protein, low carbohydrate diets. The same mechanism may play a role in a high protein, normal carbohydrate diet, but to a much smaller extent.

The present study also clearly shows that the presence or absence of a normal proportion of carbohydrates in a relatively high protein diet does not affect energy expenditure differently. Therefore, the increase in energy expenditure that has been observed with high protein diets (26-28) is mainly due to the relatively high proportion of protein and not the presence or absence of a normal proportion of carbohydrates.

The effects of the high protein diets with or without a normal proportion of carbohydrates were compared using two groups of subjects, without significant differences in subject characteristics. The glycogen-lowering exercise performed by the subjects in group 2 and not by those in group 1 is unlikely to have affected appetite, energy expenditure, respiratory quotient, or $\beta$ hydroxybutyrate concentration. These parameters were not different between the NP and the NP-g diet, suggesting no effect of the glycogen-lowering exercise, similar to previous studies (30). The exercise intended to mimic the long term effect of a low carbohydrate diet on body glycogen stores in the high protein, carbohydrate-free condition. This appears to be effective since the respiratory quotient was decreased dramatically, indicating a relatively high fat 
oxidation. Other than this effect in the high protein, carbohydrate-free condition, the exercise did not affect energy expenditure or substrate oxidation differently.

The dietary fibre content was not the same in all 4 diets, which may have affected metabolic targets. Although there were no differences between the HP, NP, and NP-g diet, the fibre content of the HP-OC diet was significantly lower than that of the other diets. Raben et al. showed that a high fibre meal decreased diet-induced thermogenesis and fat oxidation and increased fullness (52). However, in the study of Raben et al. the relative fibre content was much higher than in the present study (4.7 g/MJ vs. $\sim 2 \mathrm{~g} / \mathrm{MJ})(52)$. Moreover, if the higher fibre content indeed increased fullness, the appetite suppressive effect of the HP-OC diet was even more pronounced since fibre content was lower in HP-OC diet. The increased appetite suppression and fat oxidation after the high protein, carbohydrate-free diet thus are not attributable to the lower fibre content of the diet.

In conclusion, the presence or absence of a normal proportion of carbohydrates in a relatively high protein diet significantly affects the metabolic targets appetite suppression and fat oxidation. An increased dietary fat oxidation and the concentration of $\beta$-hydroxybutyrate, i.e. a ketogenic state, may contribute to the increased appetite suppression on a high protein, low carbohydrate diet. Energy expenditure is not affected differently by the presence or absence of a normal proportion of carbohydrates in a high protein diet.

\section{ACKNOWLEDGEMENTS}

MABV, KRW, and MSW-P designed research. MABV and MSW-P collected and analyzed the data. MABV wrote the manuscript and KRW, JAHvV, and MSW-P contributed to the interpretation of the data and reviewed the manuscript.

\section{REFERENCES}

1. Layman DK, Boileau RA, Erickson DJ, et al. A reduced ratio of dietary carbohydrate to protein improves body composition and blood lipid profiles during weight loss in adult women. J Nutr 2003;133:411-7.

2. Weigle DS, Breen PA, Matthys CC, et al. A high-protein diet induces sustained reductions in appetite, ad libitum caloric intake, and body weight despite compensatory changes in diurnal plasma leptin and ghrelin concentrations. Am J Clin Nutr 2005;82:41-8.

3. Westerterp-Plantenga MS, Lejeune MP, Nijs I, van Ooijen M, Kovacs EM. High protein intake sustains weight maintenance after body weight loss in humans. Int J Obes Relat Metab Disord 2004;28:57-64.

4. Skov AR, Toubro S, Ronn B, Holm L, Astrup A. Randomized trial on protein vs carbohydrate in ad libitum fat reduced diet for the treatment of obesity. Int J Obes Relat Metab Disord 1999;23:528-36.

5. Due A, Toubro S, Skov AR, Astrup A. Effect of normal-fat diets, either medium or high in protein, on body weight in overweight subjects: a randomised 1-year trial. Int J Obes Relat Metab Disord 2004;28:1283-90.

6. Johnstone AM, Horgan GW, Murison SD, Bremner DM, Lobley GE. Effects of a high-protein ketogenic diet on hunger, appetite, and weight loss in obese men feeding ad libitum. Am J Clin Nutr 2008;87:44-55.

7. Johnston CS, Tjonn SL, Swan PD, White A, Hutchins H, Sears B. Ketogenic low-carbohydrate diets have no metabolic advantage over nonketogenic low-carbohydrate diets. Am J Clin Nutr 2006;83:1055-61.

8. Foster GD, Wyatt HR, Hill JO, et al. A randomized trial of a low-carbohydrate diet for obesity. N Engl J Med 2003;348:2082-90.

9. Volek J, Sharman M, Gomez A, et al. Comparison of energy-restricted very low-carbohydrate and low-fat diets on weight loss and body composition in overweight men and women. Nutr Metab (Lond) 2004;1:13.

10. Pichon L, Potier M, Tome D, et al. High-protein diets containing different milk protein fractions differently influence energy intake and adiposity in the rat. Br J Nutr 2007:1-10. 
11. Brehm BJ, Seeley RJ, Daniels SR, D'Alessio DA. A randomized trial comparing a very low carbohydrate diet and a calorie-restricted low fat diet on body weight and cardiovascular risk factors in healthy women. J Clin Endocrinol Metab 2003;88:1617-23.

12. Samaha FF, Iqbal N, Seshadri P, et al. A low-carbohydrate as compared with a low-fat diet in severe obesity. N Engl J Med 2003;348:2074-81.

13. Yancy WS, Jr., Olsen MK, Guyton JR, Bakst RP, Westman EC. A low-carbohydrate, ketogenic diet versus a low-fat diet to treat obesity and hyperlipidemia: a randomized, controlled trial. Ann Intern Med 2004;140:769-77.

14. Shai I, Schwarzfuchs D, Henkin Y, et al. Weight loss with a low-carbohydrate, Mediterranean, or low-fat diet. N Engl J Med 2008;359:229-41.

15. Westman EC, Yancy WS, Edman JS, Tomlin KF, Perkins CE. Effect of 6-month adherence to a very low carbohydrate diet program. Am J Med 2002;113:30-6.

16. Gardner CD, Kiazand A, Alhassan S, et al. Comparison of the Atkins, Zone, Ornish, and LEARN diets for change in weight and related risk factors among overweight premenopausal women: the A TO Z Weight Loss Study: a randomized trial. Jama 2007;297:969-77.

17. Noakes M, Keogh JB, Foster PR, Clifton PM. Effect of an energy-restricted, high-protein, low-fat diet relative to a conventional high-carbohydrate, low-fat diet on weight loss, body composition, nutritional status, and markers of cardiovascular health in obese women. Am J Clin Nutr 2005;81:1298-306.

18. Meckling KA, O'Sullivan C, Saari D. Comparison of a low-fat diet to a low-carbohydrate diet on weight loss, body composition, and risk factors for diabetes and cardiovascular disease in free-living, overweight men and women. J Clin Endocrinol Metab 2004;89:2717-23.

19.

Stern L, Iqbal N, Seshadri P, et al. The effects of low-carbohydrate versus conventional weight loss diets in severely obese adults: one-year follow-up of a randomized trial. Ann Intern Med 2004;140:778-85.

20. Robinson AM, Williamson DH. Physiological roles of ketone bodies as substrates and signals in mammalian tissues. Physiol Rev 1980;60:143-87.

21. Volek JS, Westman EC. Very-low-carbohydrate weight-loss diets revisited. Cleve Clin J Med 2002;69:849, 853, 856-8 passim.

22. Krieger JW, Sitren HS, Daniels MJ, Langkamp-Henken B. Effects of variation in protein and carbohydrate intake on body mass and composition during energy restriction: a meta-regression 1. Am J Clin Nutr 2006;83:260-74.

23.

24.

25.

26. Westerterp-Plantenga MS, Luscombe-Marsh N, Lejeune MP, et al. Dietary protein, metabolism, and bodyAstrup A, Hill JO Saris WH. Dietary fat: at the heart of the matter. Science 2001:293:801-4.

Bonow RO, Eckel RH. Diet, obesity, and cardiovascular risk. N Engl J Med 2003;348:2057-8.

Blackburn GL, Phillips JC, Morreale S. Physician's guide to popular low-carbohydrate weight-loss diets. Cleve Clin J Med 2001;68:761, 765-6, 768-9, 773-4. weight regulation: dose-response effects. Int J Obes (Lond) 2006;30 Suppl 3:S16-23.

27. Eisenstein J, Roberts SB, Dallal G, Saltzman E. High-protein weight-loss diets: are they safe and do they work? A review of the experimental and epidemiologic data. Nutr Rev 2002;60:189-200.

28. Brehm BJ, D'Alessio DA. Benefits of high-protein weight loss diets: enough evidence for practice? Curr Opin Endocrinol Diabetes Obes 2008;15:416-21.

29. Westman EC, Feinman RD, Mavropoulos JC, et al. Low-carbohydrate nutrition and metabolism. Am J Clin Nutr 2007;86:276-84.

30. Schrauwen P, van Marken Lichtenbelt WD, Saris WH, Westerterp KR. Role of glycogen-lowering exercise in the change of fat oxidation in response to a high-fat diet. Am J Physiol 1997;273:E623-9.

31. Harris JA, Benedict FG. A biometric study of basal metabolism in man. Proc Natl Acad Sci 1918;4:370-373.

32. Westerterp KR. Exercise and energy balance. In: M.S. Westerterp-Plantenga ABS, A. Tremblay, ed. Regulation of food intake and energy expenditure: EDRA, 1999:349-361.

33. Kuipers H, Keizer HA, Brouns F, Saris WH. Carbohydrate feeding and glycogen synthesis during exercise in man. Pflugers Arch 1987;410:652-6.

34. Westerterp-Plantenga MS, Rolland V, Wilson SA, Westerterp KR. Satiety related to $24 \mathrm{~h}$ diet-induced thermogenesis during high protein/carbohydrate vs high fat diets measured in a respiration chamber. Eur J Clin Nutr 1999;53:495-502.

35. Schoffelen PF, Westerterp KR, Saris WH, Ten Hoor F. A dual-respiration chamber system with automated calibration. J Appl Physiol 1997;83:2064-72.

36.

Brouwer E. On simple formulae for calculating the heat expenditure and the quantities of carbohydrate and fat oxidized in metabolism of men and animals, from gaseous exchange (Oxygen intake and carbonic acid output) and urine-N. Acta Physiol Pharmacol Neerl 1957;6:795-802.

37. Moore JJ, Marcus M, Sax SM. Kinetic assay of beta-hydroxybutyrate in plasma with a COBAS-BIO centrifugal analyzer. Clin Chem 1982;28:702-3.

38. van Marken Lichtenbelt WD, Westerterp KR, Wouters L. Deuterium dilution as a method for determining total body water: effect of test protocol and sampling time. Br J Nutr 1994;72:491-7.

39. Schoeller DA, van Santen E, Peterson DW, Dietz W, Jaspan J, Klein PD. Total body water measurement in humans with 180 and $2 \mathrm{H}$ labeled water. Am J Clin Nutr 1980;33:2686-93.

40. Siri WE. Body composition from fluid spaces and density: analysis of methods. 1961. Nutrition 1993;9:480-91; discussion 480, 492. 
41. Westerterp KR, Smeets A, Lejeune MP, Wouters-Adriaens MP, Westerterp-Plantenga MS. Dietary fat oxidation as a function of body fat. Am J Clin Nutr 2008;87:132-5.

42. Kahler A, Zimmermann M, Langhans W. Suppression of hepatic fatty acid oxidation and food intake in men. Nutrition 1999;15:819-28.

43. Scharrer E, Langhans W. Control of food intake by fatty acid oxidation. Am J Physiol 1986;250:R1003-6.

44. Langhans W. Fatty acid oxidation in the energostatic control of eating--a new idea. Appetite 2008;51:446-51.

45. Leonhardt M, Langhans W. Fatty acid oxidation and control of food intake. Physiol Behav 2004;83:645-51.

46. Scharrer E. Control of food intake by fatty acid oxidation and ketogenesis. Nutrition 1999;15:704-14.

47. Kamphuis MM, Mela DJ, Westerterp-Plantenga MS. Diacylglycerols affect substrate oxidation and appetite in humans. Am J Clin Nutr 2003;77:1133-9.

48. Arase K, Fisler JS, Shargill NS, York DA, Bray GA. Intracerebroventricular infusions of 3-OHB and insulin in a rat model of dietary obesity. Am J Physiol 1988;255:R974-81.

49. Fisler JS, Egawa M, Bray GA. Peripheral 3-hydroxybutyrate and food intake in a model of dietary-fat induced obesity: effect of vagotomy. Physiol Behav 1995;58:1-7.

50. Krotkiewski M. Value of VLCD supplementation with medium chain triglycerides. Int J Obes Relat Metab Disord 2001;25:1393-400.

51. Meckling KA, Gauthier M, Grubb R, Sanford J. Effects of a hypocaloric, low-carbohydrate diet on weight loss, blood lipids, blood pressure, glucose tolerance, and body composition in free-living overweight women. Can $\mathrm{J}$ Physiol Pharmacol 2002;80:1095-105.

52. Raben A, Christensen NJ, Madsen J, Holst JJ, Astrup A. Decreased postprandial thermogenesis and fat oxidation but increased fullness after a high-fiber meal compared with a low-fiber meal. Am J Clin Nutr 1994;59:1386-94. 

Chapter 9

\section{Gluconeogenesis and energy expenditure after a high protein, carbohydrate-free diet}

Veldhorst MAB, Westerterp-Plantenga MS, Westerterp KR

Am J Clin Nutr 2009; 90: 519-526 


\section{ABSTRACT}

Background: High protein diets have been shown to increase energy expenditure (EE).

Aim: To study whether a high protein, carbohydrate-free diet increases gluconeogenesis (GNG) and whether this can explain the increase in $\mathrm{EE}$.

Methods: Ten healthy male subjects (mean \pm SEM BMI: $23.0 \pm 0.8 \mathrm{~kg} / \mathrm{m}^{2}$, age: $23 \pm 1$ years) received an iso-energetic high protein, carbohydrate-free $(\mathrm{H}, 30 / 0 / 70 \mathrm{En} \%$ protein/carbohydrate/fat) or a normal diet (N, 12/55/33 En\% P/CHO/F) for one and a half day in a randomized, crossover design while $\mathrm{EE}$ was measured in a respiration chamber. Endogenous glucose production (EGP) and fractional GNG were measured using infusion of $\left[6,6-{ }^{2} \mathrm{H}_{2}\right]$ glucose and ingestion of ${ }^{2} \mathrm{H}_{2} \mathrm{O}$; absolute GNG was calculated by multiplying fractional GNG with EGP. Body glycogen stores were lowered at the start of the intervention with an exhaustive glycogenlowering exercise test.

Results: EGP was lower in $\mathrm{H}$ than in $\mathrm{N}(181 \pm 9 \mathrm{~g} / \mathrm{d}$ vs. $226 \pm 9 \mathrm{~g} / \mathrm{d}, \mathrm{p}<0.001)$ whereas fractional GNG was higher $(0.95 \pm 0.04$ vs. $0.64 \pm 0.03, p<0.001)$ and absolute $G N G$ tended to be higher $(171 \pm 10 \mathrm{~g} / \mathrm{d}$ vs. $145 \pm 10 \mathrm{~g} / \mathrm{d}, \mathrm{p}=0.06)$. EE (resting metabolic rate) was greater in $\mathrm{H}$ compared with $\mathrm{N}(8.46 \pm 0.23 \mathrm{MJ} / \mathrm{d}$ vs. $8.12 \pm 0.31 \mathrm{MJ} / \mathrm{d}, \mathrm{p}<0.05)$. The increase in $E E$ was a function of the increase in GNG $\left(\Delta E E=0.007^{*} \Delta G N G-0.038, r=0.70, R^{2}=0.49, p<0.05\right)$. The contribution of $\Delta G N G$ to $\Delta \mathrm{EE}$ was $42 \%$, the energy costs of GNG were $33 \%$ (95\% Cl: $16,50 \%$ ).

Conclusion: $42 \%$ of the increase in energy expenditure after a high protein, carbohydrate-free diet was explained by the increase in gluconeogenesis. Costs of gluconeogenesis are $33 \%$ of the energy content of the produced glucose.

KEYWORDS: gluconeogenesis, energy expenditure, high protein, carbohydrate-free, glycogen, endogenous glucose production, substrate utilization 


\section{INTRODUCTION}

Gluconeogenesis, i.e. the formation of glucose from non-carbohydrate precursors, remains relatively stable in widely varying metabolic conditions in humans, as was concluded in a recent review by Nuttall et al.. In the overnight postabsorptive state, circulating glucose is derived from endogenous glucose production, which consists of two processes: glycogenolysis, i.e. the release of glucose from stored glycogen, and gluconeogenesis. Thus, a change in glucose production rate in varying metabolic conditions is supposed to be mostly dependent on the rate of glycogenolysis and not gluconeogenesis (1).

However, in rats, gluconeogenesis has been shown to be stimulated when glucose availability was reduced during fasting or with a low or carbohydrate-free diet; moreover, gluconeogenesis was increased by a high protein diet $(2,3)$. Azzout-Marniche et al. showed that an increase in the protein content of the diet in rats changed the activity of the enzymes phosphoenolpyruvate carboxykinase and glucose 6-phosphatase, which suggests that liver gluconeogenesis is stimulated by a high protein diet. In the fed state glucose 6-phosphate was directed towards glycogen synthesis whereas in the fasted state it was converted to glucose and released from the hepatocyte (4).

High protein diets were previously shown to increase energy expenditure in healthy human volunteers (5-11). Gluconeogenesis has been hypothesized to contribute to this increased energy expenditure after a high protein diet $(5,6,9,12)$. Although gluconeogenesis is thought to be relatively stable in humans, a high protein diet, especially in the absence of carbohydrates, may stimulate gluconeogenesis (13). Since gluconeogenesis is an energetically costly pathway of protein metabolism with energy costs that are estimated to amount $20 \%(6,12)$, this process may contribute to an increased energy expenditure after a high protein diet or after a high protein, carbohydrate-free diet.

The objective was to study whether a high protein, carbohydrate-free diet increases gluconeogenesis and whether this can explain the increase in energy expenditure. Therefore, gluconeogenesis and energy expenditure were measured when healthy subjects consumed a high protein, carbohydrate-free diet or a normal protein diet. To obtain the same baseline condition and to contrast the effects of the two diets, body glycogen stores were depleted beforehand by means of an exhaustive glycogen-lowering exercise test. Glucose and insulin concentrations were measured to test whether there was a difference in circulating glucose concentration and whether effects on gluconeogenesis could be mediated by insulin - a known factor to influence gluconeogenesis (14).

\section{SUBJECTS AND METHODS}

\section{Subjects}

Ten healthy male volunteers (Body Mass Index: $23.0 \pm 0.8 \mathrm{~kg} / \mathrm{m}^{2}$, age: $23 \pm 1$ years) were recruited by advertisements placed on notice boards at the university. All subjects underwent a medical screening and all were in good health, nonsmokers, not using medication and at most moderate alcohol users ( $\leq 10$ alcoholic consumptions per week). Characteristics of the subjects 
are presented in table 1. Written informed consent was obtained from all participants. The study was approved by the Medical Ethics Committee of the Maastricht University Medical Center. Subject recruitment started in June 2007 and the study was conducted between September 2007 and July 2008.

Table 1 Subject characteristics of the 10 male subjects

\begin{tabular}{lc}
\hline Age (years) & $23 \pm 1$ \\
Wmax $(\mathrm{W})$ & $294 \pm 14$ \\
Height $(\mathrm{m})$ & $1.81 \pm 0.02$ \\
Weight $(\mathrm{kg})$ & $75.5 \pm 3.2$ \\
BMI $\left(\mathrm{kg} / \mathrm{m}^{2}\right)$ & $23.0 \pm 0.8$ \\
Body fat $(\%)$ & $18.0 \pm 1.7$ \\
& \\
\hline
\end{tabular}

Values are expressed as mean \pm SEM

Wmax: maximal power output

\section{Maximal power output}

After medical screening subjects performed an incremental exhaustive exercise test according to the protocol of Kuipers et al. on an electronically braked cycle ergometer (Lode Excalibur, Groningen, The Netherlands) to determine maximal power output $\left(W_{\max }\right)(15)$. Exercise was performed until voluntary exhaustion or until the subject could no longer maintain a pedal rate of more than $60 \mathrm{rpm}$. Heart rate was measured continuously with a Polar Sport tester (Polar, Kempele, Finland). Subjects started cycling at 100 Watt for 5 minutes. Thereafter, workload was increased with 50 Watt every 2.5 minute. When heart rate exceeded 160 beats per minute, the workload increment was reduced to 25 Watt per 2.5 minute. For each subject $W_{\max }$ was calculated as:

$\mathrm{W}_{\max }=100+\mathrm{a} .50+\mathrm{b} .25+\mathrm{c} .5$

where $a$ is the number of completed steps at 50 Watt, $b$ is the number of completed steps at 25 Watt, and $\mathrm{c}$ is the time of the final uncompleted load increment (to the nearest 0.5 minute).

\section{Study design}

The study had a single-blind, randomized, crossover design. Subjects came for two $36 \mathrm{~h}$ sessions in a respiration chamber to measure energy expenditure and substrate oxidation when subjects were consuming either a high protein, carbohydrate-free $(\mathrm{H})$ or a normal $(\mathrm{N})$ diet. Endogenous glucose production and gluconeogenesis were measured immediately afterwards in the postabsorptive state. On both occasions, after a basal blood sample was taken to determine natural abundance, the session started with an exhaustive glycogen-lowering exercise test based on subject's individual maximal power output $\left(\mathrm{W}_{\max }\right)$ in the afternoon (day 1$)$. After a 1.5-day stay in the respiration chamber, endogenous glucose production and gluconeogenesis were measured in the morning of day 3 . The 2 sessions were conducted 8 weeks apart to preclude influences of enrichment derived from the previous experiment. Figure 1 shows a flow-chart of the experimental session. 
The macronutrient compositions of the $\mathrm{H}$ and $\mathrm{N}$ diets was 30/0/70 and 12/55/33 \% of energy from protein/carbohydrate/fat, respectively. In the $\mathrm{H}$ condition, protein intake was $170 \pm 5 \mathrm{~g} / \mathrm{d}$, carbohydrate intake $2 \pm 0 \mathrm{~g} / \mathrm{d}$, and fat intake was $179 \pm 5 \mathrm{~g} / \mathrm{d}$. Lettuce and mushrooms accounted for a carbohydrate intake of $1.6 \pm 0.0 \mathrm{~g} / \mathrm{d}$. In the $\mathrm{N}$ condition, protein intake was $63 \pm$ $2 \mathrm{~g} / \mathrm{d}$, carbohydrate intake $323 \pm 9 \mathrm{~g} / \mathrm{d}$, and fat intake was $87 \pm 2 \mathrm{~g} / \mathrm{d}$. When expressed per $\mathrm{kg}$ body weight, protein intakes were $2.27 \pm 0.06$ and $0.84 \pm 0.02 \mathrm{~g}$ in the $\mathrm{H}$ and $\mathrm{N}$ condition, respectively.

A detailed composition of the diet is presented in table 2. In order to assure that perceived appeal of all food items was acceptable and similar between subjects it was determined beforehand whether the subjects liked all food items sufficiently. Subjects were provided with a list of all food items that were to be used in the experiments and had to rate the food items. Food items that were not liked sufficiently ( $<60 \mathrm{~mm}$ on a $100 \mathrm{~mm}$ Visual Analogue Scale) were replaced by other sufficiently liked food items. Subjects were instructed that during the experiments all food items that were offered had to be eaten completely. On the days prior to the experiments subjects consumed their habitual diet. The last day before an experimental session, subjects consumed the same diet in both conditions.

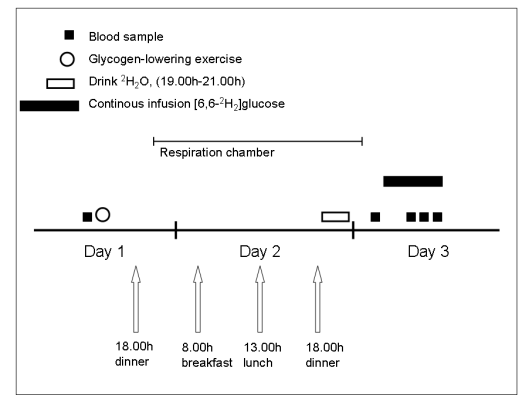

Figure 1 Flow-chart of an experimental session of the study where 10 healthy male subjects received a high protein, carbohydrate-free diet $(\mathrm{H}, 30 / 0 / 70 \%$ of energy from protein/carbohydrate/fat) or a normal protein diet (N, $12 / 55 / 33 \%$ of energy from protein/carbohydrate/fat) for one and a half day in a randomized crossover design. Energy expenditure was measured continuously in a respiration chamber. Body glycogen stores were lowered beforehand by means of an exhaustive glycogen-lowering exercise. Postabsorptive endogenous glucose production and fractional gluconeogenesis were measured using combined infusion of $\left[6,6-{ }^{2} \mathrm{H}_{2}\right]$ glucose and ingestion of ${ }^{2} \mathrm{H}_{2} \mathrm{O}$ 
Table 2 Composition of the meals in the normal protein $\operatorname{diet}(\mathrm{N})$ and in the high protein, carbohydrate-free diet $(\mathrm{H})$

\begin{tabular}{|c|c|c|}
\hline & $\mathrm{N}$ & $\mathrm{H}$ \\
\hline Breakfast & $\begin{array}{l}\text { whole wheat bread } \\
\text { low-fat margarine } \\
\text { chocolate spread } \\
\text { confiture } \\
\text { coffee (decaffeinated)/tea }\end{array}$ & $\begin{array}{l}\text { boiled egg } \\
\text { bacon } \\
\text { coffee (decaffeinated)/tea }\end{array}$ \\
\hline Lunch & $\begin{array}{l}\text { soup } \\
\text { whole wheat bread } \\
\text { low-fat margarine } \\
\text { chocolate spread } \\
\text { cheese } \\
\text { lettuce } \\
\text { cucumber } \\
\text { olive oil } \\
\text { grape juice }\end{array}$ & $\begin{array}{l}\text { soup } \\
\text { salami } \\
\text { tuna } \\
\text { garden cress } \\
\text { french cheese } \\
\text { lettuce } \\
\text { mushrooms } \\
\text { olive oil } \\
\text { sugar-free syrup }\end{array}$ \\
\hline Dinner & $\begin{array}{l}\text { soup } \\
\text { Chinese noodle dish } \\
\text { cucumber } \\
\text { olive oil } \\
\text { mixed fruits } \\
\text { grape juice }\end{array}$ & $\begin{array}{l}\text { soup } \\
\text { chicken meat } \\
\text { tuna } \\
\text { garden cress } \\
\text { cheese } \\
\text { lettuce } \\
\text { mushrooms } \\
\text { olive oil } \\
\text { sugar-free syrup }\end{array}$ \\
\hline
\end{tabular}

Macronutrient composition N: $12 / 55 / 33 \%$ of energy from protein/carbohydrate/fat

Macronutrient composition $\mathrm{H}: 30 / 0 / 70 \%$ of energy from protein/carbohydrate/fat

\section{Energy intake}

During each experimental session subjects were fed in energy balance. The energy content of the first dinner and breakfast of the first experimental session was based on the basal metabolic rate (BMR), as calculated with the equation of Harris and Benedict (16), multiplied by an activity index of 1.35. To determine the appropriate level of energy intake to attain energy balance in the respiration chamber, the sleeping metabolic rate (SMR) was calculated during the first night and multiplied by an activity index of 1.35 . Energy intake was divided over the meals as $20 \%$ for breakfast $(08.00 \mathrm{~h}), 40 \%$ for lunch $(13.00 \mathrm{~h})$, and $40 \%$ for dinner $(18.00 \mathrm{~h})$. Subjects did not eat anymore after dinner on day 2 till the end of the experiment on day 3 .

\section{Glycogen-lowering exercise test}

To lower body glycogen stores, the subjects performed a glycogen-lowering exercise test on an electronically braked cycle ergometer. After warming-up at $50 \%$ of their $\mathrm{W}_{\max }$ for 5 minutes, subjects cycled for 2 minutes at $90 \%$ of their $W_{\max }$ followed by 2 minutes at $50 \%$ of their $W_{\max }$; this was repeated until subjects were no longer able to maintain the high intensity exercise. The maximal intensity was then lowered to $80 \%$ of $\mathrm{W}_{\text {max. }}$. When this intensity also could no longer be 
maintained, the maximal intensity was decreased to $70 \%$ of $\mathrm{W}_{\max }$. The test was ended after exhaustion (17). Subjects were allowed to consume water during the exercise test. Heart rate was monitored continuously during the exercise with a Polar Sport tester.

\section{Indirect calorimetry}

Oxygen consumption and carbon dioxide production were measured in the respiration chamber (18). The respiration chamber is a $14 \mathrm{~m}^{3}$ room furnished with a bed, chair, computer, television, dvd player, telephone, intercom, sink, and toilet. The room was ventilated with fresh air at a rate of 70-80 l/minute. The ventilation rate was measured using electronically modified dry gas meters (G6, Schlumberger, Dordrecht, The Netherlands). The analysis system consisted of dual pairs of infra-red $\mathrm{CO}_{2}$ (ABB/Hartman\&Braun Uras, Frankfurt a.M., Germany) and paramagnetic $\mathrm{O}_{2}$ analyzers (Servomex 4100, Crowborough, United Kingdom). Data-acquisition was performed using custom-built interfaces (IDEE Maastricht University, Maastricht, The Netherlands), a computer (Apple Macintosh, Cupertino, United States of America), and graphical programming environment (Labview, National Instruments, Austin, TX).

\section{Energy expenditure and substrate oxidation}

Energy expenditure and carbohydrate, fat, and protein oxidation were calculated from the measurements of $\mathrm{O}_{2}$ consumption, $\mathrm{CO}_{2}$ production, and urinary nitrogen excretion, using the formula of Brouwer (19). Urinary nitrogen excretion was measured during two 12 hour periods; from $07.00 \mathrm{~h}$ day 2 till $19.00 \mathrm{~h}$ day 2 and from $19.00 \mathrm{~h}$ day 2 till $07.00 \mathrm{~h}$ day 3 . Samples were collected in containers with $10 \mathrm{ml} \mathrm{H}_{2} \mathrm{SO}_{4}$ to prevent nitrogen loss through evaporation. Volume and nitrogen concentration were measured, the latter using a nitrogen analyzer (Elemental Analyzer, CHN-O-Rapid, Heraeus, Wellesley, MA).

The 24h energy expenditure (total energy expenditure, TEE) consists of SMR, diet-induced thermogenesis (DIT), and activity-induced energy expenditure (AEE). Energy expenditure and $24 \mathrm{~h}$ respiratory quotient $(\mathrm{RQ})$ were measured from $07.00 \mathrm{~h}$ on day 2 till $06.30 \mathrm{~h}$ on day 3 . Activity was monitored using a radar system which is based on the Doppler principle. SMR was defined as the lowest mean energy expenditure measured over 3 consecutive hours between $00.00 \mathrm{~h}$ and 06.00h. Resting metabolic rate (RMR) was calculated by plotting energy expenditure against radar output. The intercept of the regression line at the lowest radar output represents the energy expenditure in the inactive state (RMR), consisting of SMR and DIT (11). DIT was calculated by subtracting SMR from RMR. AEE was calculated by subtracting SMR and DIT from $24 \mathrm{~h}$ energy expenditure. Physical activity level (PAL) was calculated by dividing TEE by SMR, energy balance was calculated by subtracting energy expenditure from energy intake.

\section{Body composition}

Body composition was determined with a 3 compartment model, using the hydrodensitometry and deuterium dilution $\left({ }^{2} \mathrm{H}_{2} \mathrm{O}\right)$ technique $(20,21)$ and was calculated by using the combined equation of Siri (22). 


\section{Endogenous glucose production and fractional gluconeogenesis}

Infusion of $\left[6,6-{ }^{2} \mathrm{H}_{2}\right]$ glucose and ingestion of ${ }^{2} \mathrm{H}_{2} \mathrm{O}$ were combined to measure endogenous glucose production and fractional gluconeogenesis. Glucose produced by gluconeogenesis after ingestion of ${ }^{2} \mathrm{H}_{2} \mathrm{O}$ was labeled with deuterium at the $\mathrm{C} 5$ position. Glucose molecules produced by gluconeogenesis and glycogenolysis were labeled with deuterium at the $\mathrm{C} 2$ position. The ratio of $\mathrm{C} 5$ and $\mathrm{C} 2$ enrichment of glucose represents the fractional gluconeogenesis. The $\mathrm{C} 2$ enrichment equals the plasma ${ }^{2} \mathrm{H}_{2} \mathrm{O}$ enrichment when in steady state, as was shown by Landau et al. (23). Therefore, plasma ${ }^{2} \mathrm{H}_{2} \mathrm{O}$ enrichment was measured instead of the $\mathrm{C} 2$ enrichment of glucose.

To measure fractional gluconeogenesis, the subjects ingested ${ }^{2} \mathrm{H}_{2} \mathrm{O}(99 \%$ enriched, Campro Scientific, Berlin, Germany) every half hour between $19.00 \mathrm{~h}$ and $21.00 \mathrm{~h}$ on day 2, up to a total dose of $5 \mathrm{~g} / \mathrm{kg}$ body water, to achieve a plasma ${ }^{2} \mathrm{H}_{2} \mathrm{O}$ enrichment of $\sim 0.5 \%$. Body water was estimated to be $73 \%$ of body fat free mass. Water consumed during the remainder of the study was enriched with $0.5 \%{ }^{2} \mathrm{H}_{2} \mathrm{O}$ to maintain isotopic steady state.

On day 3, a Venflon catheter (Becton Dickinson, Franklin Lanes, NJ) was placed in a superficial dorsal vein of the hand for blood sampling and another Venflon catheter was placed in a superficial vein of the other arm for intravenous infusion. The hand was placed in a thermostatically controlled hot box at $60^{\circ} \mathrm{C}$ to obtain arterialized venous blood samples. A blood sample was taken at $07.45 \mathrm{~h}$ to measure natural abundance of $\left[6,6-{ }^{2} \mathrm{H}_{2}\right]$ glucose and glucose and insulin concentrations. Immediately afterwards, a primed continuous infusion of [6,6${ }^{2} \mathrm{H}_{2}$ ]glucose (99\% enriched, Cambridge Isotopes, Andover, MA) was started at a rate of 0.11 $\mu \mathrm{mol} / \mathrm{kg} / \mathrm{min}$ (prime $11 \mu \mathrm{mol} / \mathrm{kg}$ ). At 130, 140 and 150 minutes after the start of the infusion, blood samples were taken to measure enrichment of $\left[6,6-{ }^{2} \mathrm{H}_{2}\right]$ glucose, plasma ${ }^{2} \mathrm{H}_{2} \mathrm{O}$ enrichment and deuterium enrichment at the $\mathrm{C} 5$ position of glucose.

\section{Gas chromatography and mass spectrometry}

Plasma ${ }^{2} \mathrm{H}_{2} \mathrm{O}$ enrichment was measured using isotope ratio mass spectroscopy (Optima, Micromass, Manchester, United Kingdom). Enrichments of plasma $\left[6,6-{ }^{2} \mathrm{H}_{2}\right]$ glucose and deuterium at the $\mathrm{C} 5$ position of glucose were determined as described previously (24). Briefly, the enrichment of plasma $\left[6,6-{ }^{2} \mathrm{H}_{2}\right]$ glucose was measured as the aldonitril pentaacetate derivative of glucose in deproteinized plasma. Glucose was monitored at mass-to-charge ratios $(\mathrm{m} / \mathrm{z})$ of 187 and 189 . The enrichment of $\left[6,6-{ }^{2} \mathrm{H}_{2}\right]$ glucose was determined by dividing the peak area of $m / z 189$ by the peak area of $m / z 187$, i.e. calculating the $M+2$ tracer-to-tracee ratio and correcting it for natural abundance. To measure deuterium enrichment at the $\mathrm{C5}$ position of glucose, glucose was converted to hexamethylenetetramine (HMT) as previously described by Landau et al. (23). HMT was injected into a gas chromatograph-mass spectrometer and was separated on an AT-Amine column ( $30 \mathrm{~m} \times 0.25 \mathrm{~mm}$, film thickness $\left(\mathrm{d}_{\mathrm{f}}\right) 0.25 \mu \mathrm{m}$ ). Isotopic enrichments were measured on a gas chromatograph-mass spectrometer (model 6890 gas chromatograph coupled to a model 5973 mass selective detector, equipped with electron impact ionization mode; Hewlett Packard, Palo Alto, CA).

\section{Glucose and insulin concentrations}

Blood was distributed into EDTA tubes for measurement of glucose and insulin concentrations. Blood samples were centrifuged at $4^{\circ} \mathrm{C}$ for 10 minutes at $3000 \mathrm{rpm}$. All samples were stored at $80^{\circ} \mathrm{C}$ until further analysis. Plasma glucose concentrations were determined using the 
hexokinase method (Glucose HK 125 kit, ABX diagnostics, Montpellier, France). Insulin concentrations were measured using RIA (Linco Research Inc., St. Charles, MO).

\section{Calculation and statistical analysis}

Endogenous glucose production was calculated by dividing the infusion rate of $\left[6,6-{ }^{2} \mathrm{H}_{2}\right]$ glucose by the resulting $M+2$ tracer-to-tracee ratio of plasma aldonitril pentaacetate glucose. This was done after correction for natural abundance by subtracting the natural abundance from the measured $M+2$ enrichment and after ascertaining that the $M+2$ tracer/tracee ratios were in steady state. The fractional gluconeogenesis was calculated by dividing deuterium enrichment at the $\mathrm{C} 5$ position of glucose by plasma ${ }^{2} \mathrm{H}_{2} \mathrm{O}$ enrichment. The absolute rate of gluconeogenesis was calculated by multiplying fractional gluconeogenesis by glucose production (24). A mean value of the 3 values obtained at 130, 140, and 150 minutes after the start of infusion was calculated.

Data are presented as mean \pm standard error to the mean (SEM), unless otherwise indicated. A paired T-test was carried out to test for differences in endogenous glucose production, fractional gluconeogenesis, absolute gluconeogenesis, concentrations of glucose and insulin, energy expenditure, and macronutrient balances between the $\mathrm{H}$ and $\mathrm{N}$ condition. Furthermore, a paired T-test was carried out to test whether energy and macronutrient balances were significantly different from zero. In order to study the possible relationship between gluconeogenesis and energy expenditure, the difference in gluconeogenesis between the high protein, carbohydratefree diet and the normal diet ( $\triangle \mathrm{GNG}$ ) and the difference in energy expenditure between the high protein, carbohydrate-free diet and the normal diet ( $\Delta \mathrm{EE}$ ) were calculated. These values were corrected for a potential order of treatment-effect by subtracting the mean value of $\Delta \mathrm{GNG}$ or $\Delta \mathrm{EE}$ of individuals with the same order of treatment of each individual value of $\Delta \mathrm{GNG}$ or $\Delta$ $\mathrm{EE}$, respectively. The values had a normal distribution. Pearson's correlation coefficient was used to test whether there was a linear correlation between $\Delta \mathrm{GNG}$ and $\Delta \mathrm{EE}$. Subsequently, a linear regression analysis was performed to obtain more information about the exact relationship between $\triangle$ GNG and $\triangle \mathrm{EE}$. A $p$-value $<0.05$ was regarded as statistically significant. Statistical procedures were performed using SPSS 15.0 (SPSS, Chicago, IL).

\section{RESULTS}

\section{Endogenous glucose production and gluconeogenesis}

Endogenous glucose production, i.e. glucose derived from glycogenolysis as well as gluconeogenesis, was lower when subjects were in the $\mathrm{H}$ condition than when subjects were in the $\mathrm{N}$ condition $(181 \pm 9 \mathrm{~g} / 24 \mathrm{~h}$ vs. $226 \pm 9 \mathrm{~g} / 24 \mathrm{~h}, \mathrm{p}<0.001)$, whereas fractional gluconeogenesis was higher $(0.95 \pm 0.04$ vs. $0.64 \pm 0.03, p<0.001)$. As a result, absolute gluconeogenesis tended to be higher when subjects were in the $\mathrm{H}$ condition than when subjects were in the $\mathrm{N}$ condition $(171 \pm 10 \mathrm{~g} / 24 \mathrm{~h}$ vs. $145 \pm 10 \mathrm{~g} / 24 \mathrm{~h}, \mathrm{p}=0.06)$.

\section{Glucose and insulin concentrations}

Fasting blood glucose concentration was lower when subjects were in the $\mathrm{H}$ condition than when subjects were in the $\mathrm{N}$ condition $(4.43 \pm 0.13 \mathrm{mmol} / \mathrm{l}$ vs. $5.07 \pm 0.10 \mathrm{mmol} / \mathrm{l}, \mathrm{p}<0.001)$. 
There was no difference in fasting insulin concentration between the $\mathrm{H}$ and $\mathrm{N}$ condition $(11.02 \pm$ $3.01 \mathrm{mU} / \mathrm{l}$ vs. $13.88 \pm 2.12 \mathrm{mU} / \mathrm{l}, \mathrm{ns})$.

\section{Energy expenditure}

Energy intake was $10.27 \pm 0.28 \mathrm{MJ}$ in the $\mathrm{H}$ and the $\mathrm{N}$ condition, and in both conditions subjects were in energy balance. Energy expenditure and its components are shown in table 3. RMR was greater in the $\mathrm{H}$ condition compared with the $\mathrm{N}$ condition $(8.46 \pm 0.23 \mathrm{MJ}$ vs. $8.12 \pm 0.31 \mathrm{MJ}$, $\mathrm{p}<0.05)$.

Table 3 Energy expenditure (MJ) in 10 healthy male subjects during consumption of a normal protein (N) with 12/55/33 $\%$ of energy from protein/carbohydrate/fat or a high protein, carbohydrate-free diet $(\mathrm{H})$ with $30 / 0 / 70 \%$ of energy from protein/carbohydrate/fat for 36 hours after an exhaustive glycogen-lowering exercise test

\begin{tabular}{lrr}
\hline & $\mathrm{N}$ & $\mathrm{H}$ \\
& & \\
& & \\
Total energy expenditure (MJ/day) & $10.06 \pm 0.34$ & $10.09 \pm 0.31$ \\
Sleeping metabolic rate (MJ/day) & $7.38 \pm 0.23$ & $7.50 \pm 0.25$ \\
Resting metabolic rate (MJ/day) & $8.12 \pm 0.31$ & $8.46 \pm 0.23 *$ \\
Diet-induced thermogenesis (MJ/day) & $0.74 \pm 0.10$ & $0.96 \pm 0.12$ \\
Activity-induced thermogenesis (MJ/day) & $1.94 \pm 0.17$ & $1.63 \pm 0.15$ \\
& & $0.17 \pm 0.12$ \\
\hline
\end{tabular}

Values are expressed as mean \pm SEM

Energy balance $=24 \mathrm{~h}$ energy intake $-24 \mathrm{~h}$ energy expenditure $(\mathrm{TEE})$

Paired T-test for differences between $\mathrm{H}$ and $\mathrm{N}, * \mathrm{p}<0.05$

\section{Substrate utilization}

The $24 \mathrm{~h} \mathrm{RQ}$ was lower in the $\mathrm{H}$ condition than in the $\mathrm{N}$ condition $(0.76 \pm 0.01$ vs. $0.85 \pm 0.01$, $\mathrm{p}<0.001)$.

There was a significant difference in protein, carbohydrate and fat balances between the two conditions $(p<0.001$, table 4$)$. In the $\mathrm{H}$ condition, subjects were in a positive protein balance $(p<0.001)$ and a negative carbohydrate balance $(p<0.01)$ whereas in the $N$ condition subjects were in a negative protein balance $(p<0.01)$, a positive carbohydrate balance $(p<0.01)$, and a negative fat balance $(p<0.05)$.

\section{Energy costs of gluconeogenesis}

There was a linear correlation between $\triangle \mathrm{GNG}$ and $\triangle \mathrm{EE}$ : Pearson's correlation coefficient was $0.70(p<0.05)$. The equation of the relationship between $\Delta \mathrm{GNG}$ and $\Delta \mathrm{EE}$ was:

$\Delta$ energy expenditure $=0.007 * \Delta$ gluconeogenesis -0.038

where $\Delta$ energy expenditure is the difference in energy expenditure between the $\mathrm{H}$ condition and the $\mathrm{N}$ condition in $\mathrm{MJ}$ and $\Delta$ gluconeogenesis is the difference in absolute gluconeogenesis between the $\mathrm{H}$ condition and the $\mathrm{N}$ condition in $\mathrm{g}\left(\mathrm{r}=0.70, \mathrm{R}^{2}=0.49, \mathrm{p}<0.05\right.$, figure 2$)$.

On average, in the $\mathrm{H}$ condition $26 \mathrm{~g}$ of extra glucose was produced through gluconeogenesis that resulted in an increase of energy expenditure of $0.144 \mathrm{MJ}$. The increase in energy expenditure after the high protein, carbohydrate-free diet compared with the normal protein diet was 0.340 
$\pm 0.132 \mathrm{MJ}$. Thus, the contribution of an increased gluconeogenesis to increased energy expenditure was $42 \%$. Since the energy content of $26 \mathrm{~g}$ glucose is $0.442 \mathrm{MJ}$, the energy costs to produce glucose through gluconeogenesis were $33 \%$ of the energy content of glucose $(95 \%$ confidence interval: $16 \%, 50 \%)$.

Table 4 Energy intake and energy expenditure, macronutrient intake and oxidation, and energy and macronutrient balances (all in MJ/day) in 10 healthy male subjects when on a normal protein diet $(\mathrm{N}$ ) with $12 / 55 / 33 \%$ of energy from protein/carbohydrate/fat or a high protein, carbohydrate-free diet $(\mathrm{H})$ with $30 / 0 / 70 \%$ of energy from protein/carbohydrate/fat for 36 hours after an exhaustive glycogen-lowering exercise test

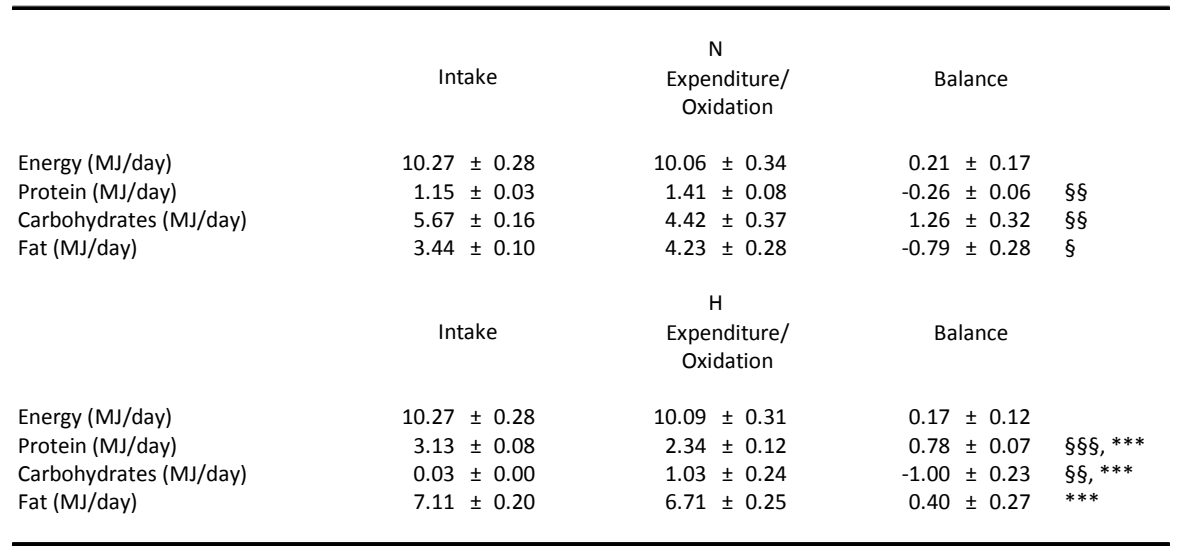

Values are expressed as mean \pm SEM

Paired T-test for energy- and macronutrient balances: differences from zero $(\S p<0.05, \S \S p<0.01, \S \S \S p<0.001)$ and between $\mathrm{H}$ and $\mathrm{N}(* * * \mathrm{p}<0.001)$

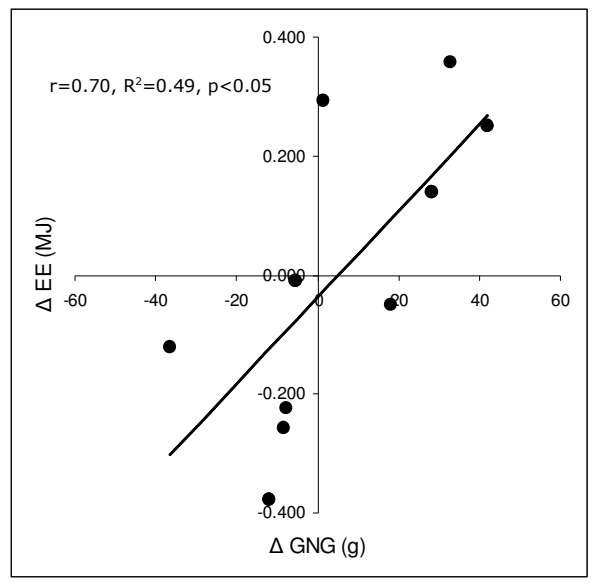

Figure 2 The relation between the difference in energy expenditure $(\Delta \mathrm{EE})$ and the difference in postabsorptive gluconeogenesis $(\Delta G N G)$ in healthy male subjects $(n=10)$ when subjects were on a high protein, carbohydrate-free diet (H) with $30 / 0 / 70 \%$ of energy from protein/ carbohydrate/fat or on a normal protein diet $(\mathrm{N})$ with $12 / 55 / 33 \%$ of energy from protein/carbohydrate/fat for 36 hours after an exhaustive glycogen lowering exercise test. $\Delta$ gluconeogenesis $=$ absolute gluconeogenesis in the $\mathrm{H}$ condition (g) - absolute gluconeogenesis in the $\mathrm{N}$ condition (g) and $\Delta$ energy expenditure = energy expenditure in the $\mathrm{H}$ condition (MJ) - energy expenditure in the $\mathrm{N}$ condition (MJ). $\Delta$ Values were corrected for a potential order of treatment-effect by subtracting the mean value of $\Delta$ GNG or $\triangle E E$ of individuals with the same order of treatment of each individual value of $\Delta \mathrm{GNG}$ or $\Delta \mathrm{EE}$, respectively.

Equation resulting from linear regression:

$\Delta$ energy expenditure $=0.007^{*} \Delta$ gluconeogenesis -0.038 $\left(r=0.70, R^{2}=0.49, p<0.05\right)$ 


\section{DISCUSSION}

Both gluconeogenesis and energy expenditure were increased when healthy subjects with low body glycogen stores were on a high protein, carbohydrate-free diet for one and a half day. The increase in energy expenditure was a function of the increase in gluconeogenesis. A major part, $42 \%$, of the increased energy expenditure at a high protein, carbohydrate-free diet was explained by increased gluconeogenesis. Plasma insulin concentration was not affected differently by the two diets, nor was there a relation between the change in insulin concentration and the change in gluconeogenesis after the two diets. Although insulin is known to be able to influence gluconeogenesis (14), in the present study insulin was not responsible for a change in glucose production or gluconeogenesis.

The infusion of $\left[6,6-{ }^{2} \mathrm{H}_{2}\right]$ glucose combined with ingestion of ${ }^{2} \mathrm{H}_{2} \mathrm{O}$ is a valid method for assessing postprandial endogenous glucose production and fractional gluconeogenesis $(23,25,26)$. An equilibration time for of 15 hours has been shown to be sufficient for ${ }^{2} \mathrm{H}_{2} \mathrm{O}$ to be equally distributed throughout the body water and to measure gluconeogenesis in a steady state (27). Although gluconeogenesis was previously shown to be relatively stable under varying metabolic conditions and was influenced minimally by a low carbohydrate diet for 11 days or a high protein diet for 6 months $(1,28,29)$, the present study shows that the relative contribution of gluconeogenesis to endogenous glucose production was increased dramatically under conditions of a high protein, carbohydrate-free diet and low body glycogen stores. Because body glycogen stores probably were not completely restored within this relatively short period by the high protein, carbohydrate-free diet (30), the rate of glycogenolysis decreased dramatically. Therefore, the relative contribution of gluconeogenesis increased to levels comparable with previous observed values after prolonged fasting $(23,31,32)$. Moreover, absolute gluconeogenesis also tended to be higher.

At the high protein, carbohydrate-free diet the contribution of increased gluconeogenesis to increased energy expenditure was $42 \%$. Although other energy-requiring pathways in protein metabolism, such as protein synthesis, may contribute to the increase in energy expenditure after a high protein diet $(6,33,34)$, the results of the present study showed that gluconeogenesis contributes for a major part $(42 \%)$ to the increased energy expenditure. The remaining variance may be explained by other energy-requiring pathways in protein metabolism, e.g. protein synthesis, protein oxidation, and ureagenesis. The energy costs of protein synthesis and protein breakdown have been estimated from theoretical values to be 3.6 $\mathrm{kJ} / \mathrm{g}$ and $0.7 \mathrm{~kJ} / \mathrm{g}$, respectively $(6,12,33,34)$. Nevertheless, they have not been actually measured and the contribution of these pathways to increased energy expenditure at a high protein diet requires further study. Previously, it has been shown from a theoretical perspective that an increased demand on protein and amino acid turnover for gluconeogenesis by a low carbohydrate diet increases energy expenditure (13). The energy costs to produce glucose through gluconeogenesis were $33 \%$ (95\% confidence interval: $16 \%, 50 \%)$ of the energy content of glucose. Hall previously estimated, based on published data, the energetic efficiency of gluconeogenesis to be 0.8 , which suggests that the energy costs of gluconeogenesis are $20 \%$ (12). This value of $20 \%$ is lower than the value of $33 \%$ we observed but within the $95 \%$ confidence interval. Taken together, the observed increase in gluconeogenesis contributed $42 \%$ 
to the increase in energy expenditure after the high protein, carbohydrate-free diet and the energy costs of gluconeogenesis are $33 \%$.

The contribution of the oxidation of the separate macronutrients to total energy expenditure was $23 / 10 / 67$ and $14 / 44 / 42 \%$ of energy from protein/carbohydrate/fat whereas the macronutrient intake was $30 / 0 / 70$ and $12 / 55 / 33 \%$ of energy from protein/carbohydrate/fat in the high protein, carbohydrate-free condition and the normal condition, respectively. In the normal condition there was a positive carbohydrate balance, and, considering that subjects performed exhaustive glycogen-lowering exercise, it is likely that the surplus of carbohydrates was stored as glycogen $(35,36)$. Macronutrient oxidation was relatively well adjusted to intake, also after the extremely high fat intake in the high protein, carbohydrate-free diet. Although fat stores are less controlled and adaptation of fat oxidation to fat intake normally is not abrupt, the body is able to rapidly increase fat oxidation to the level of fat intake in a glycogen-depleted state $(17,36,37)$. The glycogen-lowering exercise may also have affected the protein balance in the normal protein condition. A protein intake of $12 \mathrm{En} \%$ was not enough to obtain protein balance, whereas in a previous study with a comparable diet subjects were in protein balance on a diet with $10 \mathrm{En} \%$ from protein (5). Glycogen depletion has been shown to increase rates of muscle proteolysis and branched chain amino acid oxidation and probably is the reason for the relatively increased protein oxidation, hence a negative protein balance, in the normal diet (38). Thus, in both conditions macronutrient oxidation was relatively well adjusted to macronutrient intake, except that there was a positive carbohydrate balance in the normal condition. On the days before the experiments subjects consumed their habitual diets, which were adequate in protein (39). Glycogen-lowering exercise has been shown to increase the adaptation rate of substrate oxidation to macronutrient intake, requiring no longer adaptation period to the diets (17).

In healthy volunteers the process of hepatic autoregulation normally regulates endogenous glucose production tightly; a change in rate of gluconeogenesis is compensated for by a reciprocal change in rate of glycogenolysis so that total endogenous glucose production essentially does not change $(31,40,41)$. However, the high protein, carbohydrate-free diet reduced endogenous glucose production dramatically, which resulted in a lower blood glucose concentration. Apparently, the upregulation of gluconeogenesis was not sufficient to keep glucose concentration at the same level. Over time, hepatic autoregulation may be restored again. Hultman and Bergstrom showed that, although extremely slowly, a high protein diet with very low carbohydrate content restored glycogen stores (30). In the present study carbohydrate balance was $-55 \mathrm{~g}$, whereas endogenous glucose production was $181 \mathrm{~g}$. Hence, $\sim 125 \mathrm{~g}$ of the glucose endogenously produced was not immediately used for oxidation. This probably was stored as glycogen to restore body reserves. It may be that, after some time, the contribution of glycogenolysis to endogenous glucose production increases again. Further research is needed to see whether hepatic autoregulation will be restored.

The strength of this study was that it was the first to measure simultaneously the effects of a high protein, carbohydrate-free diet on endogenous glucose production and gluconeogenesis as well as on energy expenditure. The observed relation between the difference in gluconeogenesis and the difference in energy expenditure between the 2 diets allowed conclusions about the contribution of gluconeogenesis to energy expenditure. Moreover, for the first time the actual energy costs of gluconeogenesis were calculated. One of the limitations of the study was that 
the methods used did not allow for gluconeogenesis to be measured in the fed state because of the presence of futile cycles and the isotopic dilution of the precursor by unlabeled pools of metabolites (42). However, in the fed state the gluconeogenic rate was shown to be only modestly changed depending on the composition of the diet. Hence, the potency of observing differences may be reduced (1). Another limitation is that the 2 diets differed not only in protein content, but also in carbohydrate and fat contents. This is inevitable, because when the contribution of one macronutrient is changed, the contributions of the other macronutrients always change to maintain the same total energy intake. Because the main question to be answered was whether gluconeogenesis can be increased, the carbohydrate content of the diet, hence carbohydrate availability, should be low to be able to sensitively study the acute effects of high protein intake on gluconeogenesis (1). A protein intake of $30 \%$ of energy from protein was chosen as being representative for high protein diets studied in energy balance $(43,44)$. The remaining part of energy intake in the high protein, carbohydrate-free condition had to be from fat. Because fat is a thermoneutral ingredient, i.e. it does not increase diet-induced energy expenditure, it is not likely that the higher fat intake affected energy expenditure (45). Previously, a high fat, low carbohydrate diet resulted in decreased basal endogenous glucose production. Unfortunately gluconeogenesis was not measured in this study (46). Because a high fat intake does not increase energy expenditure, it is not expected that an increased fat intake increases energy expenditure via an increased gluconeogenesis.

In conclusion, an increased gluconeogenesis contributes to an increased energy expenditure after a high protein, carbohydrate-free diet that was consumed for one and a half day when body glycogen stores had been lowered beforehand. $42 \%$ of the increase in energy expenditure after a high protein, carbohydrate-free diet was explained by the increase in gluconeogenesis. The energy costs of gluconeogenesis are $33 \%$ of the energy content of glucose.

\section{ACKNOWLEDGEMENTS}

We gratefully acknowledge Mariette Ackermans and An Ruiter from the Laboratory of Endocrinology and Radiochemistry of the Academic Medical Center, University of Amsterdam for their advise with respect to the stable isotope techniques and their technical assistance with the analyses of $\left[6,6-{ }^{2} \mathrm{H}_{2}\right]$ glucose and deuterium enrichment at the $\mathrm{C} 5$ position of glucose.

MABV, MSW-P, and KRW designed the study. MABV collected and analyzed the data and wrote the manuscript. MSW-P and KRW contributed to interpretation of the data and reviewed the manuscript. None of the authors had a personal or financial conflict of interest.

\section{REFERENCES}

1. Nuttall FQ, Ngo A, Gannon MC. Regulation of hepatic glucose production and the role of gluconeogenesis in humans: is the rate of gluconeogenesis constant? Diabetes Metab Res Rev 2008;24:438-58.

2. Azzout B, Chanez M, Bois-Joyeux B, Peret J. Gluconeogenesis from dihydroxyacetone in rat hepatocytes during the shift from a low protein, high carbohydrate to a high protein, carbohydrate-free diet. J Nutr 1984;114:216778.

3. Kaloyianni M, Freedland RA. Contribution of several amino acids and lactate to gluconeogenesis in hepatocytes isolated from rats fed various diets. J Nutr 1990;120:116-22. 
4. Azzout-Marniche D, Gaudichon C, Blouet C, et al. Liver glyconeogenesis: a pathway to cope with postprandial amino acid excess in high-protein fed rats? Am J Physiol Regul Integr Comp Physiol 2007;292:R1400-7.

5. Lejeune MP, Westerterp KR, Adam TC, Luscombe-Marsh ND, Westerterp-Plantenga MS. Ghrelin and glucagonlike peptide 1 concentrations, 24-h satiety, and energy and substrate metabolism during a high-protein diet and measured in a respiration chamber. Am J Clin Nutr 2006;83:89-94.

6. Mikkelsen PB, Toubro S, Astrup A. Effect of fat-reduced diets on 24-h energy expenditure: comparisons between animal protein, vegetable protein, and carbohydrate. Am J Clin Nutr 2000;72:1135-41.

7. Westerterp-Plantenga MS, Rolland V, Wilson SA, Westerterp KR. Satiety related to $24 \mathrm{~h}$ diet-induced thermogenesis during high protein/carbohydrate vs high fat diets measured in a respiration chamber. Eur J Clin Nutr 1999;53:495-502.

8. Crovetti R, Porrini M, Santangelo A, Testolin G. The influence of thermic effect of food on satiety. Eur J Clin Nutr 1998;52:482-8.

9. Halton TL, Hu FB. The effects of high protein diets on thermogenesis, satiety and weight loss: a critical review. J Am Coll Nutr 2004;23:373-85.

10. Johnston CS, Day CS, Swan PD. Postprandial thermogenesis is increased $100 \%$ on a high-protein, low-fat diet versus a high-carbohydrate, low-fat diet in healthy, young women. J Am Coll Nutr 2002;21:55-61.

11. Westerterp KR, Wilson SA, Rolland V. Diet induced thermogenesis measured over $24 \mathrm{~h}$ in a respiration chamber: effect of diet composition. Int J Obes Relat Metab Disord 1999;23:287-92.

12. Hall KD. Computational model of in vivo human energy metabolism during semistarvation and refeeding. Am J Physiol Endocrinol Metab 2006;291:E23-37.

13. Feinman RD, Fine EJ. Thermodynamics and metabolic advantage of weight loss diets. Metab Syndr Relat Disord 2003;1:209-19.

14. Exton JH. Gluconeogenesis. Metabolism 1972;21:945-90.

15. Kuipers H, Keizer HA, Brouns F, Saris WH. Carbohydrate feeding and glycogen synthesis during exercise in man. Pflugers Arch 1987; $410: 652-6$.

16. Harris JA, Benedict FG. A biometric study of basal metabolism in man. Proc Natl Acad Sci 1918;4:370-373.

17. Schrauwen P, van Marken Lichtenbelt WD, Saris WH, Westerterp KR. Role of glycogen-lowering exercise in the change of fat oxidation in response to a high-fat diet. Am J Physiol 1997;273:E623-9.

18. Schoffelen PF, Westerterp KR, Saris WH, Ten Hoor F. A dual-respiration chamber system with automated calibration. J Appl Physiol 1997;83:2064-72.

19. Brouwer E. On simple formulae for calculating the heat expenditure and the quantities of carbohydrate and fat oxidized in metabolism of men and animals, from gaseous exchange (Oxygen intake and carbonic acid output) and urine-N. Acta Physiol Pharmacol Neerl 1957;6:795-802.

20. van Marken Lichtenbelt WD, Westerterp KR, Wouters L. Deuterium dilution as a method for determining total body water: effect of test protocol and sampling time. Br J Nutr 1994;72:491-7.

21. Schoeller DA, van Santen E, Peterson DW, Dietz W, Jaspan J, Klein PD. Total body water measurement in humans with 180 and $2 \mathrm{H}$ labeled water. Am J Clin Nutr 1980;33:2686-93.

22. Siri WE. Body composition from fluid spaces and density: analysis of methods. 1961. Nutrition 1993;9:480-91; discussion 480, 492.

23. Landau BR, Wahren J, Chandramouli V, Schumann WC, Ekberg K, Kalhan SC. Contributions of gluconeogenesis to glucose production in the fasted state. J Clin Invest 1996;98:378-85.

24. Ackermans MT, Pereira Arias AM, Bisschop PH, Endert E, Sauerwein HP, Romijn JA. The quantification of gluconeogenesis in healthy men by (2) $\mathrm{H} 2 \mathrm{O}$ and [2-(13)C]glycerol yields different results: rates of gluconeogenesis in healthy men measured with $(2) \mathrm{H} 2 \mathrm{O}$ are higher than those measured with [2-(13)C]glycerol. J Clin Endocrinol Metab 2001;86:2220-6.

25. Landau BR. Quantifying the contribution of gluconeogenesis to glucose production in fasted human subjects using stable isotopes. Proc Nutr Soc 1999;58:963-72.

26. Landau BR, Wahren J, Chandramouli V, Schumann WC, Ekberg K, Kalhan SC. Use of $2 \mathrm{H} 2 \mathrm{O}$ for estimating rates of gluconeogenesis. Application to the fasted state. J Clin Invest 1995;95:172-8.

27. Allick G, van der Crabben SN, Ackermans MT, Endert E, Sauerwein HP. Measurement of gluconeogenesis by deuterated water: the effect of equilibration time and fasting period. Am J Physiol Endocrinol Metab 2006;290:E1212-7.

28. Bisschop PH, Pereira Arias AM, Ackermans MT, et al. The effects of carbohydrate variation in isocaloric diets on glycogenolysis and gluconeogenesis in healthy men. J Clin Endocrinol Metab 2000;85:1963-7.

29. Linn T, Santosa B, Gronemeyer D, et al. Effect of long-term dietary protein intake on glucose metabolism in humans. Diabetologia 2000;43:1257-65.

30. Hultman E, Bergstrom J. Muscle glycogen synthesis in relation to diet studied in normal subjects. Acta Med Scand 1967;182:109-17.

31. Staehr $\mathrm{P}$, Hother-Nielsen $\mathrm{O}$, Beck-Nielsen $\mathrm{H}$, et al. Hepatic autoregulation: response of glucose production and gluconeogenesis to increased glycogenolysis. Am J Physiol Endocrinol Metab 2007;292:E1265-9.

32. Katz J, Tayek JA. Gluconeogenesis and the Cori cycle in 12-, 20-, and 40-h-fasted humans. Am J Physiol 1998;275:E537-42. 
33. Robinson SM, Jaccard C, Persaud C, Jackson AA, Jequier E, Schutz Y. Protein turnover and thermogenesis in response to high-protein and high-carbohydrate feeding in men. Am J Clin Nutr 1990;52:72-80.

34. van Milgen J. Modeling biochemical aspects of energy metabolism in mammals. J Nutr 2002;132:3195-202.

35. Acheson KJ, Schutz Y, Bessard T, Ravussin E, Jequier E, Flatt JP. Nutritional influences on lipogenesis and thermogenesis after a carbohydrate meal. Am J Physiol 1984;246:E62-70.

36. Abbott WG, Howard BV, Christin L, et al. Short-term energy balance: relationship with protein, carbohydrate, and fat balances. Am J Physiol 1988;255:E332-7.

37. Schrauwen $P$, van Marken Lichtenbelt WD, Saris WH, Westerterp KR. Changes in fat oxidation in response to a high-fat diet. Am J Clin Nutr 1997;66:276-82.

38. De Feo P, Di Loreto C, Lucidi P, et al. Metabolic response to exercise. J Endocrinol Invest 2003;26:851-4.

39. Hulshof K, Ocke M, van Rossum C, et al. Results of the Food Consumption Survey 2003 (In Dutch: Resultaten van de Voedselconsumptiepeiling 2003). Bilthoven/Zeist: RIVM/TNO, 2004.

40. Jenssen T, Nurjhan N, Consoli A, Gerich JE. Failure of substrate-induced gluconeogenesis to increase overall glucose appearance in normal humans. Demonstration of hepatic autoregulation without a change in plasma glucose concentration. J Clin Invest 1990;86:489-97.

41. Boden G. Effects of free fatty acids on gluconeogenesis and glycogenolysis. Life Sci 2003;72:977-88.

42. Hue L. Gluconeogenesis and its regulation. Diabetes Metab Rev 1987;3:111-26.

43. Protein and amino acid requirements in human nutrition. World Health Organ Tech Rep Ser 2007:1-265, back cover.

44. Westerterp-Plantenga MS. Protein intake and energy balance. Regul Pept 2008;149:67-9.

45. Westerterp KR. Diet induced thermogenesis. Nutr Metab (Lond) 2004;1:5.

46. Bisschop PH, de Metz J, Ackermans MT, et al. Dietary fat content alters insulin-mediated glucose metabolism in healthy men. Am J Clin Nutr 2001;73:554-9. 
Chapter 10

\section{General discussion}



The research presented in this thesis shows that the higher satiety that has been observed after high protein meals or diets with mixed types of protein holds for some, but not all, specific types of protein. A breakfast with a relatively high concentration of casein or soy is more satiating than a breakfast with a normal concentration of casein or soy, respectively (1-3). Contrarily, a breakfast with a normal concentration of whey is more satiating than a breakfast with a relatively high concentration of whey (4). In addition, a hierarchy in satiating efficacies between different types of protein appears to exist. Whey is more satiating than casein or soy (5). Moreover, a breakfast with whey reduces subsequent energy intake compared with a breakfast with whey without glycomacropeptide (GMP) (4). Alpha-lactalbumin, gelatin, or gelatin with added tryptophan (TRP) reduce subsequent hunger and energy intake compared with casein, soy, whey, or whey without GMP. It is not necessarily a relatively high protein intake that induces satiety: alpha-lactalbumin, gelatin, or gelatin with added TRP reduce subsequent energy intake already when consumed in a meal with a normal protein content (6). In general, differences in satiety coincide, synchronize, or relate to elevated concentrations of (specific) amino acids. On the other hand, differences in satiety between types of protein appear not to be directly related to differences in concentrations of (an)orexigenic hormones such as GLP-1, insulin, or ghrelin (1-6). The appetite suppressive effect of a high protein diet is even enhanced by the absence of a normal proportion of carbohydrates in the diet. Due to the relatively high proportion of dietary fat, postprandial dietary fat oxidation and elevated concentrations of ketone bodies are involved in this effect and contribute to protein-induced hunger suppression (7). High protein intake affects the other side of the energy balance, i.e. energy expenditure, as well. A high protein diet increases energy expenditure irrespective of the presence or absence of a normal proportion of carbohydrates, indicating that it actually is the high protein content of a diet that increases energy expenditure $(7,8)$. Here, it is gluconeogenesis that is of importance: the increase in energy expenditure is for nearly $50 \%$ explained by increased gluconeogenesis. The energy costs of gluconeogenesis are one third of the energy content of glucose (8).

The general discussion of this thesis first addresses effects of different types and concentrations of dietary proteins on appetite and subsequent energy intake. Secondly, protein-induced energy expenditure and the contribution of gluconeogenesis to increased energy expenditure are evaluated. Subsequently, effects of dietary proteins on energy intake and energy expenditure i.e. energy balance are integrated. Implications for weight loss diets and weight maintenance after weight loss are discussed. Finally, the conclusions are presented followed by suggestions for future research.

\section{PROTEIN-INDUCED SATIETY}

With respect to protein-induced satiety, the aim of the research presented in this thesis was to address the questions 1 ) whether a higher satiety after high protein intake holds for specific types of protein, 2) whether different types of protein have different satiating efficacies, and 3) whether differences in protein-induced satiety may be attributed to differences in (an)orexigenic hormones and/or amino acid responses. In addition, it was studied whether the presence or absence of a normal proportion of carbohydrates in a high protein diet affects appetite. 
Some, but not all types of protein are more satiating in a relatively high concentration compared with a normal concentration. Moreover, differences in satiating efficacies between types of protein occur. The differences in satiating efficacies between different concentrations or types of protein are to a certain extent attributable to the same mechanisms, i.e. increased postprandial amino acid concentrations and the presence or absence of specific amino acids. However, there is no general mechanism for protein-induced satiety, there are several pathways for proteins to affect appetite. Regression analyses were performed in order to study effects of specific amino acids on appetite suppression, resulting in a significant relationship between taurine and appetite suppression after consumption of a breakfast with soy. Other than that, no relationships between amino acids and appetite-suppression were observed. Subsequently, principal component analyses were carried out per type and concentration of protein in order to study whether there may be a group of amino acids that can be correlated to appetite suppression $(4,5,9)$. The results of those analyses are presented in table 1 . The principal components of the total amino acid response after a specific breakfast are shown per row. The total explained variance and the proportion explained variation of each component to the total amino acid response are indicated per breakfast. There was no single amino acid nor a group of amino acids that consistently contributed to total amino acid response. Moreover, there was no single amino acid nor a group of amino acids that resulted from the analyses after the more satiating types of protein (alpha-lactalbumin, gelatin, or gelatin+TRP) and not from the less satiating types of protein (casein, soy, whey, or whey-GMP). This suggests that there is no group of amino acids that is generally directly related to appetite suppression. A possible relation between amino acids and appetite suppression thus is dependent on the type of dietary protein. Nevertheless, amino acid concentrations have an important role in protein-induced satiety. 


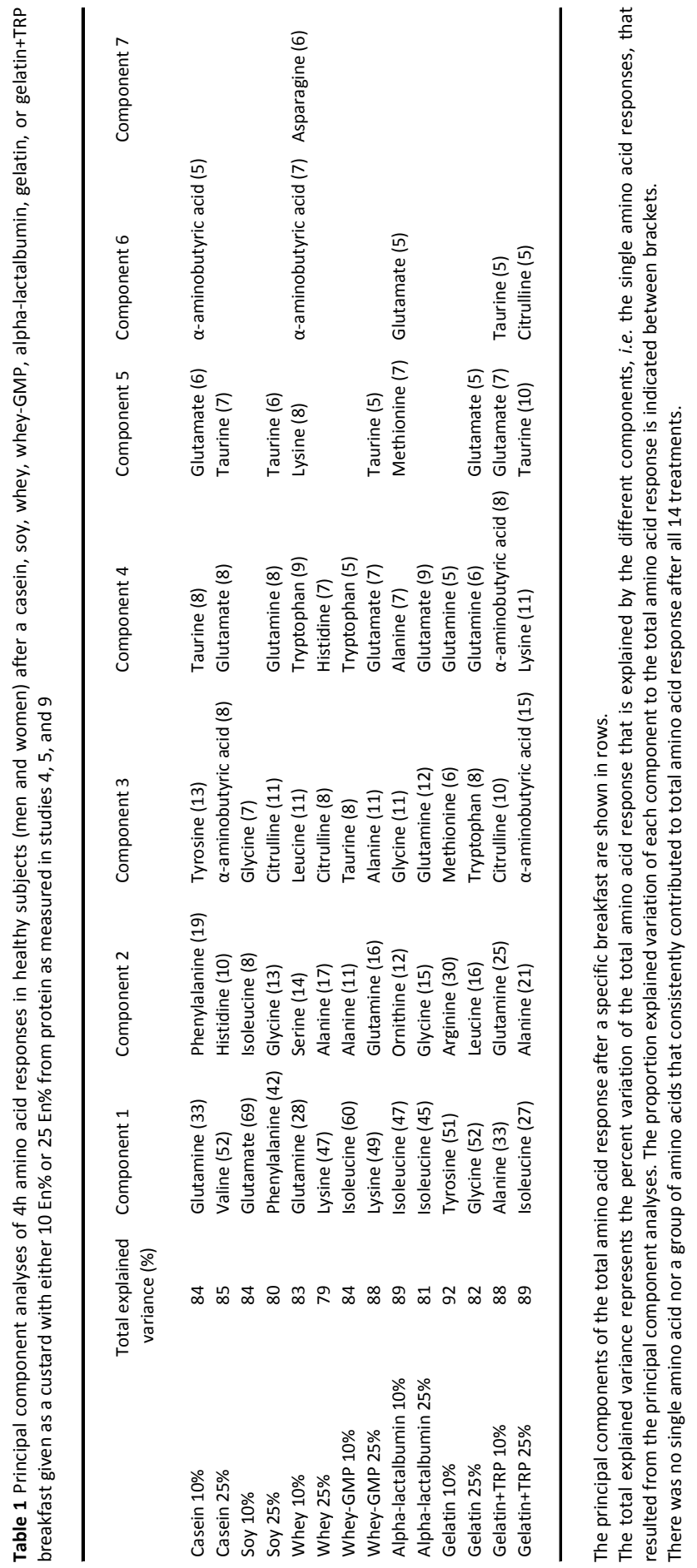




\section{Postprandial amino acid concentrations}

Increased postprandial concentrations of amino acids are one of the triggers for protein-induced satiety. Increased ratings of satiety and fullness synchronized with elevated concentrations of amino acids after a breakfast with a relatively high amount of casein compared with a normal amount of casein (1). An elevated concentration of plasma amino acids serves as a satiety signal for a food intake regulating mechanism, as was proposed already in 1956 in the amino static theory of Mellinkoff (10). Variations in free amino acid concentrations can be directly recorded by the central nervous system: the orexigenic and anorexigenic circuits in the arcuate nucleus are sensitive to circulating amino acid concentrations (11). Independent of the nervus vagus, increased amino acid concentrations enhance the anorexigenic melanocortin neuron activity in the arcuate nucleus resulting in a suppressed appetite (12). The ability of amino acids to suppress food intake and regulate neuropeptide expression likely depends on AMP-activated protein kinase (AMPK) and the mammalian target of rapamycin (mTOR) (11). AMPK and mTOR are the cellular mediators of a hypothalamic protein-sensing system $(13,14)$. AMPK is the downstream component of a kinase cascade and is activated by rising AMP coupled with falling ATP concentrations (14). mTOR is an intracellular signaling molecule that is sensitive to amino acids as well as growth factors. The activation of mTOR and the suppression of AMPK phosphorylation activity modulate hypothalamic neuropeptides, including a decrease in the orexigenic neurotransmitters neuropeptide $\mathrm{Y}$ (NPY) and agouti-related peptide (AgRP) and an increase in the anorexigenic pro-opiomelanocortin (POMC) (13-15). Thus, increased postprandial amino acid concentrations are recorded by the brain, resulting in decreased NPY and AgRP and increased POMC. Feelings of satiety and fullness are increased whereas experienced hunger and desire to eat are not affected (1). This implies that increased postprandial amino acid concentrations induce a satiety effect rather than a satiation effect, i.e. they increase the wish to postpone a next eating episode. Elevated postprandial amino acid concentrations contribute to differences in satiating efficacies between different amounts of the same type of protein as well as between different types of protein at the same concentration $(1,5)$.

When different proteins are consumed at very high levels, the postprandial amino acid concentrations are elevated above a certain level with all types of protein. As a result, satiety is very high and differences in satiating efficacies are no longer observed. For instance, there was no difference in satiating efficacy between casein, soy, or whey at a relatively high concentration, whereas at a normal protein concentration whey was more satiating than casein or soy (5). Accordingly, Bowen et al. reported no differences between effects of casein and whey or between whey, soy, and gluten in amounts of $>50 \%$ of energy, with high protein meals inducing a larger satiating effect than high carbohydrate meals $(16,17)$. Burton-Freeman et al. did not find a difference in food intake between preloads with $44 \%$ of energy from whey with or without GMP (18).

Differences in protein kinetics affect postprandial amino acid concentrations, hence satiating efficacies of proteins. The rate at which proteins are digested and absorbed are different: whey is a soluble protein whereas casein coagulates in the stomach which delays gastric emptying (19, 20). Therefore, whey and casein are considered as 'fast' and 'slow' proteins, respectively. The delayed gastric emptying results in slower release of amino acids whereas postprandial amino acid concentrations are more elevated after ingestion of rapidly digested proteins $(19,21-23)$. 
These increased postprandial amino acid concentrations give rise to an increased satiety, hence, proteins with a higher digestion rate are more satiating than proteins with a lower digestion rate $(5,19,21-23)$.

\section{Specific amino acids}

Apart from increased postprandial amino acid concentrations, specific amino acids contribute to protein-induced satiety. After a breakfast with a relatively high soy content increased concentrations of the amino acid taurine were related to increased satiety and increased hunger suppression (2). Taurine previously was shown to depress food intake in mice (24). Moreover, taurine supplementation has been shown to decrease body weight significantly in obese mice and in overweight and obese human subjects $(25,26)$. A relation with appetite in humans was observed earlier since for example for sea foods, rich in taurine, the satiating effect was explained by increased taurine concentrations $(27,28)$. Taurine plays a role in numerous physiological processes, including conjugation of bile acids, detoxification, and osmoregulation $(29,30)$. The hypothalamus may be involved in the effect of taurine on the control of food intake, since increased taurine concentrations in the hypothalamus have been observed after intraperitoneal injection (24). However, the exact mechanism via which taurine affects appetite is unknown and needs further study.

Other specific amino acids may also have specific roles in the control of food intake, because differences in satiating efficacies between types of protein coincided with differences in responses of specific amino acids $(4,5)$. For instance, leucine is suggested to affect food intake specifically via the AMPK and mTOR pathway. Intracerebroventricular administration of leucine, but not other amino acids, reduced food intake in a dose-dependent manner (15). Moreover, the magnitude of weight loss and reduction of food intake after a leucine-supplemented diet was similar to that achieved after a high protein diet (14). Leucine intake has been shown to be associated with decreased AMPK activity and increased activity of mTOR $(13,14)$. Other amino acids, e.g. serine, threonine, alanine, alpha-aminobutyric acid, valine, and isoleucine may also affect this or other pathways and thereby the control of food intake.

In the past, the amino acid tryptophan (TRP) has been suggested to be involved in appetite regulation because it serves as a precursor for serotonin (31-35). However, the presence or absence of TRP in protein did not affect satiety differently when compared with other types of protein. Breakfasts with alpha-lactalbumin, gelatin, or gelatin with added TRP reduced energy intake at lunch to the same extent compared with a breakfast with casein, soy, whey, or whey without GMP (6). Similar results were obtained in another experiment where addition of TRP to gelatin did not affect appetite ratings. Moreover, both plasma TRP concentrations and the plasma TRP:LNAA ratio were not related to hunger (9). Therefore, it is unlikely that TRP contributes to protein-induced satiety via an increased TRP:LNAA ratio and serotonin concentration.

\section{'Incomplete' proteins}

The quality of a type of protein appears to be involved in hunger suppression. Protein quality is mainly determined by the amino acid composition of the protein. Some proteins are considered as 'incomplete' or 'lower quality' proteins because they are lacking one or more essential amino acids or are having an inadequate essential amino acid balance (36). Gelatin is considered as an 
incomplete protein because it is lacking TRP and contains relatively low amounts of the other essential amino acids, i.e. histidine, isoleucine, leucine, lysine, methionine, phenylalanine, threonine, and valine (6). The addition of TRP does not improve the protein quality of gelatin to a large extent. Both gelatin and gelatin with added TRP suppress hunger more than other types of protein: subsequent energy intake was decreased after a breakfast with gelatin or gelatin with added TRP compared with casein, soy, whey, or whey without GMP (6). This is probably attributable to the low protein quality of gelatin and gelatin with added TRP. It has been shown that animals reject diets that lead to depletion or deficiency of essential amino acids (the 'indispensable amino acid deficiency' theory). After rejection of such a diet animals begin foraging for a better essential amino acid source and develop conditioned aversions to cues associated with the deficient diet (37). A chemosensor for essential amino acid deficiency has been found in the anterior periform cortex (38). From this area signals are projected to other brain areas that are associated with the control of food intake (37). Likewise, consumption of an incomplete protein may be detected and result in a signal to stop eating in humans. In our studies subjects could not stop eating at the moment they felt for it because they had to consume a fixed amount of breakfast. This resulted in an increased satiety and reduced energy intake at the next meal (6). Nevertheless, the signal of incomplete proteins seems to be a signal of hunger suppression rather than a satiation or satiety signal.

\section{Ketone bodies}

A ketogenic state contributes to appetite suppression: a high protein, high fat, carbohydratefree diet induced an increased dietary fat oxidation and increased concentration of ketone bodies and suppressed appetite more than a high protein, normal fat, normal carbohydrate diet (7). Increased dietary fat oxidation is suggested to reduce appetite whereas inhibition of fatty acid oxidation increases food intake (39-43). The reduction of appetite with increased dietary fat oxidation may be due to stimulation of carnitine palmitoyl transferase-1 (CPT-1), a catalyst of the rate-limiting step in mitochondrial fatty acid oxidation (39). Increased fat oxidation with low carbohydrate availability results in the production of ketone bodies (44). Ketone bodies are formed from amino acids, hence consumption of a diet that is high in ketogenic amino acids results in an increased production of ketone bodies. $\beta$-Hydroxybutyrate, which is the most important ketone body in the blood (44), reduced food intake after intracerebroventricular infusion or subcutaneous injection in rats $(45,46)$. Moreover, higher $\beta$-hydroxybutyrate concentrations coinciding with reduced appetite and increased weight loss have been reported in several studies $(41,47,48)$. Leucine and lysine are the only two amino acids that are solely ketogenic amino acids; isoleucine, phenylalanine, tryptophan, and tyrosine are both ketogenic and glucogenic (49). High protein diets with proteins that predominantly consist of ketogenic amino acids may result in increased ketone body concentrations which in turn may contribute to increased satiety. Whey and alpha-lactalbumin have a relatively high leucine and lysine content and this may have contributed to the increased satiety after whey compared with casein or soy and after alpha-lactalbumin compared with casein, soy, whey, and whey without $\operatorname{GMP}(5,6)$.

\section{(An)orexigenic hormones}

Changes in concentrations of gastrointestinal (an)orexigenic hormones have been hypothesized to contribute to differences in satiating efficacies of different types of protein $(17,23,50-52)$. 
Variations in concentrations of these hormones are directly recorded by the central nervous system and thereby may affect the control of food intake $(53,54)$. Our studies have shown that differences in satiety sometimes, but not always, are supported by differences in the response of (an)orexigenic hormones, e.g. insulin, GLP-1, or ghrelin $(2,6)$. It is clear that the supposed relationship between satiety and (an)orexigenic hormone concentrations is not mathematically present $(1,4,5)$. The release of (an)orexigenic hormones is a physiological, nutrient specific response that may contribute to satiety, but is not necessarily directly related to satiety. For instance, an increased insulin response after protein intake can be attributed to higher concentrations of insulinotrophic amino acids. Some amino acids, e.g. leucine, arginine, phenylalanine, and tyrosine specifically stimulate the release of insulin $(55,56)$. When these amino acids are present in a larger amount in a meal, because of increased total protein content or specific type of protein, postprandial insulin concentrations are increased $(2,5,57,58)$. This nutrient specific response does not automatically imply a satiety response, other factors, such as amino acid concentrations, appear to determine the level of satiety to a larger extent $(1,4,5)$. Another example is the release of GLP-1 after consumption of whey. Whey inhibits dipeptidyl peptidase IV activity, the enzyme involved in the breakdown of GLP-1, thus prolonging the action of GLP-1 (59). A larger amount of whey inhibits the breakdown of GLP-1 thereby inducing an elevated GLP-1 response without an increased satiety response (4). Moreover, the (an)orexigenic hormones stimulate or inhibit the secretion of other hormones. GLP-1 stimulates insulin secretion whereas insulin has been reported to inhibit GLP-1 secretion, probably as a negative feedback loop (60-62). Additionally, there are some suggestions that the suppression of ghrelin concentrations is dependent on postprandial insulin concentrations (63). Thus, the release of (an)orexigenic hormones is a physiological response to the presence of amino acids or other hormones which may contribute to, rather than mathematically relate to satiety. This implies that concentrations of (an)orexigenic hormones are not a representative biomarker for satiety, but may be used as qualitative indications. Conclusions with respect to satiating efficacies of types of protein should not be based on concentrations of (an)orexigenic hormones but on appetite ratings and energy intake.

Taken together, differences in satiating efficacies between concentrations or types of protein occur. Satiating efficacies of types of protein can only be compared when pure proteins are used: there were no differences with respect to satiety or food intake between egg albumin, casein, gelatin, soy, pea, or wheat gluten when only $60-70 \%$ of total protein consisted of the specific protein type under investigation $(64,65)$. Differences in satiating efficacies can be attributed to differences in amino acid composition and postprandial amino acid responses. Apart from the effect on energy intake, there is also an effect of protein intake on energy expenditure. This indirectly affects protein-induced satiety yet primarily is a separate beneficial effect with respect to body weight loss and weight maintenance (54).

\section{PROTEIN-INDUCED ENERGY EXPENDITURE}

Energy expenditure is increased after consumption of relatively high protein meals or diets, i.e. effects are short term as well as longer term. A high protein diet increases energy expenditure 
irrespective of the presence or absence of a normal proportion of carbohydrates (7). Also with a single type of protein as protein source, energy expenditure is higher after a high protein diet compared with a normal protein diet (66). Two of the three major components of $24 \mathrm{~h}$ energy expenditure are affected by high protein intake. Firstly, a high protein diet increases dietinduced thermogenesis (DIT) $(51,67-71)$. In general, DIT refers to the stimulation of energyrequiring processes during the postprandial period: intestinal absorption of nutrients, initial steps of their metabolism, and storage of the absorbed but not immediately oxidized nutrients (72). In the case of proteins, an increase in DIT can be attributed to an increased ATP requirement for the initial steps of protein metabolism. The body has no storage capacity to cope with high protein intake and proteins are metabolized immediately. The processes involved, including protein oxidation and ureagenesis, induce an increase in DIT $(73,74)$. However, gluconeogenesis appears not to contribute to an increased DIT at a high protein diet (8). As there are differences in amino acid catabolism and urea synthesis between different amino acids, the energy costs of protein breakdown and ureagenesis may vary between different types of protein, and have been estimated to amount on average $0.7 \mathrm{~kJ}$ per gram protein $(75,76)$. However, the exact energy costs and contribution of protein breakdown and ureagenesis to an increased DIT have not been measured yet.

The other major component of energy expenditure that is increased after high protein intake is resting energy expenditure: when high protein intake is sustained for one or more days it results in an increase in resting energy expenditure $(8,51,73,74)$. An increase in gluconeogenesis contributes substantially to this effect: nearly $50 \%$ of the increase in energy expenditure after a high protein diet was explained by an increase in gluconeogenesis. The energy costs of gluconeogenesis are relatively high, they amount one third of the energy content of glucose (8). Thus, gluconeogenesis is an energetically costly pathway for the body to cope with high protein intake. In addition to gluconeogenesis, protein synthesis and protein turnover contribute to an increase in resting energy expenditure $(73,74)$. The energy costs of protein synthesis have been estimated to amount $3.6 \mathrm{~kJ}$ per gram protein (75). The amount of protein synthesis after protein intake, hence its stimulatory effect on energy expenditure, depends on how well the composition of essential amino acids in the dietary protein matches the requirements for protein synthesis in the body. A well-balanced amino acid mixture, i.e. a 'complete' protein, produces a higher thermogenic response than does an amino acid mixture with a lower biological value, i.e. a different amino acid composition than is used for protein synthesis (77). Both pork and soy protein produced a significantly higher thermic effect than a carbohydrate diet. Consumption of animal protein increased energy expenditure with $2 \%$ compared with soy protein (73). The exact energy costs of protein synthesis or protein breakdown have not been measured and require further research.

Since gluconeogenesis contributes for a major part to the increased energy expenditure after a high protein diet (8), additional stimulation of gluconeogenesis could be a tool to further increase energy expenditure. This may be accomplished by using proteins that are rich in glucogenic amino acids, i.e. glycine, serine, valine, histidine, arginine, cysteine, proline, alanine, glutamine, glutamate, asparagine, and methionine. Glucogenic amino acids are degraded to pyruvate or one of the intermediates of the tricarboxylic acid cycle and are converted to glucose via gluconeogenesis (49). A high protein diet rich in glucogenic amino acids could stimulate gluconeogenesis more and thereby increase energy expenditure to a larger extent. 
Taken together, a high protein diet increases energy expenditure via an increase in diet-induced thermogenesis and/or resting energy expenditure. An increase in gluconeogenesis contributes for a major part (nearly 50\%) to the increased resting energy expenditure. Differences in amino acid composition of different types of protein may stimulate gluconeogenesis and thereby energy expenditure differently. The effect of high protein intake on energy expenditure indirectly affects protein-induced satiety. Nevertheless, it primarily is a separate beneficial effect with respect to body weight loss and weight maintenance. During a weight loss diet, high protein intake contributes to sustained resting energy expenditure despite a negative energy balance. Higher protein intake changes body composition in a way that spares fat free mass at the cost of fat mass (78-80). Since fat free mass is a major determinant of resting energy expenditure, preservation of fat free mass during weight loss or weight maintenance contributes to a sustained resting energy expenditure $(81,82)$. At a high protein intake there is a relatively large metabolic inefficiency with respect to weight gain, which is related to body composition. The energy costs to build fat free body mass are higher than the energy costs to build fat mass. Thus, due to the sparing of fat free mass the energy costs for weight gain are higher (83-85). Both a protein-induced increase in energy expenditure and a fat free mass sparing effect have an important contribution to the effectiveness of high protein diets for weight loss and weight maintenance.

\section{IMPLICATIONS OF PROTEIN INTAKE FOR ENERGY BALANCE}

Dietary proteins have a significant effect on energy intake: some proteins reduce energy intake at a meal 3 hours later with about $20 \%$. It appears that it is not necessarily high protein intake that suppresses appetite. Already at a normal protein concentration alpha-lactalbumin, gelatin, and gelatin with added TRP reduce subsequent energy intake to the same extent as a high protein meal (6). With respect to the longer term, Weigle et al. showed that when an ad libitum high protein diet was consumed for several weeks, energy intake was reduced with $\sim 15 \%$ while satiety was sustained at a comfortable level (86). At the same time, a high protein diet increases energy expenditure with $3-5 \%$ compared with a normal protein diet $(8,51,66)$. The extent to which energy expenditure increases depends on the protein type in the diet $(73,74)$. During a weight loss or weight maintenance diet a reduced energy intake does not need to happen spontaneously. Hence, sustained protein-induced satiety during an energy reduced weight loss or weight maintenance diet may enhance compliance to the diet $(78,79,86)$. Reductions in body weight have been shown with high protein diets in ad libitum studies but not in isoenergetic studies $(80,85)$, suggesting that the effect of dietary protein on satiety is of relatively more significance for weight loss and weight maintenance than a protein-induced increase in energy expenditure. However, in relation to the fat free mass sparing effect and prevention of weight cycling the protein-induced increase in energy expenditure is indispensable.

Proteins with a low quality, i.e. those who are (relatively) lacking essential amino acids, suppress hunger and may be used for weight loss snacks to reduce energy intake and reduce hunger. In order to provide all essential amino acids in the right amounts, 'complete' proteins are essential. Proteins which increase postprandial amino acid concentrations increase satiety and postpone the next eating episode. These types of protein may be used in a weight maintenance diet to 
sustain satiety. Alpha-lactalbumin is a 'complete' protein which is highly satiating compared with other types of protein and is potentially a good type of protein to use. Moreover, with respect to the stimulation of energy expenditure by increased protein synthesis, as is suggested to happen with 'complete' proteins, alpha-lactalbumin may be a good protein type for weight loss or weight maintenance diets too.

Especially in relation to the preservation of fat free mass during weight loss or weight maintenance, an increase in energy expenditure is an important effect of high protein intake. Gluconeogenesis contributes substantially to increased energy expenditure after a high protein diet and an increase in gluconeogenesis will increase energy expenditure. Stimulation of gluconeogenesis by a high protein diet with a high glucogenic amino acid content may be used to achieve this. As ketogenic amino acids appear to increase satiety whereas glucogenic amino acids may increase energy expenditure, the choice for a relatively more ketogenic or glucogenic type of protein depends on the purpose of the diet. For instance, a relatively more glucogenic type of protein may be used in a weight maintenance diet to stimulate energy expenditure and the fat free mass sparing effect. Although they affect the energy balance differently, both glucogenic and ketogenic types of protein have beneficial effects for weight loss and weight maintenance diets.

\section{CONCLUSIONS}

With respect to the explanation of relatively increased satiety induced by (high) protein meals or diets, evidence was found for three mechanisms that coincided with or related to proteininduced satiety. Firstly, according to the 'amino static' theory, postprandial increases of amino acids, such as branched-chain amino acids, taurine, and lysine with casein, soy, and whey respectively, may be directed into brain signaling for satiety. There is no group of amino acids that is generally directly related to appetite suppression. Secondly, according to the 'indispensable amino acid deficiency' theory, increases in non-essential amino acids in combination with relatively lower concentrations of essential amino acids, such as with gelatin, may prevent subjects from further ingestion of a meal that leads to deficiency of essential amino acids, thus creating further hunger suppression. Thirdly, a ketogenic state with a high protein, high fat, carbohydrate-free diet induces a high fat oxidation, increased ketone bodies, and appetite suppression. This is enhanced by ketogenic amino acids. Furthermore, no evidence was found for the hypothesis that protein-induced satiety is attributed to (an)orexigenic hormones. Regarding effects of high protein diets on energy expenditure, it is concluded that a high protein diet increases energy expenditure irrespective of the proportion of the other macronutrients in the diet. This increase is for nearly $50 \%$ explained by increased gluconeogenesis. These observations and explanations enhance knowledge on the way metabolic targets are stimulated by dietary proteins and how this contributes to body weight loss and weight maintenance. 


\section{FUTURE RESEARCH SUGGESTIONS}

The studies in this thesis show that differences in satiating efficacies may be attributed to differences in amino acid composition and postprandial amino acid responses. As plasma amino acid concentrations are partly determined by splanchnic extraction and the continuous breakdown and (re)synthesis of proteins, the question remains whether different amounts and types of protein affect these processes differently. Using stable isotope techniques to measure splanchnic extraction, protein breakdown, and protein synthesis will provide more information on the effect of protein metabolism on the control of food intake. Another finding presented in this thesis is that the increased energy expenditure after a high protein diet is partly attributable to increased gluconeogenesis. The question remains what the contribution of other processes in protein metabolism, e.g. protein oxidation, ureagenesis, and protein synthesis, to energy expenditure is. Again, stable isotope techniques should be combined with measurement of energy expenditure to study the relationship between protein metabolism and energy expenditure. Taken together, studying whole-body and tissue specific protein metabolism both in the fed and in the fasted state after intake of different types of protein in different concentrations may enhance understanding of the thermogenic and satiating properties of protein.

Regarding protein characteristics and mechanisms contributing to protein-induced satiety several aspects remain to be elucidated. A potential mechanism that was shown to contribute to satiety is an increased dietary fat oxidation and ketone body concentration. It requires further examination whether the concentration of ketone bodies can be increased by specific types of protein and how this increases satiety. On the other hand, effects of specific types of protein with a certain amino acid composition on energy expenditure should be tested. For instance, the question whether a protein with a glucogenic amino acid composition additionally stimulates energy expenditure requires further study. Moreover, as alpha-lactalbumin is a complete protein it is of interest to study the effects of alpha-lactalbumin on protein synthesis and energy expenditure.

In addition to the relatively short term effects of high protein intake, the long term effects of high protein intake on protein metabolism, energy expenditure, and (changes in) body composition require further study. A positive protein balance has been shown with a high protein diet in energy balance for a few days, however, it is not known if this is a permanent effect that is present in the long term as well. Moreover, it remains to be established whether an increased protein balance actually results in increased protein synthesis. A positive protein balance points into the direction of increased protein synthesis, however, this has not been quantified so far. Increased protein synthesis probably contributes to the formation of fat free body mass, hence the exact contribution of increased protein synthesis to the formation and preservation of fat free mass should be measured. A next step would be to study these processes in subjects who are in a negative energy balance with a high protein weight loss diet. As an increased protein turnover may be responsible for sustained energy expenditure despite a negative energy balance that has been shown with high protein diets, effects of a high protein diet in negative energy balance on protein turnover should be measured. Again, the contribution of increased protein synthesis to the sparing of fat free body mass requires quantification in a 
situation of negative energy balance. Thus, important questions regarding long term effects of high protein diets on protein turnover remain to be studied. Measurements of protein metabolism, energy expenditure, and body composition will provide more insight in the underlying mechanisms accompanying the beneficial effects of high protein diets for weight loss and weight maintenance.

\section{REFERENCES}

1. Veldhorst MA, Nieuwenhuizen AG, Hochstenbach-Waelen A, et al. Comparison of the effects of a high- and normal-casein breakfast on satiety, 'satiety' hormones, plasma amino acids and subsequent energy intake. Br J Nutr 2009;101:295-303.

2. Veldhorst MA, Nieuwenhuizen AG, Hochstenbach-Waelen A, et al. Effects of high and normal soyprotein breakfasts on satiety and subsequent energy intake, including amino acid and 'satiety' hormone responses. Eur J Nutr 2009;48:92-100.

3. Veldhorst M, Smeets A, Soenen S, et al. Protein-induced satiety: Effects and mechanisms of different proteins. Physiol Behav 2008;94:300-7.

4. Veldhorst MA, Nieuwenhuizen AG, Hochstenbach-Waelen A, et al. Effects of complete whey-protein breakfasts versus whey without GMP-breakfasts on energy intake and satiety. Appetite 2009;52:388-95.

5. Veldhorst MA, Nieuwenhuizen AG, Hochstenbach-Waelen A, et al. Dose-dependent satiating effect of whey relative to casein or soy. Physiol Behav 2009;96:675-82.

6. Veldhorst MA, Nieuwenhuizen AG, Hochstenbach-Waelen A, et al. A breakfast with alpha-lactalbumin, gelatin, or gelatin + TRP lowers energy intake at lunch compared with a breakfast with casein, soy, whey, or whey-GMP. Clin Nutr 2009;28:147-55.

7. Veldhorst MAB, Westerterp KR, van Vught AJAH, Westerterp-Plantenga MS. Protein-induced appetite suppression is affected by the presence or absence of carbohydrates. submitted for publication 2009.

8. Veldhorst MAB, Westerterp-Plantenga MS, Westerterp KR. Gluconeogenesis and energy expenditure after a high protein, carbohydrate-free diet. Am J Clin Nutr 2009;90:519-526.

9. Nieuwenhuizen AG, Hochstenbach-Waelen A, Veldhorst MA, et al. Acute effects of breakfasts containing alphalactalbumin, or gelatin with or without added tryptophan, on hunger, 'satiety' hormones and amino acid profiles. Br J Nutr 2009;101:1859-66.

10. Mellinkoff SM, Frankland M, Boyle D, Greipel M. Relationship between serum amino acid concentration and fluctuations in appetite. J Appl Physiol 1956;8:535-8.

11. Lenard NR, Berthoud HR. Central and peripheral regulation of food intake and physical activity: pathways and genes. Obesity (Silver Spring) 2008;16 Suppl 3:S11-22.

12. Faipoux R, Tome D, Gougis S, Darcel N, Fromentin G. Proteins activate satiety-related neuronal pathways in the brainstem and hypothalamus of rats. J Nutr 2008;138:1172-8.

13. Morrison CD, Xi X, White CL, Ye J, Martin RJ. Amino acids inhibit Agrp gene expression via an mTOR-dependent mechanism. Am J Physiol Endocrinol Metab 2007;293:E165-71.

14. Ropelle ER, Pauli JR, Fernandes MF, et al. A central role for neuronal AMP-activated protein kinase (AMPK) and mammalian target of rapamycin (mTOR) in high-protein diet-induced weight loss. Diabetes 2008;57:594-605.

15. Cota D, Proulx K, Smith KA, et al. Hypothalamic mTOR signaling regulates food intake. Science 2006;312:927-30.

16. Bowen J, Noakes M, Clifton PM. Appetite regulatory hormone responses to various dietary proteins differ by body mass index status despite similar reductions in ad libitum energy intake. J Clin Endocrinol Metab 2006;91:2913-9.

17. Bowen J, Noakes M, Trenerry C, Clifton PM. Energy intake, ghrelin, and cholecystokinin after different carbohydrate and protein preloads in overweight men. J Clin Endocrinol Metab 2006;91:1477-83.

18. Burton-Freeman BM. Glycomacropeptide (GMP) is not critical to whey-induced satiety, but may have a unique role in energy intake regulation through cholecystokinin (CCK). Physiol Behav 2008;93:379-87.

19. Boirie Y, Dangin M, Gachon P, Vasson MP, Maubois JL, Beaufrere B. Slow and fast dietary proteins differently modulate postprandial protein accretion. Proc Natl Acad Sci U S A 1997;94:14930-5.

20. Mahe S, Roos N, Benamouzig R, et al. Gastrojejunal kinetics and the digestion of [15N]beta-lactoglobulin and casein in humans: the influence of the nature and quantity of the protein. Am J Clin Nutr 1996;63:546-52.

21. Dangin M, Boirie Y, Garcia-Rodenas C, et al. The digestion rate of protein is an independent regulating factor of postprandial protein retention. Am J Physiol Endocrinol Metab 2001;280:E340-8.

22. Dangin M, Boirie $\mathrm{Y}$, Guillet C, Beaufrere B. Influence of the protein digestion rate on protein turnover in young and elderly subjects. J Nutr 2002;132:3228S-33S.

23. Hall WL, Millward DJ, Long SJ, Morgan LM. Casein and whey exert different effects on plasma amino acid profiles, gastrointestinal hormone secretion and appetite. Br J Nutr 2003;89:239-48. 
Thut PD, Hruska RE, Huxtable RJ, Bressler R. Taurine, edited by R.J. Huxtable and A. Barbeau. 1976:357-364. Fujihira E, Takahashi H, Nakazawa M. Effect of long-term feeding of taurine in hereditary hyperglycemic obese mice. Chem Pharm Bull (Tokyo) 1970;18:1636-42.

Zhang M, Bi LF, Fang JH, et al. Beneficial effects of taurine on serum lipids in overweight or obese non-diabetic subjects. Amino Acids 2004;26:267-71.

Laidlaw SA, Grosvenor M, Kopple JD. The taurine content of common foodstuffs. JPEN J Parenter Enteral Nutr 1990;14:183-8.

Uhe AM, Collier GR, O'Dea K. A comparison of the effects of beef, chicken and fish protein on satiety and amino acid profiles in lean male subjects. J Nutr 1992;122:467-72.

Huxtable RJ. Physiological actions of taurine. Physiol Rev 1992;72:101-63.

Birdsall TC. Therapeutic applications of taurine. Altern Med Rev 1998;3:128-36.

Beulens JW, Bindels JG, de Graaf C, Alles MS, Wouters-Wesseling W. Alpha-lactalbumin combined with a regular diet increases plasma Trp-LNAA ratio. Physiol Behav 2004;81:585-93.

Leibowitz SF, Alexander JT. Hypothalamic serotonin in control of eating behavior, meal size, and body weight. Biol Psychiatry 1998;44:851-64.

Wurtman RJ, Wurtman JJ. Do carbohydrates affect food intake via neurotransmitter activity? Appetite 1988;11 Suppl 1:42-7.

Halford JC, Harrold JA, Boyland EJ, Lawton CL, Blundell JE. Serotonergic drugs : effects on appetite expression and use for the treatment of obesity. Drugs 2007;67:27-55.

Toornvliet AC, Pijl H, Hopman E, Elte-de Wever BM, Meinders AE. Serotoninergic drug-induced weight loss in carbohydrate craving obese patients. Int J Obes Relat Metab Disord 1996;20:917-20.

Millward DJ, Layman DK, Tome D, Schaafsma G. Protein quality assessment: impact of expanding understanding of protein and amino acid needs for optimal health. Am J Clin Nutr 2008;87:1576S-1581S.

Gietzen DW, Hao S, Anthony TG. Mechanisms of food intake repression in indispensable amino acid deficiency. Annu Rev Nutr 2007;27:63-78.

Leung PM, Rogers QR. Importance of prepyriform cortex in food-intake response of rats to amino acids. Am J Physiol 1971;221:929-35.

Langhans W. Fatty acid oxidation in the energostatic control of eating--a new idea. Appetite 2008;51:446-51. Leonhardt M, Langhans W. Fatty acid oxidation and control of food intake. Physiol Behav 2004;83:645-51.

Scharrer E. Control of food intake by fatty acid oxidation and ketogenesis. Nutrition 1999;15:704-14.

Kahler A, Zimmermann M, Langhans W. Suppression of hepatic fatty acid oxidation and food intake in men. Nutrition 1999;15:819-28.

Scharrer E, Langhans W. Control of food intake by fatty acid oxidation. Am J Physiol 1986;250:R1003-6.

Robinson AM, Williamson DH. Physiological roles of ketone bodies as substrates and signals in mammalian tissues. Physiol Rev 1980;60:143-87.

Arase K, Fisler JS, Shargill NS, York DA, Bray GA. Intracerebroventricular infusions of 3-OHB and insulin in a rat model of dietary obesity. Am J Physiol 1988;255:R974-81.

Fisler JS, Egawa M, Bray GA. Peripheral 3-hydroxybutyrate and food intake in a model of dietary-fat induced obesity: effect of vagotomy. Physiol Behav 1995;58:1-7.

Johnstone AM, Horgan GW, Murison SD, Bremner DM, Lobley GE. Effects of a high-protein ketogenic diet on hunger, appetite, and weight loss in obese men feeding ad libitum. Am J Clin Nutr 2008;87:44-55.

Boden G, Sargrad K, Homko C, Mozzoli M, Stein TP. Effect of a low-carbohydrate diet on appetite, blood glucose levels, and insulin resistance in obese patients with type 2 diabetes. Ann Intern Med 2005;142:403-11.

Stryer L. Biochemistry. New York: W.H. Freeman and Company, 1999.

Batterham RL, Heffron $\mathrm{H}$, Kapoor S, et al. Critical role for peptide $\mathrm{YY}$ in protein-mediated satiation and bodyweight regulation. Cell Metab 2006;4:223-33.

Lejeune MP, Westerterp KR, Adam TC, Luscombe-Marsh ND, Westerterp-Plantenga MS. Ghrelin and glucagonlike peptide 1 concentrations, 24-h satiety, and energy and substrate metabolism during a high-protein diet and measured in a respiration chamber. Am J Clin Nutr 2006;83:89-94.

Anderson GH, Tecimer SN, Shah D, Zafar TA. Protein source, quantity, and time of consumption determine the effect of proteins on short-term food intake in young men. J Nutr 2004;134:3011-5.

Potier M, Darcel N, Tome D. Protein, amino acids and the control of food intake. Curr Opin Clin Nutr Metab Care 2009;12:54-8.

Tome D. Protein, amino acids and the control of food intake. Br J Nutr 2004;92 Suppl 1:S27-30.

Calbet JA, MacLean DA. Plasma glucagon and insulin responses depend on the rate
acids after ingestion of different protein solutions in humans. J Nutr 2002;132:2174-82. van Loon $\amalg$, Saris WH, Verhagen H, Wagenmakers AJ. Plasma insulin responses after ingestion of different amino acid or protein mixtures with carbohydrate. Am J Clin Nutr 2000;72:96-105.

7. Frid AH, Nilsson M, Holst JJ, Bjorck IM. Effect of whey on blood glucose and insulin responses to composite breakfast and lunch meals in type 2 diabetic subjects. Am J Clin Nutr 2005;82:69-75.

Nilsson M, Stenberg M, Frid AH, Holst JJ, Bjorck IM. Glycemia and insulinemia in healthy subjects after lactoseequivalent meals of milk and other food proteins: the role of plasma amino acids and incretins. Am J Clin Nutr 2004;80:1246-53. 
59. Gunnarsson PT, Winzell MS, Deacon CF, et al. Glucose-induced incretin hormone release and inactivation are differently modulated by oral fat and protein in mice. Endocrinology 2006;147:3173-80.

60. Kieffer TJ, Habener JF. The glucagon-like peptides. Endocr Rev 1999;20:876-913.

61. Holst JJ. Glucagon-like Peptide 1 (GLP-1): An Intestinal Hormone, Signalling Nutritional Abundance, with an Unusual Therapeutic Potential. Trends Endocrinol Metab 1999;10:229-235.

62. Flint A, Raben A, Astrup A, Holst JJ. Glucagon-like peptide 1 promotes satiety and suppresses energy intake in humans. J Clin Invest 1998;101:515-20.

63. Gelling RW, Overduin J, Morrison CD, et al. Effect of uncontrolled diabetes on plasma ghrelin concentrations and ghrelin-induced feeding. Endocrinology 2004;145:4575-82.

64. Lang V, Bellisle F, Alamowitch C, et al. Varying the protein source in mixed meal modifies glucose, insulin and glucagon kinetics in healthy men, has weak effects on subjective satiety and fails to affect food intake. Eur J Clin Nutr 1999;53:959-65.

65. Lang V, Bellisle F, Oppert JM, et al. Satiating effect of proteins in healthy subjects: a comparison of egg albumin, casein, gelatin, soy protein, pea protein, and wheat gluten. Am J Clin Nutr 1998;67:1197-204.

66. Hochstenbach-Waelen A, Veldhorst MA, Nieuwenhuizen AG, Westerterp-Plantenga MS, Westerterp KR. Comparison of 2 diets with either $25 \%$ or $10 \%$ of energy as casein on energy expenditure, substrate balance, and appetite profile. Am J Clin Nutr 2009;89:831-8.

67. Crovetti R, Porrini M, Santangelo A, Testolin G. The influence of thermic effect of food on satiety. Eur J Clin Nutr 1998;52:482-8.

68. Johnston CS, Day CS, Swan PD. Postprandial thermogenesis is increased $100 \%$ on a high-protein, low-fat diet versus a high-carbohydrate, low-fat diet in healthy, young women. J Am Coll Nutr 2002;21:55-61.

69. Raben A, Agerholm-Larsen L, Flint A, Holst JJ, Astrup A. Meals with similar energy densities but rich in protein, fat, carbohydrate, or alcohol have different effects on energy expenditure and substrate metabolism but not on appetite and energy intake. Am J Clin Nutr 2003;77:91-100.

70. Westerterp KR, Wilson SA, Rolland V. Diet induced thermogenesis measured over 24h in a respiration chamber: effect of diet composition. Int J Obes Relat Metab Disord 1999;23:287-92.

71. Westerterp-Plantenga MS, Rolland V, Wilson SA, Westerterp KR. Satiety related to $24 \mathrm{~h}$ diet-induced thermogenesis during high protein/carbohydrate vs high fat diets measured in a respiration chamber. Eur J Clin Nutr 1999;53:495-502.

72.

Tappy L. Thermic effect of food and sympathetic nervous system activity in humans. Reprod Nutr Dev 1996;36:391-7.

73. Mikkelsen PB, Toubro S, Astrup A. Effect of fat-reduced diets on 24-h energy expenditure: comparisons between animal protein, vegetable protein, and carbohydrate. Am J Clin Nutr 2000;72:1135-41.

74. Pannemans DL, Wagenmakers AJ, Westerterp KR, Schaafsma G, Halliday D. Effect of protein source and quantity on protein metabolism in elderly women. Am J Clin Nutr 1998;68:1228-35.

75. Hall KD. Computational model of in vivo human energy metabolism during semistarvation and refeeding. Am J Physiol Endocrinol Metab 2006;291:E23-37.

76. van Milgen J. Modeling biochemical aspects of energy metabolism in mammals. J Nutr 2002;132:3195-202.

77. Pitkanen O, Takala J, Poyhonen M, Kari A. Branched-chain and mixed amino acid solutions and thermogenesis in postoperative patients. Nutrition 1994;10:132-7.

78. Lejeune MP, Kovacs EM, Westerterp-Plantenga MS. Additional protein intake limits weight regain after weight loss in humans. Br J Nutr 2005;93:281-9.

79. Westerterp-Plantenga MS, Lejeune MP, Nijs I, van Ooijen M, Kovacs EM. High protein intake sustains weight maintenance after body weight loss in humans. Int J Obes Relat Metab Disord 2004;28:57-64.

80. Westerterp-Plantenga MS, Luscombe-Marsh N, Lejeune MP, et al. Dietary protein, metabolism, and bodyweight regulation: dose-response effects. Int J Obes (Lond) 2006;30 Suppl 3:S16-23.

81. Ravussin E, Bogardus C. Relationship of genetics, age, and physical fitness to daily energy expenditure and fuel utilization. Am J Clin Nutr 1989;49:968-75.

82. Westerterp KR. Energy expenditure. In: Westerterp-Plantenga MS, Fredrix EWHM, Steffens AB, eds. Food intake and energy expenditure: CRC Press, 1994:235-257.

83. Stock MJ. Gluttony and thermogenesis revisited. Int J Obes Relat Metab Disord 1999;23:1105-17.

84. Pullar JD, Webster AJ. The energy cost of fat and protein deposition in the rat. Br J Nutr 1977;37:355-63.

85. Westerterp-Plantenga MS, Nieuwenhuizen A, Tome D, Soenen S, Westerterp KR. Dietary protein, weight loss, and weight maintenance. Annu Rev Nutr 2009;29:21-41.

86. Weigle DS, Breen PA, Matthys CC, et al. A high-protein diet induces sustained reductions in appetite, ad libitum caloric intake, and body weight despite compensatory changes in diurnal plasma leptin and ghrelin concentrations. Am J Clin Nutr 2005;82:41-8. 
Summary 

Overweight and obesity have become a major health problem and strategies for prevention and treatment are needed. Relatively high protein diets have been shown to be an effective tool for body weight loss and weight maintenance after weight loss. A protein intake above $15 \%$ of energy from protein can be regarded as high, whereas a protein intake between 10 and $15 \%$ of energy can be considered as normal protein intake. High protein diets appear to favorably affect both sides of the energy balance, i.e. they increase postprandial and post-absorptive satiety and thereby reduce energy intake and they elevate energy expenditure. The studies that are described in the first chapters of this thesis test the hypothesis that regardless of the type of protein, high protein meals are more satiating than normal protein meals. This was shown to be the case for casein and soy but not whey: a high casein- or soy-breakfast was $10-15 \%$ more satiating than a normal casein- or soy-breakfast, respectively. A second hypothesis that was tested was that an increased protein-induced satiety can be attributed to a larger response of postprandial (an)orexigenic hormones. Differences in satiety appeared not to be directly related to differences in concentrations of the (an)orexigenic hormones GLP-1, insulin, or ghrelin. Some evidence was found for an alternative hypothesis for increased satiety after high protein meals, i.e. the 'amino static' theory that states that increased postprandial amino acid concentrations are directed into brain signaling for satiety. For instance, after a high casein-breakfast the increased satiety coincided with prolonged elevated concentrations of amino acids. With respect to the question whether different types of protein have different satiating efficacies it was shown that alpha-lactalbumin, gelatin, and gelatin with added tryptophan (TRP) reduce hunger with about $40 \%$ compared with casein, soy, whey, or whey without glycomacropeptide (GMP) and induce a related $20 \%$ reduction of subsequent energy intake. Whey was about $15 \%$ more satiating than casein or soy. The presence of GMP appears to be essential for the satiating effect of whey: a breakfast with whey with GMP reduced energy intake at lunch with about $300 \mathrm{~kJ}$ compared with a breakfast with whey without GMP. The hunger suppressive effect of gelatin and gelatin with added TRP may be explained by the 'indispensable amino acid deficiency' theory that states that increases in non-essential amino acids in combination with relatively lower concentrations of essential amino acids, may prevent subjects from further ingestion of a meal that leads to deficiency of essential amino acids, thus creating further hunger suppression. The appetite suppressive effect of alpha-lactalbumin and whey may be attributed to the relatively high content of the ketogenic amino acids lysine and leucine; a ketogenic state appears to enhance the appetite suppressive effect of high proteins meals or diets (chapters 2-7).

Subsequently it was studied whether the presence or absence of a normal proportion of carbohydrates in a high protein diet is of significance for affecting appetite, energy expenditure, and fat oxidation. Comparing effects of a high protein diet with a normal proportion of carbohydrates or a normal protein diet in one group and a high protein, carbohydrate-free diet or a normal protein diet in another group of healthy normal-weight subjects in energy balance showed that a high protein diet suppressed appetite on average $10 \%$ more compared with a normal protein diet. In addition, appetite suppression was $27 \%$ higher after a high protein, carbohydrate-free diet compared with a high protein diet with a normal proportion of carbohydrates. The $24 \mathrm{~h}$ respiratory quotient was reduced after the high protein diet with a normal proportion of carbohydrates compared with the normal protein diet $(0.81 \pm 0.02$ vs. 0.86 \pm 0.02 ) and was reduced after the high protein, carbohydrate-free diet compared with the normal protein diet $(0.76 \pm 0.01$ vs. $0.85 \pm 0.02)$; the respiratory quotient was significantly lower 
after the high protein, carbohydrate-free diet than after the high protein diet with a normal proportion of carbohydrates. The $\beta$-hydroxybutyrate concentration was increased after the high protein diet with a normal proportion of carbohydrates compared with the normal protein diet (332 $\pm 102 \mu \mathrm{mol} / \mathrm{l}$ vs. $228 \pm 88 \mu \mathrm{mol} / \mathrm{l}$ ) and was increased after the high protein, carbohydratefree diet compared with the normal protein diet $(1349 \pm 653 \mu \mathrm{mol} / \mathrm{l}$ vs. $234 \pm 226 \mu \mathrm{mol} / \mathrm{l})$; the $\beta$ hydroxybutyrate concentration was significantly higher after the high protein, carbohydrate-free diet than after the high protein diet with a normal proportion of carbohydrates. Thus, the absence of a normal proportion of carbohydrates in a high protein diet increases appetite suppression and fat oxidation, suggesting that a ketogenic state contributes to the increased appetite suppression after a high protein diet without a normal proportion of carbohydrates. Energy expenditure was $4 \%$ increased after a high protein diet compared with a normal protein diet, but was not affected differently by the presence or absence of a normal proportion of carbohydrates in a high protein diet (chapter 8).

Finally, the hypothesis that increased energy expenditure at a high protein diet can be attributed to increased gluconeogenesis was tested in healthy, normal weight male subjects who consumed a high protein, carbohydrate-free diet or a normal protein diet in energy balance after performing an exhaustive glycogen-lowering exercise test. The increase in energy expenditure after the high protein, carbohydrate-free diet compared with the normal protein diet $(0.34 \pm$ $0.13 \mathrm{MJ} / \mathrm{d}$ ) was a function of the increase in gluconeogenesis $\left(r=0.70, R^{2}=0.49\right): 42 \%$ of the increase in energy expenditure was explained by the increase in gluconeogenesis. The energy costs of gluconeogenesis were one third of the energy content of glucose produced (chapter 9). Taken together, these studies support three mechanisms that coincide with or relate to proteininduced satiety. Firstly, according to the 'amino static' theory, postprandial increases of amino acids, such as branched-chain amino acids, taurine, and lysine with casein, soy, and whey respectively, may be directed into brain signaling for satiety. There is no group of amino acids that is generally directly related to appetite suppression. Secondly, according to the 'indispensable amino acid deficiency' theory, increases in non-essential amino acids in combination with relatively lower concentrations of essential amino acids, such as with gelatin, may prevent subjects from further ingestion of a meal that leads to deficiency of essential amino acids, thus creating further hunger suppression. Thirdly, a ketogenic state with a high protein, high fat, carbohydrate-free diet induces a high fat oxidation, increased ketone bodies, and appetite suppression. This is enhanced by ketogenic amino acids. Furthermore, no evidence was found for the hypothesis that protein-induced satiety is attributed to (an)orexigenic hormones. Regarding effects of high protein diets on energy expenditure, it is concluded that a high protein diet increases energy expenditure irrespective of the proportion of the other macronutrients in the diet. This increase is for nearly $50 \%$ explained by increased gluconeogenesis. These observations and explanations enhance knowledge on the way metabolic targets are stimulated by dietary proteins and how this contributes to body weight loss and weight maintenance. 
Samenvatting 

Overgewicht en obesitas vormen een groot gezondheidsprobleem waarvoor preventie- en behandelstrategieën nodig zijn. Diëten met een relatief hoog eiwitgehalte zijn een effectief middel voor gewichtsverlies en gewichtsbehoud na gewichtsverlies omdat zij een gunstig effect hebben op beide zijden van de energiebalans. Een eiwitinname hoger dan 15 energieprocent wordt beschouwd als hoog, terwijl een eiwitinname van 10-15 energieprocent gezien wordt als een normale eiwitinname. Enerzijds verhogen hoog-eiwit diëten de postprandiale en postabsorptieve verzadiging en verlagen daarmee de energie-inname en anderzijds stimuleren ze het energiegebruik. De studies beschreven in de eerste hoofdstukken van dit proefschrift toetsen de hypothese dat, ongeacht het soort eiwit, een hoog-eiwit maaltijd meer verzadigend is dan een maaltijd met een normale hoeveelheid eiwit. Dit blijkt te gelden voor caseïne en soja, maar niet voor wei: een hoog-caseïne- of soja-ontbijt was $10-15 \%$ meer verzadigend dan een normal-caseïne- of soja-ontbijt. De tweede hypothese die werd getoetst is dat een verhoogde eiwit-geïnduceerde verzadiging wordt veroorzaakt door een sterkere stijging of daling van de postprandiale concentratie van (an)orexigene hormonen. Echter, verschillen in verzadiging waren niet gerelateerd aan verschillen in postprandiale concentraties van (an)orexigene hormonen zoals GLP-1, insuline of ghreline. Er zijn wel aanwijzingen voor een alternatieve hypothese, namelijk de 'aminostatische' hypothese die stelt dat verhoogde postprandiale concentraties van aminozuren in de hersenen leiden tot signalering van verzadiging. Na een hoog-caseïne ontbijt viel de verhoogde verzadiging bijvoorbeeld samen met verhoogde concentraties van aminozuren. Met betrekking tot de vraag of verschillende soorten eiwitten een verschillende mate van eetlust-onderdrukking induceren blijkt dat alfa-lactalbumine, gelatine en gelatine waaraan tryptofaan (TRP) is toegevoegd de honger met circa $40 \%$ reduceren ten opzichte van caseïne, soja, wei en wei zonder glycomacropeptide (GMP) en, hieraan gerelateerd, zij reduceren de voedselinname bij een volgende maaltijd met $20 \%$. Daarnaast blijkt wei ongeveer $15 \%$ meer verzadigend te zijn dan caseïne of soja; na een ontbijt met wei met GMP was de energie-inname bij de lunch circa $300 \mathrm{~kJ}$ lager dan na een ontbijt met wei zonder GMP. De aanwezigheid van GMP lijkt dus noodzakelijk te zijn voor het verzadigende effect van wei. Het honger-onderdrukkende effect van gelatine en gelatine met TRP kan verklaard worden door de 'essentiële aminozuren deficiëntie' hypothese die stelt dat een stijging in niet-essentiële aminozuren in combinatie met relatief lage concentraties van essentiële aminozuren na consumptie van een incompleet eiwit, voorkomt dat verder gegeten wordt van een dieet dat leidt tot deficiëntie van essentiële aminozuren, wat resulteert in verdere honger-onderdrukking. Het eetlust-onderdrukkende effect van alfa-lactalbumine en wei kan worden toegeschreven aan het relatief hoge gehalte ketogene aminozuren leucine en lysine: een ketogene staat van het lichaam versterkt het eetlust-onderdrukkende effect van hoog-eiwit maaltijden of diëten (hoofdstuk 2-7).

Vervolgens werd onderzocht of in een hoog-eiwit dieet de aan- of afwezigheid van een normale hoeveelheid koolhydraten van belang is voor de effecten op eetlust, energiegebruik en vetoxidatie in 2 groepen gezonde proefpersonen met een normaal gewicht die óf een hoog-eiwit dieet met een normale hoeveelheid koolhydraten en een normaal-eiwit dieet óf een hoog-eiwit, koolhydraat-vrij dieet en een normaal-eiwit dieet consumeerden. Een hoog-eiwit dieet onderdrukte de eetlust circa $10 \%$ meer dan een normaal-eiwit dieet terwijl de eetlust onderdrukking $27 \%$ sterker was na een hoog-eiwit, koolhydraat-vrij dieet dan na een hoog-eiwit dieet met een normale hoeveelheid koolhydraten. Het 24-uur respiratoir quotiënt was lager na 
een hoog-eiwit dieet met een normale hoeveelheid koolhydraten dan na een normaal-eiwit dieet $(0.81 \pm 0.02$ vs. $0.86 \pm 0.02)$ en was lager na een hoog-eiwit, koolhydraat-vrij dieet dan na een normaal-eiwit dieet $(0.76 \pm 0.01$ vs. $0.85 \pm 0.02)$; het respiratoir quotiënt was significant lager na een hoog-eiwit, koolhydraat-vrij dieet dan na een hoog-eiwit dieet met een normale hoeveelheid koolhydraten. De $\beta$-hydroxybutyraat concentratie was hoger na een hoog-eiwit diet met een normale hoeveelheid koolhydraten dan na een normaal-eiwit dieet $(332 \pm 102 \mu \mathrm{mol} / \mathrm{l}$ vs. $228 \pm 88 \mu \mathrm{mol} / \mathrm{l})$ en was hoger na een hoog-eiwit, koolhydraat-vrij dieet dan na een normaaleiwit dieet $(1349 \pm 653 \mu \mathrm{mol} / \mathrm{l}$ vs. $234 \pm 226 \mu \mathrm{mol} / \mathrm{l})$; de $\beta$-hydroxybutyraat concentratie was significant hoger na een hoog-eiwit, koolhydraat-vrij dieet dan na een hoog-eiwit dieet met een normale hoeveelheid koolhydraten. De afwezigheid van een normale hoeveelheid koolhydraten in een hoog-eiwit dieet versterkt het eetlust-onderdrukkende effect en verhoogt de vetoxidatie. De resultaten suggereren dat een ketogene staat bijdraagt aan het eetlust-onderdrukkende effect van een hoog-eiwit, koolhydraat-vrij dieet. Het energiegebruik was $4 \%$ hoger na een hoogeiwit dieet; de aan- of afwezigheid van een normale hoeveelheid koolhydraten had geen effect op het energiegebruik (hoofdstuk 8).

Tenslotte werd de hypothese dat een verhoogd energiegebruik na een hoog-eiwit dieet kan worden toegeschreven aan een verhoogde gluconeogenese getoetst in gezonde mannen met een normaal gewicht die een hoog-eiwit, koolhydraat-vrij dieet of een normaal-eiwit dieet consumeerden na een glycogeen-verlagende inspanningstest. De stijging van het energiegebruik na het hoog-eiwit, koolhydraat-vrij dieet in vergelijking met het normaal-eiwit dieet $(0.34 \pm 0.13$ $\mathrm{MJ} / \mathrm{d}$ ) was een functie van de stijging van de gluconeogenese $\left(r=0.70, R^{2}=0.49\right): 42 \%$ van de stijging van het energiegebruik werd verklaard door de stijging in gluconeogenese. De energiekosten van gluconeogenese waren een derde van de energie-inhoud van de gevormde glucose (hoofdstuk 9).

Samengevat wijzen deze studies op drie mechanismen die samenvallen met of gerelateerd zijn aan eiwit-geïnduceerde verzadiging. Ten eerste zal, volgens de 'aminostatische' hypothese, een stijging van postprandiale concentraties van aminozuren, zoals vertakte keten aminozuren, taurine en lysine met respectievelijk caseïne, soja en wei, in de hersenen leiden tot signalering van verzadiging. $\mathrm{Er}$ is geen groep aminozuren die in het algemeen direct gerelateerd is aan eetlust-onderdrukking. Ten tweede zal, volgens de 'essentiële aminozuren deficiëntie' hypothese, een stijging in niet-essentiële aminozuren in combinatie met relatief lage concentraties van essentiële aminozuren, zoals na consumptie van gelatine, voorkomen dat verder gegeten wordt van een dieet dat leidt tot deficiëntie van essentiële aminozuren, wat resulteert in verdere honger-onderdrukking. Ten derde leidt een ketogene staat na een hoogeiwit, hoog-vet, koolhydraat-vrij dieet tot een verhoogde vetoxidatie, een verhoogde concentratie van ketonlichamen en eetlust-onderdrukking, wat versterkt zal worden door ketogene aminozuren. $\mathrm{Er}$ is geen bewijs gevonden voor de hypothese dat eiwit-geïnduceerde verzadiging wordt veroorzaakt door (an)orexigene hormonen. Met betrekking tot het effect van eiwitten op energiegebruik wordt geconcludeerd dat een hoog-eiwit dieet het energiegebruik verhoogt ongeacht de andere macronutriënten in het dieet. De stijging in het energiegebruik wordt voor bijna $50 \%$ verklaard door een verhoogde gluconeogenese. Deze waarnemingen en verklaringen vergroten de kennis over de manier waarop metabole targets worden gestimuleerd door eiwitten uit de voeding en hoe dit bijdraagt aan gewichtsverlies en gewichtsbehoud. 
Dankwoord 

Dank aan iedereen die heeft bijgedragen aan de totstandkoming van dit proefschrift.

Allereerst mijn beide promotoren, Margriet Westerterp-Plantenga en Klaas Westerterp. Margriet, bedankt voor je kritische blik en de snelheid waarmee je ingeleverde stukken van commentaar voorzag. Ik waardeer het heel erg dat je altijd, waar ook ter wereld, tijd vrijmaakt voor je aio's. Bedankt ook voor de kansen die je me gegeven hebt, bijvoorbeeld dat ik veel congressen in het buitenland heb kunnen bezoeken. Klaas, bedankt voor het delen van je kennis over het meten van energiegebruik en het gebruik van stabiele isotopen. Ik ben blij dat ik deze technieken heb kunnen leren en gebruiken. Met je efficiënte en daadkrachtige manier van werken heb je de voortgang van het uitvoeren van de studies en het schrijven van manuscripten altijd in het oog gehouden, wat ik erg waardeer.

Vervolgens wil ik de beoordelingscommissie, bestaande uit prof. dr. A. Schols, prof. dr. J. van Goudoever, prof. dr. W. Lamers, prof. dr. A. Masclee en prof. dr. D. Tomé, bedanken voor hun kritische evaluatie van dit proefschrift.

Dit proefschrift is onderdeel van het project A-012 van het Top Institute Food and Nutrition. Ik wil dan ook de (oud-)projectteamleden (en tevens co-auteurs) Arie Nieuwenhuizen, Robert-Jan Brummer, Mariëlle Engelen en Mick Deutz bedanken. Jullie hebben allemaal vanuit jullie eigen invalshoek een bijdrage geleverd aan de ideeën, opzet en uitvoering van de studies. Arie, bedankt ook dat ik altijd even kon binnenlopen om iets te vragen.

Zonder de praktische bijdrage van verschillende mensen was het me niet gelukt de studies uit te voeren en data te verzamelen. De eerste studies heb ik gedaan in nauwe samenwerking met Ananda, samen hebben we talloze ontbijten uitgedeeld en bloedmonsters verzameld. Paul Schoffelen, bedankt voor je hulp rond de respiratiekamers. Loek Wouters, bedankt voor het uitvoeren van de deuterium analyses en het meedenken over de deuterium isotopen. Jullie beiden ook dank voor de acute hulp bij computerproblemen. Jos, Wendy, Hasibe en Martine bedankt voor alle analyses die jullie gedaan hebben. En natuurlijk ook voor het beantwoorden van al mijn vragen over chemicaliën, de SpeedVac of andere lab-apparatuur tijdens mijn eigen avonturen in het lab. Daarvoor ben ik ook dank verschuldigd aan Mariëtte Ackermans en An Ruiter van het Laboratorium voor Endocrinologie en Radiochemie van het Academisch Medisch Centrum Amsterdam. Dankzij jullie hulp bij de opzet en analyse van het stabiele isotopengedeelte hebben we de gluconeogenese-studie kunnen uitvoeren en heb ik veel geleerd over lab-werk.

Zonder de stagiaires die voor kortere of langere tijd geholpen hebben bij de experimenten zou ik nog lang niet klaar geweest zijn. Ik ga geen namen noemen omdat ik bang ben dat ik misschien iemand vergeet, maar ik wil jullie allemaal bedanken voor jullie hulp.

Daarnaast dank ik mijn (oud)collega's van de $3^{\mathrm{e}}$ verdieping: Natalie, Annemiek, Neeltje, Manuela, Kristel, Mirjam, Caroline, Andrea, Helene, Isolde, Freeha, Astrid, Hanneke, Marcel, Alberto, Ananda, Sanne, Jurriaan, Mieke, Sofie, Stijn en Femke voor hun hulp (in de vroege ochtend) bij het plaatsen van een infuus, de bloedafnames en de fietstesten, maar vooral voor de prettige werksfeer en de gezellige koffie/thee pauzes.

Dan zijn er nog 2 collega's die ik niet genoemd heb: mijn kamergenoten en paranimfen Rick en Anneke. Rick, met jou als kamergenoot is er aan humor geen gebrek. De grappen die je uithaalt zorgen op onze kamer voor de nodige voor- en napret. Maar dat is niet het enige. Ondertussen heb je in korte tijd al een heel aantal manuscripten geschreven en reis je de wereld rond om presentaties te geven over groene thee. Ik ben blij dat je mijn paranimf wilt zijn. 
Anneke, ik vind het heel bijzonder dat wij samen ons feestje kunnen vieren! Ik waardeer je enthousiasme, optimisme en doorzettingsvermogen enorm. Jouw gezelligheid, maar ook de inhoudelijke discussies die we hadden, vond ik altijd erg prettig en zal ik gaan missen. Veel succes met je nieuwe baan!

Voor de totstandkoming van dit proefschrift was ontspanning op z'n tijd natuurlijk ook nodig. Alle vriendinnen en vrienden, waaronder 'de meiden van het Kruisheren', het Vierkant, de Thymossers en de oud-WaHo-ers, bedankt voor de dagjes/weekendjes weg, de feestjes en het gezellige kletsen. Dank ook aan mijn fietsmaatjes voor de inspannende maar toch ontspannende tochtjes.

Rinus, Anne en Jeroen bedankt voor jullie belangstelling voor mijn onderzoek, maar vooral ook de andere kijk erop (tijdens discussies over de verschillen tussen varkens en mensen of het gezonder maken van chocoladerepen). Ik hoop dat we ook in de toekomst, ondanks dat we misschien niet dicht bij elkaar in de buurt wonen, regelmatig samen een kop koffie drinken en discussiëren over vanalles en nog wat. Veel succes met jullie bezigheden; werk, promotieonderzoek of studie.

Pa en ma, bedankt dat jullie me hebben geleerd en me altijd de kans hebben gegeven om mijn eigen keuzes te maken. Jullie staan altijd voor me klaar met een luisterend oor of een helpende hand. Dankzij jullie steun en vertrouwen is het me gelukt! 
List of publications 



\section{AS FIRST AUTHOR}

- Veldhorst MAB, Smeets AJPG, Soenen S, Hochstenbach-Waelen A, Hursel R, Diepvens K, Lejeune MPGM, Luscombe-Marsh ND, Westerterp-Plantenga MS. Protein-induced satiety: Effects and mechanisms of different proteins. Physiol Behav 2008; 94: 300-307

- Veldhorst MAB, Nieuwenhuizen AG, Hochstenbach-Waelen A, Westerterp KR, Engelen MPKJ, Brummer RJM, Deutz NEP, Westerterp-Plantenga MS. Comparison of the effects of a high- and normal-casein breakfast on satiety, 'satiety' hormones, plasma amino acids and subsequent energy intake. Br J Nutr 2009; 101 (2): 295-303

- Veldhorst MAB, Nieuwenhuizen AG, Hochstenbach-Waelen A, Westerterp KR, Engelen MPKJ, Brummer RJM, Deutz NEP, Westerterp-Plantenga MS. Effects of complete wheyprotein breakfasts versus whey without GMP breakfasts on energy intake and satiety. Appetite 2009; 52 (2): 388-395

- Veldhorst MAB, Nieuwenhuizen AG, Hochstenbach-Waelen A, Westerterp KR, Engelen MPKJ, Brummer RJM, Deutz NEP, Westerterp-Plantenga MS. Effects of high and normal soyprotein breakfasts on satiety and subsequent energy intake, including amino acid and 'satiety' hormone responses. Eur J Nutr 2009; 48 (2): 92-100

- Veldhorst MAB, Nieuwenhuizen AG, Hochstenbach-Waelen A, Westerterp KR, Engelen MPKJ, Brummer RJM, Deutz NEP, Westerterp-Plantenga MS. A breakfast with alphalactalbumin, gelatin, or gelatin+TRP lowers energy intake at lunch compared with a breakfast with casein, soy, whey, or whey-GMP. Clin Nutr 2009; 28 (2): 147-155

- Veldhorst MAB, Nieuwenhuizen AG, Hochstenbach-Waelen A, van Vught JAH, Westerterp KR, Engelen MPKJ, Brummer RJM, Deutz NEP, Westerterp-Plantenga MS. Dose-dependent satiating effect of whey relative to casein or soy. Physiol Behav. 2009; 96 (4-5): 675-682

- Veldhorst MAB, Westerterp-Plantenga MS, Westerterp KR. Gluconeogenesis and energy expenditure after a high protein, carbohydrate-free diet. Am J Clin Nutr 2009; 90: 519-526

- Veldhorst MAB, Westerterp KR, van Vught JAH, Westerterp-Plantenga MS. Protein-induced appetite suppression is affected by the presence or absence of carbohydrates. Submitted for publication 2009

\section{AS CO-AUTHOR}

- den Hoed M, Smeets AJ, Veldhorst MA, Nieuwenhuizen AG, Bouwman FG, Heideman AG, Mariman EC, Westerterp-Plantenga MS, Westerterp KR. SNP analyses of postprandial responses in (an)orexigenic hormones and feelings of hunger reveal long-term physiological adaptations to facilitate homeostasis. Int J Obes 2008; 32 (12): 1790-1798

- Nieuwenhuizen A, Hochstenbach-Waelen A, Veldhorst M, Westerterp K, Engelen $M$, Brummer RJ, Deutz N, Westerterp-Plantenga M. Acute effects of breakfasts containing alpha-lactalbumin, or gelatin with or without added tryptophan, on hunger, 'satiety' hormones and amino acid profiles. Br J Nutr 2009; 101 (12): 1859-1866 
- Hochstenbach-Waelen A, Veldhorst MA, Nieuwenhuizen AG, Westerterp-Plantenga MS, Westerterp KR. Comparison of 2 diets with either $25 \%$ or $10 \%$ of energy as casein on energy expenditure, substrate balance, and appetite profile. Am J Clin Nutr 2009; 89 (3): 831-838

- van Vught JAH, Heitmann BL, Nieuwenhuizen AG, Veldhorst MA, Brummer RJM, Westerterp-Plantenga MS. Association between dietary protein intake and 6y-change in body composition among children (EYHS). Clin Nutr 2009; in press

- van Vught JAH, Heitmann BL, Nieuwenhuizen AG, Veldhorst MA, Brummer RJM, Westerterp-Plantenga MS. Association between dietary protein intake and 3y-change in growth in height and width among children (CoSCIS). Publ Heath Nutr 2009; in press

- $\quad$ van Vught JAH, Nieuwenhuizen AG, Veldhorst MA, Gerver WJ, Brummer RJM, WesterterpPlantenga MS. Review: Pharmacological and physiological tests to predict successful GHtherapy. J Pediatr Endocrinol Metab 2009; in press

- $\quad$ van Vught JAH, Nieuwenhuizen AG, Veldhorst MA, Brummer RJM, Westerterp-Plantenga MS. Somatotropic effects of protein in relation to the presence of other macronutrients. eSPEN journal 2009; in press

- Hochstenbach-Waelen A, Veldhorst MAB, Nieuwenhuizen AG, Westerterp-Plantenga MS, Westerterp KR. Effects of gelatin in a 25 vs 10 energy\% single protein diet on energy expenditure, substrate balances and appetite. In revision 2009

- Hochstenbach-Waelen A, Westerterp-Plantenga MS Veldhorst MAB, Westerterp KR. Single protein casein and gelatin diets affect energy expenditure similarly, but substrate balance and appetite differentially. In revision 2009

- $\quad$ van Vught JAH, Nieuwenhuizen AG, Veldhorst MA, Brummer RJM, Westerterp-Plantenga MS. Somatotripic responses of soy, gelatin, alpha lactalbumin and milk. In revision 2009

- $\quad$ van Vught JAH, Nieuwenhuizen AG, Veldhorst MA, Brummer RJM, Westerterp-Plantenga MS. Acute ingestion of gelatin protein normalizes blunted GH concentrations in visceral obesity. Submitted for publication 2009

\section{PATENT}

Nieuwenhuizen AG, Westerterp KR, Hochstenbach-Waelen A, Brummer RJM, Mela DJ, Westerterp-Plantenga MS, Veldhorst MAB. Food compositions. WO 2009008714 (A1)

\section{CHAPTER BOOK}

Veldhorst MAB, van Vught JAH, Westerterp-Plantenga MS. The effects of casein-, whey-, and soy protein on satiety, energy expenditure, and body composition. In: Cho $S$ editor. Weight control and slimming ingredients, Wiley and Blackwell Publishing, In press 2009

\section{PRESENTATIONS}

- Veldhorst MAB, Nieuwenhuizen AG, Hochstenbach-Waelen A, Westerterp KR, Engelen MPKJ, Brummer RJM, Deutz NEP, Westerterp-Plantenga MS. Effects of high or normal casein-, soy-, or whey with or without GMP- protein breakfasts on satiety, 'satiety' 
hormones, and plasma amino acid responses. Annual meeting of Society of the Study of Ingestive Behavior, July 2007, Steamboat Springs (Appetite 2007; 49 (1): 336)

Veldhorst $M$, Nieuwenhuizen A, Hochstenbach-Waelen A, Westerterp K, Engelen $M$, Brummer RJ, Deutz N, Westerterp-Plantenga M. Effects of high and normal casein-, soy-, and whey-protein breakfasts on amino acid, satiety, and 'satiety' hormone responses \& Veldhorst $M$, Nieuwenhuizen A, Hochstenbach-Waelen A, Westerterp K, Engelen $M$, Brummer RJ, Deutz N, Westerterp-Plantenga M. Effects of casein-, soy-, whey with or without GMP-, alpha-lactalbumin-, or gelatin with or without added tryptophan- protein breakfasts on energy intake. European Congress on Obesity, May 2008, Geneva (Int J Obes 2008; 32 (suppl 1): S146 \& Int J Obes 2008; 32 (suppl 1): S142)

- Veldhorst $M$, Nieuwenhuizen A, Hochstenbach-Waelen A, Westerterp K, Engelen $M$, Brummer RJ, Deutz N, Westerterp-Plantenga M. Effects of casein-, soy-, whey with or without GMP-, alpha-lactalbumin-, or gelatin with or without added tryptophan- protein breakfasts on energy intake. Annual meeting of the Society of the Study of Ingestive Behavior, July 2008, Paris (Appetite 2008; 51 (suppl 2): 408)

- Veldhorst M, Nieuwenhuizen A, Hochstenbach-Waelen A, Westerterp K, Engelen $M$, Brummer RJ, Deutz N, Westerterp-Plantenga M. A breakfast with $\alpha$-lactalbumin, gelatin, or gelatin+TRP lowers energy intake compared with a breakfast with casein, soy, whey, or whey-GMP. Annual meeting of the European Society of Parenteral and Enteral Nutrition, September 2008, Florence (Clin Nutr 2008; 3 (suppl 1): 183)

- Veldhorst M. The role of neuropeptides in the control of energy intake and energy expenditure. Winter Neuropeptides Conference, February 2009, Breckenridge

- Veldhorst M, Westerterp-Plantenga M, Westerterp K. Gluconeogenesis and energy expenditure after a high protein, carbohydrate-free diet. European Congress on Obesity, May 2009, Amsterdam

- Veldhorst MAB, Westerterp KR, van Vught JAH, Westerterp-Plantenga MS. Effects of dietary fat oxidation on appetite at high protein diets. Benjamin Franklin Lafayette Symphagium, June 2009, Fréjus

- Veldhorst M, Westerterp-Plantenga M, Westerterp K. Gluconeogenesis and energy expenditure after a high protein, carbohydrate-free diet. Annual meeting of the Society of the Study of Ingestive Behavior, July 2009, Portland (Appetite 2009; 52 (3): 862) 

Curriculum Vitae 

Margriet Veldhorst was born on September $26^{\text {th }} 1981$ in Boekel, the Netherlands. After she completed secondary school at the Kruisheren Kollege in Uden in 1999 she started the study Nutrition and health at Wageningen University. In 2002-2003 she had a full-time position as treasurer in the Daily Board of the Sportsfoundation of Wageningen University (SWU Thymos). Afterwards she continued her study with the master's programme with two specializations: Human nutrition and Human and animal physiology. Moreover, she performed an internship at Numico Research. In March 2005 she obtained her master's degree.

In June 2005 she started working as a PhD-student at the department of Human biology of Maastricht University under supervision of prof. dr. M. Westerterp-Plantenga and prof. dr. K. Westerterp. Her research was part of the project 'The role of dietary protein in satiety and weight management' of the Top Institute Food and Nutrition. In July 2007 she was awarded with a New Investigator Award at the annual meeting of the Society of the Study of Ingestive Behavior in Steamboat Springs, United States of America.

In September 2009 she started working as a post-doc at the department of Pediatrics of the Erasmus Medical Center/Sophia in Rotterdam. 






